\title{
KATALOG RUBRYCEL I SCHEMATYZMÓW ZAKONÓW MĘSKICH I ŻEŃSKICH Z OBSZARU HISTORYCZNYCH ZIEM RZECZYPOSPOLITEJ ZA LATA 1690-2008 W ZBIORZE BIBLIO- TEKI UNIWERSYTECKIEJ KATOLICKIEGO UNIWERSYTETU LUBELSKIEGO JANA PAWLA II
}

Zbiory Biblioteki Uniwersyteckiej Katolickiego Uniwersytetu Lubelskiego (dalej BU KUL) w znacznej mierze odzwierciedlają główny, teologiczno-filozoficzny kierunek kształcenia na nim podejmowany. Bogata baza biblioteczna obejmuje nie tylko literaturę o tematyce teologicznej, ale również różnorodne kościelne druki urzędowe, do których zaliczane są zarówno rubrycele, jak i schematyzmy. Od lat 70. i 80. XX wieku, kiedy rubrycelami i schematyzmami zajmowali się w różnych aspektach głównie historycy związani z KUL, w polskiej literaturze przedmiotu przez dłuższy czas nie notowało się nowych opracowań. Liczba publikacji na ich temat jest dość skąpa, a do najobszerniejszych tekstów należą prace ks. Stanisława Librowskiego oraz ks. Tadeusza Krahela ${ }^{1}$. W nich też znajduje się

\footnotetext{
* Edyta Chomentowska - lic. historii, mgr administracji, dokumentalista w Ośrodku Badań nad Geografią Historyczną Kościoła w Polsce KUL.

${ }^{1}$ S. Librowski, Katalog rubrycel i schematyzmów diecezji i zakonów historycznej Polski znajdujacych się w księgozbiorze podręcznym Archiwum Diecezjalnego we Włocławku. cz. 1, z. 1, „Archiwa Biblioteki i Muzea Kościelne" (dalej: ABMK), 23 (1971) s. 213-310; tenże, Katalog rubrycel i schematyzmów diecezji i zakonów historycznej Polski znajdujących się w księgozbiorze podręcznym Archiwum Diecezjalnego we Włocławku. cz. 1, z. 2, ABMK, 24 (1972) s. 5-94; tenże, Katalog rubrycel i schematyzmów diecezji i zakonów historycznej Polski znajdujących się w księgozbiorze podręcznym Archiwum Diecezjalnego we Włocławku. cz. 1. z. 3, ABMK, 25 (1972) s. 39-113; tenże, Katalog rubrycel i schematyzmów diecezji i zakonów historycznej Polski znajdujących się w księgozbiorze podręcznym Archiwum Diecezjalnego we Włocławku. cz. 1, z. 4, ABMK, 26 (1973) s. 889197; tenże, Katalog rubrycel i schematyzmów diecezji i zakonów historycznej Polski znajdujących się w księgozbiorze podręcznym Archiwum Diecezjalnego we Włocławku. cz. 2, ABMK, 27 (1973) s. 57-130; T. Krahel, Schematyzmy diecezji wileńskiej jako źródto historyczne, ABMK, 38 (1979) cz. 1, s. 111-149; 39 (1979) s. 191-233.
} 
omówienie najważniejszej literatury ${ }^{2}$. Rubrycele (kalendarze liturgiczne, directorium, ordo) zawierające przepisy i wskazania dotyczące odprawiania Mszy św. i odmawiania brewiarza są zaliczane do ksiąg ceremonialnych ${ }^{3}$. Wydawane były od XVII wieku, jednak kształtowały się już od początków chrześcijaństwa, a najstarsze zabytki pochodzą z IV-V wieku ${ }^{4}$. Początkowo były one dołączane do ksiąg liturgicznych, przede wszystkim mszałów i brewiarzy, a dzięki rozwojowi druku zaistniały jako samodzielne tytuły. Schematyzmy (schematismus, catalogus, elenchus) natomiast są wykazami osobowymi duchowieństwa określonej diecezji lub prowincji zakonnej. Schematyzmy stały się popularne w XVII wieku a w formie drukowanej pojawiły się w XVIII wieku ${ }^{5}$. Zazwyczaj zawierają też dodatkowe informacje, których zakres zależy często od inwencji ich autorów. Mogą więc dotyczyć obsady personalnej poszczególnych urzędów, historii jednostki administracji kościelnej, liczby wiernych w parafii i innych.

Schematyzmy jako źródło historyczne, wykorzystywane są przez historyków między innymi do celów statystycznych czy biograficznych. Najczęściej jednak podstawą rozważań stają się wiadomości zawarte w schematyzmach diecezjalnych w odniesieniu do zagadnień dotyczących administracji kościelnej oraz prozopografii duchowieństwa ${ }^{6}$. Niemniej coraz częściej schematyzmy stają się same w sobie przedmiotem badań, jako źródła historyczne ${ }^{7}$. Mimo wielokrotnych postulatów badawczych nie podjęto całościowych prac nad wieloaspektowym opra-

${ }^{2}$ Zob. omówienie literatury oraz wykaz najważniejszych publikacji, S. Librowski, Katalog rubrycel i schematyzmów. cz. 1. z. 1, ABMK, 23 (1971) s. 225; Krahel, Schematyzmy diecezji wileńskiej, s. 120-121.

${ }^{3}$ A. Nowowiejski, Wykład liturgii Kościoła katolickiego, t. 2, Płock 1905, s. 152.

${ }^{4}$ H. Wąsowicz, Kalendarz chrześcijański, w: Kalendarze, red. E. Gigilewicz, Lublin 2005, s. 68.

${ }^{5}$ A. Bieś, L. Grzebień, M. Inglot, Polonica w Archiwum Rzymskim Towarzystwa Jezusowego, t. 1: Polonia, Kraków 2002, s. 45.

${ }^{6}$ Zob. np. J. Kumor-Mielnik, Sieć dekanalna i parafialna (archi)diecezji lubelskiej $w$ latach 1805-2005, Lublin 2011; J. Królikowski, Wstępne sprawozdanie z prac nad dziedzictwem po klasztorach skasowanych na obszarze diecezji tarnowskiej, „Hereditas Monasteriorum”, 1 (2012) s. 411412; Atlas historyczny (archi)diecezji lubelskiej 1805-2010, red. H. Gapski, Lublin 2011.

7 Е. Хоментовська, Друковані чернечі рубрицелі і шематизми у фондах Бібліотеки Католицько Університету Івана Павла ІІ в Любліні. Вибрані питання, „Visnyk Lviv Univ.” Ser. Bibliol. Libr. Stud. Inform. Techn., Is. 5 (2010), s. 76-84; Е. Хоментовська, Структура $і$ фонди незмінних інформацій, які знаходяться в друкованих монастирських схематизмах на прикладі єзуїсських каталогів з 1918-1939 рр., w: Софійсъкі Читання. Матеріали V міжнародної науково-практичної конференції ,Духовний потенціал та історичний контекст християнсъкого мистеитва" (м. Київ, 28-29 травня 2009 р), Київ 2010, s. 396-406; Е. Chomentowska, Zasób informacji zawartych $w$ katalogach prowincji jezuickich z lat 1914-39 na podstawie zbioru Biblioteki Uniwersyteckiej Katolickiego Uniwersytetu Lubelskiego, w: Narrata de fontibus hausta. Studia nad problematyka kościelna, polityczna i archiwistyczna ofiarowane Janowi Skarbkowi w siedemdziesiąta rocznicę urodzin, red. A. Barańska, W. Matwiejczyk, Lublin 2010, s. 917-936; A. Kwaśniewski, Katalog rubrycel i schematyzmów polskich cystersów znajdujących się w księgozbiorze podręcznym Archiwum Diecezjalnego w Kielcach (1788-1816), „Hereditas Monasteriorum", 1 (2012) s. 189-205. 
cowaniem tego rodzaju źródeł. W tym miejscu zaznaczyć należy, iż choć prace ks. S. Librowskiego i ks. T. Krahela zawierają obszerne analizy powstania, rozwoju oraz funkcjonowania rubrycel i schematyzmów, to niektóre ustalenia w nich zawarte powinny zostać poddane weryfikacji. Dotyczy to przede wszystkim druków zakonnych, gdyż wysnute w nich wnioski odnoszą się jedynie do ograniczonej liczby druków stanowiących zasób Biblioteki Seminarium Duchownego we Włocławku.

Sama koncepcja sporządzenia katalogu tego typu źródeł przechowywanych w BU KUL jest nawiązaniem do działań podjętych przez ks. S. Librowskiego, który jako pierwszy opracował rubrycele i schematyzmy w księgozbiorze Archiwum Diecezjalnego we Włocławku. Przy tej okazji wysunął on postulat, by w podobny sposób dokonać spisu wszystkich druków tego rodzaju, jakie ukazały się na ziemiach polskich ${ }^{8}$.

Księgozbiór kalendarzy i schematyzmów zarówno diecezjalnych, jak i zakonnych BU KUL liczy ponad 4.500 tytułów (bardzo rzadko, ale zdarzają się dublety). Oznacza to tym samym, iż liczy około 2.500 roczników więcej niż posiada zasób Archiwum Diecezjalnego we Włocławku9 . Na kształt zbioru największy wpływ wywarły zakupy poszczególnych woluminów, ale także darowizny, które pochodzą m.in. z Biblioteki Uniwersytetu Jagiellońskiego (głównie druki paulińskie), Uniwersytetu Marii Curie-Skłodowskiej w Lublinie czy Archiwum Diecezjalnego we Włocławku. Z bibliotek tych najczęściej przekazywano dublety, dlatego też w księgozbiorze BU KUL znalazły się tylko niektóre roczniki. Nie umniejsza to mimo wszystko jego rangi na tle ogólnopolskich zbiorów dla tego typu wydawnictw. Już wstępna analiza poświadcza fakt, iż zbiór rubrycel i schematyzmów BU KUL jest jednym z najbogatszych tego typu wśród polskich bibliotek naukowych. Pod względem liczby dziewiętnastowiecznych druków tego rodzaju jest on porównywalny do zasobów Biblioteki Uniwersytetu Jagiellońskiego, Biblioteki Uniwersytetu Warszawskiego, Biblioteki Książąt Czartoryskich w Krakowie czy Zakładu Narodowego im. Ossolińskich we Wrocławiu. Znaczenie księgozbioru jest natomiast nieocenione w stosunku do roczników pochodzących z XX wieku zwłaszcza wydanych po 1945 r., gdyż w bibliotekach naukowych trudno doszukać się roczników z tego okresu. Szczególne miejsce biblioteka lubelska zajmuje także na tle agend diecezjalnych i zakonnych (bibliotek seminaryjnych, zakonnych oraz archiwów). Zbiory ich są może bardziej kompletne, jednak ich zasób obejmuje zazwyczaj druki dotyczące określonej jednostki administracji kościelnej bądź zakonnej, najczęściej diecezji lub prowincji.

Co do organizacji księgozbioru bibliotecznego, rubrycele oraz schematyzmy traktowane są jako druki periodyczne, zaliczane do działu czasopism i umieszczane właśnie w tego rodzaju katalogach bibliotecznych (kartkowych bądź coraz częściej komputerowych). Takie rozwiązanie ma miejsce również w BU KUL, gdzie wydawnictw tych należy szukać przede wszystkim w katalogu alfabetycznym czasopism pod hasłem Ordo oraz Schematismus, a wydawanych po 1995 r.

\footnotetext{
${ }^{8}$ Librowski, Katalog rubrycel i schematyzmów. cz. 1, z. 1, s. 225-226.

${ }^{9}$ Tamże, s. 222.
} 
w katalogu komputerowym. Kilka najstarszych druków sprzed 1800 r. przechowywanych jest w Czytelni Starych Druków, która posiada własny, wyodrębniony katalog czasopism.

Badając cały zasób rubrycel i schematyzmów znajdujących się w BU KUL, zasadnym wydało się podzielenie go na 2 części, a z kolei w każdej z nich wyodrębnienie dwóch grup:

Część I. Wydawnictwa diecezjalne

1. Rubrycele i schematyzmy poszczególnych diecezji polskich

2. Rubrycele i schematyzmy diecezji zagranicznych

Część II. Wydawnictwa zakonne

1. Rubrycele i schematyzmy prowincji zakonów męskich i żeńskich istniejących na ziemiach polskich

2. Rubrycele i schematyzmy prowincji zakonów męskich i żeńskich spoza terenu Rzeczypospolitej

Przedmiotem opracowania w pierwszej kolejności stały się druki części dotyczącej zakonów a dokładniej jej pierwszej grupy. Obejmuje ona zakony o średniowiecznej proweniencji oraz zgromadzenia zakonne sprowadzone bądź powstałe na ziemiach polskich dopiero w XIX-XX wieku. Pamiętać należy, iż prowincje czy też inne, odpowiadające im jednostki organizacyjne są związkiem osób, a nie określonym terytorium ${ }^{10}$. Stąd też, choć większość roczników dotyczy prowincji na historycznych terenach Rzeczypospolitej, to zdarzają się w Katalogu tytuły obejmujące wykazy zakonników i zakonnic mieszkających poza jej obszarem, ale związanych ze zgromadzeniami w Polsce ${ }^{11}$. Ponadto ujęto w nim również te druki, które zostały wydane przez prowincje zakonne spoza terenu Rzeczypospolitej, ale obejmujące klasztory położone na obszarze Śląska mając na uwadze jego historycznie związki z Polską. Rozwiązanie to dotyczy przede wszystkim zakonu bonifratrów i jego prowincji prusko-śląskiej oraz boromeuszek prowincji śląskiej.

Zakres chronologiczny Katalogu obejmujący lata 1690-2008 wskazuje na rok, na który został wydany najstarszy i najnowszy druk znajdujący się w zbiorach biblioteki. Omawiane wydawnictwa zakonne w zasobie BU KUL w niewielkim stopniu dotyczą okresu przedrozbiorowego. Liczba kalendarzy wyodrębnionych jako stare druki (sprzed 1800 r.) wynosi pięć roczników i reprezentowana jest przez wydawnictwa: augustianów - trzy egzemplarze (z 1777, 1789, 1790 r.), kapucynów (1781 r.) i dominikanów. Rubrycela ostatniego z wymienionych zakonów wydana na rok 1690 jest jednocześnie najstarszym woluminem tego rodzaju w księgozbiorze BU KUL. Odnośnie schematyzmów oprócz druku należącego do

${ }^{10}$ Podręczna encyklopedia instytutów życia konsekrowanego, M. Daniluk, K. Klauza, Lublin 1994, s. 238: Prowincja zakonna.

${ }^{11}$ Należy do nich schematyzm Towarzystwa Chrystusowego dla Polonii Zagranicznej (chrystusowców) sporządzony dla domów w Ameryce Południowej (Towarzystwo Chrystusowe w Ameryce Południowej 1958-1988, oprac. Bernard Kołodziej, [Curtiba 1987], 96, [1] ss.) czy schematyzmy salezjanów zawierające spisy osób pochodzących z polskich prowincji, ale przebywających poza granicami kraju (np. Elenko. Polska Rodzina Salezjańska poza krajem 1996-1997, Warszawa [1996], 98 ss.). 
jezuitów (niepełny katalog prowincji polskiej z 1742 r.) najstarsze pochodzą dopiero z XIX wieku i są to pojedyncze egzemplarze paulińskie (z 1811 i 1828 r.) oraz pijarski (1825 r.).

Odnośnie wydawnictw zakonów działających na historycznych ziemiach Rzeczypospolitej ich liczba wynosi ogółem 628 (w archiwum włocławskim jest 307 roczników $^{12}$ ) z której to 600 roczników dotyczy zakonów męskich ${ }^{13}$. Znacznie mniej, bo jedynie 28 roczników powstało wyłącznie dla zakonów żeńskich. Pamiętać należy, iż w przypadku, gdy zakon posiadał gałąź żeńską, wykazy sióstr najczęściej notowane były w schematyzmach Pierwszego Zakonu. Praktyka taka dotyczy głównie bernardynek (druki bernardynów) dominikanek (druki dominikanów), klarysek (druki franciszkanów konwentualnych) czy augustianek. Ostatnie $\mathrm{z}$ nich co prawda posiadają dwa samodzielne tytuły, ale w pozostałych latach ich wykazy dodawane były do roczników augustianów. Poniżej, w tabeli 1 i 2 zestawiono druki według zakonów, co umożliwia określenie liczby poszczególnych ich rodzajów według zakonów.

Tabela nr 1. Liczba rubrycel i schematyzmów zakonów męskich z obszaru historycznych ziem Rzeczypospolitej z lat 1690-2008 znajdujących się w zasobie BU KUL

\begin{tabular}{|c|c|c|c|c|c|c|}
\hline Lp. & Nazwa zakonu & $\begin{array}{l}\text { Liczba } \\
\text { rubrycel }\end{array}$ & $\begin{array}{c}\text { Liczba } \\
\text { schematyzmów }\end{array}$ & $\begin{array}{c}\text { Liczba } \\
\text { polączonych } \\
\text { rubrycel } \\
\text { i } \\
\text { schematyzmów }\end{array}$ & $\begin{array}{c}\text { Razem } \\
\text { dostępnych } \\
\text { w zbiorach } \\
\text { BU KUL }\end{array}$ & $\begin{array}{c}\text { Liczba } \\
\text { brakujących } \\
\text { druków* }\end{array}$ \\
\hline 1. & augustianie & 26 & 6 & 36 & 69 & 4 \\
\hline 2. & bazylianie & - & 26 & - & 26 & - \\
\hline 3. & bernardyni & 31 & 51 & 4 & 86 & 3 \\
\hline 4. & bonifratrzy & - & 4 & - & 4 & - \\
\hline 5. & chrystusowcy & - & 1 & - & 1 & - \\
\hline 6. & dominikanie & 10 & 16 & 3 & 29 & 1 \\
\hline 7. & filipini & - & 2 & - & 2 & 1 \\
\hline 8. & $\begin{array}{l}\text { franciszkanie } \\
\text { konwentualni }\end{array}$ & 41 & 9 & 2 & 52 & - \\
\hline 9. & jezuici & 46 & 102 & - & 148 & 2 \\
\hline 10. & kapucyni & 14 & 10 & 4 & 28 & - \\
\hline 11. & karmelici & 2 & 9 & 1 & 12 & - \\
\hline 12. & karmelici bosi & 30 & 1 & - & 31 & - \\
\hline 13. & misjonarze & 1 & 6 & - & 7 & 3 \\
\hline
\end{tabular}

${ }^{12}$ Librowski, Katalog rubrycel i schematyzmów. cz.2, s. 59.

${ }^{13}$ Analiza zasobu kalendarzy i schematyzmów zakonnych w zbiorze BU KUL została przedstawiona podczas Międzynarodowej Konferencji we Lwowie w dniach 16-19 października 2008 r. podczas prac sekcji 1: „Бібліотека як інформаційно-освітній осередок в європейському суспільстві: історичний вимір" i opublikowana w materiałach pokonferencyjnych, zob. Хоментовська, Друковані чернечі рубрииелі, s. 76-84. 


\begin{tabular}{|c|c|c|c|c|c|c|}
\hline 14. & pallotyni & 13 & 4 & - & 17 & 1 \\
\hline 15. & paulini & 20 & 6 & 33 & 58 & 8 \\
\hline 16. & pijarzy & 1 & 2 & - & 3 & - \\
\hline 17. & reformaci & 8 & 13 & 4 & 25 & 1 \\
\hline 18. & salwatorianie & - & 1 & - & 1 & - \\
\hline 19. & sercanie & 1 & 1 & - & 2 & - \\
\hline & Ogólem & $\mathbf{2 4 4}$ & $\mathbf{2 7 0}$ & $\mathbf{8 7}$ & $\mathbf{6 0 1}$ & $\mathbf{2 4}$ \\
\hline
\end{tabular}

*Liczba brakujących egzemplarzy ustalona została na podstawie porównania stanu faktycznego z opisami druków w katalogu kartkowym i komputerowym.

Tabela nr 2. Liczba kalendarzy i schematyzmów zakonów żeńskich z dawnych ziem Rzeczypospolitej z lat 1830-1939 znajdujących się w zasobie BU KUL

\begin{tabular}{|c|c|c|c|c|c|c|}
\hline Lp. & Nazwa zakonu & $\begin{array}{c}\text { Liczba } \\
\text { rubrycel }\end{array}$ & $\begin{array}{c}\text { Liczba } \\
\text { schematyzmów }\end{array}$ & $\begin{array}{c}\text { Liczba } \\
\text { polączonych } \\
\text { rubrycel } \\
\text { i schematyzmów }\end{array}$ & $\begin{array}{c}\text { Razem } \\
\text { dostępnych } \\
\text { w zbiorach } \\
\text { BU KUL }\end{array}$ & $\begin{array}{c}\text { Liczba } \\
\text { brakujących } \\
\text { druków* }\end{array}$ \\
\hline 1. & augustianki & - & 2 & - & 2 & - \\
\hline 2. & norbertanki & 1 & - & 21 & 22 & - \\
\hline 3. & urszulanki UR & - & 1 & - & 1 & 1 \\
\hline 4. & $\begin{array}{c}\text { służebniczki } \\
\text { starowiejskie }\end{array}$ & - & 1 & - & 1 & 1 \\
\hline 5. & boromeuszki & - & 2 & - & 2 & - \\
\hline & Ogólem & $\mathbf{1}$ & $\mathbf{6}$ & $\mathbf{2 1}$ & $\mathbf{2 8}$ & $\mathbf{2}$ \\
\hline
\end{tabular}

* Liczba brakujących egzemplarzy ustalona została na podstawie porównania stanu faktycznego z opisami druków w katalogu kartkowym i komputerowym

Z tabel wynika, iż w zbiorze BU KUL zakony męskie posiadają 601 roczników druków, w tym 244 samodzielnych rubrycel, zaś schematyzmów 270. Wartości te należy powiększyć o 87 roczników obejmujących oba te druki wspólnie. Tym samym liczba rubrycel wzrośnie do 330, a liczba katalogów do 356. W przypadku zakonów żeńskich ogólna liczba druków, jak wspomniano wynosi 28. Wśród nich najwięcej, bo 21 roczników to połączone rubrycele i schematyzmy, pozostałe zaś to 6 schematyzmów i 1 kalendarz. Jednocześnie stwierdzono ogółem brak 28 roczników wymienionych w katalogach bibliotecznych, z tego 26 druków dotyczy zakonów męskich i 2 zakonów żeńskich.

Językiem używanym przy tworzeniu kalendarzy oraz schematyzmów była łacina, którą stosowano przez większość omawianego okresu. W zaborze rosyjskim (przede wszystkim w Królestwie Polskim) przy sporządzaniu tego rodzaju druków w II połowie XIX wieku (zwłaszcza po powstaniu styczniowym) obowiązywał swoisty ,podwójny zapis”. Polegał on na tym, iż część tekstów pisana była po 
łacinie, a część po polsku i/lub po rosyjsku. Oprócz tych wyjątków język polski wprowadzany był stopniowo dopiero od II połowy XX wieku ${ }^{14}$. Z kolei język niemiecki pojawia się w schematyzmach zakonu bonifratrów prowincji pruskośląskiej oraz boromeuszek prowincji śląskiej.

Biorąc pod uwagę stan zachowania poszczególnych egzemplarzy można stwierdzić, że w większości przypadków są w stanie dobrym lub bardzo dobrym. Jedynie w kilku egzemplarzach brak jest kartek, a w kilkunastu opraw. Co do oprawy - najczęściej ocalały oryginalne okładki, pozostałe roczniki zostały odpowiednio zabezpieczone lub oprawione wtórnie. Kalendarze z racji swych funkcji służyć miały tylko rok, dlatego nie wymagano, by oprawa była wysokiej jakości. Część woluminów jednak dla zwiększenia ich przydatności oprawiona została przez ówczesnych introligatorów a tak wykonane okładziny zdobione są nawet złoconymi ornamentami ${ }^{15}$. W schematyzmach znaleźć można niekiedy ilustracje, fotografie lub litografie ${ }^{16}$. Znaczna liczba roczników posiada podpisy lub pieczęci właścicieli umożliwiające dość precyzyjne określenie proweniencji druków. Na marginesie zagadnienia pochodzenia egzemplarzy wskazać należy, iż interfoliowane rubrycele paulińskie $\mathrm{w}$ wielu przypadkach posiadają liczne notatki i prywatne zapiski o różnej tematyce.

\section{Konstrukcja opisu bibliograficznego zastosowanego $w$ Katalogu}

Przy opracowywaniu Katalogu zastosowano w znacznej mierze zasady zawarte w Opisie bibliograficznym wydawnictw ciagtych (interpretacja postanowień PN-N-01152-02) ${ }^{17}$ oraz Projekcie instrukcji wydawniczej dla źródet historycznych $X I X$ i poczatku XX wieku ${ }^{18}$. Kierowano się także ustaleniami oraz przyjęto szablon opisu bibliograficznego zastosowany przez ks. S. Librowskiego. Ewentualne zmiany i odstępstwa przedstawiono poniżej.

Całość materiału bibliograficznego podzielno na dwie części: pierwsza - obejmuje zakony i zgromadzenia męskie, druga - zakony i zgromadzenia żeńskie. Na wewnętrzny układ każdej z części składają się: rozdziały obejmujące poszczególne zakony w kolejności alfabetycznej (według ich nazw powszechnie używanych) oraz podrozdziały. W podrozdziałach starano się usystematyzować jednostki administracji zakonnej poszczególnych zakonów według chronologii ich powstawania.

${ }^{14}$ Np. schematyzm bernardynów - Rocznik Zakonu Braci Mniejszych św. O.N. Franciszka Kapucynów Prowincji Krakowskiej św. Józefa na Rok Jubileuszowy 1950, Kraków [1949], 80 ss.; kalendarze jezuickie od 1969 r. Kalendarz liturgiczny Polskich Prowincji Towarzystwa Jezusowego na rok 1969, oprac. Józef Żukowicz, Kraków [1968], 140 ss., [2] kk.

${ }^{15} \mathrm{~Np}$. Schematismus Ordinis St. Joannis de Deo almae Provinciae Borusso-Silesiacae S. Caroli Borromaei et S. Hedwigis. Anno Domini 1908, Wratislaviae [1907], VII, 41 ss.

${ }^{16} \mathrm{~Np}$. Katalog Warszawskiej Prowincji Braci Mniejszych Kapucynów, [stan z dnia 14 października 1995], [b.m. 1994], 41, [5] ss.

${ }^{17} \mathrm{M}$. Janowska, Opis bibliograficzny wydawnictw ciagtych (interpretacja postanowień $P N-N$ 01152-02), Warszawa 1996, ss. 55.

${ }^{18}$ I. Ihnatowicz, Projekt instrukcji wydawniczej dla źródel historycznych XIX i początku XX wieku, „Studia Źródłoznawcze”, 7 (1962) s. 99-124. 
Wykaz druków należących do poszczególnych zakonów poprzedza Wprowadzenie. W jego treści starano się ująć encyklopedycznie te elementy historii, których znajomość jest przydatna przy rozpoznawaniu kalendarzy i schematyzmów. Dla zachowania przejrzystości treści rys historyczny prowincji przedstawiono jedynie w takim zakresie, by ułatwiona była identyfikacja poszczególnych roczników. Zawiera on: pełną nazwę zakonu lub zgromadzenia (w języku polskim i łacińskim), nazwisko założyciela, rok powstania lub zatwierdzenia zakonu (zgromadzenia) przez Stolicę Apostolską, następnie krótką genezę sprowadzenia zakonu na ziemie polskie i kształtowanie się struktur administracyjnych. To ostatnie zagadnienie nabiera szczególnego znaczenia w okresie porozbiorowym, gdy przynależność prowincjalna poszczególnych domów zakonnych zmieniała się co kilka lat. $Z$ tego też powodu uwzględniono również aktualnie obowiązujący podział administracyjny zakonów w Polsce.

Druki zestawiono chronologicznie według roku, na który został wydany, a podstawą opisu bibliograficznego był egzemplarz potraktowany jako całość. Przy każdej pozycji dokonano podziału druku na części wydawnicze: [cz. 1] - kalendarz, [cz. 2] - schematyzm. Zastosowano go każdorazowo, nawet gdy występuje tylko jedna część, gdyż celem jest nie tylko rozgraniczenie treści, wskazanie z ilu i jakich elementów składa się dana pozycja, ale również ułatwienie identyfikacji druku. Wielość użytych terminów w stosunku do tego samego rodzaju druku, powoduje bowiem, iż niekiedy trudno jest określić, do której kategorii on należy. Przy każdej z części wydawniczej w miarę zwięźle przedstawiono zawartość treści kalendarza i/lub schematyzmu. W części dotyczącej rubryceli oprócz jej zasadniczego zrębu pojawiają się informacje formalne tj. dekrety i zarządzenia władz kościelnych czy zakonnych, tabele faz księżyca, święta kościelne i państwowe oraz zalecane modlitwy. Niektóre $\mathrm{z}$ tych elementów umieszczano po schematyźmie, jednak pamiętać należy, iż ściśle związane były z kalendarzem liturgicznym. Osobną uwagę poświęcono wykazom zmarłych (nekrologom), które przede wszystkim na początku XIX wieku drukowano na końcu kalendarza. Ze względu na występowanie ich bezpośrednio po nim i wielokrotnie bez schematyzmu, wyodrębniono nekrologi z kalendarza i oznaczono w tekście jako [cz. 1a]. Nazwę tej części wydawniczej zaczerpnięto każdorazowo z nagłówka występującego w druku (m.in. Pia memoria, Defuncti, Defunctorum itp. ${ }^{19}$. Tym samym zrezygnowano z rozwiązania przyjętego przez Librowskiego, który uznawał nekrolog za zaczątek schematyzmu i określał go tak w tytule.

Część druga obejmująca schematyzm zawiera najczęściej informacje dotyczące następujących elementów: władze zakonu lub prowincji, historia zakonu, domów zakonnych, wykazy zakonników, indeksy itp. Wymieniany w tej części jest także wykaz zmarłych, jeżeli stanowi element katalogu.

W przeciwieństwie do Katalogu rubrycel i schematyzmów, nie zastosowano także podziału na fazy rozwojowe druków ${ }^{20}$. Przyjęte bowiem przez autora kryterium wspólnego lub osobnego występowania obu druków w jednym woluminie, w przypadku wydawnictw zakonnych wydaje się niewystarczającym ${ }^{21}$.

${ }^{19}$ Por. Krahel, Schematyzmy, s. 127.

${ }^{20}$ Por. Librowski, Katalog rubrycel i schematyzmów, s. 227.

${ }^{21}$ Przykładem mogą być kalendarze i schematyzmy paulińskie, które w zbiorze BU KUL występują łącznie, jednak analizując druki z tych samych lat, przechowywane w Bibliotece OO. Pauli- 


\section{Elementy opisu bibliograficznego}

\section{a) tytul druku}

Zgodnie z przyjętą praktyką, rubrycele i schematyzmy podawane są chronologicznie według roku, na który został wydany według tytułów a nie autorów ${ }^{22}$. Podstawą opisu wydawnictwa jest strona tytułowa pierwszego druku danego wydawnictwa występującego w zbiorze, a w przypadku zmiany tytułu - pierwszy druk, w którym zmiana nastąpiła ${ }^{23}$.

W przeciwieństwie do zaleceń Instrukcji, zdecydowano się przedstawić w opisie bibliograficznym pełny tytuł, nawet jeśli jest szczególnie obszerny i uroczysty lub obejmuje rozbudowaną tytulaturę (jest to widoczne zwłaszcza w schematyzmach zakonu augustianów i paulinów). Motywem tego była przede wszystkim chęć ukazania różnic i wielości elementów zawieranych w tytułach. W przypadku wystąpienia zmian w tytułach kolejnych roczników, przyjęto dwa rozwiązania. Jeżeli sytuacja dotyczy jednego rocznika bądź błędu w pisowni wyrazu lub ich ciągu, oznaczono ją w Uwagach podając zapis z rocznika wcześniejszego oraz występujący w danym roczniku ${ }^{24}$. Odmiennie potraktowano tytuły, których treść uległa istotnej zmianie. Wówczas podany jest tytuł w pełnym brzmieniu choć często wiąże się to z potrzebą powtórzenia jego obszernej treści zwłaszcza odnośnie roczników pochodzących z I połowy XIX w. W Uwagach podano każdorazowo numer pozycji w odniesieniu, do której zmiana nastąpiła.

W przypadku, gdy rubrycela połączona jest ze schematyzmem, w opisie notowane są obydwa tytuły. Tutaj szczególne zastosowanie ma omówiony powyżej podział druku na części wydawnicze: [cz. 1] - kalendarz, [cz. 1a] - wykaz zmarłych, [cz. 2] - schematyzm, co uwidocznione jest przed tytułem odpowiednim oznaczeniem. Zdarzają się również sytuacje, gdy brak jest na przykład strony tytułowej. Wówczas tytuł uzupełniany jest z okładki, a w przypadku jej braku scharakteryzowana nazwa druku podana zostaje w nawiasie kwadratowym [ ].

\section{b) autor druku}

Wyszczególnianie w omawianych drukach osób je tworzących jest praktyką dość późną i w XIX wieku podawanie nazwiska autora w tytule druku (główne rubryceli) jest sporadyczne. Jeżeli już występuje, to raczej pod koniec kalendarza liturgicznego, bardzo często jedynie w formie inicjałów (druki paulinów, augustianów). Dlatego w tym przypadku przyjęto dwa rozwiązania. Pierwsze dotyczy podania imienia i nazwiska autora zaraz po pełnym tytule druku co ma miejsce jedynie w przypadku, gdy jest on wyraźnie oznaczony na stronie tytułowej lub stronie kolejnej poprzez określenie umożliwiające utożsamienie go z autorem, redaktorem, osobą odpowiedzialna za opracowanie itp. (dotyczy ono przede wszystkim roczników wydanych po drugiej wojnie światowej). Drugie rozwiązanie zastosowano dla druków najczęściej sprzed 1945 r., gdy możliwe jest ustalenie

nów na „Skałce” w Krakowie, zauważyć można, iż funkcjonują one oddzielnie. Zagadnienie to wymaga jednak dalszych badań.

${ }^{22}$ Por. Librowski, Katalog rubrycel i schematyzmów, s. 228.

${ }^{23}$ Janowska, Opis bibliograficzny, s. 16.

${ }^{24}$ Tamże, s. 24. 
autora druku i wówczas jego imię i nazwisko (niekiedy jako rozwiązanie inicjałów) ujęte zostaje w Uwagach.

\section{c) miejsce i data wydania ${ }^{25}$}

W sytuacji, gdy brak jest oznaczenia miejsca wydania rocznika zastosowano skrót [b.m.]. Wyjątek stanowią druki paulińskie, w których identyfikacja miejsca wydaje się uzasadniona i tożsama z Częstochową, gdzie znajdowała się główna siedziba zakonu na ziemiach polskich oraz działająca tam drukarnia ${ }^{26}$.

Dla określenia roku wydania (rzadko występuje data dzienna) przyjęto z kolei odmienne rozwiązanie niż odnośnie miejsca wydania - gdy brak jest jego oznaczenia, starano się ustalić czas wydania druku podając rok wcześniejszy (antydatowanie). W sytuacji, gdy w treści podana jest dokładna data druku, odnotowano ją w Uwagach. Sytuacja tak ma miejsce przede wszystkim w katalogach jezuitów.

\section{d) wydawca, nakładca oraz drukarnia}

Brak wydawcy lub nakładcy oznaczono poprzez skrót [b.w.] a drukarni [b.d.]. Oznaczenie drukarni, zwłaszcza w drukach z XIX wieku było bardzo rzadko pomijane, dlatego też zdecydowano się dane te podać za każdym razem włącznie z uwzględnieniem adresu drukarni. Ze względu na specyfikę materiału źródłowego może być to przydatne szczególnie dla badaczy historii drukarstwa w Polsce.

\section{e) opis fizyczny}

Format druku podano wg długości grzbietu w centymetrach ${ }^{27}$.

Znacznie bardziej skomplikowana sytuacja ma miejsce przy określeniu objętości druku ze względu na stosowaną różnego rodzaju numerację stron. $Z$ tego też powodu zastosowano zasadę, iż w przypadku numerowanych stron podawana jest ich liczba (ss.), a gdy informacji tej brakuje - ustaloną liczbę stron w nawiasie kwadratowym [ ]. Oznaczono także egzemplarze interfoliowane z podaniem w nawiasie kwadratowym liczby dodatkowych kart (egz. interfol. $k k$. [...]).

W przypadku, gdy do czynienia mamy z kalendarzem i schematyzmem wydanym łącznie, przy pierwszej części występuje liczba stron całości druku, przy schematyźmie zaś strony, na których występuje tekst.

\section{f) strefa uwag}

Wszelkiego rodzaju adnotacje, z wyjątkiem Treści podano każdorazowo poniżej opisu bibliograficznego odnoszącego się do całości druku. Podzielono je na wewnętrzne części klasyfikując poszczególne elementy dla odpowiedniego ich wyróżnienia. Należą do nich:

${ }^{25}$ Odmiennie niż zaleca to Polska Norma, w strefie adresu wydawniczego po miejscu wydania podano rok wydania a nie jako powinno być - wydawcę. Dlatego też brak oznaczenia wydawcy przesunięto na dalszą pozycję łącząc ją z oznaczeniem nakładcy. Por. Janowska, Opis bibliograficzny, s. 34-37.

${ }^{26}$ Zob. szerzej np. H. Czerwień, Drukarnia paulinów w Częstochowie w latach 1730-1863, Bytom 1998; tenże, Założenie drukarni jasnogórskiej, „Studia Claromontana”, 8 (1987) s. 204221.

\footnotetext{
${ }^{27}$ Janowska, Opis bibliograficzny, s. 41.
} 
Treść: zawiera ogólne informacje o zawartości danego rocznika - osobno dla rubryceli i schematyzmu.

Proweniencja: podano ją w przypadku ustalenia osoby lub instytucji, do której druk należał zanim trafił do zasobu BU KUL.

Uwagi: dotyczą one przede wszystkim zmian w tytułach, odręcznych notatek, odniesień do innych pozycji bibliografii.

Oprawa: opis w tym przypadku zawiera podanie materiału, z jakiego wykonano okładzinę druku, cechy charakterystyczne, niekiedy także tytuł.

Sygnatura: podana każdorazowo.

Adnotowanie w innych bibliografiach: w niniejszym Katalogu odniesiono się do pierwszego wydania Bibliografii polskiej K. Estreichera (w tekście oznaczoną literą E.), Katalogu rubrycel i schematyzmów S. Librowskiego (w tekście oznaczoną literą L.), Bibliografii katolickich czasopism religijnych $w$ Polsce 1918-1944 pod redakcją Z. Zielińskiego oraz kontynuacji tej ostatniej opracowanej przez D. Wielgat ${ }^{28}$. Jest to element stały Katalogu ujmowany również w przypadku, gdy w żadnej z bibliografii nie jest druk notowany i wówczas brak danej pozycji w powyższych zestawieniach oznaczono pauzą (-). Rozwiązanie takie zostało przyjęte, bowiem wskazane wyżej bibliografie notują druki za różne okresy. Wyjątek zastosowano do bibliografii opracowanej przez D. Wielgat, która notowana jest jedynie wówczas, gdy występuje w niej dany druk. Tym samym możliwe staje się określenie, w jakim zakresie tworzony katalog zasobów BU KUL jest uzupełnieniem luki w tychże dziełach.

Elementy istotne dla opisu takie jak nazwa druku, rok, na który został wydany wyróżniono pogrubieniem w celu łatwiejszej identyfikacji. Nie robiono tego w stosunku do nazwy zakonu czy prowincji, gdyż informacje te podane są w nagłówku dotyczącym konkretnej prowincji.

\section{Skróty}

Wbrew Instrukcji wydawniczej ${ }^{29}$, bez ujednolicania do jednej wersji, pozostawiono skróty występujące $w$ tytule. Wydało się to tym bardziej słusznym, iż kolejne tytuły, jeśli nie zawierają zmian skracano do minimum a mianowicie podano jedynie pierwszy człon tytułu, określający rodzaj druku oraz rok, na który został wydany. Najczęściej używane w tekstach skróty przedstawiono w zestawieniu.

\section{Duże i małe litery}

Duże litery zastosowano zgodnie z regułą wydawniczą, zalecającą uwspółcześnianie zasad ortograficznych. Odstępstwo dotyczy skrótów tytulatury, przy których stosowaniu pozostawiono również pisownię dużą literą.

${ }^{28}$ K. Estreicher, Bibliografia polska, cz. 1, t. 1, Kraków 1870; t. 3, Kraków 1876; t. 4, Kraków 1878; t. 6, Kraków 1881; t. 7, Kraków 1882; cz. 2, t. 11, Kraków 1890; tenże, Bibliografia polska XIX stulecia. Lata 1881-1900, cz. IV, t. 1-4, Kraków 1906-1916; S. Librowski, Katalog rubrycel i schematyzmów, t. 27 (1973), cz. 2, s. 57-130; Bibliografia katolickich czasopism religijnych w Polsce 1918-1944, red. Z. Zieliński, Lublin 1981; Bibliografia katolickich czasopism religijnych w Polsce 1945-1989, oprac. D. Wielgat, Lublin 1996.

${ }^{29}$ Ihnatowicz, Projekt instrukcji wydawniczej, s. 108. 


\section{Nawiasy}

Uzupełnienia i wyjaśnienia ujęte $\mathrm{z}$ treści druku podano w nawiasach okrągłych ( ). Uzupełnienia z innych miejsc druku niż karta tytułowa lub oryginalna okładka oznaczono pomocą nawiasów kwadratowych [ ]. Dotyczy to przede wszystkim informacji uzupełniających obejmujących rok wydania, wydawcę, drukarnię i in. W nawiasach kwadratowych [ ] z użyciem wielokropka zaznaczono opuszczenia części tytułu w stosunku do wcześniejszego, najpełniejszego oraz rozwinięcia skrótów, zidentyfikowanych nazwisk, imion, tytułów oraz ewentualnych niejasności $-\mathrm{z}$ pytajnikiem lub określoną liczbą kropek odpowiadającą przypuszczalnej liczbie brakujących liter.

W cudzysłowie przytaczana jest treść adnotacji odręcznych, określenie proweniencji egzemplarza (u Librowskiego kursywą) oraz fragmenty oryginalnych tytułów lub fragmentów tekstu ujętych w Uwagach i cytowanych zgodnie z pisownią zastosowaną $\mathrm{w}$ druku.

Co do formy druku, podobnie jak w Katalogu zastosowano układ kolumnowy, nie tylko ze względu na ekonomiczność, ale przede wszystkim czytelności i łatwość w odszukaniu interesujących czytelnika pozycji.

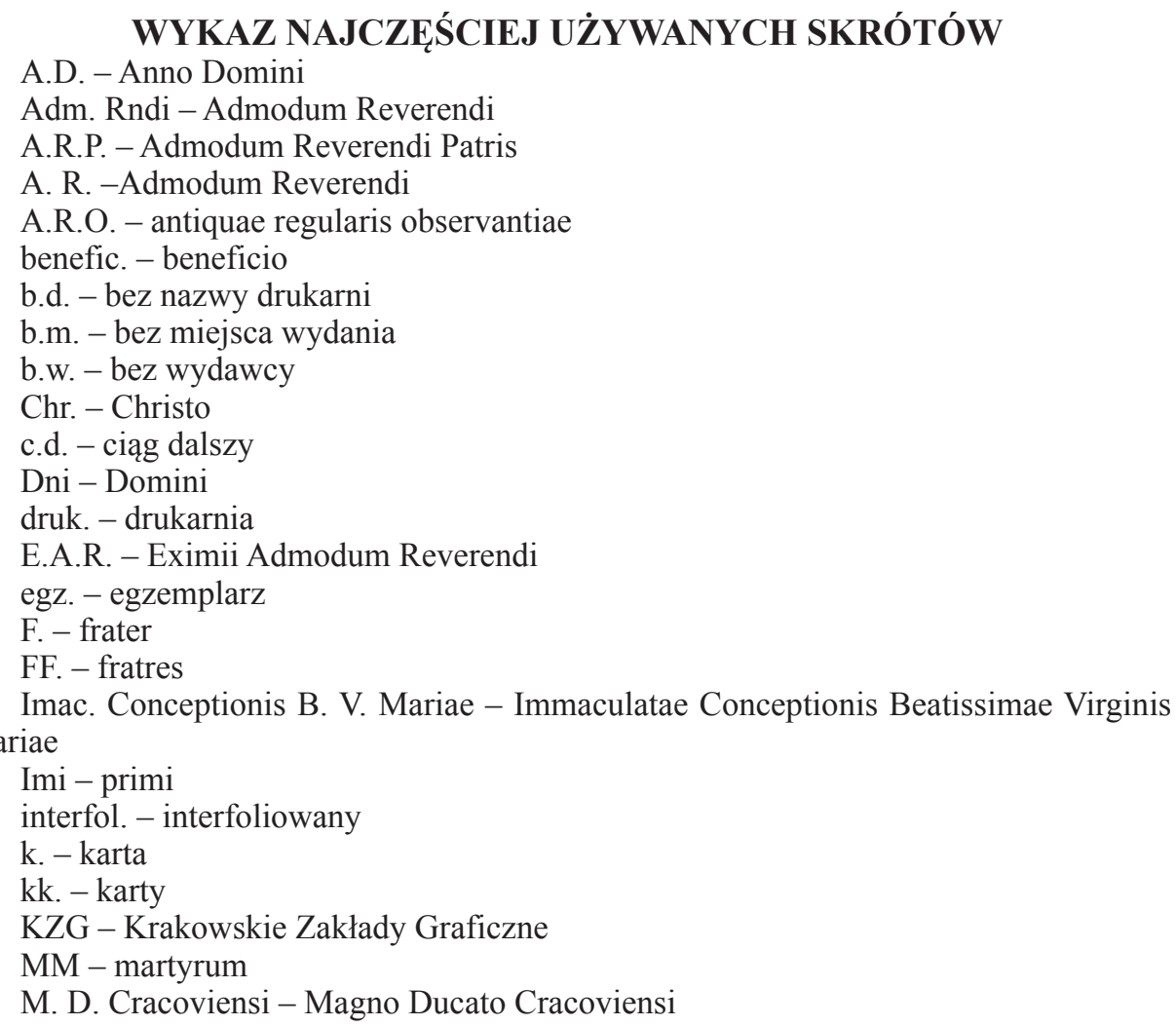


Mgri - magistri

Mag. - magistri

Min. - minorum

nlb. - nieliczbowane

NMP -Najświętsza Maryja Panna

nz. - niezapisane

o.o. - ojców

oprac. - opracowanie

Ord. - ordinis

O. Fr. M. - Ordo Fratrum Minorum

P. - pater

poz. - pozycja

PP. - patres

Pr. - primi

Pat. - Patavini

R.P. - Reverendi Patris

pw. - pod wezwaniem

red. - redakcja

Soc. Jesu - Societatis Jesu

S.P. - Sancti Patris

S.R.C. - Sacrae Rituum Congregationis

S.T.D. - Sacrae Theologiae Docotris

SS. - sorores

soro. - sorores

s. - strona

ss. - stron

św. - święty

typ. - typis

wyd. - wydawca

Xto - Christo 


\section{ZAKONY MECSKIE}

\section{AUGUSTIANIE-EREMICI}

Augustianie-eremici (Ordo Fratrum Eremitarum Sancti Augustini - OESA).

Zakon został założony w 1256 r. we Włoszech przez papieża Aleksandra IV, a jego celem była przede wszystkim praca duszpasterska i misyjna. Od 1303 r. stał się zakonem żebrzącym.

$\mathrm{Na}$ ziemie polskie eremici przybyli w XIII w. z Niemiec. Prowincję polską (I.1) utworzono w 1547 r., z której po III rozbiorze wydzielono kolejno prowincje rosyjską w 1795 r. (klasztory z niej skasowano do 1864 r.), pruską, a w 1797 r. galicyjską (I.2). Z klasztorów prowincji pruskiej i galicyjskiej, które znalazły się po 1809 r. w granicach Księstwa Warszawskiego, ponownie utworzono $\mathrm{w}$ roku 1811 prowincję polską (I.3).

Po kasatach popowstaniowych z całej prowincji przetrwał jedynie klasztor w Krakowie (I.4. Zakon po 1864 r.). Dopiero w 1909 r. augustianie założyli drugą placówkę w Prokocimiu. Stan ten trwał do 1950 r., kiedy to z upoważnienia Stolicy Apostolskiej zakon został w Polsce rozwiązany. Podejmowne od lat 70. XX w. próby odnowienia działalności zaowocowały powstaniem prowincji augustiańskiej w 1992 r.

\section{I.1. PROWINCJA POLSKA PRZED ROZBIORAMI (do 1795 r.)}

1. [cz. 1] Directorium divini officii juxta rubr. Brev. \& Missal. Romano Augustianiani ac Decr. Sac. Rit. Congr. ad usum Provinciae Polonae Fratrum Ordinis Eremitarum S.P. Augustini jussu Eximii Admodum Reverendi patris magistri Simonis Gorski sacrae theologiae doctoris ac ejusdem Provinciae Polonae de secundo prioris provincialis vigilantissimi editum pro Anno Domini 1777, Cracoviae [1776], [b.w.], Typis Collegii Majoris Universitatis Cracoviensis, $16 \mathrm{~cm}$., [40] ss.

Treść: zasadniczy zrąb kalendarza.
Oprawa: papier, miękka.

Uwagi: notatki na okładce i str. tyt. (nieczytelne).

Sygn.: KUL XVIII 7261/1777.

E. -, L. - , Z. -

2. [cz. 1] Directorium divini officii juxta rubricas Breviarii \& Missalis Romano-Augustianiani ac Decreta S.R. Congregationis ad usum Provinciae Polonae Fratrum Ordinis Eremitarum Sancti Patris Augustini jussu Eximii Admodum Reverendi patris magistri Simonis Woynicz sacrae theologiae doctoris, praedicatoris generalis Provinciae Polonae ejusdem Ordinis prioris provincialis vigilantissimi editum pro anno MDCCLXXXIX [1789], Lublini [1788], [b.w.], Typis S.R.M. PP. Trinitariorum, $16 \mathrm{~cm} .$, [52] ss.

Treść: jak w poz. 1.

[cz. 1a] Post impressionem praecedentis directorii defuncti in Provincia PP. \& FF, s. [52].

Uwagi: zmiana tytułu kalendarza.

Oprawa: brak

Sygn.: KUL XVIII 7261/1789.

E. - , L. - , Z. -

3. [cz. 1] Directorium [...] editum pro anno MDCCLCX [!] [1790], Lublini [1789], [b.w.], Typis S. R. M. PP. Trinitariorum, $16 \mathrm{~cm}$., [48] ss.

Treść: zasadniczy zrąb kalendarza.

[cz. 1a] Post impressionem praecedentis directorii defuncti in Provincia PP. \& FF, s. [48].

Oprawa: brak.

Sygn.: KUL XVIII 7261/1790.

E. - L. -

\section{I.2. PROWINCJA GALICYJSKA (1797-1810)}

1. [cz. 1] Ordo divini officii recitandi sacrique peragendi juxta ritum S.R.E. \& rubricas Breviarii ac Missalis Romano-Augustiniani ad usum Provinciae Gallicianae 
Fratrum Ordinis Eremitarum Sancti Patris Augustini jussu Eximii Adm. Rndi patris magistri Constantini Mierzwinski Provinaciae Gallicianae ejusdem Ordinis prioris provincialis vigillantissimi editus pro anno 1801, Cracoviae [1800], [b.w.], Typis Mathiae Dziedzicki, 17 cm., [54] ss.

Treść: kalendarium, zasadniczy zrąb kalendarza, Notanda scitu necessaria, Litaniae lauretanae.

[cz. 1a] Elenchus PP., FF. \& SS. in Provincia nostra defuctorum, s. [52].

Uwagi: brak stron.

Oprawa: brak.

Sygn.: KUL V-10533A/1801.

E. -, L. -

2. [cz. 1] Ordo [...] pro anno 1802, Cracoviae [1801], [b.w.], Typis Mathiae Dziedzicki, 17 cm., [46] ss., egz. interfol., [9] kk.

Treść: jak w poz. 1, bez Litaniae lauretanae.

[cz. 1a] Elenchus PP., FF. \& SS. [...] defuctorum, s. [44].

Oprawa: brak.

Uwagi: niektóre strony interfoliowane zapisane.

Sygn.: KUL V-10533A/1802.

E. cz.1, t. III, s. 807, L. -

3. [cz. 1] Ordo [...] pro anno 1804, Cracoviae [1803], [b.w.], Typis Mathiae Dziedzicki, $17 \mathrm{~cm}$., [48] ss.

Treść: zasadniczy zrąb kalendarza, Modus lucrandi indulgentias, Tabula ortus \& occasus solis $[\ldots]$.

[cz. 1a] Elenchus PP., FF. \& SS. ad benefic.ord. susceptor[...] defuctorum, s. [4647].

Uwagi: tytuł kalendarza, jak w poz. 1 ze zmianą: ,[...] ejusdem Ordinis rectoris provincialis [...]"; pieczątka z napisem: „K. 12 Kalend”; pieczatka z napisem: „G 6.. 12 Gr. ...”

Oprawa: brak.

Sygn.: KUL V-10533A/1804.

E. -, L. -

4. [cz. 1] Ordo divini officii recitandi sacrique peragendi juxta ritum S.R.E. \& rubricas Breviarii ac Missalis Romano-Augustiniani ad usum Provinciae Gallicianae Fratrum Ordinis Eremitarum Sancti Patris Augustini jussu Eximii Adm. Rndi patris magistri Aloysii Kupinski S.T.D. Provinaciae Gallicianae ejusdem Ordinis provincialis vigillantissimi in Annum Dni primum post bissextilem MDCCIX [1809] a fr. Eustachio Dziubinski ejusdem Ordinis alumno descriptus \& editus, Cracoviae [1808], [b.w.], Typis Annae Dziedzicka, 17 cm., [48] ss.

Treść: zasadniczy zrąb kalendarza, Notanda scitu necessaria.

[cz. 1a] Elenchus PP., FF., soro. et ad benefic. ord. susceptorum [...] defuctorum, s. [47].

Uwagi: zmiana tytułu kalendarza w stosunku do poz. 1

Oprawa: brak.

Sygn.: KUL V-10533A/1809.

E. cz.1, t. III, s. 807, L. -

\section{I.3. PROWINCJA POLSKA (1811-1864)}

1. [cz. 1] Ordo divini officii recitandi sacrique peragendi juxta ritum S.R.E. \& rubricas Breviarii ac Missalis Romano-Augustiniani ad usum Provinciae Polonae Duc. Vars. FF. Ordinis Eremitarum Sancti Patris Augustini jussu Eximii. Adm. Rndi patris magistri Constantini Mierzwiński S. T.D. provinciae \& Ordinis ejusdem de 2 do provincialis vigillantissimi in annum dni post bissextilem prim. MDCCCCXIII [!] [1813] a fr. Eustachio Dziubiński ejusdem Ordinis alumno descriptus \& editus, Cracoviae [1812], [b.w.], Typis M. Dziedzicki, $18 \mathrm{~cm}$., [50] ss.

Treść: kalendarium, zasadniczy zrąb kalendarza, na końcu, Tabula ortus \& ocassus [...]

[cz. 1a] Elenchus PP., FF., soror. et ad beneficia Ordinis [...] susceptorum [... defuctorum, s. [49].

Uwagi: zmiana tytułu kalendarza.

Oprawa: brak.

Sygn.: KUL V-10533A/1813. 
E. -, L. -

2. [cz. 1] Ordo [...] editum pro anno MDCCCXV [1815], Cracoviae [1814], [b.w.], Typis M. Dziedzicki, 18 cm., [48] ss.

Treść: jak w poz. 1, Phases lunae.

[cz. 1a] Elenchus patrum et fratrum [...] defuctorum, s. [44-45].

Oprawa: brak.

Sygn.: KUL V-10533A/1815.

E. - L. -

3. [cz. 1] Directorium divini officii ad normam consuetam Breviarii Romani pro Provincia Polona Ordinis Fratrum Eremitarum S.P. Augustini ordinatum sub regimine A.R.P. Alipii Niedzielski S.Th. mgri provincialis in anno 1819 impressum, [b. m. 1818], [b.w.d.], 16 cm., [32] ss.

Treść: zasadniczy zrąb kalendarza, Adnotationes.

Uwagi: zmiana tytułu kalendarza.

Oprawa: papier, miękka.

Sygn.: KUL V 10324/1819; KUL V-10533A/1819.

E. - L. -

4. [cz. 1] Directorium divini officii iuxta rubricas Breviarii et Missalis Romano Augustiniani ac Decreta Sacrae Rituum Congregationis ordinatum et ad usum Fratrum Eremitarum S.P.N. Augustini Provinciae Polonae ex mandato Eximii A.R. patris magistri Alipii Niedzielski eiusdem rdinis de tertio prioris provincialis vigillantissimi pro Anno Domini 1825, Varsaviae [1824], [b.w.d.], 17 cm., 58 ss.

Treść: zasadniczy zrąb kalendarza.

[cz. 1a] Elenchus patrum et fratrum Provinciae Polonae Ordinis Eremitarum S. P. Augustini, s. 55-58.

Treść: skład osobowy poszczególnych domów zakonnych (w tym żeńskiego), Index [...] defunctorum.

Uwagi: zmiana tytułu kalendarza.

Oprawa: papier, miękka.
Sygn.: KUL V 10324/1825.

E. - , L. -

5. [cz. 1] Directorium [...] pro Anno Domini 1828 editum, Varsaviae [1827], [b.w.d.], 17 cm., 24 ss.

Treść: jak w poz. 4.

[cz. 1a] Defuncti [...], s. 24.

Proweniencja: „Ex libris Pris Alexandri Tarłowski Augustiniani Filii Conventus Cracoviensis”.

Uwagi: zmiana tytułu: ,[...] Ordinis de quatro Prioris provincialis [...]", notatki atramentem.

Oprawa: papier, miękka.

Sygn.: KUL V 10324/1828.

E. -, L. -

6. [cz. 1] Directorium divini officii juxta rubricas Breviarii Romani Augustiniani ac Decreta S. Ritum Congregationis jussu Admodum Reverendi patris Krzanowski Provinciae Polonae ejusdem Ordinis rectoris vigilantissimi editum pro anno a partu Virginis 1832, [b.m. 1831], [b.w.d.], $16 \mathrm{~cm} .$, [46] ss.

Treść: jak w poz. 4.

Uwagi: zmiana tytułu kalendarza, str. tyt. napisana odręcznie, egzemplarz wykorzystywany był jako directorium na 1832 rok.

Oprawa: tektura.

Sygn.: KUL V-10533A/1810.

E. -, L. -

7. [cz. 1] Directorium divini officii ad normam consvetam Breviarii Romani pro Provincia Polona Ordinis Fratrum Eremitatarum S.P. Augustini ordinatum sub regimine A.R.P. Adeodati Buczkiewicz S.T. magistri provincialis de secondo in anno 1841 impressum, Varsaviae [1841], [b. w.d.], $17 \mathrm{~cm} ., 48 \mathrm{ss}$.

Treść: jak w poz. 4.

[cz. 2] Cathalogus religiosorum Ord. Eremitarum S.P. Augustini Provinciae Polonae, s. 42-48.

Treść: skład osobowy poszczególnych domów zakonnych (w tym żeńskiego), Defuncti.

Proweniencja: napis na okładce: „P. Clemens 
[Domagalski][?] 1841".

Uwagi: zmiana tytułu kalendarza i schematyzmu w stosunku do poz. 4, notatki odręczne.

Oprawa: papier, miękka.

Sygn.: KUL V 10324/1841.

E. - L. -

8.[cz. 1] Directorium divini officii juxta rubricas Breviarii et Missalis Romano Augustiniani ac Decreta Sacrae Rituum Congregationis ordinatum et ad usum Fratrum Aeremitarum [!] S.P.N. Augustini Provinciae Polonae ex mandato Eximii. A. R.P. magistri Adeodati Buczkiewicz priori provincialis de secundo pro Anno Domini MDCCCXLII [1842] editum, Varsaviae [842], [b.w.d.], 17 cm., 58 ss., egz. intefol. [11] kk.

Treść: jak w poz. 4.

[cz. 2] Cathalogus [...], s. 53-58.

Treść: jak w poz. 6.

Proweniencja: napis na okładce: „P. Clemens [Domagalski] [?] 1842”.

Uwagi: zmiana tytułu kalendarza w stosunku do poz. 6; notatki odręczne.

Oprawa: papier, miękka, brak tylnej oprawy.

Sygn.: KUL V 10324/1842.

E. -, L. -

9. [cz. 1] Ordo divini officii juxta rubricas S.R.E. nec non rubricas Missalis Romano-Augustiniani ac Decreta Sacrae Rituum Congregationis ad usum patrum Augustinianorum Provinciae Polonae jussu E. A.R. patris magistri Adeodati Buczkiewicz S.T.D. de 2 do provincialis vigilantissimi dispositus pro anno 1843, Varsaviae [1842], [b.w.d.], 16 cm., 56 ss., egz. interfol. [12] kk.

Treść: jak w poz. 4.

[cz. 2] Catalogus Ord. patrum ac fratrum S. Augustini Provinciae Polonae, s. 51-56.

Treść: skład osobowy poszczególnych domów zakonnych (w tym żeńskiego).

Uwagi: zmiana tytułu kalendarza stosunku do poz. 8 i schematyzmu w stosunku do poz. 6 .

Oprawa: miękka, papier.
Sygn.: KUL V 10324/1843.

E. -, L. -

10. [cz. 1] Directorium divini officii ad usum patrum Augustinianorum Provinciae Polonae pro anno bissextili 1844 jussu Eximii Adm. Rdi. p. mgri Adeodati Buczkiewicz S.T.D. de secundo provincialis dispositum, Varsaviae [1843], [b.w.d.], 16 cm., 42 ss., egz. interfol. [8] kk.

Treść: jak w poz. 4, Dedicationes et tituli Ecclesiarum.

[cz. 2] Cathalogus patrum et fratrum nec non monialium Ordinis S.P. Augustini Provinciae Polonae, s. 38-42.

Treść: jak w poz. 6 .

Uwagi: zmiana tytułu kalendarza i schematyzmu w stosunku do poz. 9 .

Oprawa: tektura, twarda.

Sygn.: KUL V 10324/1844.

E. - , L. -

11. [cz. 1] Directorium divini officii ad usum patrum ac fratrum Augustinianorum Provinciae Polonae pro anno 1845 jussu et auctoritate A.R.P. Theodori Załuski S.T.B. prioris provincialis editum, Varsaviae [1844], [b.w.], Tipis Scholarum Piarum, $16 \mathrm{~cm}$., 48 ss., egz. interfol. [7] kk.

Treść: jak w poz. 4 .

[cz. 2] Cathalogus [...], s. 43-48.

Treść: jak w poz. 6 .

Uwagi: zmiana tytułu kalendarza w stosunku do poz. 10.

Oprawa: tektura, twarda.

Sygn.: KUL V 10324/1845.

E. - L. -

12. [cz. 1] Ordo divini officii ad usum fratrum Ordinis S.P. Augustini Provinciae Polonae pro Anno Domini MDCCCXLVII [1847] post bissextilem 3io ex mandato A. R.P. Theodori Załuski S.T.B. ejusdem Provinciae prioris Provincialis editus ac propositus, Varsaviae [1846], [b.w.], Typis Scholarum Piarum, 16 cm., 40 ss., egz. intefol. [11] kk.

Treść: jak w poz. 4. 
Proweniencja: pieczęć z napisem: „Z biblioteki X. Zygmunta Wołek".

Uwagi: zmiana tytułu kalendarza w stosunku do poz. 11; najprawdopodobniej był schematyzm, notatki odręczne.

Oprawa: tektura, twarda.

Sygn.: KUL V-10324/1847.

E. -, L. -

13. [cz. 1] Ordo divini officii ad usum fratrum Augustinianorum Provinciae Polonae pro Anno Domini bissextili MDCCCXLVIII [1848] jussu et auctoritate A.R.P. Theodori Załuski S.T.B. ejusdem prioris provincialis dispositus, Varsaviae [1847], [b.w.], Typis Scholarum Piarum, $17 \mathrm{~cm}$., 44 ss., egz. interfol. [4] kk.

Treść: jak w poz. 4, Phases lunae.

[cz. 1a] Defuncti, s. 40.

Uwagi: zmiana tytułu kalendarza w stosunku do poz. 12.

Oprawa: papier, miękka, napis atramentem „1848”.

Sygn.: KUL V 10324/1848.

E. -, L. -

14. [cz. 1] Ordo divini officii ad usum patrum Augustinianorum Provinciae Polonae pro Anno Domini MDCCCXLIX [1849] jussu ac mandato A.R.P. Theodori Załuski S.T.B. ejusdem provinciae prioris provincialis dispositus, Varsaviae 1849, [b.w.], Typis Scholarum Piarum, 17 cm., 54, [2] ss.

Treść: jak w poz. 4.

Proweniencja: napis atramentem na str. tyt.: „Ad usum R.P. Clementis Domagalski Ords. S.P.N. Agustini concionatoris Cathedralis Cracoviae".

Uwagi: zmiana tytułu kalendarza w stosunku do poz. 13.

Oprawa: papier, półtwarda.

Sygn.: KUL V-10324/1849.

E. - L. -

15. [cz. 1] Directorium divini officii ad usum patrum ac fratrum Augustinianorum Provinciae Polonae pro Anno Domini MDCCCL [1850]. Jussu et auctoritate A.
R.P. provincialis editum, Varsaviae 1850, [b.w.], Typis Scholarum Piarum, $17 \mathrm{~cm}$., 48 ss., egz. intefol. [12] kk.

Treść: zasadniczy zrąb kalendarza, Phases lunae, Tabula ortus et occasus orbis.

[cz. 1a] Defuncti [...], s. 45.

Uwagi: zmiana tytułu kalendarza w stosunku do poz. 14; drugi egzemplarz w miękkiej oprawie, zawiera wklejkę z pocztem przełożonych prowincji Polskiej od 1790 r.

Proweniencja: pieczęć owalna $\mathrm{z}$ napisem: „, biblioteki X. Zygmunta Wołek".

Oprawa: tektura, twarda, złocone zdobienia oraz napis „1850”.

Sygn.: KUL V 10324/1850.

E. -, L. -

16. Sygn.: KUL V-10533/1851, KUL V-10533A/1851 - brak.

17. Sygn.: KUL V-10533/1852, KUL V-10533A/1852 - brak.

18. Sygn.: KUL V-10533/1853, KUL V-10533A/1853 - brak.

19. [cz. 1] Directorium divini officii ad usum patrum ac fratrum Augustinianorum Provinciae Polonae pro Anno Domini MDCCCLIV [1854], jussu et auctoritate A.R.P. Sigismundi Wołek S.T.B. prioris provincialis de secundo editum, [Częstochowa 1853], [b.w.], Typis Clari Montis Częstochoviensis, 15 cm., [72] ss. , egz. interfol. [23] kk.

Treść: jak w poz. 4, modlitwy.

Proweniencja: napis atramentem na stronie tytułowej: „Fr. Sigismundus Wołek”.

Uwagi: zmiana tytułu kalendarza w stosunku do poz. 15; notatki prywatne, gł. na kartach intefol. na str. tyt. rok 1854 przekreślony i zapisany „1865”, wklejka.

Oprawa: tektura, twarda.

Sygn.: KUL V-10533A/1854.

E. -, L. -

20. [cz. 1] Ordo divini officii et sacrificii ad usum patrum ac fratrum Augusti- 
nianorum Provinciae Polonae jussu et authoritate A.R.P. Sigismundi Wołek S.T.B. prioris provincialis de secundo pro Anno Domini MDCCCLV [1855] editum, [Częstochowa 1854], [b.w.], Typis Clari Montis Częstochoviensis, $16 \mathrm{~cm} .$, 74, [9] ss. + wklejka.

Treść: jak w poz. 4, modlitwy w jęz. pol.

[cz. 2] Schematismus patrum ac fratrum Ordinis Eremitarum S.P.N. Augustini Provinciae Polonae anno Christi 1855, [9] SS.

Treść: władze zwierzchnie zakonu, skład osobowy domów zakonnych (w tym żeńskiego).

Uwagi: zmiana tytułu kalendarza w stosunku do poz. 19 i schematyzmu w stosunku do poz. 10, notatki prywatne, wklejka - Tabella ortus [...]; Lunationes $[\ldots]-$ wklejka.

Oprawa: tektura, twarda.

Sygn.: KUL V-10533/1855 - tylko schematyzm,;

KUL V-10533A/1855;

KUL V-10324/1855, [błędna sygn. - KUL V10324/1854].

E. -, L. -

21. Sygn.: KUL V-10533/1856 - brak; KUL V-10533A/1856 - brak.

22. [cz. 1] Ordo divini officii recitandi sacrique peragendi juxta calendarium atque S.R.C. Decreta et rubricas Breviarii novissimas ad usum patrum ac fratrum Augustinianorum Provinciae Polonae jussu et authoritate A.R.P. Sigismundi Wołek S.T.B. prioris provincialis de secundo pro Anno Domini MDCCCLVII [1857] dispositus et editus, [Częstochowa 1856], [b.w.], Typis Claromontanis, $16 \mathrm{~cm}$., [72] ss. + wklejka.

Treść: biogram papieża, zasadniczy zrąb kalendarza, Adnotanda, Imperialis [...].

[cz. 2] Schematismus [...] pro anno 1857, s. [65-72].

Treść: jak w poz. 7.

Uwagi: zmiana tytułu kalendarza w stosunku do poz. 20; wklejka.

Oprawa: twarda, papier.

\author{
Sygn.: KUL V-10533/1857; \\ KUL V-10533A/1857. \\ E. - , L. -
}

23. [cz. 1] Ordo divini officii recitandi sacrique peragendi juxta calendarium atque S.R.C. Decreta et rubricas Breviarii novissimas ad usum patrum ac fratrum Ordinis Eremitarum S.P. Augustini Provinciae Polonae pro Anno Domini $\mathbf{1 8 5 8}$ dispositus ac editus, Varsaviae [1857], [b.w.], Ad Sanctam Crucem, $16 \mathrm{~cm}$., 40, [8] ss.

Treść: zasadniczy zrąb kalendarza, Adnotanda, modlitwy w jęz. polskim, Phases lunae, Imperialis [...].

[cz. 2] Schematismus patrum ac fratrum Ord. SPN. Augustini, s. 37-40.

Treść: jak w poz. 6 .

Uwagi: zmiana tytułu kalendarza w stosunku do poz. 22 i schematyzmu w stosunku do poz. 20.

Oprawa: tektura, twarda.

Sygn.: KUL V-10324/1858.

E. - L. -

24. [cz. 1] Ordo divini officii recitandi sacrique peragendi juxta calendarium atque S.R.C. Decreta et rubricas Breviarii novissimas ad usum patrum ac fratrum Ordinis Eremitarum S.P. Augustini Provinciae Polonae pro Anno Domini 1861 dispositus ac editus jussu A.R.P. Rajmundi Krajewski S. T.B. prioris provincialis, Varsaviae [1860], [b.w.], ad Sanctam Crucem, 18 cm., 42, [8] ss.

Treść: jak w poz. 4, Adnotanda, Litaniae Lauretanae, Imperialis ac regalis palatii dies festivi, In omnibus festis palati [...].

[cz. 2] Schematismus patrum ac fratrum monialiumque Ord. S.P. Augustini Provinciae Polonae, s. 37-42.

Treść: jak w poz 6.

Proweniencja: inicjały na okładce: „X. B[onawentura] S[więtczak]" [?].

Uwagi: zmiana tytułu kalendarza i schematyzmu w stosunku do poz. 23.

Oprawa: tektura, twarda.

Sygn.: KUL V-10324/1861.

E. cz.1, t. III, s. 807, L.- 
25. [cz. 1] Ordo [...] pro Anno Domini 1863 [...] prioris provincialis de secundo, Varsaviae [1862], [b.w.], ad Sanctam Crucem, $18 \mathrm{~cm} ., 50,[8] \mathrm{ss}$.

Treść: jak w poz. 4, Hymnum w jęz. łac., Statutum Capituli Varsaviensis [...], Imperialis ac regalis palatii dies festivi, In solemnioribus festis palatii [...], Qvaedam Decreta [...]. s. $40-44$.

[cz. 1a] Series priorum (1761-1860),

[cz. 2] Schematismus [...], s. 45-50.

Treść: jak w poz. 7.

Uwagi: zmiana tytułu kalendarza w stosunku do poz. 24; notatki odręczne.

Oprawa: tektura, twarda, złocenia, napis „1863”.

Sygn.: KUL V-10324/1863.

Sygn.: KUL V-10533/1863 (schematyzm) brak.

E. cz.1, t. III, s. 807 , L. -

26. [cz. 1] Ordo divini officii recitandi sacrique peragendi ad usum patrum ac fratrum Ordinis Eremitarum S.P. Augustini Provincia Polona pro Anno Domini 1864, Varsaviae 1864, [b.w.d.], 23 cm., 63 ss.

Treść: jak w poz. 4, Imperialis [...], In omnibus festis palati [...], Hymnum.

[cz. 1a] Defuncti [...], s. 57.

Uwagi: zmiana tytułu kalendarza w stosunku do poz. 24, rękopis.

Oprawa: papier, miękka.

Sygn.: KUL V-10324/1864.

E. cz.1, t. III, s. 807, L. -

\section{I.4. ZAKON PO 1864 r.}

1. [cz. 1] Ordo divini officii recitandi sacrique peragendi ad usum patrum ac fratrum Ordinis Eremitarum S.P. Augustini Conventus Cracoviensis jessu Eximii Adm. Rndi patris Sigismundi Wołek S.T.D. Provinciae Polonae ejusdem Ordinis bis exprovincialis, commissarii generalis editus pro Anno Domini 1866, Cracoviae 1866, Typis J. Bensdorff, 20 cm., 40 ss.

Treść: zasadniczy zrąb kalendarza. [cz. 1a] Series eximiorum patrum [...] Provinciae Polonae, Series conventuum Provinciae [...] Polonae, Moniales Ordinis [...] decretum, s. 29-36.

[cz. 2] Schematismus patrum, fratrum et monialium Ordinis Eremitarum S.P. Augustini in Magno Ducatu Cracoviensi pro anno 1866 sub gloriosissimis auspiciis cardinalis protectoris Eminentissimi D. D. Constantini Patrizi nec non Reverendissimi prioris generalis p. mag. Joannis Belluomini Romani, s. 37-40.

Treść: skład osobowy poszczególnych domów zakonnych.

Proweniencja: na karcie tytułowej pieczęć owalna, napis: „Z biblioteki X. Zygmunta Wołek”.

Uwagi: na s. 28 napis: „Opera EARP. Sigismundi Wołek STD. bis Exprovincialis, Commissarii Generalis annus XVII".

Oprawa: papier wydaw., miękka, na okładce napis: „Ordo divini officii”, data „1866”-czerwona kredka.

Sygn.: KUL V-10533/1866, KUL V10533A/1866.

E. cz.1, t. III, s. 807 , L. s. 385 (tylko schematyzm).

2. [cz. 1] Ordo divini officii recitandi sacrique peragendi Anno Domini 1867 a patribus ac fratribus Ordinis Eremitarum S.P. Augustini Conventus Cracoviensis jessu Eximii Adm. Rndi patris Sigismundi Wołek S.T.D. Provinciae Polonae ejusdem Ordinis bis exprovincialis, commissarii generalis dispositus et editus, Cracoviae 1867, [b.w.], Typis Josephi Bensdorff, 19 cm., 40 ss., [4] kk.

Treść:jak w poz. 1, Copia Indulti Apostolici.

[cz. 2] Schematismus patrum, fratrum et monialium Ordinis Eremitarum S.P. Augustini in Magno Ducatu Cracoviensi pro anno 1867 sub gloriosissimis auspiciis protectoris totius Ordinis Eminentissimi ac Reverendissimi DD. Constantini Patrizi S. R. Ecclesiae cardinalis, episcopi Portuensis et S. Rufinae, Basilicae Liberianae archypresbiteri, SS. D.N. Papae vicarii generalis etc. etc. etc. nec non Reverendissimi prio- 
ris generalis p. mag. Joannis Belluomini Romani electi in capitulo generali Romae in conventu S.P. Augustini die 6 Junii 1865 an. celebrato, SS. Rituum Congregationis consultoris etc. etc., s. 31-40.

Treść: władze zwierzchnie, skład osobowy poszczególnych domów zakonnych (w tym żeńskiego), Defuncti, Series eximiorum patrum [...] Provinciae Polonae, Series conventuum Provinciae [...] Polonae, moniales Ordinis [...] decretum.

Proweniencja: na karcie tytułowej pieczątka owalna: „Z biblioteki X. Zygmunta Wołek”.

Uwagi: zmiana tytułu kalendarza i schematyzmu w stosunku do poz. 1; na s. 29 napis: „Opera EARP. Sigismundi Wołek STD. bis Exprovincialis, Commissarii Generalis annus XVIII".

Oprawa: tekturka, półtwarda, tytuł na okładce (wycięty z okładki oryginalnej): „Ordo divini officii, data atramentem 1867”; ołówkiem napis: „et schem. et series".

Sygn.: KUL V-10533/1867, KUL V10533A/1867.

E. cz.1, t. III, s. 807 , L. -

3. [cz. 1] Ordo divini officii recitandi sacrique peragendi Anno Domini bissexto 1868 a patribus ac fratribus Ordinis Eremitarum S.P. Augustini Conventus Cracoviensis jussu Eximii Adm. Rdi patris Sigismundi Wołek S.T.D. Provinciae Polonae ejusdem Ordinis bis exprovincialis, commissarii generalis dispositus et editus, Cracoviae 1868, [b.w.], Typis J. Bensdorff, 18 cm., 40, 10 ss.

Treść: jak w poz. 1, Documenta [...].

[cz. 2] Schematismus [...] pro anno 1868 [...], s. 33-40.

Treść: władze zwierzchnie, skład osobowy poszczególnych domów zakonnych (w tym żeńskiego), Defuncti, Nota [...], Series priorissarum.

Uwagi: zmiana tytułu kalendarza w stosunku do poz. 2; dołączony schematyzm na rok 1867 ; na s. 30 napis: „Opera EARP. Sigismundi Wołek STD. bis Exprovincialis, Commissarii Generalis annus XIX"

Oprawa: półtwarda, tekturka, nowa, tytuł na okł (wycięty z okładki oryginalnej): „Ordo divini officii pro anno $1868^{\prime}$.

Sygn.: KUL V-10533/1868, KUL V-
10533A/1868.

E. cz.1, t. III, s. 807 , L. -

4. [cz. 1] Ordo [...] Anno Domini 1869 [...], T. Piekarii 1869, [b.w.], Typis Theodori Heneczek, $18 \mathrm{~cm}$., 50 ss.

Treść: jak w poz. 1, Documenta [...], Adnotanda.

[cz. 2] Schematismus [...] pro anno 1869 [...], s. 37-50.

Treść: władze zwierzchnie, skład osobowy poszczególnych domów zakonnych (również żeńskiego), w tym w Królestwie Polskim, Necrologia monialium, Priores provinciales Provinciae Polonae, Series conventum Provinciae [...] Polonae [...].

Uwagi: na s. 34 napis: „Opera EARP. Sigismundi Wołek STD. bis Exprovincialis, Commissarii Generalis annus XX”.

Oprawa: papier wydaw., miękka, napis: „Ordo Divini Officii 1869".

Sygn.: KUL V-10533/1869, KUL V10533A/1869.

E. - L. -

5. [cz. 1] Ordo [...] Anno Domini 1870 [...], T. Piekarii 1870, [b.w.], Typis Theodori Heneczek, 18 cm., 54 ss., [1] k.

Treść: jak w poz. 1.

[cz. 2] Schematismus patrum, fratrum et monialium Ordinis Eremitarum S.P. Augustini in Magno Ducatu Cracoviensi pro anno 1870 sub gloriosissimis auspiciis Eminentissimi ac Reverendissimi DD. Constantini Patrizi S.R. Ecclesiae cardinalis, episcopi Portuensis et S. Rufinae, Basilicae Liberianae archypresbiteri, SS. D. Papae vicarii generalis etc. etc. etc. nec non Reverendissimi prioris generalis p. mag. Joannis Belluomini Romani electi in capitulo generali Romae in conventu S.P. Augustini die 6 Junii 1865 an. celebrato, SS. Rituum Congregationis consultoris etc. etc., s. 37-54.

Treść: władze zwierzchnie, skład osobowy poszczególnych domów zakonnych (również żeńskiego), bez Królestwa Polskiego, Defuncti, Series prio$\operatorname{rum}[\ldots]$.

Proweniencja: napis atramentem na okładce: „Sutor”. 
Uwagi: tytuł kalendarza ze zmianą - zamiast: [...] bis Exprovincialis, Commissarii Generalis [...] jest: [...] bis Exprovincialis, Commssarli [!] Generalis [...]; zmiana tytułu schematyzmu w stosunku do poz. 2; na s. 35 napis: „Opera EARP. Sigismundi Wołek STD. bis Exprovincialis, Commissarii Generalis annus XX".

Oprawa: papier, miękka, napis atramentem trudny do odczytania.

Sygn.: KUL V-10533/1870, KUL V10533A/1870.

E. -, L. s. 386 (tylko schematyzm).

6. [cz. 1] Ordo [...] Anno Domini 1871 [...], T. Piekarii 1871, [b.w.], Typis Theodori Heneczek, $18 \mathrm{~cm}$., 48 ss.

Treść: jak w poz. 1.

[cz. 2] Schematismus [...] pro anno $1871[\ldots]$, s. 37-48.

Treść: władze zwierzchnie, skład osobowy poszczególnych domów zakonnych (również żeńskiego) oraz w Królestwie Polskim, Defuncti.

Uwagi: na s. 35 napis: „Opera EARP. Sigismundi Wołek STD. bis Exprovincialis, Commissarii Generalis annus XXI".

Oprawa: papier, miękka, oryginalna, napis: „Ordo Divini Officii 1871”.

Sygn.: KUL V-10533/1871, KUL V10533A/1871.

E. - , L. -

7. [cz. 1] Ordo [...] anno 1872 [...], T. Piekarii 1872, [b.w.], Typis Theodori Heneczek, $18 \mathrm{~cm}$., $50 \mathrm{ss}$.

Treść: jak w poz. 1, Additamentum.

[cz. 2] Schematismus patrum, fratrum et monialium Ordinis Eremitarum S.P. Augustini in Magno Ducatu Cracoviensi pro anno 1872 sub gloriosissimis auspiciis Eminentissimi ac Reverendissimi DD. Constantini Patrizi S. Romanae Ecclesiae cardinalis, episcopi Ostiensis et Veliternensis, decani Sacri Collegii, SS. D.N. Papae vicarii generalis etc. etc. etc. nec non Reverendissimi prioris generalis p. mag. Joannis Belluomini Romani electi in capitulo generali Romae in conventu S.P. Augustini die 6 Junii 1865 an. celebrato, SS. Rituum
Congregationis consultoris etc. etc., s. 4350.

Treść: jak w poz. 6, bez Królestwa Polskiego.

Oprawa: miękka, papier, napis: „Schematismus 1872 ".

Uwagi: zmiana tytułu schematyzmu w stosunku do poz. 5; dwie wersje: schematyzm łącznie z kalendarzem oraz schematyzm, jako wydawnictwo samoistne.

Sygn.: KUL V-10533/1872 - schematyzm. KUL V-10533A/1872 - ordo divini oraz schematyzm.

E. -, L. s. 386 (tylko schematyzm).

8. [cz. 1] Ordo [...] Anno Domini 1873 [...], T. Piekarii 1873, [b.w.], Typis Theodori Heneczek, $18 \mathrm{~cm} ., 52$ ss.

Treść:jak w poz. 1.

[cz. 2] [Schematyzm Ordinis Eremitarum S.P. Augustini in Magno Ducatu Cracoviensi], s. 43-52.

Treść: władze zwierzchnie, historia domu zakonnego, skład osobowy poszczególnych domów zakonnych (również żeńskiego) oraz w Królestwie Polskim, Defuncti.

Uwagi: brak tytułu schematyzmu.

Oprawa: papier wydaw., miękka, napis: „Ordo divini officii 1873".

Sygn.: KUL V-10533/1873, KUL V10533A/1873.

E. - , L. -

9. [cz. 1] Ordo [...] Anno Domini 1874. [...], Cracoviae 1874, Typis Universitatis Jagellonicae, provisore Ignatio Stelcel, $18 \mathrm{~cm}$., 46 ss., [1] k.

Treść: jak w poz. 1 .

[cz. 2] Schematismus [...] pro anno 1874 [...], s. 39-46.

Treść: jak w poz. 8 .

Uwagi: na s. 28 napis: „Opera EARP. Sigismundi Wołek STD. bis Exprovincialis, Commissarii Generalis annus XXV".

Oprawa: papier wydaw., miękka, napis: jak na str. tyt.

Sygn.: KUL V-10533/1874, KUL V10533A/1874. 


$$
\text { E. - , L. - }
$$

10. [cz. 1] Ordo [...] Anno Domini 1875 [...], Cracoviae 1875, Typis Universitatis Jagellonicae, provisore Ignatio Stelcel, $17 \mathrm{~cm} ., 34,7 \mathrm{ss}$.

Treść: jak w poz. 1.

[cz. 2] Schematismus [...] pro anno 1875 [...], 7 ss.

Treść: jak w poz. 7.

Uwagi: na s. 34 napis: „Opera EARP. Sigismundi Wołek STD. bis Exprovincialis, Commissarii Generalis annus XXVI".

Oprawa: papier wydaw., miękka, napis: jak na stronie tytułowej

Sygn.: KUL V-10533/1875, KUL V10533A/1875.

E. -, L. -

11. [cz. 1] Ordo [...] Anno Domini 1876 [...], Cracoviae 1876, Typis Universitatis Jagellonicae, provisore Ignatio Stelcel, $19 \mathrm{~cm} ., 48$, VIII ss.

Treść: jak w poz. 1, Hymnus, Litaniae Beatae Mariae Virginis.

[cz. 2] Schematismus [...] pro anno 1876 [...], s. 42-48.

Treść: jak w poz. 7 .

Proweniencja: na karcie tytułowej pieczątka owalna: „Z biblioteki x. Zygmunta Wołek”,

Oprawa: tektura, twarda, naklejona okładka; napis - jak na karcie tytułowej, bez roku wydania.

Sygn.: KUL V-10533/1876, KUL V10533A/1876.

E. -, L. -

12. [cz. 1] Ordo [...] Anno Domini 1877 [...], Cracoviae 1877, Typis Universitatis Jagellonicae, provisore Ignatio Stelcel, $19 \mathrm{~cm} ., 36$, , [8] ss., schematyzm z roku $1866-2$ karty.

Treść: jak w poz. 1, Series eximinorum patrum [...], Series conventuum [...], Moniales Ordinis [...].

[cz. 2] Schematismus [...] pro anno 1877 [...], [8] ss.

Treść: jak w poz. 7.

Uwagi: na s. 28 naklejona kartka $\mathrm{z}$ napisem:
„Opera EARP. Sigismundi Wołek STD. bis Exprovincialis, Commissarii Generalis annus XXVIII".

Oprawa: papier wydaw., miękka, napis: „Ordo divini officii".

Sygn.: KUL V-10533/1877, KUL V10533A/1877.

E. - , L. -

13. [cz. 1] Ordo [...] Anno Domini 1878 [...], Cracoviae 1878, Typis Universitatis Jagellonicae, provisore Ignatio Stelcel, 19 cm., 29, [8] ss., schematyzm z roku 1867 (s. 31-40).

Treść: jak w poz. 1, Copia Indulti Apostolici [...].

[cz. 2] Schematismus patrum, fratrum et monialium Ordinis Eremitarum S.P. Augustini in Magno Ducatu Cracoviensi pro anno 1878 sub gloriosissimis auspiciis Eminentissimi ac Reverendissimi D.D. Thomae Maria Martinelli S. Romanae Ecclesiae cardinalis presbyteri tit. S. Priscae etc. nec non Reverendissimi prioris generalis p. mag. Joannis Belluomini Romani electi in capitulo generali Romae in conventu S.P. Augustini die 6 Junii 1865 an. celebrato, reelecti vero 1877 an. SS. Rituum Congregationis consultoris etc. etc., [8] ss.

Treść: jak w poz. 7.

Uwagi: tytuł kalendarza, jak w poz. 1 ze zmianą - zamiast: [...] jussu Eximii Adm. Rdi patris, jest: [...] juessu Eximii Admod. Rndi patris [...]; zmiana tytułu schematyzmu w stosunku do poz. 7; na s. 29 naklejona kartka z napisem: „Opera EARP. Sigismundi Wołek STD. bis Exprovincialis, Commissarii Generalis annus XXIX".

Oprawa: papier wydaw., miękka, napis: „Ordo divini officii”; ołówkiem: „1878”.

Sygn.: KUL V-10533/1878, KUL V10533A/1878.

E. -, L. -

14. [cz. 1] Ordo [...] Anno Domini 1879 [...], Cracoviae 1879, Typis Universitatis Jagellonicae, provisore Ignatio Stelcel, 18 cm., 38, [8] ss., schemtayzm z roku 1873 (s. 39-52). 
Treść: jak w poz. 1.

[cz. 2.] Schematismus patrum, fratrum et monialium Ordinis Eremitarum S. P. Augustini in Magno Ducatu Cracoviensi pro anno 1879 sub gloriosissimis auspiciis Eminentissimi ac Reverendissimi D.D. Thomae Maria Martinelli S. Romanae Ecclesiae cardinalis presbyteri tit. S. Priscae praefecti Sacrae Congregationis Indicis etc. nec non Reverendissimi prioris generalis p. mag. Joannis Belluomini Romani electi in capitulo generali Romae in conventu S.P. Augustini die 6 Junii 1865 an. celebrato, reelecti vero 1877 an. SS. Rituum Congregationis consultoris etc. etc., [8] ss.

Treść: jak w poz. 8.

Uwagi: tytuł kalendarza, jak w poz. 2 ze zmianą - zamiast: [...] jussu Eximii Adm. rdi patris [...], jest: [...] jussu Eximii Admod. Rndi patris [...]; zmiana tytułu schematyzmu w stosunku do poz. 39 ; na s. 38 naklejona kartka z napisem: „Opera EARP. Sigismundi Wołek STD. bis Exprovincialis, Commissarii Generalis annus XXX".

Oprawa: papier wydaw., miękka, napis: „Ordo divini officii 1879".

Sygn.: KUL V-10533A/1879 -kalendarz i schematyzm.

KUL V-10533/1879 - schematyzm.

$$
\text { E. - , L. - }
$$

15. [cz. 2] Schematismus patrum, fratrum et monialium Ordinis Eremitarum S. P. Augustini in Magno Ducatu Cracoviensi pro anno $\mathbf{1 8 8 1}$ sub gloriosissimis auspiciis Eminentissimi ac Reverendissimi D.D. Thomae Maria Martinelli S. Romanae Ecclesiae cardinalis presbyteri tit. S. Priscae S. Congr. Indicis praefecti etc. nec non Reverendissimi p. mag. Joannis Belluomini Romani electi in capitulo generali Romae in conventu S.P. Augustini die 6 Junii 1865 an. celebrato, reelecti vero 1877 an. SS. Rituum Congregationis consultoris etc. etc., Cracoviae 1881, Typis Universitatis Jagellonicae, provisore Ignatio Stelcel, $17 \mathrm{~cm}$., [10] ss.

Treść: jak w poz. 8.
Uwagi: zmiana tytułu schematyzmu w stosunku do poz. 14; egzemplarz ten dołaczony jest do rocznika z 1870 r.

Oprawa: brak.

Sygn.: KUL V-10533/1881.

E. -, L. -

16. [cz. 1] Ordo [...] Anno Domini 1882. [...], Cracoviae 1882, Typis Universitatis Jagiellonicae, provisore Ignatio Stelcel, 19 cm., 44 ss., schematyzm z roku 1875 (s. 36-48).

Treść: jak w poz. 1.

[cz. 2] Schematismus [...] pro anno 1882 [...], Cracoviae 1882, Typis Universitatis Jagiellonicae, provisore Ignatio Stelcel, s. 36-44.

Treść: jak w poz. 8 .

Uwagi: na s. 35 naklejona kartka z napisem: „Opera EARP. Sigismundi Wołek STD. bis Exprovincialis, Commissarii Generalis annus XXXIII".

Oprawa: papier, miękka, napis: „Ordo divini officii 1882".

Sygn.: KUL V-10533/1882, KUL V10533A/1882.

E. -, L. -

17. [cz. 2] Schematismus [...] pro anno 1883 [...], Cracoviae 1883, Typis Universitatis Jagiellonicae, provisore Ignatio Stelcel, $20 \mathrm{~cm} ., 8 \mathrm{ss}$.

Treść: jak w poz. 7.

Oprawa: brak.

Sygn.: KUL V-10533/1883.

E. -, L. -

18. [cz. 1] Ordo [...] Anno Domini 1884 [...], Cracoviae 1884, [b.w.], Typis Universitatis Jagellonicae, provisore Ignatio Stelcel, 17 cm., 38, 9 ss., schematyzm z roku 1873 (s. 39-52).

Treść: jak w poz. 1.

[cz. 2] Schematismus patrum, fratrum et monialium Ordinis Eremitarum S.P. Augustini in Magno Ducatu Cracoviensi pro anno $\mathbf{1 8 8 4}$ sub gloriosissimis auspiciis Eminentissimi ac Reverendissimi D.D. Thomae Maria Martinelli S. Romanae Ecc- 
lesiae cardinalis presbyteri tit. S. Priscae S. Congr. Indicis praefecti etc. nec non Reverendissimi p. magistri Pacifici Neno Romani totius S. Ordinis Eremitarum S.P. Augustini commisarii generalis etc. etce, Cracoviae 1884, Typis Universitatis Jagellonicae, provisore Ignatio Stelcel, 9 ss.

Treść: jak w poz. 7.

Uwagi: zmiana tytułu schematyzmu w stosunku do poz. 15; na s. 38 naklejona kartka z napisem: „Opera EARP. Sigismundi Wołek STD. bis Exprovincialis, Commissarii Generalis annus XXX” [powinno być annus XXXV].

Oprawa: papier wydaw., miękka, napis: „Ordo divini officii 1884".

Sygn.: KUL V-10533/1884, KUL V10533A/1884.

E. cz. 4, t. IV, s. 123 (tylko schematyzm), L. -

19. [cz. 1] Ordo [...] Anno Domini 1885, Cracoviae 1885, [b.w.], Typis Universitatis Jagellonicae, provisore Ignatio Stelcel, $18 \mathrm{~cm}$., $52 \mathrm{ss}$.

Treść: jak w poz. 1, Scitu necessaria.

[cz. 2] Schematismus patrum, fratrum et monialium Ordinis Eremitarum S.P. Augustini in Magno Ducatu Cracoviensi pro anno 1885 sub gloriosissimis auspiciis Eminentissimi ac Reverendissimi D.D. Thomae Maria Martinelli S. Romanae Ecclesiae tituli S. Sabinae episcopi cardinalis, S. Congr. Indicis praefecti etc. nec non Reverendissimi p. magistri Pacifici Neno Romani totius S. Ordinis Eremitarum S.P. Augustini commisarii generalis, Cracoviae 1885, [b.w.], Typis Universitatis Jagellonicae, provisore Ignatio Stelcel, c.d. s. 4352.

Treść: jak w poz. 7.

Uwagi: zmiana tytułu schematyzmu w stosunku do poz. 18; na s. 42 napis: „Opera EARP. Sigismundi Wołek STD. bis Exprovincialis, Commissarii Generalis annus XXXVI".

Oprawa: papier wydaw., miękka, napis: „Ordo divini officii 1885 ".

Sygn.: KUL V-10533/1885, KUL V10533A/1885.

E. - L. -
20. [cz. 1] Ordo [...] Anno Domini 1886 [...], Cracoviae 1886, [b.w.], Typis Universitatis Jagiellonicae, provisore Ignatio Stelcel, $18 \mathrm{~cm}$., $51 \mathrm{ss}$.

Treść: jak w poz. 1.

[cz. 2] Schematismus [...] pro anno 1886 [...], Cracoviae 1886, [b.w.], Typis Universitatis Jagiellonicae, provisore A. M. Kosterkiewicz, s. 43-51.

Treść: jak w poz. 7.

Uwagi: na s. 42 napis: „Opera EARP. Sigismundi Wołek STD. bis Exprovincialis, Commissarii Generalis annus XXXVII".

Oprawa: papier wydaw., miękka, napis: „Ordo divini officii 1886".

Sygn.: KUL V-10533/1886, KUL V10533A/1886.

E. - , L. -

21. [cz. 1] Ordo [...] Anno Domini 1887 [...], Cracoviae 1887, [b.w.], Typis Universitatis Jagellonicae, provisore A. M. Kosterkiewicz, 18 cm., 54 ss., [1] k.

Treść: jak w poz. 1, Notificatio.

[cz. 2] Schematismus [...] pro anno 1887 [...], Cracoviae 1887, [b.w.], Typis Universitatis Jagiellonicae, provisore A. M. Kosterkiewicz, s. 45-54.

Treść: jak w poz. 7.

Uwagi: tytuł kalendarza, jak w poz. 2 ze zmianą - zamiast: [...] jussu Eximii Adm. Rdi patris Sigismundi Wołek S.T.D. Provinciae Polonae [...], jest: [...] jussu Eximii Admond. Rndi patris Sigismundi Wołek S.T.D. Provinciae Polonie [...]; na s. 39 napis: „Opera EARP. Sigismundi Wołek STD. bis Exprovincialis, Commissarii Generalis annus XXXVIII".

Oprawa: papier wydaw., miękka, napis: „Ordo divini officii 1887”.

Sygn.: KUL V-10533/1887, KUL V10533A/1887.

E. - , L. -

22. [cz. 1] Ordo [...] Anno Domini 1888 [...], Cracoviae 1888, sumptibus Conventus Augustinianorum, Typis Universitatis Jagellonicae, provisore A. M. Kosterkiewicz, $18 \mathrm{~cm}$., 50 ss.

Treść: jak w poz. 1. 
[cz. 2] Schematismus [...] pro anno 1888 [...], Cracoviae 1888, Typis Universitatis Jagellonicae, provisore A. M. Kosterkiewicz, s. 41-50.

Treść: jak w poz. 7.

Uwagi: tytuł schematyzmu, jak w poz. 19 ze zmianą - [...] p. magistri Pacifici A. Neno [...], na s. 39 napis: „Opera EARP. Sigismundi Wołek STD. bis Exprovincialis, Commissarii Generalis annus XXXIX".

Oprawa: papier, miękka, napis: „Ordo divini officii $1888^{\prime \prime}$.

Sygn.: KUL V-10533/1888 - kalendarz. KUL V-10533A/1888 - kalendarz i schematyzm.

$$
\text { E. }- \text {, L. - }
$$

23. [cz 1] Ordo [...] Anno Domini 1889 [...], Cracoviae 1889, sumptibus Conventus Augustinianorum, Typis Universitatis Jagellonicae, provisore A. M. Kosterkiewicz, 53 ss.

Treść: jak w poz. 1, Scitu necessaria, Reflexio salutaris.

[cz. 2] Schematismus patrum, fratrum et monialium Ordinis Eremitarum S.P. Augustini in Magno Ducatu Cracoviensi pro anno $\mathbf{1 8 8 9}$ sub gloriosissimis auspiciis Reverendissimi p. magistri Pacifici Neno Romani totius S. Ordinis Eremitarum S.P. Augustini generalis, etc., Cracoviae 1889, [b.w.], Typis Universitatis Jagellonicae, provisore A. M. Kosterkiewicz, s. 43-53.

Treść: jak w poz. 7.

Uwagi: zmiana tytułu schematyzmu w stosunku do poz. 19, na s. 39 napis: „Opera EARP. Sigismundi Wołek STD. bis Exprovincialis, Commissarii Generalis annus XL".

Oprawa: papier, miękka, napis: „Ordo divini officii 1889".

Sygn.: KUL V-10533/1889, KUL V$10533 \mathrm{~A} / 1889$.

$$
\text { E. -, L. - }
$$

24. [cz. 1] Ordo [...] Anno Domini 1890 [...], Cracoviae 1890, sumptibus Conventus Augustinianorum, Typis Universitatis Jagellonicae, provisore A. M. Kosterkiewicz, $18 \mathrm{~cm}$., 50 ss.
Treść:jak w poz. 1, Decretum.

[cz. 2] Schematismus patrum, fratrum et monialium Ordinis Eremitarum S.P. Augustini in Magno Ducatu Cracoviensi pro anno 1890 sub gloriosissimis auspiciis Reverendissimi p. fr. Sebastiani Martinelli mag. s. theologiae et prioris generalis, totius Eremitanae Familiae S.P. Augustini electi in capitulo generali Romae in Collegio S. Matris Monicae die 28 Septembris 1889 an., Cracoviae 1890, Typis Universitatis Jagellonicae, provisore A. M. Kosterkiewicz, s. 41-50.

Treść: jak w poz. 7.

Uwagi: zmiana tytułu schematyzmu w stosunku do poz. 23; na s. 38 napis: „Opera EARP. Sigismundi Wołek STD. bis Exprovincialis, Commissarii Generalis annusXLI".

Oprawa: papier wydaw., miękka, napis: „Ordo divini officii 1890".

Sygn.: KUL V-10533/1890, KUL V10533A/1890.

E. cz. 4, t. III, s. 304 (kalendarz); cz. 4, t. IV, s. 123 (schematyzm).

25. [cz. 1] Ordo [...] Anno Domini 1891 [...], Cracoviae 1891, sumptibus Conventus Augustinianorum, Typis Universitatis Jagellonicae, provisore A. M. Kosterkiewicz, 51 ss.

Treść:jak w poz. 1.

[cz. 2] Schematismus [...] pro anno 1891 [...], Cracoviae 1891, Typis Universitatis Jagellonicae, provisore A. M. Kosterkiewicz, s. 41-51.

Treść: jak w poz. 5 .

Uwagi: na s. 38 napis: „Opera EARP. Sigismundi Wołek STD. bis Exprovincialis, Commissarii Generalis annus XLII".

Oprawa: papier wydaw., miękka, napis: „Ordo divini officii 1890".

Sygn.: KUL V-10533/1891 - schematyzm. KUL V-10533A/1891.

E. -, L. -

26. [cz. 1] Ordo divini officii recitandi sacrique peragendi Anno Domini bissextili 1892 a patribus ac fratribus Ordinis Eremi- 
tarum S.P. Augustini Conventus Cracoviensis, Cracoviae 1892, sumptibus PP. Augustinianorum, E Typografia Związkowa sub directione A. Szyjewski, 19 cm., 36 ss.

Treść: jak w poz. 1.

Uwagi: zmiana tytułu kalendarza w stosunku do poz. 3.

Oprawa: papier, miękka, napis jak na str. tyt.

Sygn.: KUL V-10533A/1892.

E. -, L. -

27. [cz. 1] Ordo [...] Anno Domini 1893 [...] Cracoviae 1893, sumptibus PP. Augustinianorum, E Typografia Związkowa, sub directione A. Szyjewski, $18 \mathrm{~cm}$, 53 ss.

Treść: jak w poz. 1.

[cz. 2] Schematismus [...] pro anno 1893 [...], Cracoviae 1893, sumptibus PP. Augustinianorum, E Typografia Związkowa sub directione A. Szyjewski, s. 40-53.

Treść: jak w poz. 5, Conspectus conventuum Ordin. Eremiatarum S.P. Augustini [...], Catalogus ven. patrum Ordin. Erem. S.P. Augustini Provinciae Polonae, Necrologia patrum et fratrum [...] provinciae Polonae $[\ldots]$ post cassationem $[\ldots]$.

Oprawa: papier wydaw., miękka, napis jak na str. tyt.

Sygn.: KUL V-10533/1893, KUL V10533A/1893.

E. -, L. -

28. [cz. 1] Ordo divini officii recitandi sacrique peragendi pro fratribus Ordin. Eremit. S.P. Augustini Conventus Cracoviensis juxta ritum S.R.E. et Brev. ac Missal. Aug. jussu Adm. Rdi patris fr. Augustini Sutor commissarii generalis dispositus et editus Anno Domini MDCCCXCIV [1894], Cracoviae 1894, sumptibus PP. Augustinianorum, E Typografia Związkowa, sub directione A. Szyjewski, 19 cm., 50 ss.

Treść: jak w poz. 1.

Uwagi: zmiana tytułu kalendarza w stosunku do poz. 26.

Oprawa: papier, miękka, napis jak na str. tyt.

Sygn.: KUL V-10533A/1894.
E. - , L. -

29. [cz. 1] Ordo [...] Anno Domini MDCCCXCV [1895], Cracoviae 1895, sumptibus PP. Augustinianorum, E Typografia Związkowa, sub directione A. Szyjewski, $18 \mathrm{~cm} ., 34$ ss.

Treść: jak w poz. 1.

Oprawa: papier, miękka, napis jak na str. tyt.

Sygn.: KUL V-10533A/1895.

E. -, L. -

30. [cz. 1] Ordo divini officii recitandi sacrique peragendi Anno Domini bissextili 1896 a patribus ac fratribus Ord. Erem. S.P. Augustini Conventus Cracoviensis juxta ritum S.R.E. et Brev. ac Missal. Aug. jussu Adm. Rdi patris fr. Augustini Sutor commissarii generalis dispositus et editus, Cracoviae 1896, sumptibus PP. Augustinianorum, E Typografia Związkowa, sub directione A. Szyjewski, 18 cm., 39 ss.

Treść: jak w poz. 1, Varia Decreta [...].

Uwagi: zmiana tytułu kalendarza w stosunku do poz. 28.

Oprawa: papier, miękka, napis jak na str. tyt.

Sygn.: KUL V-10533A/1896.

E. - , L. -

31. [cz. 1] Ordo divini officii recitandi sacrique peragendi pro fratribus ac monialibus Ordinis Eremitarum S.P. Augustini juxta ritum S.R.E. et Brev. ac Missal. Augustinianorum jussu A.R.P. fr. Augustini Sutor Provinciae Polonae praefati Ordinis, commissarii generalis, dispositus et editus Anno Domini MDCCCXCVII [1897], Cracoviae 1897, sumptibus PP. Augustinianorum, E Typografia Związkowa, sub directione A. Szyjewski, 18 cm., 39 ss.

Treść: jak w poz. 1.

Uwagi: zmiana tytułu kalendarza w stosunku do poz. 30.

Oprawa: papier, miękka, napis jak na str. tyt.

Sygn.: KUL V-10533A/1897.

E. -, L. - 
32. [cz. 1] Ordo [...] Anno Domini MDCCCXCVIII [1898], Cracoviae 1898, sumptibus PP. Augustinianorum, E Typographia Związkowa, sub directione A. Szyjewski, 19 cm., 38 ss., [1] k.

Treść: jak w poz. 1.

Oprawa: papier, miękka, napis jak na str. tyt.

Sygn.: KUL V-10533A/1898.

E. - L. -

33. [cz. 2] Schematismus patrum, fratrum et monialium Ordinis Eremitarum S. P. Augustini in Magno Ducatu Cracoviensi pro anno 1898, sumptibus PP. Augustinianorum, Cracoviae, E Typographia Związkowa, sub directione A. Szyjewski, $19 \mathrm{~cm}$., 12 ss., [1] k.

Treść: jak w poz. 8 , Conspectus conventuum $[\ldots]$.

Uwagi: zmiana tytułu schematyzmu w stosunku do poz. 24.

Oprawa: papier, miękka, napis jak na str. tyt.

Sygn.: KUL V-10533/1898.

E. - , L. -

34. [cz. 1] Ordo [...]. Anno Domini MDCCCXCIX [1899], Cracoviae 1899, sumptibus PP. Augustinianorum, E Typografia A. Koziański, 18 cm., 35 ss.

Treść: jak w poz. 1.

Uwagi: tytuł kalendarza, jak w poz. 31 ze zmianą - zamiast: [...] pro fratribus ac monialibus Ordinis Eremitarum S.P. Augustini [...] jest: [...] pro fratribus ac monialibus Convent. Cracovien. Ordinis Eremitarum S.P. Augustini [...].

Oprawa: papier, miękka, napis jak na str. tyt.

Sygn.: KUL V-10533A/1899.

E. - L. -

35. [cz. 1] Ordo [...]. Anno Domini MDCCCC [1900], Cracoviae 1900, sumptibus PP. Augustinianorum, E Typographia A. Koziański, 20 cm., 37 ss., [1] k.

Treść: jak w poz. 1.

Uwagi: tytuł kalendarza, jak w poz. 31 ze zmianą - zamiast: [...] pro fratribus ac monialibus Ordinis Eremitarum S.P. Augustini [...] jest: [...] pro fratribus ac monialibus Convent. Cracovien. Ordinis Eremita- rum S.P. Augustini [...].

Oprawa: papier, miękka, napis podobny jak na str. tyt. (uproszczony)

Sygn.: KUL V-10533A/1900.

E. -, L. -

36. [cz. 1] Ordo divini officii recitandi sacrique peragendi servandus Anno Domini MCMI [1901] a fratribus ac monialibus Ordinis Eremitarum S.P. Augustini Conv. Cracov. juxta ritum S.R.E. et Brev. ac Missal. Augustin. jussu A.R.P. Fr. Augustini Sutor Provinciae Polonae praefati Ordinis, commissarii generalis, dispositus et editus, Cracoviae 1901, sumptibus PP. Augustinianorum, Typis V. L. Anczyc et Consortium, $19 \mathrm{~cm} ., 40 \mathrm{ss}$.

Treść: jak w poz. 1.

[cz. 2] [Schematismus], s. 37-40.

Treść: jak w poz. 5 .

Uwagi: zmiana tytułu kalendarza w stosunku do poz. 31.

Oprawa: papier, miękka, napis podobny, jak na str. tyt.

Sygn.: KUL V-10533A/1901.

E. - , L. -

37. [cz. 2] Status Fratrum Ordinis Eremitarum S.P. Augustini in Provincia Bavarico-Germanica et Polonica mense oktobri 1906, Münnerstadt, Typis G. Blatz, $18 \mathrm{~cm}$., $28,[3]$ ss.

Treść: władze zakonu, właze prowincji, wykaz zakonników według domów zakonnych, w tym domu zakonnego w Krakowie, zestawienie liczby zakonników, indeks alfabetyczny zakonników według daty wstąpienia do zakonu, indeks alfabetyczny braci laików według daty wstąpienia do zakonu, wykaz zmarłych, wykaz sióstr zakonnych domu zakonnego żeńskiego w Krakowie.

Uwagi: zmiana tytułu schematyzmu w stosunku do poz. 37.

Oprawa: papier, miękka, napis podobny, jak na str. tyt.

Sygn.: KUL V-10533A/1906.

E. -, L. - 
38. [cz. 2] Fratrum et monialium Ordinis Eremitarum S. Augustini catalogus Provinciae Polonicae canonice erectae 1546 anno pro anno 1933/34 jussu Adm. rev. p. fr. Gregorii Uth commissarii provincialis concinnatus et editus, Cracoviae [1933], [b.w.], Typis Officinae W. L. Anczyc, 19 cm., 16 ss.

Treść: władze zwierzchnie, skład osobowy poszczególnych domów zakonnych, Catalogus patrum et fratrum clericorum [...], Catalogus fratrum laicorum [...], Dies onomastici, Defuncti (1903-1933), taki sam układ domu zakonnego żeńskiego

Uwagi: zmiana tytułu schematyzmu w stosunku do poz. 33.

Oprawa: papier wydaw., miękka, napis jak na str. tyt.

Sygn.: KUL V-10533/1933/34.

E. -, L. -

\section{BAZYLIANIE}

Zakon św. Bazylego Wielkiego (Ordo Sancti Brasilii Magni-OSBM).

Pierwotną regułę bazylianów stworzył w IV w. Bazyli Wielki, dając tym samym początek intensywnemu rozwojowi życia zakonnego.

W Polsce, szczególne znaczenie zakonu wzrosło po Unii Brzeskiej (1596 r.). To właśnie $\mathrm{z}$ tej formacji wywodzili się biskupi, wyżsi urzędnicy kościelni, teologowie czy kaznodzieje Kościoła unickiego. W 1743 r. został utworzony, wskutek zjednoczenia litewskiej i polskiej (ruskiej) kongregacji Zakon Bazylianów św. Jozafata (Ordo Basilianus Sancti Josephi), a kongregacje przemianowano na prowincje.

W wyniku rozbiorów, znaczną część klasztorów bazyliańskich, które znalazły się na terenie państwa rosyjskiego skasowano, a pozostałe zobowiązane zostały do przyjęcia rytu prawosławnego.

Odmiennie wyglądała sytuacja bazylianów pod zaborem austriackim. Już w roku 1780 wydzielono prowincję galicyjską pw. Najświętszego Zbawiciela. W latach 80. XIX w. zakon został objęty reformą kierowaną przez jezuitów. Dzięki niej możliwe było przejmowanie klasztorów oraz erygowanie nowych placówek.

W 1931 r. zakon podzielono na prowincje. Jedną z nich, obejmującą zimie polskie była wspomniana już prowincja galicyjska, która rok później otrzymała wezwanie św. Jozafata.

1. [cz. 2] Шиматисмъ честнаго духовства чина св. Васілія В. въ Галиціи на годъ 1856, Львовъ 1856, [b.w.] Туцомъ [!] Института Ставропигіянскаго, 22 cm., 14 ss.

Treść: przełożony Zakonu, skład osobowy poszczególnych monasterów, zestawienie liczby zakonników zakonników, wykaz zmarłych.

Uwagi: jęz. starocerkiewno-słowiański.

Oprawa: paper wydaw., miękka, napis jak na str. tyt.

Sygn.: KUL V-1217/1856.

E. -, L. -, Z. poz. 54 .

2. [cz. 2] Шиматисмъ чина св. Васілія В. въ Галиціи на годъ 1857 , Львовъ 1857, [b.w.] Тупомъ Института Ставропигіянскаго, 22 cm., 21 ss., [1] k.

Treść: przełożony i władze Zakonu, krótka historia poszczególnych monasterów, skład osobowy poszczególnych monasterów, zestawienie liczby zakonników zakonników, wykaz zmarłych, skład osobowy żeńskich monasterów.

Proweniencja: pieczęć, napis nieczytelny.

Uwagi: zmiana tytułu schematyzmu w stosunku do poz. 1 ; jak w poz. 1 .

Oprawa: jak w poz. 1.

Sygn.: KUL V-1217/1857.

E. -, L. -, Z. poz. 54 .

3. [cz. 2] Шематисмъ монастырей чина св. Василія В. въ Галиціи на годъ 1859. Съ исправленными историческими примбчачіаями, Львовъ 1859, [b.w.] Тvпомъ Института Ставропигіянскаго, $22 \mathrm{~cm} ., 32 \mathrm{ss}$.

Treść: przełożony Zakonu, obszerna historia poszczególnych monasterów, skład osobowy poszcze- 
gólnych monasterów (w tym żeńskich), zestawienie liczby zakonników zakonników, wykaz zmarłych.

Proweniencja: pieczęć, napis nieczytelny.

Uwagi: zmiana tytułu schematyzmu w stosunku do poz. 2; jak w poz. 1 .

Oprawa: jak w poz. 1.

Sygn.: KUL V-1217/1859.

E. -, L. -, Z. poz. 54 .

4. [cz. 2] Шематисмъ провинціи св. Спасителя Чина св. Василія Великого въ Галиціи, уложеный по капитулъ оิтбувшоิйся въ монастыръ св. Онуфрейскомъъ во Львовъ дня 24 и 25 Липця 1866 и короткій поглядъ на монастыри и на монашество руске, оิтъ заведеня на Руси въры Христовои ажъ по нынъшное время, во Львове 1867, [b.w.], Въ типографіи Института Ставронигіанского, по́дъ зарядомъ Сшефана Гучковского, 25 cm., 352, [2] ss.

Treść: przełożony Zakonu, władze Zakonu, obszerna historia poszczególnych monasterów, statystyka osobowa, krótki rys historyczny dotyczący monasterów i życia monastycznego.wraz z monasterami wchodzącymi w skład poszczególnych eparchiiskład osobowy poszczególnych monasterów.

Uwagi: zmiana tytułu schematyzmu w stosunku do poz. 3 ; jak w poz. 1 .

Oprawa: jak w poz. 1.

Sygn.: KUL V-1217/1867.

E. - , L. - , Z. -

5. [cz. 2] Шематисмъ иноковъ чина св. Василія Великаго, угорскія области, на годъ 1870 (Съ короткимъ историческимъ очеркомъ монастырей тойже области; - составленъ по отбывшемся въ Краснобродскомъ монстыр, 13 (25) іюня 1869 года всеобщем Собор, Унгваръ 1869, [b.w.], Типогрфія вдовы Карла Іегера, 20 cm., 16 ss.

Treść: przełożony Zakonu, władze Zakonu, obszerna historia poszczególnych monasterów, skład osobowy poszczególnych monasterów.

Uwagi: zmiana tytułu schematyzmu w stosunku do poz. 4; jak w poz. 1.

Oprawa: jak w poz. 1.

Sygn.: KUL V-1217/1870.

E. - , L. - , Z. -

6. [cz. 2] Catalogus Ordinis S. Basilii Magni Reformationis Dobromiliensis sub regimine PP. Soc. Jesu anno 1894, Cracoviae 1894, [sumptibus PP. Basilianorum], Ex Typographia Ephemeridum „Czas” Fr. Kluczycki \& Soc., provisore Josepho Łakociński, $23 \mathrm{~cm} ., 13$ ss., [1] k.

Treść: skład osobowy poszczególnych monasterów, zestawienie liczby zakonników zakonników.

Proweniencja: na str. tyt. pieczęcie z napisami: 1. „Бібліотека гр. кат. капітули в Перемишлі ч ....”; 2. Бібліотека Епископа Перемыского Дра. Юліана Пелеа Чо.........”, ‘1415 XX.55.” -niebieską kredką.

Uwagi: zmiana tytułu schematyzmu w stosunku do poz. 4; adres wydawniczy uzupełniony z treści schematyzmu.

Oprawa: jak w poz. 1.

Sygn.: KUL V-1217/1894.

E. -, L. -, Z. poz. 54 .

7. [cz. 2] Catalogus [...] anno 1895, Cracoviae 1895, [sumptibus PP. Basilianorum], Ex Typographia Ephemeridum „Czas” Fr. Kluczycki \& Soc., provisore Josepho Łakociński, 21 cm., 14 ss., [1] k.

Treść: skład osobowy poszczególnych monasterów, zestawienie liczby zakonników zakonników zestawienie liczby zakonników, Vita functi.

Proweniencja: jak w poz. 5 .

Uwagi: jak w poz. 5.

Oprawa: jak w poz. 1.

Sygn.: KUL V-1217/1895.

E. - , L. - , Z. -

8. [cz. 2] Catalogus [...] anno 1896, Żółkieviae 1896, [sumptibus PP. Basilianorum], Ex Typographia PP. Basilianorum, provisore Francisco Sarnicki, $20 \mathrm{~cm}$., 20 ss.

Treść: jak w poz. 6 .

Proweniencja: jak w poz. 5, pieczęć nr 1 .

Uwagi: jak w poz. 5.

Oprawa: jak w poz. 1. 
Sygn.: KUL V-1217/1896.

E. -, L. -, Z. poz. 54 .

9. [cz. 2] Catalogus [...] anno 1898, Żółkieviae 1898, [b.w.], Ex Typographia PP. Basilianorum, 19 cm., 24 ss.

Treść: przełożony Zakonu, skład osobowy poszczególnych monasterów, zestawienie liczby zakonników zakonników, Index monachorum.

Proweniencja: jak w poz. 5, pieczęć nr 1 .

Oprawa: tektura, twarda.

Sygn.: KUL V-1217/1898.

E. - , L. - , Z. -

10. [cz. 2] Catalogus [...] anno 1899, Żółkieviae 1899, [b.w.], Ex Typographia PP. Basilianorum, 19 cm., 27 ss.

Treść: jak w poz. 8.

Proweniencja: jak w poz. 5, pieczęć nr 1 .

Oprawa: tektura, twarda.

Sygn.: KUL V-1217/1899.

E. - , L. - , Z. -

11. [cz. 2] Catalogus [...] anno 1900, Żółkieviae 1900, [b.w.], Ex Typographia PP. Basilianorum, $19 \mathrm{~cm} ., 31 \mathrm{ss}$.

Treść: przełożony Zakonu, skład osobowy poszczególnych monasterów, zestawienie liczby zakonników zakonników, Index monachorum władze Zakonu, Vita functi.

Proweniencja: jak w poz. 5, pieczęć nr 1 .

Oprawa: jak w poz. 1.

Sygn.: KUL V-1217/1900.

E. -, L. - Z. -

12. [cz. 2] Catalogus [...] anno 1902 (in Galicia), Żółkieviae 1902, [b.w.], Typographia PP. Basilianorum, $20 \mathrm{~cm}$., 40 ss.

Treść: jak w poz. 10.

Uwagi: tytuł uzupełniony $\mathrm{z}$ treści schematy$\mathrm{zmu}$.

Oprawa: oprawa introligatorska, tektura, półmateriał, twarda, złocony napis: „1902”.

Sygn.: KUL V-1217/1902.

E. -, L. -, Z. -

13. [cz. 2] Catalogus [...] ineunte anno MCMIII [1903] (in Galicia), Żółkie- viae 1903, [b.w.], Typographia PP. Basilianorum, $22 \mathrm{~cm}$., $45 \mathrm{ss} .$, [2] kk.

Treść: jak w poz. 10.

Proweniencja: jak w poz. 5, pieczęć nr 1 .

Uwagi: tytuł uzupełniony $\mathrm{z}$ treści schematyzmu.

Oprawa: oprawa introligatorska, tektura, półmateriał, twarda, złocony napis: „1903” oraz złocone brzegi kart.

Sygn.: KUL V-1217/1903.

E. -, L. -, Z. poz. 54 .

14. [cz. 2] Catalogus [...] ineunte anno MCMIV [1904] (in Galicia), Żółkieviae 1904, [b.w.], Typographia PP. Basilianorum, $22 \mathrm{~cm} ., 42$ ss., [2] kk.

Treść: jak w poz. 10.

Proweniencja: jak w poz. 5, pieczęć nr 1 .

Uwagi: tytuł uzupełniony $\mathrm{z}$ treści schematyzmu.

Oprawa: oprawa introligatorska, tektura, półmateriał, twarda, złocony napis: „1904” oraz złocone brzegi kart..

Sygn.: KUL V-1217/1904.

E. - , L. - , Z. -

15. [cz. 2] Catalogus Ordinis S. Basilii Magni anno MCMV [1905] et MCMVI [1906] (in Galicia), Zovkva 1905, [b.w.], Typographia PP. Basilianorum, 23 cm., 41 ss., [1] k.

Treść: jak w poz. 10, In missionius extra Europam.

Uwagi: zmiana tytułu schematyzmu w stosunku do poz. 5 ; tytuł uzupełniony z treści schematyzmu.

Oprawa: jak w poz. 1.

Sygn.: KUL V-1217/1905/1906.

E. -, L. -, Z. poz. 54 .

16. [cz. 2] Catalogus Ordnis S. Basilii Magni Congregationis Ruthenae SS. Salvatoris (in Galicia) in annum MCMIX [1909], Żovkva 1908, [b.w.], Typographia PP. Basilianorum, 23 cm., 46 ss., [1] k.

Treść: jak w poz. 10, Professi votorum solemnium.

Proweniencja: jak w poz. 5, pieczęć nr 1 .

Uwagi: zmiana tytułu schematyzmu w stosunku 
do poz. 15; tytuł uzupełniony z treści schematyzmu. Drugi egzemplarz z tego roku- oprawa - papier wydaw., brak tylnej okładki.

Oprawa: oprawa introligatorska, tektura, półmateriał, twarda, złocony napis: „Catalogus Ord. S. Basilii Magni 1909” oraz złocone brzegi kart.

Sygn.: KUL V-1217/1909.

E. -, L. -, Z. poz. 54 .

17. [cz. 2] Catalogus [...] in annum MCMX [1910], Żovkva 1909, [b.w.], Typographia PP. Basilianorum, $22 \mathrm{~cm} ., 44$ ss.

Treść: jak w poz. 11, Ordo Regimine hegumenorum.

Proweniencja: jak w poz. 5, pieczęć nr 1, pieczęć nr 2 z napisem:

Переплетня Семъратовича Ормянская ч. I. „Народний Домъ” въ Лъвовъ

Uwagi: uzupełnienie tytułu z treści schematyzmu.

Oprawa: oprawa introligatorska, tektura, półmateriał, twarda, złocona oprawa oraz tytuł: „Catalogus Ordinis S. Basilii Magni 1910”.

Sygn.: KUL V-1217/1910.

E. - , L. - , Z. -

18. [cz. 2] Catalogus [...] in annum MCMXI [1911], Żovkva 1910, [b.w.], Typographia PP. Basilianorum, $23 \mathrm{~cm}$., 44 ss., [1] k.

Treść: jak w poz. 11, Status Provinciarum.

Proweniencja: jak w poz. 5, pieczęć nr 1 .

Uwagi: uzupełnienie tytułu $\mathrm{z}$ treści schematyzmu.

Oprawa: tektura, półmateriał, twarda, złocone brzegi oraz tytuł: „Catalogus Ord. S. Brasilii Magni 1911 ".

Sygn.: KUL V-1217/1911.

E. - , L. - , Z. -

19. [cz. 2] Catalogus [...] in annum MCMXII [1912], Żovkva 1911, [b.w.], Typographia PP. Basilianorum, 22 cm., 48 ss., [1] k., egz. intefol. [25] kk.

Treść: jak w poz. 11

Proweniencja: jak w poz. 5 pieczęć nr 1 .

Uwagi: uzupełnienie tytułu $\mathrm{z}$ treści schematyzmu.
Oprawa: oprawa introligatorska, tektura, pó1materiał, twarda, złocone brzegi oraz tytuł: „Catalogus Ord. S. Basilii Magni 1912”.

Sygn.: KUL V-1217/1912.

E. -, L. -, Z. -

20. [cz. 2] Catalogus [...] in annum MCMXVII [1917] (in Galicia \{tempore belli\}), Żovkva 1916, [b.w.], Typographia PP. Basilianorum, 23 cm., 44 ss.

Treść: jak w poz. 11, Vita functi 1914-1916.

Uwagi: uzupełnienie tytułu z treści schematyzmu.

Oprawa: jak w poz. 1

Sygn.: KUL V-1217/1917.

E. - , L. - , Z. -

21. [cz. 2] Catalogus Ordnis S. Basilii Magni Provinciae SS. Salvatoris ineunte anno MCMXXVI [1926], Żovkva 1926, [b.w.], Typographia PP. Basilianorum, 23 cm., 56 ss.

Treść: jak w poz. 11, Ordo Regiminie.

Uwagi: zmiana tytułu schematyzmu w stosunku do poz. 16.

Oprawa: tektura, półmateriał, twarda, złocone brzegi oraz tytuł: „Catalogus Ord. S. Brasilii Magni 1911 ".

Sygn.: KUL V-1217/1926.

E. -, L. -, Z. poz. 54 .

22. [cz. 2] Catalogus Provinciae SS. Salvatoris Ordnis Basiliani s-ti Iosephat ineunte anno 1934, Żovkva 1934, [b.w.], Typographia PP. Basilianorum, $23 \mathrm{~cm}$., $60 \mathrm{ss}$.

Treść: jak w poz. 11, dane dotyczące zakonników z innych państw.

Uwagi: zmiana tytułu schematyzmu w stosunku do poz. 16 .

Oprawa: jak w poz. 1.

Sygn.: KUL V-1217/1926.

E. -, L. -, Z. poz. 54 .

23. [cz. 2] Catalogus Ordnis Basiliani s-ti Iosephat Provinciae ss. Salvatoris ineunte anno 1935, Żovkva 1935, [b.w.], Typographia PP. Basilianorum, $23 \mathrm{~cm}$., 64 ss.

Treść: jak w poz. 22. 
Uwagi: zmiana tytułu schematyzmu w stosunku do poz. 21; 2 egz. - ma twardą oprawę introligatorską ze złoconym tytułem podobnym, jak na str. tyt.

Oprawa: jak w poz. 1.

Sygn.: KUL V-1217/1926.

E. -, L. -, Z. poz. 54 .

24. [cz. 2] Catalogus [...] ineunte anno 1936, Żovkva 1935, [b.w.], Typographia PP. Basilianorum, $23 \mathrm{~cm}$., 68 ss.

Treść: jak w poz. 10.

Proweniencja: na str. tyt. pieczęć z napisem: „Biblioteka Pisarzy Tow. Jez. W Warszawie” 4171.

Oprawa: jak w poz. 1.

Sygn.: KUL V-1217/1926.

E. - , L. - , Z. -

25. [cz. 2] Catalogus [...] ineunte anno 1937, Żovkva 1937, [b.w.], Typographia PP. Basilianorum, 23 cm., 53 ss., [1] k.

Treść: jak w poz. 10.

Proweniencja: na str. tyt. napis atramentem: „X. Br. Ussas 1785”.

Oprawa: jak w poz. 1.

Sygn.: KUL V-1217/1926.

E. -, L. - Z. -

26. [cz. 2] Catalogus [...] ineunte anno 1938, Żovkva 1938, [b.w.], Typographia PP. Basilianorum, 23 cm., 54 ss., [2] kk.

Treść: jak w poz. 10, spis treści.

Proweniencja: na str. tyt. napis atramentem: „X. Br. Ussas 1785”.

Uwagi: z tyłu napis: „Typis editus 20 ian 1938”, miejsce na notatki z tyłu schematyzmu.

Oprawa: tektura, półmateriał, twarda, złocony napis tytułu podobny jak na str. tyt.

Sygn.: KUL V-1217/1926.

E. -, L. -, Z. poz. 54 .

\section{BERNARDYNI}

Bracia Mniejsi Regularnej Obserwancji (Fratres Minores Regularis Observantiae - OFM).

W XV w. wyodrębniła się z Zakonu
Braci Mniejszych (franciszkanów) grupa dążąca do przestrzegania ścisłego ubóstwa, zwana Obserwantami. W 1517 r. zostali oni uznani za samodzielny zakon.

W Polsce, obserwanci pierwszy klasztor pw. św. Bernardyna ze Sieny (stąd też nazwa bernardyni) założyli w $1453 \mathrm{r}$. w Krakowie.

Do czasu I rozbioru na obszarze Rzeczypospolitej istniały 4 prowincje bernardyńskie: małopolska pw. Wniebowzięcia NMP, wielkopolska pw. Matki Boskiej Anielskiej, ruska pw. Niepokalanego Poczęcia NMP, litewska pw. św. Kazimierza. Po 1772 r. nastąpiły wielokrotnie zmiany granic prowincji i przynależności poszczególnych klasztorów. Ze względu na obszerność zagadnienia, w niniejszym tekście zostanie przestawiony jedynie ogólny zarys historii prowincji, których schematyzmy znajdują się w zbiorze BU KUL.

Directorium z 1838 r. sporządzone zostało dla klasztorów prowincji litewskoruskiej (III.1) funkcjonującej na ziemiach przyłączonych do Cesarstwa Rosyjskiego. Po roku 1830 domy z tego terenu uległy systematycznej kasacie, dlatego zapewne w tytule kalendarza nie używano prawnego nazewnictwa prowincji.

$\mathrm{Na}$ ziemiach I zaboru austriackiego, $\mathrm{z}$ istniejących tam klasztorów utworzono prowincję galicyjską „Bł. Jana z Dukli pod opieką Niepokalanie Poczętej NMP" (1785 rok). Od 1795 r. określana ona była jako wschodnio-galicyjska, dla odróżnienia jej od działającej w granicach państwa austriackiego od III rozbioru prowincji małopolskiej, od 1799 r. nazywanej Zachodniogalicyjską (III.2).

W 1806 r. obydwie jednostki administracyjne zostały połączone tworząc prowincję Wschodniej i Zachodniej Galicji, zwaną też prowincją Obojga Galicji (III.3). Tym samym w granicach jednej jednostki administracyjnej znalazły się klasztory przedrozbiorowej prowincji małopolskiej i ruskiej.

W 1810 r. ponownie dokonano jej podziału. Na kapitule w Radecznicy, klaszto- 
ry prowincji zachodnio-galicyjskiej przyłączono do reaktywowanej w ramach Księstwa Warszawskiego prowincji małopolskiej (III.4). Stan ten trwał do 1864 r., kiedy to $\mathrm{w}$ wyniku polityki kasacyjnej władz carskich zlikwidowano stopniowo niemal wszystkie klasztory bernardyńskie (na terenie Królestwa Polskiego do 1919 r. przetrwał jedynie konwent w Kole należący do prowincji wielkopolskiej).

Po wspomnianym podziale prowincji Obojga Galicji, jaki miał miejsce w roku 1810, na kapitule w Leżajsku ukonstytuowano stan dla prowincji galicyjskiej pw. Niepokalanego Poczęcia NMP (III.5). Była to jedyna jednostka administracyjna, która przetwała do odzyskania przez Polskę państwowości. Dodatkowo, od lat 80 . XIX w. stopniowo zaczęła się rozwijać m. in. tworząc liczne ekspozytury duszpasterskie.

W roku 1899 nastąiło faktyczne zjednoczenie prowincji galicyjskich zakonu bernardynów i reformatów. Podstawą była decyzja papieża Leona XIII wyrażona w bulli ,Felicitate quadam” z 1897 r. jednocząca wszystkie odłamy obserwnckie franciszkanów w jedną formację pod wspólną nazwą Braci Mniejszych. Stan ten w Polsce trwał do 1911 r., kiedy to dekretem Stolicy Apostolskiej przywrócono prowincje polskie sprzed połączenia tych dwóch gałęzi zakonu.

W 1918 r. prowincja galicyjska bernardynów, zachowując dotychczasowy tytuł Niepokalanego Poczęcia NMP, przyjęła nazwę polskiej (III.6. Prowincja polska). Objęła ona swym zasięgiem obszar całej Rzeczypospolitej odzyskując utracone w skutek kasat klasztory oraz tworząc nowe placówki. Obecnie jest jedną z pięciu prowincji Braci Mniejszych w Polsce.

W ninejszym zestawieniu dokonano próby periodyzacji poszczególnych druków.

\section{III.1. PROWINCJA LITEWSKO -RUSKA (po 1816)}

1. [cz. 1] Directorium horarum canonicarum et missarum juxta ritum S.R.E. et rubricas Breviarii et Missalis Romano Seraphici pro Fratribus Minoribus de Observantia et Monialibus Tertii Ordinis S.P.N. Francisci caeterisque confratribus eodem breviario et missali utentibus in Dioecesibus Mohiloviensi, Vilnensi, Minscensi, Samogitiensi, Luceoriensi existentibus pro Anno Domini 1838 in modum kalendarii julianii dispositum, Vilnae 1837, [b.w.], Typis Basilianis, $17 \mathrm{~cm}$., [207] ss.

Treść: zasadniczy zrąb kalendarza, modlitwy, Notae Scitu Necessariae.

[cz. 1a] Tabula patrum ac fratrum Ordinis N. mortuorum [...], s. [166-167].

[cz. 2] Elenchus cleri regularis Ordinis Minorum S.P.N. Francisci Observantium anno 1837 mensis Novembris 28 die, Vilnae 1837, Typis Basilianis, c.d. s. [182207].

Treść: władze prowincji, alfabetyczny spis zakonników, skład osobowy poszczególnych domów zakonnych żeńskich.

Proweniencja: napis atramentem „Fr. Stanislaus Ivo Ciechanowicz Ordis S.P. Fr. Observantium”.

Uwagi: pismem odręcznym dopisani zmarli.

Oprawa: papier, miękka.

Sygn.: KUL V-6860/1838.

E. cz. 1, t. I, s. 315, L. -, Z. -

\section{III.2. PROWINCJA ZACHODNIO- GALICYJSKA (1799-1806)}

1. [cz. 1] Directorium divini officii et missae celebrandae juxta rubricas Romano Seraphicas nuper a S. Sede Apostolica revisas \& approbatas ad usum FF. Minorum S.P. Francisci Observantium ac Monialium Provinciae Galliciae Occidentalis, Minoris Poloniae sub titulo Imac. Conceptionis B.V. Mariae pro anno bissextili 1804, Lublini [1803], [b.w.] Typis S.C.R.M. Trynitariorum, $16 \mathrm{~cm}$., [74] ss.

Treść: zasadniczy zrąb kalendarza. 
[cz. 1a] Pia memoria benefactores et tertiarii, s. [73-74].

Treść: wykaz zmarłych zakonników również z Prowincji Galicyjskiej.

Uwagi: notatki atramentem.

Oprawa: papier, miękka.

Sygn.: KUL V-8303/1804.

E. - , L. - , Z. -

2. [cz. 1] Directorium [...] pro Anno Domini 1805, Lublini [1804], [b.w.], Typis S.C.R.M. PP. Trinitariorum, 16 cm., [66] SS.

Treść: jak w poz. 1.

[cz. 1a] Pia memoria [...], s. [64-66].

Treść: jak w poz. 1.

Proweniencja: „Conventus Kustod. Cracoviensis Pacz. 1" - tylna okładka.

Oprawa: papier, miękka, napis czerwoną kredką: ,1805”.

Sygn.: KUL V-8303/1805.

E. - , L. - , Z. -

3. [cz. 1] Directorium divini officii et missarum celebrandarum juxta rubricas Romano Seraphicas, nuper a S. Sede Apostolica revisas \& approbatas ad usum FF. Minorum S.P. Francisci Observantium, ac monialium Provinciae Galliciae Occidentalis sub titulo Imac. Conceptionis B.V. Mariae pro Anno Domini 1806, Lublini [1805], [b.w.], Typis S.C.R.M. PP. Trinitariorum, [76] ss.

Treść: jak w poz. 1, Monitum.

[cz. 1a] Pia memoria [...], s. [74-76].

Treść: jak w poz. 1.

Uwagi: zmiana tytułu kalendarza w stosunku do poz. 1.

Oprawa: papier, miękka, napis atramentem: „Cracoviae 1806”.

Sygn.: KUL V-8303/1806.

E. - , L. - , Z. -

\section{III.3. PROWINCJA OBOJGA GALICJI (1806-1810)}

1. [cz. 1.] Directorium divini officii nec non missarum celebrandarum juxta novum calendarium ac S.R.C. Decreta, atque rubricas Breviarii novissimas a Pio VI P. M. ańo 1785 pontificatus sui ano undecimo ordinatum ad usum FF. Minorum Observantium S.P. Francisci Provinciae in Regnis Galiciae \& Lodomeriae degentium sub titulo Immaculatae Conceptionis B.V. Mariae jussu superiorum pro anno 1807 editum, Cracoviae [1806], [b.w.], Typis Annae Dziedzicka, 16 cm., [64] ss.

Treść: zasadniczy zrąb kalendarza, Lunationes.

[cz. 1a] Pia memoria PP. \& FF. in Domino defunctorum, s. [59-61].

Treść: wykaz zmarłych zakonników również z Prowincji Małopolskiej oraz Ruskiej.

Oprawa: brak.

Sygn.: KUL V-8303/1807.

E. - , L. - , Z. -

2. [cz. 1.] Directorium divini officii nec non missarum celebrandarum juxta calendarium \& rubricas Breviarii novissimas a Pio VI P. M. anno 1785 pontificatus sui anno undecimo approbatas atque S.R.C. Decreta ordinatum ad usum FF. Minorum S.P. Francisci Observantium Provinciae utriusque Galiciae \& Lodomeriae degentium sub titulo Immaculatae Conceptionis B.V. Mariae jussu superiorum pro anno bissextili 1808 editum, Cracoviae [1807], [b.w.], Typis Annae Dziedzicka, 16 cm., [60] ss.

Treść: jak w poz. 1.

[cz. 1a] Pia memoria [...], s. [59-60].

Treść: wykaz zmarłych zakonników również z Prowincji Małopolskiej oraz Rosji.

Proweniencja: „Patris Josephi Mühytron [?] Orbis Minor S.P. Francisci Gradicatoris et Professoris Normas. [?] in Conventu Radomiensi, Die 31 Decemb[ris] 807'.

Uwagi: zmiana tytułu kalendarza w stosunku do poz. 1 .

Oprawa: papier, miękka.

Sygn.: KUL V-8303/1808.

E. -, L. -, Z. - 
3. [cz. 1] Directorium divini officii nec non missarum celebrandarum juxta calendarium \& rubricas Breviarii novissimas a Pio VI P. M. anno 1785 pontificatus sui anno undecimo approbatas atque S.R.C. Decreta ordinatum ad usum Fratrum Minorum S.P. Francisci Observantium, in utraque Galicia degentium, Provinciae sub titulo Immaculatae Conceptionis B.V. Mariae jussu superiorum pro anno communi 1809 editum, Cracoviae [1808], [b.w.], Tipis Annae Dziedzicka, 16 cm., [54] ss.

Treść: jak w poz. 1.

[cz. 1a] Pia memoria [...], s. [53-54].

Treść: wykaz zmarłych zakonników.

Uwagi: zmiana tytułu kalendarza w stosunku do poz. 2, notatki na okładce.

Oprawa: brak.

Sygn.: KUL V-8303/1809.

E. cz. 1, t. I, s.315, L. -, Z. -

4. [cz. 1] Directorium divini officii nec non missarum celebrandarum juxta calendarium \& rubricas Breviarii novissimas a Pio VI P.M. anno 1785 pontificatus sui anno $11 \mathrm{mo}$ approbatas atque S.R.C. Decreta ordinatum ad usum Fratrum Minorum S.P. Francisci Observantium per Provinciam utriusquae Galiciae degentium, sub titulo Immaculata [!] Conceptionis B.V. Mariae pro ao communi 1810 editum, Leopoli [1809], [b.w.], Typis Pillerianis, 18 cm., [62] ss.

Treść: jak w poz. 1.

[cz. 1a] Pia memoria confratres et benefactores, k. [60-62].

Treść: wykaz zmarłych zakonników oraz dobrodziejów.

Proweniencja: „Pro patrem Marco Budkowski [?] Ord. S.P.N. Francisco de Observantia”.

Uwagi: zmiana tytułu kalendarza w stosunku do poz. 3, notatki, oderwana częściowo jedna z kart.

Oprawa: brak.

Sygn.: KUL V-8303/1810.

E. - , L.,- Z. -

5. [cz. 1] Directorium divini officii nec non missarum celebrandarum juxta ca- lendarium et rubricas Breviarii novissimas a Pio 6. P. M. anno 1785 approbatas atque S.R.C. Decreta ordinatum ad usum Fratrum Minorum S.P. Francisci Observantium per Provinciam Galiciae degentium sub titulo Immaculatae Conceptionis B.V. Mariae jussu superiorum pro anno communi 1811 editum, Leopoli [1810], [b.w.], Typis Pillerianis, $17 \mathrm{~cm}$. , [56] ss.

Treść: jak w poz. 1.

Uwagi: zmiana tytułu kalendarza w stosunku do poz. 4; brak ostatnich kart.

Oprawa: brak.

Sygn.: KUL V-8303/1811.

E. -, L. -, Z. -

\section{III.4. PROWINCJA MALOPOLSKA (1810-1864)}

1. [cz. 1] Ordo divini officii recitandi missarumque celebrandarum pro usu Fratrum Minorum Observantium, in Provincia (Minoris Poloniae) degentium, nec non ejusdem Ordinis et Provinaciae Monialium sub titulo ac protectione B.V.M. Immacul. Conceptae militantium juxta novo-ordinatum calendarium, novissimasque rubricas ac Sacrae Rituum Congregationis - Decreta in Annum Domini post embolismalem primum et ipsum bissextilem scilicet $\mathbf{1 8 1 6}$ conscriptus, Cracoviae [1815], [b.w.] Typis Academicis, $17 \mathrm{~cm}$., [42] ss., egz. intefol. [8] kk.

Treść: zasadniczy zrąb kalendarza, Dubium.

[cz. 1a] Pia memoria patrum, fratrum ac benefactorum [...] defunctorum, s. [42].

Uwagi: notatki, dołączona luźna karta z innego druku.

Oprawa: tektura, twarda, notatki na okładce.

Sygn.: KUL V-8303/1816.

E. -, L. -, Z. -

2. [cz. 1] Directorium officii divini ac missae celebrandae juxta rubricas Breviarii, ac Missalis Romano-Seraphici ad usum Fratrum Minorum S.P. Francisci Observantium, Monialium ac Tertii Ordinis confra- 
trum Provinciae Minoris Poloniae sub titulo at protectione SS. Virginis Mariae Immaculatae titularis totius Ordinis et Provinciae Patronae pro anno Christi 1819 conscriptum, Cracoviae [1818], [b.w.] Typis Academicis, $18 \mathrm{~cm}$., $42 \mathrm{ss}$.

Treść: jak w poz. 1.

[cz. 1a] Pia memoria patrum, fratrum [...] defunctorum, s. 41-42.

Treść: jak w poz. 1.

Uwagi: zmiana tytułu kalendarza w stosunku do poz. 1.

Oprawa: brak.

Sygn.: KUL V-8303/1819.

E. - , L. - , Z. -

3. [cz. 1] Directorium divini officij [!] recitandi missarumque celebrandarum pro usu [!] Fratrum Minorum Observantium, Provinciae Minoris Poloniae; nec non ejusdem Ordinis etc. monialium sub titulo ac protectione B.V. Mariae Immacul. Conceptae [!], militantium juxta novo ordinatum calendarium, novissimasque rubricas, ac Srae Rituum Congregationis - Decreta in annum 1825 conscriptum, Siedlcensi [1825], [b.w.], Superiorum permissu in Typographia Dni Stanislai Pruski, 20 cm., 55 ss.

Treść: jak w poz. 1.

[cz. 1a] Pia memoria partum ac ffrum nostrae Provinicae in Dno defunctorum [...] nec non benefactor. confratrumque nostror Tertii Ordinis, s. 54-55.

Uwagi: zmiana tytułu kalendarza w stosunku do poz. 2.

Oprawa: tektura, twarda, napis ołówkiem: ,1825”.

Sygn.: KUL V-8303/1825.

E. - , L. - , Z. -

4. [cz. 1] Directorium divini officii celebrandi missarumque celebrandarum pro usu [!] Fratrum Minorum Observantium provinciae nec non ejusdem Ordinis Monialium ac Tertii Ordinis confratrum sub titulo et protectione SS. Virginis Immaculatae titularis totius Ordinis et provinciae patronae dispositum pro anno Christi 1834 jussu et authoritate superiorum editum, Cracoviae [1833], [b.w.], Typis Academicis, $19 \mathrm{~cm} ., 49 \mathrm{ss}$.

Treść: jak w poz. 1.

[cz. 1a] Pia memoria partum ac fratrum nec non sororum nostri Ordinis S.P. Francisci ac benefactorum syndicorum conventuum, nec non ex stirpe fundatorum ab intermediis capitulis die 18 Octobris Radomiae celebrata anno Dni 1830 descripta et porrecta, s. 49.

Uwagi: zmiana tytułu kalendarza w stosunku do poz. 3; na str. tyt. pieczątka z napisem: „12 K Kalend L 1834", egzemplarz uszkodzony.

Oprawa: brak.

Sygn.: KUL V-8303/1834.

E. - , L. - , Z. -

5. [cz. 1] Directorium absolvendi divini officii necnon missarum celebrandarum juxta calendarium atque S.R.C. Decreta et rubricas Breviarii novissimas ordinatum ad usum Fratrum Minorum S.P. Francisci Observantium Provinciae Minoris Poloniae ac ejusdem Ordinis Monialium sub titulo Immaculatae Conceptionis B.M.V. in Annum Domini 1849 qui est annus comunis per p. Joannem Duclanum Tichy jussu superiorum editum, Varsaviae [1848], [b.w.], Ad Sanctam Crucem, 18 cm., 33 ss.

Treść: jak w poz. 1, Schematismus specialium diverse in Conventibus Ecclesiarum [...], Monita, Phases lunae, Tabula ortus [...].

[cz. 1a] Pia memoria partum ac fratrum nec non sororum nostri Ordinis S.P. Francisci ac benefactorum syndicorum conventuum, nec non ex stirpe fundatorum $\mathrm{ab}$ intermediis capitulis die 18 Octobris Radomiae celebrata anno Dni 1830 descripta et porrecta, s. 33 .

Proweniencja: „Applica pro Bibliotheca Conventus Cracoviensis, Fris Leopoldi Janikowski Praesbyteri'.

Uwagi: zmiana tytułu kalendarza w stosunku do poz. 4.

Oprawa: papier wydaw., miękka, napis: „Ordo 
divini officii Varsaviae 1849".

Sygn.: KUL V-8303/1849.

E. -, L. - , Z. -

\section{III.5. PROWINCJA GALICYJSKA (1810-1918)}

1. [cz. 1] Directorium absolvendi divini officii nec non missarum celebrandarum juxta calendarium atque S.R.C. Decreta et rubricas Breviarii novissimas ordinatum ad usum FF. Minorum S.P. Francisci Observantium per Galiciam Orientalem degentium sub titulo Immaculatae Conceptionis B.M.V. per prem. Laetum Mozler cum permissu superiorum pro anno communi MDCCCXXXIII [1833], Typis Premisliensibus 1833, [b.w.d.], 19 cm., 56 ss.

Treść: zasadniczy zrąb kalendarza.

[cz. 1a] Pia memoria, s. 45.

[cz. 2] Schematismus patrum ac fratrum Ordinis Franciscanorum vulgo Bernardinorum Provinciae Galicianae anno 1833, s. 46-56.

Treść: władze zwierzchnie prowincji, skład osobowy poszczególnych domów zakonnych, Prospectus.

Uwagi: na str. tyt. pieczątka z napisem: „12 K Kalend L 1833", egzemplarz uszkodzony.

Oprawa: papier wydaw., miękka, oryginalna, napis podobny jak na str. tyt., z tyłu napis: „Typis Premisliensibus 1833".

Sygn.: KUL V-8303/1833.

E.,- L. - , Z. -

2. [cz. 2] Schematismus patrum et fratrum Ordinis Minorum S.P. Francisci Regularis Observantiae vulgo Bernardinorum Provinciae Galicianae anno Christi MDCCCXLV [1845], [b.m. 1844], [b. w.d.], $19 \mathrm{~cm} .$, [18] ss.

Treść: Syndicus generalis, władze prowincjalne Zakonu, skład osobowy poszczególnych domów zakonnych, Invenitur in tota Galicia numerus.

Proweniencja: „Fr. Sojkowski [?] 1889”.

Uwagi: zmiana tytułu schematyzmu w stosunku do poz. 1.

Oprawa: papier, miękka., zniszczona.
Sygn.: KUL-V 8302/1845.

E. -, L. -, Z. -

3. [cz. 1] Directorium absolvendi divini officii nec non missarum celebrandarum juxta calendarium atq S.R.C. Decreta et rubricas Breviarii novissimas ordinatum ad usum FF. Minorum S.P. Francisci de Observantia Franciscanorum per Galiciam Orientalem degentium sub titulo Immaculatae Conceptionis B.M.V. per patrem Laetum Mozler permissu et authoritate A.R.P. Gabrielis Wincanty ministri provincialis pro anno communi 1847 editum, [b.m. 1846], [b.w.], Typis Petri Piller, 18 cm., [40] ss., [1] k.

Treść: jak w poz. 1.

[cz. 2] Schematismus [...] anno Christi 1847, c. d. s. [27-41].

Treść: jak w poz. 2.

Proweniencja: „A.R.P. Laurentio Wysoczyński".

Uwagi: zmiana tytułu kalendarza w stosunku do poz. 1; pieczątka z napisem: „3 K. kalend 1847”.

Oprawa: papier, miękka.

Sygn.: KUL-V 8303/1847.

E. -, L. - , Z. -

4. [cz. 2] Schematismus [...] anno Christi 1852, Vadoviciis [1851], [b.w.], Impresum in Typographia Joannae Pokorny, $18 \mathrm{~cm} ., 15 \mathrm{ss}$.

Treść: Syndicus generalis, Minister Generalis Ordinis, władze prowincjalne Zakonu, skład osobowy poszczególnych domów zakonnych, Invenitur in tota Galicia numerus, Defuncti.

Uwagi: ostatnia strona błędnie numerowana s. 57 zamiast 15 .

Oprawa: brak.

Sygn.: KUL-V 8302/1852.

E. -, L. - Z. -

5. [cz. 1] Directorium [...] pro anno communi 1853 editum, Vadoviciis [1852], [b. w.], Impressum in Typographia Joannae Pokorny viduae, $18 \mathrm{~cm}$., 54, [4] ss.

Treść: jak w poz. 1, Adnotatnio ritualis.

Uwagi: tytuł kalendarza, jak w poz. 3 ze zmianą 
- zamiast: „calendarium” jest „,calendarjum” [!], notatki ołówkiem, pieczątka okrągła, napis: „3 K K”.

Oprawa: papier wydaw., napis podobny jak na str. tyt., brak tylnej okładki.

Sygn.: KUL V-8303/1853.

E. cz. 1, t. I, s. 315 (w tym schematyzm), L. - Z. -

6. [cz. 2] Schematismus patrum et fratrum Ordinis Minorum S.P. Francisci Regularis Observantiae vulgo Bernardinorum Provinciae Galicianae sub titulo Immaculatae Conceptionis Bssmae Virg. Mariae anno Christi 1853, Vadoviciis [1852], [b. w.], Impresum in Typografia viduae Joannae Pokorny, $18 \mathrm{~cm} ., 16$ ss.

Treść: Syndicus generalis, Minister Generalis Ordinis, władze prowincjalne Zakonu, skład osobowy poszczególnych domów zakonnych, Invenitur in tota Galicia numerus, skład osobowy także domu zakonnego żeńskiego, Defuncti, Nota.

Uwagi: zmiana tytułu schematyzmu w stosunku do poz. 2.

Oprawa: brak oprawy z przodu, papier wydaw., miękka, napis z tyłu: „Vadoviciis Impr. in Typographia Joannae Pokorny".

Sygn.: KUL-V 8302/1853.

E. cz. 1, t. I, s. 315 (w tym kalendarz), L. -, Z.-

7. [cz. 1] Directorium absolvendi officii divini nec non missarum celebrandarum juxta calendarium atque S.R.C. Decreta et rubricas Breviarii novissimas ordinatum ad usum F.F. Minorum S.P.N. Francisci de Observantia Franciscanorum per Galiciam Orientalem degentium sub titulo Immaculatae Conceptionis Bssmae Virg. Mariae per patrem Laetum Mozler permissu et authoritate A.R.P. Gabrielis Wincanty ministri provincialis pro anno communi pro anno communi 1855 editum, Vadoviciis [1854], [b.w.], Typis Joannae Pokorny viduae, 18 cm., 52, 17 ss.

Treść: jak w poz. 1.

[cz. 2] [Schematyzm], 17 ss.

Treść: jak w poz. 6 .

Uwagi: zmiana tytułu kalendarza w stosunku do poz. 3, brak str. tyt. schematyzmu; na str. tyt. fragmenty pieczątek.
Oprawa: papier wydaw., miękka, napis podobny jak na str. tyt., napis z tyłu: „Vadoviciis Impr. in Typographia Joannae Pokorny".

Sygn.: KUL-V 8303/1855.

E. cz. 1, t. I, s. 315, L. -, Z. -

8. [cz. 2] Schematismus [...] anno Christi 1855, Wadoviciis [1854], [b.w.], Impressum in Typografia viduae Joannae Pokorny, $18 \mathrm{~cm} ., 17$ ss., [1] k.

Treść: jak w poz. 6 .

Oprawa: brak.

Sygn.: KUL-V 8302/1855.

E. cz. 1, t. IV, s. 190, L. -, Z. -

9. [cz. 1] Directorium absolvendi officii divini nec non missarum celebrandarum juxta calendarium atque S.R.C. Decreta et rubricas Breviarii novissimas ordinatum ad usum F.F. Minorum S.P.N. Francisci de Observantia Franciscanorum per Galiciam et Magnum Ducatum Cracoviensem degentium sub titulo Immaculatae Conceptionis Bssmae. Virg. Mariae permissu et auctoritate A.R.P. Laeti Mosler ministra provincialis per patrem Antonium Mikosz pro anno bisextili 1856 editum, Vadoviciis [1855], [b.w.], Typis Joannae Pokorny viduae, $18 \mathrm{~cm} ., 66$, [1] ss.

Treść: jak w poz. 1, Decretum.

[cz. 1a] Pia memoria [...], s. [66].

Uwagi: zmiana tytułu kalendarza w stosunku do poz. 7; stempel z opłatą i napisem: „3 kr. Kalender Stempel”, pieczątka.

Oprawa: brak.

Sygn.: KUL-V 8302/1855.

E. cz. 1, t. IV, s.190, L. -, Z. -

10. Directorium absolvendi officii divini nec non missarum celebrandarum juxta calendarium atque S.R.C. Decreta et rubricas Breviarii novissimas ordinatum ad usum F.F. Minorum S.P.N. Francisci de Observantia Franciscanorum vulgo Bernardinorum, per Galiciam Orientalem degentium sub titulo Immaculatae Conceptionis B.V.Mariae pro anno communi $\mathbf{1 8 5 8}$, Leopoli [1858], [b.w.], Typis Michaelis F. 
Poremba, $20 \mathrm{~cm}$., [30] ss.

Treść: zasadniczy zrąb kalendarza, Decreta.

Uwagi: zmiana tytułu kalendarza w stosunku do poz. 9; uzupełnienie adresu wydawniczego z okładki.

Oprawa: papier wydaw., napis podobny jak na str. tyt.

Sygn.: KUL V-8303/1858.

E. cz. 1, t. IV, s.315, L. -, Z. -

11. [cz. 1] Directorium [...] pro anno communi 1859, Leopoli [1858] [b.w.], Typis Michaelis F. Poremba, $21 \mathrm{~cm}$., [36] ss.

Treść: jak w poz. 1.

Oprawa: jak w poz. 10.

Sygn.: KUL V-8303/1859.

E. cz. 1, t. IV, s.315, L. -, Z. -

12. [cz. 2] Schematismus [...] annum Christi 1861, Leopoli [1860], [b.w.], Typis Michaelis F. Poremba, $20 \mathrm{~cm}$., $30 \mathrm{ss}$.

Treść: Syndicus generalis, Minister generalis Ordinis, władze prowincjalne Zakonu, skład osobowy poszczególnych domów zakonnych, Invenitur in tota Galicia numerus, skład osobowy także domu zakonnego żeńskiego, Defuncti, pontyfikat aktualnego papieża, historia prowincji.

Oprawa: brak.

Sygn.: KUL-V 8302/1861.

E. cz. 1, t. IV, s. 190, L. - Z. -

13. [cz. 2] Schematismus patrum et fratrum Ordinis Minorum S.P. Francisci Regularis Observantiae vulgo Bernardinorum Provinciae Galicianae sub titulo Immaculatae Conceptionis Beatissimae Virginis Mariae ad annum Christi 1863, Leopoli 1863 [b.w.], Typis Michaelis F. Poremba, $20 \mathrm{~cm} ., 32 \mathrm{ss}$.

Treść: podobnie jak w poz. 12.

Uwagi: zmiana tytułu schematyzmu w stosunku do poz. 6 .

Oprawa: brak.

Sygn.: KUL-V 8302/1863.

E. - , L. - , Z. -

14. [cz. 2] Schematismus [...] ad annum Christi 1864, Leopoli 1864 [b.w.], Ty- pis Michaelis F. Poremba, 20 cm., 32 ss.

Treść: jak w poz. 6 .

Oprawa: brak.

Sygn.: KUL-V 8302/1864.

E. cz. 1, t. IV, s. 190, L. -, Z. -

15. [cz. 1] Directorium [...] pro anno 1870, Leopoli 1869, [b.w.], Typis Michaelis F. Poremba, 21 cm., [40] ss., egz. interfol. [19] kk.

Treść: jak w poz. 1.

Proweniencja: R.P. Modesti Scieszka [Ścieszko] [?] Custodis Cntus [?] [.....], Pieczęć owalna z napisem: „Biblioteka O.O. Bernardynów w Krakowie”.

Uwagi: liczne notatki (intencje mszalne).

Oprawa: tektura, twarda, tłoczone zdobienia złocone, napis jak w proweniencji, brak tylnej okładki.

Sygn.: KUL V-8303/1870.

E. - , L. -, Z. -

16. [cz. 1] Directorium [...] pro Anno Domini 1873, Leopoli 1872, [b.w.], Typis Michaelis F. Poremba, $21 \mathrm{~cm}$., [40] ss.

Treść: jak w poz. 1, Lunationes, Lectio IX.

Oprawa: papier wydaw., napis podobny jak na str. tyt., z tyłu adres wydawniczy.

Sygn.: KUL V-8303/1873.

E. - , L. - , Z. -

17. [cz. 2] Schematismus [...] ad annum Christi 1873, Leopoli 1872, [b.w.], Typis Michaelis F. Poremba, 29 ss., s. [3032].

Treść: podobnie jak w poz. 12.

Oprawa: jak w poz. 16.

Sygn.: KUL-V 8302/1873.

E. -, L. -, Z. poz. 729 .

18. [cz. 2] Schematismus [...] ad annum Christi 1874, Leopoli 1874, [b.w.], Typis „Przegląd Lwowski” \& „Chata”, 22, [3] ss.

Treść: podobnie jak w poz. 12.

Oprawa: jak w poz. 10.

Sygn.: KUL-V 8302/1874.

E. -, L. -, Z. poz. 729 . 
19. [cz. 2] Schematismus [...] ad annum Christi 1876, [b.m. 1875], [b.w.d.], 20 cm., 34 ss.

Treść: podobnie jak w poz. 12, Examinatores provinciales, Series [...] Patrum ministrorum provincialium $[\ldots]$, Summarius elenchus religiosorum provinciae $[\ldots]$.

Uwagi: pojedyncze notatki.

Oprawa: brak.

Sygn.: KUL-V 8302/1876.

E. -, L. -, Z. poz. 729 .

20. [cz. 1] Directorium absolvendi officii divini nec non missarum celebrandarum juxta calendarium atque S.R.C. Decreta et rubricas Breviarii novissimas ordinatum ad usum F.F. Minorum S.P.N. Francisci de Observantia Franciscanorum vulgo Bernardinorum, per Galiciam Orientalem nec non Occidentalem et Magnum Ducatum Cracoviensem degentium sub titulo Immaculatae Conceptionis B.V.Mariae pro Anno Domini 1880, Leopoli 1879, [b.w.], Typis A Waydowicz (ant. M. F. Poremba) sub directione Fel. Bednarski, 21 cm., 42 ss., [1] $\mathrm{k}$.

Treść: jak w poz. 10.

Uwagi: zmiana tytułu kalendarza w stosunku do poz. 10 , notatki w treści kalendarza.

Oprawa: jak w poz. 11, brak tylnej okładki.

Sygn.: KUL V-8303/1880.

E. - , L.,- Z. -

21. [cz. 2] Schematismus patrum et fratrum Ordinis Minorum S.P. Francisci Regularis Observantiae vulgo Bernardinorum Provinciae Galicianae sub titulo Immaculatae Conceptionis B.V.Mariae ad annum Christi 1880, Leopoli 1879, [b.w.], Typis A. Waydowicz (ant. M. F. Poremba), sub directione Fel. Bednarski, 21 cm., 34, [1] ss.

Treść: jak w poz. 12.

Uwagi: zmiana tytułu schematyzmu w stosunku do poz. 13.

Oprawa: jak w poz. 10.

Sygn.: KUL-V 8302/1880.

E. - , L. - , Z. -
22. [cz. 2] Schematismus [...] ad annum Christi 1881, Leopoli 1880, [b.w.], Typis A. Waydowicz (ant. M. F. Poremba), sub directione Fel. Bednarski, $21 \mathrm{~cm}$., 34, [1] ss.

Treść: jak w poz. 12.

Proweniencja: na s. 2 pieczęć o treści: "Bibl. Jag. 1966 Cz. D. 329”, na s. 3 pieczęć Bibl. UJ.

Oprawa: jak w poz. 10.

Sygn.: KUL-V 8302/1881.

E. -, L. -, Z. -

23. [cz. 2] Schematismus [...] ad annum Christi 1882, Leopoli 1882, [b.w.], Typis A. Wajdowicz (ant. M. F. Poremba), sub directione Fel. Bednarski, $21 \mathrm{~cm}$., 45 ss., [1] k.

Treść: Syndicus generalis, Minister generalis Ordinis, władze prowincjalne zakonu, skład osobowy poszczególnych domów zakonnych, Invenitur in tota Galicia numerus, skład osobowy także domu zakonnego żeńskiego, Defuncti, pontyfikat aktualnego papieża, historia prowincji. Appendix tertiarii, Igitur Provincia haec, Elenchus religiosorum [...] Provinciae, Nomina sacerdotum et FF. clericorum [...] in ordinem.

Oprawa: jak w poz. 10.

Sygn.: KUL-V 8302/1882.

E. - , L. - , Z. -

24. [cz. 2] Schematismus [...] ad annum Christi 1883, Leopoli, [b.w.], Typis A. Wajdowicz (ant. M. F. Poremba), sub directione Fel. Bednarski, $22 \mathrm{~cm}$., 40 ss.

Treść: jak w poz. 12, Igitur Provincia haec, Elenchus religiosorum [...] Provinciae, Ab edit. praeced. schematismi e vivis recesserunt, Alfabeticus index personarum [...].

Oprawa: jak w poz. 10.

Sygn.: KUL-V 8302/1883.

E. - , L. - , Z. -

25. [cz. 2] Schematismus [...] ad annum Christi 1886, Cracoviae 1886, sumptibus PP. Bernardinorum. E Typographia Ephemeridum „Czas” Fr. Kluczycki \& Soc., provisore Josepho Łakociński, 18 cm., 36 ss. 
Treść: jak w poz. 12, Igitur Provincia haec, Elenchus religiosorum [...] Provinciae.

Oprawa: jak w poz. 10.

Sygn.: KUL-V 8302/1886.

E. -, L. -, Z. poz. 729 .

26. [cz. 1] Ordo divini officii sacrique celebrandi in Provincia FF. Minorum de Observantia vulgo Bernardinorum per Galiciam et M. D. Cracoviensem degentium ex mandato Adm. rev. p. Lucae Dankiewicz ministri provincialis dispositus pro Anno Domini 1887, Cracoviae 1887, sumptibus PP. Bernardinorum, E Typographia Ephemeridum „Czas” Fr. Kluczycki \& Soc., provisore Josepho Łakociński, $18 \mathrm{~cm} ., 57$ ss., [3] kk.

Treść: Calendarium religiosum, Decretum, Nota, zasadniczy zrąb kalendarza, Mutatniones durante typo Schematismi, Tabulao rtus et occasus solis, Lunationes astronomicae [...].

Uwagi: zmiana tytułu kalendarza w stosunku do poz. 20.

Oprawa: jak w poz. 10.

Sygn.: KUL-V 8302/1886.

E. -, L. - , Z. -

27. [cz. 2] Schematismus [...] ad annum Christi 1888, Cracoviae 1888, sumptibus PP. Bernardinorum, E Typographia Ephemeridum „Czas” Fr. Kluczycki \& Soc., provisore Josepho Łakociński, 18 cm., 38 ss., [1] k.

Treść: jak w poz. 23.

Oprawa: jak w poz.10.

Sygn.: KUL-V 8302/1888.

E. cz. 4, t. IV, s.123, L. -, Z. -

28. [cz. 2] Schematismus [...] ad annum Christi 1889, Cracoviae 1889, sumptibus PP. Bernardinorum, E Typographia Ephemeridum „Czas” Fr. Kluczycki \& Soc., provisore Josepho Łakociński, 18 cm., 37, [2] ss.

Treść: jak w poz. 12.

Oprawa: jak w poz.11.

Sygn.: KUL-V 8302/1889.

E. cz. 4 , t. IV, s.123, L. - Z. -
29. [cz. 2] Schematismus [...] ad annum Christi 1890, Cracoviae 1890, sumptibus PP. Bernardinorum, E Typographia Ephemeridum „Czas” Fr. Kluczycki \& Soc., provisore Josepho Łakociński, 18 cm., 41 ss., [3] kk.

Treść: jak w poz. 23, Index alphabeticus conventuum, Index alphabeticus personarum.

Oprawa: jak w poz. 11.

Sygn.: KUL-V 8302/1890.

E. cz. 4, t. IV, s.123, L. -, Z. -

30. [cz. 2] Schematismus [...] ad annum Christi 1892, Cracoviae 1891, E Typographia L. Anczyc et Sociorum., provisore Joanne Gadowski, sumptibus PP. Bernardinorum, $18 \mathrm{~cm}$., $44 \mathrm{ss}$.

Treść: podobnie jak w poz. 23, Conceptus generalis religiosorum et Conventuum, Index alphabeticus personarum.

Oprawa: jak w poz. 11.

Sygn.: KUL-V 8302/1892.

E. -, L. -, Z. poz. 729 .

31. [cz. 2] Schematismus [...] ad annum Christi 1895, Leopoli 1894, sumptibus PP. Bernardinorum, [Typis E. Winiarz], $19 \mathrm{~cm} ., 48 \mathrm{ss}$.

Treść: jak w poz. 24, Conceptus numericus individuorum Provinciae.

Oprawa: półmateriał, twarda, złocona data: „1895”.

Sygn.: KUL-V 8302/1895.

E. cz. 4, t. IV, s. 123, L. -, Z. -

32. [cz. 2] Historia et catalogus observantis Provinciae Ordinis Minorum S. P.N. Francisci vulgo Bernardinorum olim Provinciae Russiae modo Galicianae vocitatae sub titulo Immaculatae Conceptionis B.V. Mariae ad annum 1896, Leopoli 1895, Summptibus Provinciae PP. Bernardinorum, Typis Eduardi Winiarz, 19 cm., 71 ss.

Treść: jak w poz. 30, Series extraneorum vicariorum (1453-1466), Series vicariorum provincialium ex proporia natione (1467-1515), Ministri provinciales (1517-1627), Ministri provinciales Provinciae Russiae (1627-1634), Iterata erectio Provinciae Rus- 
siae (1637-1894), Catalogus locorum ubi conventus fratrum olim per integram Poloniam existebaut, Pro notitia, Conceptus numericus individuorum Provinciae.

Uwagi: zmiana tytułu schematyzmu w stosunku do poz. 21.

Oprawa: papier, miękka - pierwotna, tektura, twarda - wtórna.

Sygn.: KUL-V 8302/1896.

E. -, L. -, Z. poz. 729 .

33. [cz. 2] Historia et catalogus [...] ad annum 1897, Leopoli 1896, sumptibus Provinciae PP. Bernardinorum, [Z Drukarni Zakładu Narod. imienia Ossolińskich pod zarządem Juliusza Birkenmaiera], 17 cm., 75 ss., [1] k.

Treść: jak w poz. 32, Series Superiorissarum (1645-1896).

Uwagi: na stronie nlb. napis: „Z drukarni Zakładu Narod. imienia Ossolińskich pod zarządem Juliusza Birkenmaiera".

Oprawa: półmateriał, twarda, tłoczona, złocony napis: „1897’, złocone brzegi.

Sygn.: KUL-V 8302/1897.

E. cz. 4, t. II, s.123, L. -, Z. poz. 729 .

34. [cz. 2] Historia et catalogus Ordinis Minorum S.P.N. Francisci vulgo Bernardinorum olim Provinciae Russiae modo Galicianae vocitatae sub titulo Immaculatae Conceptionis B.V. Mariae ad annum 1898, Leopoli 1897, sumptibus Provinciae PP. Bernardinorum, Impressum in Typographia Catholica J. Chęciński, 19 cm., 65 SS.

Treść: władze zakonu, syndyk, Historia brevis, Historia provicniae Russie [...], skład osobowy poszczególnych domów zakonnych (z obszerna historią), Elapso anno obiere in Domino, Igitur provincia haec, Index alphabeticus patrum et fraturm [...], Index conventuum.

Uwagi: zmiana tytułu schematyzmu w stosunku do poz. 32; brak s. 13-16.

Oprawa: papier wydaw., miękka, tłoczona, napis jak na str. tyt.

Sygn.: KUL-V 8302/1898.

E. -, L. -, Z. poz. 729 .
35. [cz. 2] Schematismus Ordinis Fratrum Minorum S.P.N. Francisci almae Provinciae B.V. Mariae Immaculatae Conceptionis in Galicia pro Anno Domini 1900, Cracoviae 1900, [sumptibus Fratrum Minorum], E Typographia „Czas”, excudebat J. Łakociński, 18 cm., 103 ss.

Treść: jak w poz. 24, Conceptus generalis religiosorum $[\ldots]$.

Uwagi: zmiana tytułu schematyzmu w stosunku do poz. 34; wydawca $\mathrm{z}$ treści schematyzmu.

Oprawa: jak w poz. 11.

Sygn.: KUL-V 8302/1900.

E. -, L. s. 393, Z. poz. 729.

36. [cz. 2] Schematismus [...] pro Anno Domini 1901, Cracoviae 1900, [sumptibus Fratrum Minorum], E Typographia Catholica J. Chęciński, 18 cm., 102, [1] ss.

Treść: jak w poz. 24, Mutatniones durante typo factae, Index.

Uwagi: prywatne notatki na okładce.

Oprawa: jak w poz. 11.

Sygn.: KUL-V 8302/1901.

E. cz. 4, t. IV, s.123, L. -, Z. poz. 729.

37. [cz. 2] Schematismus Ordinis Fratrum Minorum S.P.N. Francisci almae Provinciae B.V. Mariae Immaculatae Conceptionis in Galicia iussu A.R.P. min. provincialis ad normam CC. Gen. rite compositus pro Anno Domini 1902, Cracoviae 1902, [sumptibus Fratrum Minorum], E Typographia „Czas”, 18 cm., 97, [1] ss.

Treśé: jak w poz. 35, Origo Ordinis Fratrum Minorum in Polonia.

Uwagi: zmiana tytułu schematyzmu w stosunku do poz. 35.

Oprawa: jak w poz. 11.

Sygn.: KUL-V 8302/1902.

E. - , L. - , Z. -

38. [cz. 2] Schematismus [...] pro Anno Domini 1903, Stryj 1902, sumptibus Fratrum Minorum, E Typographia A. Olbrich, $18 \mathrm{~cm} ., 115 \mathrm{ss}$.

Treść: jak w poz. 36.

Uwagi: prywatne rachunki. 
Oprawa: jak w poz. 11.

Sygn.: KUL-V 8302/1903.

E. -, L. s. 393, Z. poz. 729.

39. [cz. 2] Schematismus [...] pro Anno Domini 1905, Stryj 1904, sumptibus Fratrum Minorum, E Typographia A. Olbrich, $19 \mathrm{~cm} ., 100 \mathrm{ss}$.

Treść: podobnie jak w poz. 36, Examinatores pro praedicatoribus et confessiariis neomystis.

Oprawa: tworzywo sztuczne, twarda, zdobiona, tłoczony rok: „1905”.

Sygn.: KUL-V 8302/1905.

E. - , L. - , Z. -

40. [cz. 2] [Schematyzm na rok 1906], [b.m. 1905], [b.w.d.], 94, [1] ss.

Treść: jak w poz. 36.

Uwagi: brak pierwszych 17 stron i stron końcowych.

Oprawa: brak.

Sygn.: KUL-V 8302/1906.

E.,- L.,- Z. -

41. [cz. 2] Schematismus [...] pro Anno Domini 1907, Stryj 1906, [sumptibus Fratrum Minorum], E Typographia A. Olbrich, $18 \mathrm{~cm} ., 101 \mathrm{ss}$.

Treść: podobnie jak w poz. 36 .

Oprawa: papier wydaw., napis jak na str. tyt.

Sygn.: KUL-V 8302/1907.

E. -, L. -, Z. -

42. [cz. 2] Schematismus [...] pro Anno Domini 1908, Stryj 1907, sumptibus Fratrum Minorum, E Typographia A. Olbrich, $18 \mathrm{~cm} ., 112 \mathrm{ss}$.

Treść: podobnie jak w poz. 36, indeks nazwisk, indeks imion.

Oprawa: jak w poz. 11.

Sygn.: KUL-V 8302/1908.

E. -, L. S. 393-394, Z. -

43. [cz. 2] Schematismus Ordinis Fratrum Minorum S.P.N. Francisci almae Provinciae B.V.Mariae Immaculatae Conceptionis in Galicia auctoritate A.R.P. ministri provincialis ad normam CC. Gen. rite com- positus pro Anno Domini 1909, Stryj 1908, sumptibus Fratrum Minorum, E Typographia A. Olbrich, $18 \mathrm{~cm} ., 112 \mathrm{ss}$.

Treść: jak w poz. 36.

Uwagi: zmiana tytułu schematyzmu w stosunku do poz. 37

Oprawa: jak w poz. 11.

Sygn.: KUL-V 8302/1909.

E. -, L. s. 394, Z. -

44. [cz. 1] Ordo divini officii recitandi sacrique peragendi ad usum Fratrum Minorum et Monialium Provinciae Immaculatae Conceptionis B.V. Mariae per Galiciam et M. D. Cracoviensem degentium auctoritate Adm. Rndi. patris Danielis Magoński, Ministri prlis dispositus pro anno communi 1910, Stryj 1909, sumptibus Fratrum Minorum, E Typographia A. Olbrich, $19 \mathrm{~cm}$., $62,[1]$ ss.

Treść: jak w poz. 1, Appendix.

Uwagi: zmiana tytułu kalendarza w stosunku do poz. 20.

Oprawa: jak w poz. 11.

Sygn.: KUL V-8303/1910.

E. - , L. - , Z. -

45. [cz. 2] Schematismus [...] pro Anno Domini 1911, Stryj 1910, sumptibus Fratrum Minorum, E Typographia A. Olbrich, $19 \mathrm{~cm} ., 112 \mathrm{ss}$.

Treść: jak w poz. 36, Consilium vigilantiae.

Uwagi: tytuł schematyzmu, jak w poz. 44 ze zmianą - ,,[...] ad normam Const. Gen. rite compositus".

Oprawa: jak w poz. 11.

Sygn.: KUL-V 8302/1911.

E. -, L. s. 394, Z. -

46. [cz. 2] Schematismus Ordinis Fratrum Minorum S.P.N. Francisci almae Provinciae B.V.Mariae Immaculatae Conceptionis in Galicia (vulgo PP. Bernardinorum) auctoritate A.R.P. ministri provincialis ad normam CC. Gen. rite compositus pro Anno Domini 1912, Stryj 1911, sumptibus Fratrum Minorum, E Typographia A. Olbrich, $19 \mathrm{~cm} ., 77$, [2] ss. 
Treść: jak w poz. 46, Index alpfabeticus personarum, Themata elaboranda pro anno [...].

Uwagi: zmiana tytułu schematyzmu w stosunku do poz. 36.

Oprawa: jak w poz. 11.

Sygn.: KUL-V 8302/1912.

E. - , L. - , Z. -

47. [cz. 1] Kalendarium Ordinis Fratrum Minorum Provinciae Immaculatae Conceptionis. B.V. Mariae in Galicia pro anno communi 1913, (oprac. p. Henrico Ragan), Stryj 1912, E Typographia A. Olbrich, 64 ss.

Treść: jak w poz. 44.

Uwagi: zmiana tytułu kalendarza w stosunku do poz. 44.

Oprawa: brak.

Sygn.: KUL-V 8303/1913.

E. - , L. - , Z. -

48. [cz. 2] Schematismus [...] pro Anno Domini 1913, Stryj 1912, sumptibus Fratrum Minorum, E Typographia A. Olbrich, $19 \mathrm{~cm} ., 76$, [2] ss., [1] k.

Treść: jak w poz. 46.

Oprawa: jak w poz. 11.

Sygn.: KUL-V 8302/1913.

E. - , L. - , Z. -

49. [cz. 2] Schematismus [...] pro Anno Domini 1914, Stryj 1914, sumptibus Fratrum Minorum, E Typographia A. Olbrich, $20 \mathrm{~cm} ., 71$, [3] ss. lium.

Treść: jak w poz. 46, Index alpfabeticus monia-

Uwagi: drugi ze schematyzmów z tego roku zawiera taką samą treść, jednak oprawiony jest w okładkę miękką $(20 \mathrm{~cm})$. Może to świadczyć, iż powstawały 2 wersje schematyzmów. Ewentualnie można było zamówić oprawę introligatorską.

Oprawa: półmateriał, twarda, tłoczony ozdobny wzór i złocony napis: ,Schematismus (Fratrum Minorum-bez złoceń) 1914”, z tyłu napis: „A. Olbrich, Drukarnia i Introligatornia w Stryju".

Sygn.: KUL-V 8302/1914.

E. -, L. -, Z. -
50. [cz. 1] Kalendarium Romano-Seraphicum Provinciae Immaculatae Conceptionis B.V.Mariae in Galicia pro anno Comuni 1915, Cracoviae 1915, Typogr. W. L. Anczyc \& Soc., 19 cm., 68 ss.

Treść: jak w poz. 44.

Uwagi: zmiana tytułu kalendarza w stosunku do poz. 47.

Oprawa: jak w poz. 11.

Sygn.: KUL V-8303/1915.

E. - , L. - , Z. -

51. [cz. 2] Schematismus [...] pro Anno Domini 1915, 1916, 1917, Leopoli 1917, sumptibus Fratrum Minorum E Typographia Felicis Bednarski, 16 cm., 36, [7] ss.

Treść: jak w poz. 46, Patres ac fratres in bello occupati, Fratres conversi militiae applicati.

Proweniencja: pieczęć owalna na str. tyt., napis: „Bibljoteka Klasztoru O.O Bernardynów we Lwowie"; przedstawienie św. Franciszka. Taka sama pięczeć na ostatniej stronie.

Oprawa: jak w poz. 11.

Sygn.: KUL-V 8302/1915-17.

E. -, L. -, Z. -

\section{III.6. PROWINCJA POLSKA (1918-)}

1. [cz. 2] Schematismus Ordinis Fratrum Minorum S.P.N. Francisci almae Provinciae B.V.Mariae Immaculatae Conceptionis in Polonia (vulgo PP. Bernardinorum) auctoritate A.R.P. ministri provincialis ad normam Const. Gen. rite compositus pro Anno Domini 1922, Leopoli 1922, sumptibus Fratrum Minorum, E Typographia „Akademicka”, 16 cm., 39, [9] ss.

Treść: władze zakonu, skład osobowy domów zakonnych (w tym żeńskich), Pie in Domino obierunt, Index.

Oprawa: oryginalna - papier wydaw., miękka; wtórna - twarda, tektura.

Sygn.: KUL V-8302/1922.

E. -, L. -, Z. poz. 729.

2. Sygn.: KUL V-8302/1923 - brak. 
3. [cz. 2] Brevis historia et catalogus Ord. FF. Min. S.P.N. Francisci almae Provinciae Immaculatae Conceptionis B.V. Mariae in Polonia (vulgo PP. Bernardinorum) auctoritate A.R.P. ministri provincialis ad normam Const. Gener. rite concinnavit P. Ceslaus Bogdalski pro Anno Domini 1924, Cracoviae 1924, sumptibus Fratrum Minorum, Typis Ephemeridis „Czas”, provisore Leopoldo Wójcik, 23 cm., 64 ss.

Treść: jak w poz. 1, władze zakonu, historia poszczególnych domów zakonnych, Pie in Domino Obierunt [1922-1924], Conspectus generalis [...].

Uwagi: zmiana tytułu schematyzmu w stosunku do poz. 1.

Oprawa: jak w poz. 1.

Sygn.: KUL V-8302/1924.

E. -, L. s. 394, Z. poz. 729.

4. [cz. 2] Schematismus Ord. FF. Minorum S.P.N. Francisci almae Provinciae Immaculatae Conceptionis B.V. Mariae in Polonia (vulgo PP. Bernardinorum) auctoritate A.R.P. ministri provincialis ad normam Const. Gen. rite compositus pro Anno Domini 1927, Leopoli 1927, sumptibus Provinciae, [Pierwsza Związkowa Drukarnia], $21 \mathrm{~cm} ., 75 \mathrm{ss}$.

Treść: jak w poz. 3, Beati et martyres Poloni ex [...] Bernardinorum [...], Pie in Domino obierunt [1924-1927], Index.

Uwagi: zmiana tytułu schematyzmu w stosunku do poz. 2.

Oprawa: papier wydaw., miękka.

Sygn.: KUL V-8302/1927.

E. -, L. s. 394, Z. poz. 729 .

5. Sygn.: KUL V-8302/1929 - brak.

6. [cz. 2] Schematismus [...] pro Anno Domini 1932, Leopoli 1931, sumptibus Provinciae, [b. d.], 17 cm., 64 ss.

Treść: jak w poz. 3, bez historii domów zakonnych, Pie in Domino obierunt [1927-1931], Materia examinis.

Oprawa: jak w poz. 1.

Sygn.: KUL V-8302/1932.

E. -, L. -, Z. poz. 729 .
7. [cz. 2] Schematismus [...] pro Anno Domini 1933, Leopoli 1932, sumptibus Provinciae, Ex Typographia „Pierwsza Związkowa", 17 cm., 64 ss.

Treść: jak w poz. 6 .

Oprawa: jak w poz. 1.

Sygn.: KUL V-8302/1933.

E. - L. - , Z. -

8. [cz. 2] Schematismus [...] pro Anno Domini 1934, Ressoviae 1933, sumptibus Provinciae, Ex Typographia J. A. Pelar i Spółka, 16 cm., 88 ss.

Treść: jak w poz. 3, fotografie przełożonych.

Uwagi: zmiana tytułu kalendarza w stosunku do poz. 1: „Schematismus [...] ad normam Constitut. Gener. Rite compositus".

Oprawa: oryginalna - papier; miękka; wtórna twarda, tektura.

Sygn.: KUL V-8302/1934.

E. -, L. -, Z. poz. 729 .

9. [cz. 2] Schematismus [...] pro Anno Domini 1935, Ressoviae 1934, sumptibus Provinciae, ExTypographiaJ.A.PelariSpółka, 17 cm., 90 ss.

Treść: jak w poz. 6.

Oprawa: jak w poz. 1.

Sygn.: KUL V-8302/1935.

E. - , L. - , Z. -

10. [cz. 2] Schematismus [...] pro Anno Domini 1936, Ressoviae, sumptibus Provinciae, ExTypographiaJ.A.PelariSpółka, 17 cm., 92 ss.

Treść: jak w poz. 6.

Oprawa: jak w poz. 4.

Uwagi: na okładce napis atramentem: „fr. Marcius".

Sygn.: KUL V-8302/1936.

E. -, L. s. 394 , Z. -

11. [cz. 2] Schematismus [...] pro Anno Domini 1938, Leopold [1937], sumptibus Provinciae, Pierwsza Związkowa Drukarnia, 23 cm., 104 ss.

Treść: jak w poz. 6, Pie in Domino obierunt [1936-1938]. 
Oprawa: jak w poz. 4.

Sygn.: KUL V-8302/1938.

E. -, L. s. 394 , Z. -

12. [cz. 1] Appendix ad kalendarium romano-seraphicum ad usum Provinciae Immac. Conc. B.M.V. in Polonia pro anno 1939, Radecznicae [1938], [b.w.], Typis Proviniciae O. Fr. M. Im. Conc. in Polonia impressum, $17 \mathrm{~cm} ., 33 \mathrm{ss}$.

Treść: zasadniczy zrąb kalenadarza.

Oprawa: papier wydaw., napis jak na str. tyt.

Sygn.: KUL V-8303/19139.

E. - , L.,- Z. -

13. [cz. 2] Schematismus [...] pro Anno Domini 1939, Radecznicae [1938], sumptibus Provinciae, Typis Provinciae O. Fr. M. Im. Conc. in Polonia impressum, 23 cm., 127 ss.

Treść: jak w poz. 6.

Uwagi: w indeksie wykreślono niektóre nazwiska.

Oprawa: jak w poz. 1.

Sygn.: KUL V-8302/1939.

E. -, L. -, Z. poz. 729.

14. [cz. 1] Kalendarium Ordinis Fratrum Minorum pro Anno Domini 1945, [b.m. 1944], [b.w.], Typis Officianae Polonicae Fr. Zemanek, 17 cm., 57 ss., [1] k.wyrwana.

Treść: jak w poz. 12.

Uwagi: zmiana tytułu kalendarza w stosunku do poz. 12; notatki atramentem, do tego egzemplarza dołączono: Ordo divini officii pro anno salutis 1944 ad usum Ordinis Fratrum Minorum, [b.m. 1943], [b. w.d.], $15 \mathrm{~cm}$., 8 ss. - brak wszystkich stron.

Oprawa: jak w poz. 12.

Sygn.: KUL V-8303/19145.

E. - , L. - , Z. -

15. [cz. 1] Kalendarium ad usum Ordinis Fratrum Minorum in Polonia pro Anno Domini 1946, Cracoviae 1945, [b.w.], Typis Offic. Typ. „Drukarnia Przemysłowa" Caroli Podgórczyk, 17 cm., 87 ss.

Treść: uwagi, jak w poz. 12.
Uwagi: zmiana tytułu kalendarza w stosunku do poz. 14; jęz. łac., jęz. pol.

Oprawa: jak w poz. 12.

Sygn.: KUL V-8303/1946.

E. -, L. - , Z. -

16. [cz. 1] Kalendarium [...] pro Anno Domini 1947, Cracoviae 1946, sumptibus Provincialatus PP. Bernardinorum, Drukarnia Związkowa, 17 cm., 91 ss.

Treść: jak w poz. 15.

Uwagi: jak w poz. 15.

Oprawa: jak w poz. 12.

Sygn.: KUL V-8303/1947.

E. -, L. - Z. -

17. [cz. 1] Kalendarium [...] pro Anno Domini 1948, Cracoviae 1947, sumptibus Ordinis Fratrum Minorum, Drukarnia Związkowa, 17 cm., 82 ss., [1] k.

Treść: jak w poz. 15.

Uwagi: jak w poz. 15.

Oprawa: jak w poz. 12.

Sygn.: KUL V-8303/1947.

E. - , L. - , Z. -

18. [cz. 1] Kalendarium [...] pro Anno Domini 1949, Cracoviae 1948, sumptibus Ordinis Fratrum Minorum, Drukarnia Związkowa, $18 \mathrm{~cm} ., 92$ ss.

Treść: jak w poz. 15.

Proweniencja: „O. Józef”.

Uwagi: jak w poz. 15.

Oprawa: jak w poz. 12.

Sygn.: KUL V-8303/1949.

E. - , L. - , Z. -

19. [cz. 1] Kalendarium [...] pro Anno Domini 1950, Cracoviae 1949, sumptibus Ordinis Fratrum Minorum, Drukarnia Związkowa, 17 cm., 98 ss.

Treść: jak w poz. 15, Indicator.

Uwagi: jak w poz. 15.

Oprawa: jak w poz. 12.

Sygn.: KUL V-8303/1950.

E. - , L. - , Z. - 
20. [cz. 1] Kalendarium [...] pro Anno Domini 1951, Cracoviae 1950, sumptibus Ordinis Fratrum Minorum, Drukarnia Związkowa, $18 \mathrm{~cm} ., 100 \mathrm{ss}$.

Treść: jak w poz. 19.

Proweniencja: „O. Józef”.

Uwagi: jak w poz. 15.

Oprawa: jak w poz. 12.

Sygn.: KUL V-8303/1949.

E. - L. - , Z. -

21. [cz. 2] Elenchus Ordinis Fratrum Minorum Provinciae Immaculatae Conceptionis BMV. (PP. Bernardinorum) in Polonia auctoritate A.R.P. ministri provincialis ad normam Constitut. Gener. rite compositus pro Anno Domini 1958, composuit $\mathrm{p}$. Hieronymus Wyczawski, Cracoviae 1958, Wyd. Św. Krzyża w Opolu, Drukarnia Związkowa, 20 cm., 80 ss.

Treść: władze zakonu, skład osobowy domów zakonnych (w tym żeńskiego), Fratres in Domino mortui [1939-1957], Conspectus generalis Provinciae, Statistica $[\ldots]$, Index.

Uwagi: zmiana tytułu schematyzmu w stosunku do poz. 4.

Oprawa: jak w poz. 12.

Sygn.: KUL V-8302/1958.

E. -, L. s. 394, Z. -

22. Sygn.: KUL V-8302/1959 - brak.

23. [cz. 2] Schematismus almae Ordinis Fratrum Minorum Provinciae Immaculatae Conceptionis B.M.V. in Polonia (PP. Bernardinorum) auctoritate A.R.P. Willhelmi Wrona Ministri provincialis pro Anno Domini 1965 editus, Asisii 1965, Typ. Portiunculae, $23 \mathrm{~cm}$., 102 ss.

Treść: władze zakonu, skład osobowy domów zakonnych (w tym żeńskiego), Pater ac fratres vita functi [1958-1965], Conspectus generalis Provinciae [...], Index.

Uwagi: zmiana tytułu schematyzmu w stosunku do poz. 21.

Oprawa: oryginalna - papier; miękka.

Sygn.: KUL V-8302/1965.

E. - , L. - , Z. -
24. Schematyzm Prowincji Niepokalanego Poczęcia NMP O.O. Bernardynów Zakonu Braci Mniejszych w Polsce [1997], Kraków 1997, Kuria Prowincjonalna O.O. Bernardynów, Wyd. ITKM, 21 cm., 292 ss.

Treść: władze zakonu, skład osobowy domów zakonnych, adresy, szczegółowe dane.

Uwagi: zmiana tytułu schematyzmu w stosunku do poz. 23; jęz. pol.

Oprawa: oryginalna - półtektura, półtwarda.

Sygn.: KUL V-8302/1997.

E. - , L. - Z. -

\section{BONIFRATRZY}

Bonifratrzy (Zakon Szpitalny św. Jana Bożego, Ordo Hospitalarius Sancti Joannis de Deo- $\mathrm{OH}$ ).

Założony został przez św. Jana Bożego w Grenadzie w 1540 r., zatwierdzony w 1572 r. Pierwszym miastem w Polsce, do którego zostali sprowadzeni bonifratrzy w 1609 r. przez mieszczanina W. Tamburiniego był Kraków. Prowincja polsko-litewska została erygowana w 1633 r. Po rozbiorach klasztory, które znalazły się na terenie Królestwa Polskiego zostały skasowane, natomiast klasztory z zaboru austriackiego zostały przyłączone w 1865 r. do prowincji austriacko-czeskiej. Prowincję polską reaktywowano w 1922 roku (IV.1).

W Bibliografii ujęto także dwa schematyzmy prowincji prusko-śląskiej (IV.2) w skład wchodziły domy zakonne leżące na dawnych ziemiach Rzeczypospolitej.

\section{IV.1. PROWINCJA POLSKA (od 1922 r.)}

1. Schematismus Ordinis St. Joannis de Deo (O.s.J.d.D.) almae Provinciae Poloniae Annuntiationis Beatae Mariae Virginis. Anno Domini 1925, Cracoviae [1924], [b.w.d.], 34 ss.

Treść: władze prowincji, Series [...] patrum provincialium ab erectione, skład osobowy poszcze- 
gólnych domów zakonnych, podsumowanie, Pie in Domino obierunt, Index religiosorum [...], Index religiosorum alphabeticus, członkowie honorowi, przegląd szpitali o.o. bonifratrów.

Oprawa: twarda, napis jak na str. tyt., herb zakonu. pol.

Uwagi: część schematyzmu dot. szpitali - w jęz.

Sygn.: KUL V-10454/1925.

E. - , L. - , Z. -

2. Schematismus almae Provinciae Polonicae Annuntitionis Beatae Mariae Virginis Ordinis Hospitalarii S. Joannis de Deo. Anno Domini 1937, Cracoviae [1936], [b.w.d.], 34 ss.

Treść: władze prowincji, historia zakonu (w jęz. polskim), Series [...] patrum provincialium, skład osobowy poszczególnych domów zakonnych, podsumowanie, Index praecedentiae religiosorum [...], Index religiosorum alphabeticus, Pie in Domino obierunt, członkowie honorowi, przegląd szpitali w pozostałych prowincjach.

Oprawa: jak w poz. 1.

Uwagi: zmiana tytułu schematyzmu w stosunku do poz. 1; jak w poz. 1.

Sygn.: KUL V-16752/1937.

E. -, L. - Z. poz. 726 .

\section{IV.2. PROWINCJA PRUSKO-ŚLĄSKA}

1. Schematismus Ordinis St. Joannis de Deo almae Provinciae Borusso-Silesiacae S. Caroli Borromaei et S. Hedwigis. Anno Domini 1908, Wratislaviae [1907], [b.w.], Typis Societatis „Schlesische Volkszeitung", $22 \mathrm{~cm}$., VII, 41 ss.

Treść: władze prowincji, Series [...] patrum provincialium ab erectione, skład osobowy poszczególnych domów zakonnych, zestawienie liczby zakonników, Defuncti, Religiosi [...], Index perosnarum, Allgemeine Uebersicht der Hospitäler der Barmherzigen Brüder (w jęz. niem.).

Oprawa: twarda, półpłótno, bogato zdobiona, tłoczona, złocenia, napis: „Schematismus Ordinis S. Joannie de Deo Provinciae Borusso-Silesicae 1908”, herb zakonu.

Uwagi: część schematyzmu dot. szpitali - w jęz. niem.
Sygn.: KUL V-10453/1908.

E. - , L.,- Z. -

2. Schematismus Ordinis St. Joannis de Deo (O.s.J.d.D.) almae Provinciae Borusso-Silesiae S. Caroli Borromaei et S. Hedwigis. Anno Domini 1925, Wratislaviae [1924], [b.w.], Typis Societatis „Schlesische Volkszeitung", $18 \mathrm{~cm}$., 40 ss.

Treść: jak w poz. 1.

Oprawa: tektura, twarda, napis jak na str. tyt., herb Zakonu.

Uwagi: zmiana tytułu schematyzmu w stosunku do poz. 1; jak w poz. 1.

Sygn.: KUL V-10453/1925.

E. - , L. - Z. -

\section{CHRYSTUSOWCY}

Chrystusowcy - Towarzystwo Chrystusowe dla Polonii Zagranicznej (Societatis Christi pro Emigrantibus Polonis - SChr lub TChr).

Zgromadzenie założone zostało przez kard. Augusta Hlonda w 1932 r. dla zapewnienia Polonii opieki duszpasterskiej. II wojna światowa spowodowała znaczne straty zarówno personalne, jak i majątkowe zgromadzenia. Szczególny rozkwit nastąpił dopiero po r. 1957, tak by od 1978 r. funkcjonowało już 6 prowincji zagranicznych.

1. [cz. 2] Towarzystwo Chrystusowe w Ameryce Południowej 1958-1988, oprac. Bernard Kołodziej TChr, [Curtiba 1987], [b.w.], composto e impresso no Gráfica Vincentia Ltda Almeda Cabral 846, $27 \mathrm{~cm}$, 96, [1] ss.

Treść: władze prowincji, skład osobowy poszczególnych domów zakonnych.

Oprawa: miękka.

Uwagi: zdjęcia.

Sygn.: KUL 384159II

E. -, L. -, Z. - 


\section{DOMINIKANIE}

\section{Zakon Kaznodziejski}

(Ordo Praedicatorum - OP).

Założony w I. ćwierci XIII w. przez św. Dominika Guzmana, przybył na ziemie polskie z inicjatywy św. Jacka Odrowąża ok. 1222 r. Od samego początku należał do najprężniej rozwijających się zakonów na ziemiach polskich. Już w 1225 r. została erygowana prowincja polska (VI.1. Prowincja polska przed rozbiorami), w roku 1612 - ruska, a w 1647 - litewska.

Po rozbiorach, początkowo najlepiej funkcjonowała prowincja litewska, którą w 1839 r. połączono z ruską. W wyniku kasat na ziemiach włączonych do Rosji, likwidacji uległy struktury prowincjalne, jednak pozostałe klasztory wydawały swoje druki (VI.4. Zakon w Rosji po 1864 r.) ale z klasztorów dominikańskich przetrwał jedynie klasztor w Petersburgu (do 1917 r.).

Prowincja polska w Królestwie Polskim (VI.2), której patronem był św. Jacek, to część dawnej prowincji polskiej i dawnej prowincji ruskiej, które znalazły się po 1815 roku na terytorium Kongresówki. Po 1864 r. rząd carski zniósł prawie wszystkie klasztory dominikańskie.

Do odzyskania przez Polskę niepodległości przetrwała tylko prowincja galicyjska (VI.3) na terenie zaboru austriackiego. Po pierwszej wojnie światowej, władze generalne Zakonu nie zezwalały na przejmowanie rewindykowanych domów zakonnych ani na utworzenie odrębnej prowincji. Sytuacja uległa zmianie dopiero w 1927 r., kiedy reaktywowano prowincję polską pw. św. Jacka (VI.5) oraz przywrócono jej w hierarchii zakonnej honorowe miejsce jednej z pierwszych 12 prowincji.

\section{VI.1. PROWINCJA POLSKA PRZED ROZBIORAMI (do 1795 r.)}

1. [cz. 1] Directorium divini officii iuxta ritum Sacri Ordinis Praedicatorum Provinciae Poloniae pro Anno Domini MDCXC [1690] per novissimam Sac. Ri- tuum Congregationis declarationem constitutum, [b.m. 1689], [b.w.d.], 14 cm., [72] ss., egz. interfol. [20] kk.

Treść: zarządzenia, zasadniczy zrąb kalendarza, modlitwy (w tym Lectiones), Dedicationum ecclesiarum Provinciae Poloniae Ord. Praed.

Uwagi: prywatne notatki w jęz. pol. (głównie o zjawiskach atmosferycznych) - pismo odręczne, atrament.

Oprawa: skóra, twarda, współoprawne z modlitewnikiem.

Sygn.: KUL P XVII.51.b

E. - L. -

\section{VI.2. PROWINCJA POLSKA W KRÓLESTWIE POLSKIM} (do 1864)

1. [cz. 1] Directorium recitandi divinum officium, missamque celebrandi juxta rubricas Breviarii et ritum Missalis Fratrum Ordinis Praedicatorum ad usum Provinciae Poloniae S. Hyacinthi pro anno bissextili 1836, [b.m. 1835], [b.w.d.], 17 cm., 48, [16] ss.

Treść: zasadniczy zrąb kalendarza.

[cz. 1a] Elenchus obitus magistrorum generalium $[\ldots],[8]$ ss.

[cz. 2] Catalogus patrum et fratrum, nec non monialium Sacri Ordinis Praedicatorum Provinciae Poloniae anno 1836 conscriptus, s. [9-16].

Treść: skład osobowy domów zakonnych, Fratres defuncti.

Uwagi: prywatne notatki.

Oprawa: miękka, papier.

Sygn.: KUL V-6842/1836.

E. cz. 1, t. I, s.316, L. -, Z. -

2. [cz. 1] Directorium [...] ad usum Provinciae Poloniae pro anno bissextili 1840, Varsaviae [1839], [b.w.d.], $17 \mathrm{~cm}$., 48, [10] ss.

Treść: władze zakonu, zasadniczy zrąb kalendarza. s. [1].

[cz. 1a] Fratres et sorores defuncti, 
[cz. 1b] Elenchus obitus magistrorum generalium [...], s. [3-10].

Oprawa: miękka, papier, napis atramentem: „Annus 1840”.

Uwagi: zmiana tytułu kalendarza w stosunku do poz. 1; prywatne notatki, karty z filigranami, cięte prawe dolne rogi kalendarza, brak części ostatniej karty.

Sygn.: KUL V-6842/1840.

E. - L. s. 397, Z. -

3. [cz. 1] Directorium recitandi divinum officium missamque celebrandi conformiter ad rubricas Breviarii et ritum Missalis fratrum Sacri Ordinis Praedicatorum, ad usum Provinciae Polonae S. Hyacinthi CPRP in annum 1850 2. post bissextilem, Varsaviae [1849], [b.w.], Typis Scholarum Piarum, 17 cm., 48, [8] ss.

Treść: zasadniczy zrąb kalendarza, Festa palatii imperialis majoris solemnitatis.

[cz. 1a] Obierunt in Domino [...], s. 48.

[cz. 2] Elenchus conventuum secudnum antiquitatis Ordinem, cum specifica nominatione religiosorum ac monialium in ijsdem [!] degentium Provinciae Polonae S. Hyacinthi CPRP Sacri Ordinis Praedicatorum in Annum Dni 1850, s. [49-56].

Treść: władze zakonu, skład osobowy domów zakonnych.

Uwagi: zmiana tytułu kalendarza w stosunku do poz. 2.

Oprawa: brak.

Sygn.: KUL V-6842/1850. KUL V-6856/1850 (jest oprawa).

E. cz. 1, t. IV, s. 123, L. -, Z. poz. 52.

4. [cz. 1] Directorium [...] in annum 1852 bissextilem, Varsaviae 1852, [b.w.], Ad Sanctam Crucem, 18 cm., 42, [2] ss.

Treść: zasadniczy zrąb kalendarza, Imperialis ac regalis palatii dies festivi. s. $41-42$.

[cz. 1a] Objerunt [!] in Domino [...],

Oprawa: miękka, papier, oryginalna.

Sygn.: KUL V-6842/1852.

E. - , L. - Z. -
5. Sygn. KUL V-6856/1852 - brak.

6. [cz. 1] Directorium divini officii recitandi missaeque celebrandae juxta ritum Sacri Ordinis Praedicatorum in Regno Poloniae pro Anno Domini $\mathbf{1 8 8 5}$ primo post bissextilem, Lublini [1884], [b.w.], Typis Michaelinae Kossakowska, 124, [1] ss.

Treść: zasadniczy zrąb kalendarza, Appendix [...], Decreta S.R.C, Praeparatio breviscula, Dies festivi papales, Dies festivi imperialis palatii, Phases lunae pro anno 1885, Tabella ortus et occasus [...].

[cz. 1a] Obierunt in Domino, s. 106.

Oprawa: twarda tektura, napis jak na str. tyt.

Uwagi: zmiana tytułu kalendarza w stosunku do poz. 3.

Sygn.: KUL V-6842/1885.

E. - , L. - , Z. -

\section{VI.3. PROWINCJA GALICYJSKA (1785-1918)}

1. [cz. 2] Schematismus patrum et fratrum S. Ordinis Praedicatorum Provinciae S. Hyacinthi in Regnis Galiciae \& Lodomeriae pro anno MDCCCLXV [1865], Leopoli 1865, [b.w.], Typis M. F. Poremba, $16 \mathrm{~cm} ., 8 \mathrm{ss}$.

Treść: Skład osobowy domów zakonnych.

Oprawa: papier, miękka, bez napisów.

Sygn.: KUL V-6856/1865.

E. - , L. - , Z. -

2. [cz. 2] Schematismus patrum et fratrum nec non monialium S. Ordinis Praedicatorum Provinciae S. Hyacinthi in Regnis Galiciae \& Lodomeriae et Magno Ducatu Cracoviensi pro anno 1874, [b.m. 1873], [b.w.d.], 16 cm., 24 ss.

Treść: jak w poz. 1 (w tym żeńskiego), [...] pie in Domino obierunt.

Uwagi: zmiana tytułu schematyzmu w stosunku do poz. 1.

Oprawa: papier, półmiękka, zdobiona, złocone brzegi kart.

Sygn.: KUL V-6856/1874.

E. -, L. -, Z. poz. 52 . 
3. [cz. 2] Schematismus patrum et fratrum Sacri Ordinis Praedicatorum Provinciae S. Hyacinthi in Regno Galiciae pro Anno Domini 1883, Leopoli 1882, [b.w.], Typis A. Wojdowicz (ant. Poremba), sub directione Felicis Bednarski, 16 cm., 19 ss.

Treść: jak w poz. 2, zestawienie liczby zakonników zakonników.

Uwagi: zmiana tytułu schematyzmu w stosunku do poz. 2; napis na pieczęci: „Z biblioteki Dra Franciszka Uhorczaka. 2996".

Oprawa: brak.

Sygn.: KUL V-6856/1883.

E. - , L. - , Z. poz. 52 .

4. [cz. 1] Ordo divini officii recitandi missaeque celebrandae juxta Ritum S. Ordinis Praedicatorum pro Anno Domini bissextili 1884 ad usum conventus et monasteriorum in Magno Ducatu Cracoviensi ataque in Przyrów existentium, Cracoviae 1884, sumptibus Ordinis Praedicatorum, E Typographia Związkowa sub directione A. Szyjewski, 17 cm., 64 ss.

Treść: zasadniczy zrąb kalendarza, Quaendam scitu necessaria.

[cz. 2] Catalogus fratrum ac sororum Sacri Ordinis Praedicatorum conventus et monasteriorum in Magno Ducatu Cracoviensi atque in Przyrów pro Anno Domini 1884, s. 53-64.

Treść: skład osobowy domów zakonnych (w tym żeńskich), Pie in Domino obiit, Hymnus de S. Hyacintho [...].

Uwagi: zmiana tytułu schematyzmu w stosunku do poz. 3.

Oprawa: miękka, papier, oryginalna.

Sygn.: KUL V-6842/1884.

E. - , L. - , Z. -

5. [cz. 1] Ordo divini officii recitandi, missaeque celebrandae juxta ritum S. Ord. Praedicatorum pro Anno Domini 1890 ad usum conventum Provinciae S. Hyacinthi in Regnis Galiciae et Lodomeriae Magnoque Ducatu Cracoviensi existentium, concinnavit p. fr. Franciscus Maria Różycki,
Leopoli 1889, [b.w.], Typis F. Bednarski (ant. Poremba), 16 cm., 74 ss., [1] k.

Treść: zasadniczy zrąb kalendarza.

Uwagi: zmiana tytułu kalendarza w stosunku do poz. 4.

Oprawa: tektura, półtwarda, napis jak na str. tyt.

Sygn.: KUL V-6842/1890.

E. - , L. - , Z. -

6. [cz. 2] Schematismus partum, fratrum sororumque Sacri Ordinis FFr. Praedicatorum almae Provinciae S. Hyacinthi in Regno Galiciae et Lodomeriae Magnoque Ducatu Cracoviensi pro Anno Domini 1892, Leopoli 1891, [b.w.], Typis Felicis Bednarski (ant. Poremba), 16 cm., 38, [7] ss., [1] k.

Treść: jak w poz. 2, Index alphabeticus patrum et fratrum.

Uwagi: zmiana tytułu schematyzmu w stosunku do poz. 4.

Oprawa: papier wydaw., miękka, napis jak na str. tyt.

Sygn.: KUL V-6856/1892.

E. -, L. -, Z. poz. 52 .

7. [cz. 2] Catalogus fratrum ac sororum Sacri Ordinis Praedicatorum almae Provinciae S. Hyacinthi in Galicia et Lodomeria Magnoque Ducatu Cracoviensi Anno Domini 1894 editus, Leopoli 1893, Sumpt. S. Ord. Ffr. Praed., Typis Felicis Bednarski (ant. Poremba), 16 cm., 61 ss.

Treść: jak w poz. 6 , Conspectus summarius.

Uwagi: zmiana tytułu schematyzmu w stosunku do poz. 6.

Oprawa: tektura, płótno, twarda, złote zdobienia, napis: „Schematismus S. Ordinis Ffr. Preadicatorum Provinciae S. Hyacintji 1894”; złocone brzegi kart.

Sygn.: KUL V-6856/1894.

E. - , L. - , Z. poz. 52 .

8. [cz. 2] Catalogus [...] Anno Domini 1901, Leopoli 1900, Sumpt. Ordinis Praedicatorum, Typis Felicis Bednarski, $16 \mathrm{~cm}$., 53 ss. 
Treść: jak w poz. 6.

Oprawa: półtektura, półmiękka, napis jak na str. tyt., z tyłu napis: „Lwów - 1900 z Drukarni Szczęsnego Bednarskiego Rynek L. 9”.

Sygn.: KUL V-6856/1901.

E. - , L. - Z. -

9. [cz. 2] Catalogus fratrum ac sororum Sacri Ordinis Praedicatorum almae Provinciae S. Hyacinthi in Regno Galiciae et Lodomeriae Magnoque Ducatu Cracoviensi pro Anno Domini 1908, Leopoli 1907, Sumpt. S. Ord. Ffr. Praedicatorum, Typis Felicis Bednarski, 17 cm., 59, [4] ss.

Treść: jak w poz. 6.

Uwagi: zmiana tytułu schematyzmu w stosunku do poz. 7.

Oprawa: tektura, półmateriał, twarda, zdobiona, złocony napis: „1908”, herb zakonu dominikanów.

Sygn.: KUL V-6856/1908.

E. - , L. - , Z. -

10. [cz. 1] Ordo divini officii recitandi missaeque celebrandae juxta ritum Sacri Ordinis Praedicatorum ad usum Provinciae S. Hyacinthi C.O.P. in Regnis Galiciae et Lodomeriae Magnoque Ducatu Cracoviensi pro Anno Domini 1913, Leopoli 1913, Sumpt. Ordinis Praed., Typis Felicis Bednarski, $16 \mathrm{~cm} ., 84 \mathrm{ss}$.

Treść: jak w poz. 5.

Uwagi: zmiana tytułu kalendarza w stosunku do poz. 5.

Oprawa: tektura, półtwarda, napis jak na str. tyt.

Sygn.: KUL V-6842/1913.

E. - , L. - , Z. -

11. [cz. 2] Catalogus [...] pro Anno Domini 1913, Leopoli 1912, Sumpt. Ordinis Praed., Typis F. Bednarski, 14 cm., 63 ss.

Treść: jak w poz. 6 .

Uwagi: Pieczęcie:1. Owalna, napis: „FÖLÖSPÉLDÁNY OSZK Fölöspéldány Közpöné”; 2. Okrągła, napis: „BIBLIOTECA Fr. Fr. Ord. Praed. Conv....." nazwa domu zakonnego nieczytelna.
Oprawa: półtwarda, półtektura, napis jak na str. tyt., z tyłu znak drukarni i napis: „Z Drukarni Szczęsnego Bednarskiego, Lwów, Rynek L. 9".

Sygn.: KUL V-6856/1913.

E. - , L. -, Z. -

12. [cz. 1] Ordo [...] pro Anno Domini 1916, Leopoli 1915, Sumpt. S. Ordinis. Praed., Typis Felicis Bednarski, $16 \mathrm{~cm}$., 104 ss.

Treść: zasadniczy zrąb kalendarza, Notanda.

Uwagi: $\mathrm{z}$ tyłu na okładce znak drukarni.

Oprawa: papier wydaw., półtwarda, napis jak na str. tyt.

Sygn.: KUL V-6842/1916.

E. - , L. -, Z. -

13. [cz. 2] Catalogus [...] pro Anno Domini 1917, Leopoli 1917, Sumpt. Ordinis Praed., Typis Felicis Bednarski, 16 cm., 33, [7] ss.

Treść: jak w poz. 6.

Oprawa: papier wydaw., półtwarda, napis jak na str. tyt.

Sygn.: KUL V-6856/1917.

E. -, L. -, Z. -

14. [cz. 2] Catalogus [...] pro Anno Domini 1918, Leopoli 1918, Sumpt. Ordinis Praed., Typis Felicis Bednarski, 16 cm., $34,[6]$ ss.

Treść: jak w poz. 6 .

Oprawa: papier wydaw., półtwarda, napis jak na str. tyt., z tyłu znak drukarni i napis: „Z Drukarni Szczęsnego Bednarskiego, Lwów, Rynek L. 9”.

Sygn.: KUL V-6856/1918.

E. -, L. -, Z. -

\section{VI.4. ZAKON W ROSJI (po 1864)}

1. [cz. 1] Ordo peragendi sacri et divini officii recitandi proprius Sacro Ordini Praedicatorum usibus diocesum conformatus in annum MDCCCLXXVII [1877], Vilnae 1876, [b.w.], Typis Josephi Zawadzki, 17 cm., 86 ss.

Treść: zasadniczy zrąb kalendarza (w jęz. łac., ros.), święta państwowe (w jęz. ros.), Modus dicendi 
preces in festis palatii, modlitwy (w jęz. łac. i ros.), spis zakonników i zakonnic (w jęz. łac. i ros.).

[cz.2] Священники Доминиканского Ордена (w jęz. ros.), s. 83-86.

Treść: wykaz zakonników i zakonnic, wykaz zmarłych w jęz. ros.

Oprawa: brak.

Sygn.: KUL V-6842/1877.

E. - , L. - , Z. -

\section{VI.5. ZAKON W II RZECZYPOSPO- LITEJ (1918-1927). PROWINCJA POLSKA (1927-)}

1. [cz. 2] Catalogus fratrum ac sororum Sacri Ordinis Praedicatorum almae Provinciae S. Hyacinthi in Polonia pro Anno Domini 1920, Leopoli 1920, Sumpt. Ordinis. Praed., Typis A. Bednarski, 17 cm., 35, [1] ss., [2] kk.

Treść: skład osobowy domów zakonnych (w tym żeńskich), wykaz zmarłych.

Oprawa: papier, miękka, napis jak na str. tyt., herb zakonu, z tyłu znak drukarni.

Sygn.: KUL V-6856/1920.

E. - , L. - , Z. poz. 52 .

2. [cz. 2] Catalogus conventum ac domorum Sacri Ordinis Praedicatorum almae Provinciae S. Hyacinthi in Polonia pro Anno Domini 1925, Leopoli [1924], sumptibus Ordinis, [b.d.], $14 \mathrm{~cm} ., 37$, [2] ss.

Treść: jak w poz. 1 .

Uwagi: zmiana tytułu schematyzmu w stosunku do poz. 1.

Oprawa: papier, miękka, oryginalna, napis: "Catalogus 1925".

Sygn.: KUL V-6856/1925.

E. -, L. -, Z. poz. 52 .

3. [cz. 2] Catalogus fratrum ac sororum Sacri Ordinis Praedicatorum Provinciae S. Hyacinthi in Polonia Anno Domini 1927, Leopoli [1927], sumptibus Ordinis Praedicatorum, [Typis Soc. S. Michaelis Archang. in Miejsce Piastowe], 23 cm., 31, [1] ss.
Treść: jak w poz. 1.

Uwagi: zmiana tytułu schematyzmu w stosunku do poz. 2; nazwa drukarni uzupełniona $\mathrm{z}$ treści schematyzmu.

Oprawa: papier, miękka, oryginalna, napis jak w tyt. bez miejsca wyd. i wydawcy, przedstawienie Matki Boskiej z Dzieciątkiem i św. Jacka, herb zakonu, z tyłu znak drukarni z napisem:,, Zakłady Graficzne Michalineum w Miejscu Piastowym".

Sygn.: KUL V-6856/1927.

E. - , L. - , Z. poz. 52 .

4. [cz. 2] Catalogus fratrum ac sororum Provinciae Poloniae Sacri Ordinis Praedicatorum Anno Domini 1928, Leopoli 1928, sumptibus Ordinis Praedicatorum, [Druk „Michalineum” Miejsce Piastowe], $17 \mathrm{~cm} ., 31 \mathrm{ss}$.

Treść: jak w poz. 1.

Uwagi: zmiana tytułu schematyzmu w stosunku do poz. 3; nazwa drukarni uzupełniona $\mathrm{z}$ treści schematyzmu.

Oprawa: papier, miękka, oryginalna, napis jak w tytule, herb prowincji, z tyłu znak drukarni z napisem: „Wydawnicze Zakłady Graficzne T[owarzyst]wa św. Michała Archanioła w Miejscu Piastowem”.

Sygn.: KUL V-6856/1928.

E. -, L. -, Z. poz. 52 .

5. [cz. 2] Catalogus [...] Anno Domini MCMXXXVII [1937], Leopoli 1937, [b. w.], Officina Typogr. O. P., 18 cm., 50 ss., [1] k.

Treść: jak w poz. 1, Kongragacja SS. Dominikanek III Zakonu.

Oprawa: papier, miękka, oryginalna, napis jak na str. tyt., herb prowincji.

Sygn.: KUL V-6856/1937.

E. - , L. - , Z. poz. 52 .

6. [cz. 1] Ordo divini officii recitandi missaeque celebrandae juxta ritum S. Ordinis Praedicatorum pro Anno Domini 1944 ad usum Provinciae Poloniae, superiorum permissu, Lublini 1943, sumptibus Provinciae, Deutsche Buchdruckerei „Tempo”, $17 \mathrm{~cm} .$, IV, $151 \mathrm{ss}$.

Treść: zasadniczy zrąb kalendarza. 
Oprawa: papier, miękka, napis jak na str. tyt.

Sygn.: KUL V-6842/1944.

E. - , L. - , Z. -

7. [cz. 2] Provinciae Poloniae Ordinis Praedicatorum catalogus conventuum et fratrum. Status pro die 1 Ianuarii 1981, Varsaviae [1980], E Curia Provincialis, [b. d.], $17 \mathrm{~cm} ., 191 \mathrm{ss}$.

Treść: Conspectus historicus Provinciae, Series chronologica priorum provincialum, Provincialia officia, Indices fratrum, Moniales Ordinis Paedicatorum, Necrologium, Appendix.

Uwagi: zmiana tytułu schematyzmu w stosunku do poz. 4.

Oprawa: papier, miękka, oryginalna, napis jak na str. tyt. bez miejsca wydania i wydawcy.

Sygn.: KUL V-25263/1981.

E. - , L. - Z. - , W. poz. 310 .

8. [cz. 1] Kalendarz liturgiczny Polskiej Prowincji Dominikanów na rok 1988, oprac. Józef Paściak OP, Warszawa 1987, Kuria Prowincjalna, 20 cm., 107, [1] ss.

Treść: jak w poz. 6 .

Oprawa: papier, miękka.

Uwagi: zmiana tytułu kalendarza w stosunku do poz. 6; maszynopis.

Sygn.: KUL V-6842/1988.

E. - , L. - , Z. -

9. [cz. 1] Kalendarz [...] na rok 1989, oprac. Józef Paściak OP, Warszawa 1988, Kuria Prowincjalna, 20 cm., 112 ss.

Treść: jak w poz. 6.

Oprawa: papier, miękka, napis jak na str. tyt.

Uwagi: maszynopis.

Sygn.: KUL V-6842/1989.

E. - , L. - , Z. -

\section{FILIPINI (ORATORIANIE)}

\section{Kongregacja Oratorium św. Filipa Neri}

(Congregatio Oratorii Sancti Philippi Neri - COr.).

Początek Kongregacji sięga roku 1575, kiedy to została zatwierdzona przez papie- ża Grzegorza XIII grupa kapłanów pracująca pod kierunkiem św. Filipa Neri.

$\mathrm{Na}$ ziemiach polskich rozpoczęli działalność w 1668 r. Po kasacie w XIX wieku wszystkich kongregacji, odnowiła swoją działalność placówka w Gostyniu. W roku 1945 filipni polscy dołączyli do Instytutu Oratorium w Rzymie.

1. Sygn.: KUL V-33447/1989 - brak.

2. [cz. 2] Schematyzm Federacji Kongregacji Oratorium św. Filipa Neri [1993], red. Zbigniew Starczewski, Poznań [1992], Federacja Kongregacji Oratorium św. Filipa Neri w Polsce, Wydawnictwo-Drukarnia „Bonami”, 18 cm., 126 ss.

Treść: władze Zakonu, skład osobowy poszczególnych domów, adresy, szereg informacji dodatkowych.

Oprawa: papier wydaw.

Sygn.: KUL V-33447/1993.

E. -, L. - Z. Z

3. [cz. 2] Schematyzm Federacji Kongregacji Oratorium św. Filipa Neri [1997], red. Zbigniew Starczewski, [Poznań 1997, Federacja Kongregacji Oratorium św. Filipa Neri w Polsce, Wydawnictwo-Drukarnia „Bonami”], 17 cm., 126 ss.

Treść: jak w poz. 1.

Uwagi: zmiana tytułu schematyzmu w stosunku do poz. 2.

Oprawa: papier wydaw., półmiękka.

Sygn.: KUL V-33447/1997.

E. - , L. - , Z. -

\section{FRANCISZKANIE KONWENTUALNI}

\section{Zakon Braci Mniejszych Konwentual- nych (Ordo Fratrum Minorum Conventu- alium - OFM Conv.).}

Zakon założony w 1209 r. we Włoszech przez św. Franciszka z Asyżu pod nazwą Braci Mniejsych. W 1517 r. został dokonany oficjalny podział na franciszka- 
nów obserwantów i konwentualnych. Do rozbiorów franciszkanie posiadali w Rzeczypospolitej 3 prowincje: polską, ruską i litewską. Po 1797 r. w wyniku zmian granic prowincji mamy do czynienia już z pięcioma jednostkami: pruską, Galicji Wschodniej, Galicji Zachodniej (dwie ostatnie połączone w 1806 r. w prowincję Obojga Galicji), ruską i litewską (połączone unią w 1819 r.).

Po zmianach granic państwowych, jakie nastapiły według ustaleń Kongresu Wiedeńskiego, w 1810 r. do prowincji polskiej (pruskiej) przyłączono część domów zakonnych prowincji Galicji Wschodniej i Galicji Zachodniej. Przetrwała ona na terenie Kongresówki do 1864 r., kiedy to została skasowana przez władze rosyjskie (VIII.2. Prowincja polska w Królestwie Polskim). W zbiorze BU KUL jest to zapewne ostatnie directorium tej prowincji, do którego dołączono też pełny schematyzm.

W wyniku kasat jedyną prowincją, jaka przetrwała do odzyskania przez Polskę niepodległości, była prowincja galicyjska (VIII.1) obejmująca klasztory należące do części prowincji Galicji Wschodnej. Dała ona tym samym początek prowincji polskiej w II Rzeczypospolitej (VIII.3).

Po I wojnie światowej nastapił intensywny okres rewindykacji skasowanych klasztorów franciszkańskich oraz rozwój zakonu na ziemiach polskich. Już w roku 1920 prowincja polska posiadała 4 kustodie funkcjonujące $w$ jej ramach. W 1939 r. doszło do podziału prowincji na malopolską (VIII.4) (zwana też krakowską) pw. św. Antoniego z Padwy i bł. Jakuba Strepy oraz wielkopolsko-mazowiecką (warszawska) pw. Niepokalanego Poczęcia NMP (VIII.4). Z tej z kolei w 1986 r. wydzielono prowincję pw. św. Maksymiliana Marii Kolbego, która obejmuje przede wszystkim ziemie północne Polski (VIII.4). Ze względu, iż część kalendarzy dotyczy więcej niż jednej prowincji, zdecydowano sie ujać je razem. Z kolei osobno wyszczególniono schematyzmy prowincji po 1939 r. (VIII.5 Schematyzmy franciszkanów konwentualnych po 1939 r.).

\section{VIII.1. PROWINCJA GALICYJSKA (1809-1918)}

1. [cz. 1] Directorium divini officii recitandi juxta rubricas Breviarii et Missalis Romani ad usum PP. et FF. Ordinis Minorum S.P.N. Francisci Conventualium, nec non Monialium S. Clarae in Provincia S. Antonii Pad. in Regnis Galiciae et Lodomeriae pro anno a nativitate Christi MDCCCLVIII [1858], post bissextilem et embolismalem secundo, Leopoli [1857], [b.w.], Typis E. Winiarz, 19 cm., [38] ss.

Treść: zasadniczy zrąb kalendarza, Lunationes, Tabella ortus [...].

[cz. 2] Schematismus Ordinis Minorum S.P. Francisci Conventualium, Provinciae S. Antonii Paduani, in Regnis Galiciae et Lodomeriae, nec non Monialium S. Clarae 1858, s. [33-38].

Treść: skład osobowy poszczególnych domów zakonnych, Sancti Rochi Confessoris dxm (s. [21]).

Oprawa: papier, miękka.

Sygn.: KUL V-10554/1858.

E. cz. 1, t. I, s. 314, L. -, Z. -

2. [cz. 2] Album Fratrum Minorum S. Francisci Conventualium nec non Sororum Ordinis S. Franc. Clarissarum almae Provinciae Galicianae pro Anno Domini 1889, Cracoviae 1889, Sumpt. PP. Minor. S. Fr. Conventualium, Typis Universitatis Jagellonicae, provisore A. M. Kosterkiewicz, 20 cm., 16 ss.

Treść: władze prowincji, skład osobowy poszczególnych domów zakonnych (w tym żeńskich), wykaz zmarłych, zestawienie liczby zakonników.

Uwagi: zmiana tytułu schematyzmu w stosunku do poz. 1; napis ołówkiem na str. tyt.: [Schematismus].

Oprawa: brak.

Sygn.: KUL V-15980/1889.

E. - , L. - , Z. - 


\section{VIII.2. PROWINCJA POLSKA W KRÓLESTWIE POLSKIM} (do 1864)

1. [cz. 1] Directorium divini officii sacrisque sacrificiis rite persolvendis, juxta rubricas generales et peculiares tam Breviarii quam Missalis nec non Sacrae Ritum Congregationis ad usum Seraphici Ordinis Minorum S.P. Francisci Conventualium et Monialium S. Clarae Virginis ac Tertii Ordinis utriusque sexus authoritate A.R.P.M. Francisci Wołyniec ministri provincialis ac commissarii generalis pro anno a nativitate Christi MDCCCLXIV [1864] ipso bissextili et embolismali pro Provinica in Regno Poloniae dispositum, Cracoviae [1863], [b.w.], Typis Ż. J. Wywiałkowski, 19 cm., 100 ss.

Treść: Ritus servandus in celebratione [...], De divino officio rite [...], Analityca temporum computatio, zasadniczy zrąb kalendarza.

[cz. 1a] Cathalogus partum, fratrum et sororum in annis 1861-62 et 1863 mortuorum, s. [93a].

[cz. 2] Elenchus partum et fratrum $\mathrm{O}$. N. Conventualium Provinciae nostrae Polonae in fine 1863 a. descriptus, s. [94-100].

Treść: skład osobowy poszczególnych domów zakonnych (w tym żeńskiego), zestawienie liczby zakonników.

Oprawa: papier, miękka.

Sygn.: KUL V-10554/1864.

E. cz. 1, t. I, s. 314 , L. s. 403- 404, Z. -

\section{VIII.3. PROWINCJA POLSKA W II RZECZYPOSPOLITEJ} (1918-1939)

1. [cz. 2] Schematismus Fratrum Minorum S. Francisci Conventualium (OO. Franciszkanów) Provinciae S. Antonii Patavini et S. Jacobi Strepa in Polonia A.D. 1930, Niepokalanów 1930, Typis „Rycerz Niepokalanej", 20 cm., 39 ss.

Treść: władze zwierzchnie, skład osobowy poszczególnych domów zakonnych (w tym żeńskich), zestawienie liczby zakonników, Obierunt in Domino.
Oprawa: papier wydaw., napis jak na str. tyt.

Sygn.: KUL V-11396/1930.

E. -, L. s. 406, Z. poz. 728 .

2. [cz. 2] Elenchus Fratrum Minorum S. Francisci Conventualium (OO. Franciszkanie) Provinciae S. Antonii Patavini et B. Jacobi de Strepa nec non Monialium S. Clarae pro Anno Domini 1935, Niepokalanów [1934], [b.w.], Typographia „Rycerz Niepokalanej", 19 cm., 84 ss.

Treść: jak w poz. 1, skład osobowy domów zakonnychzeszczególnymuwzględnieniemuczniówistudentów, Extra Provinciam degentes, Index patrum et fratrum, Index sororum.

Uwagi: zmiana tytułu schematyzmu w stosunku do poz. 1.

Oprawa: papier wydaw., napis jak na str. tyt.

Sygn.: KUL V-11396/1935.

E. -, L. -, Z. poz. 728 .

3. [cz. 2] Elenchus [...] pro Anno Domini 1936, Cracoviae [1935], [b.w.], Typographia „Powściągliwość i Praca”, 19 cm., 39 ss.

Treść: jak w poz. 2.

Oprawa: papier wydaw., napis podobny, jak na str. tyt.

Sygn.: KUL V-11396/1933.

E. -, L. - , Z. poz. 728 .

VIII.4. PROWINCJA MALOPOLSKA (1939-)

PROWINCJA WIELKOPOLSKA (1939-)

\section{PROWINCJA ŚW. MAKSYMILIANA} MARII KOLBEGO (1986-)

\section{Kalendarze}

1. [cz. 1] Ordo divini officii Fratrum Min. Conv. ac Mon. S. Clarae in Prov. S. Antonii Pat. et B. Jacobi de Strepa atque in Prov. Immac. Conc. BMV. 1941, [b.m. 1940], [b.w.d.], 17 cm., 137 ss.

Treść: zasadniczy zrąb kalendarza.

Oprawa: papier, twarda.

Uwagi: zmiana tytułu kalendarza; na okładce 
notatki odręczne ołówkiem, brak tylnej okładki, tekst pisany maszynowo.

Sygn.: KUL-V 8886/1941.

E. -, L. - , Z. -

2. [cz. 1] Ordo divini officii presolvendi sacrique peragendi ad usum Fratrum Minorum Conventualium ac Monialium S. Clarae in Prov. S. Antonii Pat. et B. Jacobi de Strepa E.C. ac in Prov. Immaculatae Conceptionis B. Mariae Virginis pro Anno Domini 1943, [b.m. 1942], [b.w.], Warszawa - dr. J. Domagalski i Z. Frączkowski Elektoralna 3, $17 \mathrm{~cm} ., 81$ ss.

Treść: jak w poz. 1.

Proweniencja: Br. Innocenty - napis odręczny atramentem.

Uwagi: zmiana tytułu kalendarza w stosunku do poz. 1; na wewnętrznej okładce pieczęć Zakonu z napisem: „Novitiatus Ord. Fr. Min. S. Francisco Conv. in Polonia".

Oprawa: papier, miękka.

Sygn.: KUL-V 8886/1943.

E. -, L. - , Z. -

3. [cz. 1] Ordo [...] pro Anno Domini 1946, [b.m. 1945], [b.w.], [Niepokalanów - Typographia „Rycerz Niepokalanej”], 16 cm., 131 ss.

Treść: jak w poz. 1.

Proweniencja: „Br. Innocenty” - napis odręczny atramentem.

Uwagi: na wewnętrzenej okładce pieczęć Zakonu z napisem: „Novitiatus Ord. Fr. Min. S. Francisco Conv. in Polonia", adres wydawniczy uzupełniony $\mathrm{z}$ treści kalendarza.

Oprawa: papier wydaw., napis: „Ordo 1946, Typographia 'Rycerz Niepokalanej', Niepokalanów ad Varsaviam".

Sygn.: KUL-V 8886/1946.

E. - , L. - , Z. -

4. [cz. 1] Ordo divini officii presolvendi sacrique peragendi ad usum Fratrum Minorum Conventualium ac Monialium S. Clarae in Prov. S. Antonii Pat. et B. Jacobi de Strepa E.C. ac in Prov. Immaculatae Conceptionis B. Mariae Virginispro Anno
Domini 1947 auctoritate Adm. R.P. dr. Hadriani Leduchowski commissarii generalis dispositus, [b.m. 1946] [b.w.], Niepokalanów - Typogr. Militia Immaculatae, 15 cm., 121, [7] ss.

Treść: jak w poz. 1

Uwagi: zmiana tytułu kalendarza w stosunku do poz. 2; nazwa drukarni uzupełniona $\mathrm{z}$ treści kalendarza.

Oprawa: brak.

Sygn.: KUL-V 8886/1947.

E. - , L. - , Z. -

5. [cz. 1] Ordo divini officii presolvendi sacrique peragendi ad usum Fratrum Minorum Conventualium ac Monialium S. Clarae in Prov. S. Antonii Pat. et B. Jacobi de Strepa E.C. ac in Prov. Immaculatae Conceptionis B. Mariae Virginis pro Anno Domini 1948 auctoritate Adm. R.P. dr. Hadriani Leduchowski ministri provincialis dispositus, [b.m. 1947], [b.w.], Niepokalanów - Typographia Militia Immaculatae, $15 \mathrm{~cm} ., 124$, [4] ss.

Treść: jak w poz. 1 .

Uwagi: zmiana tytułu kalendarza w stosunku do poz. 4; nazwa drukarni uzupełniona $\mathrm{z}$ treści kalendarza.

Oprawa: papier wydaw., napis: Ordo 1948, Typographia „Rycerz Niepokalanej”, Niepokalanów ad Varsaviam.

Sygn.: KUL-V 8886/1948

E. - , L. - , Z. -

6. [cz. 1] Ordo [...] pro Anno Domini 1949 [...], [b.m. 1948], [b.w.], Niepokalanów - Typogr. Militia Immaculatae, 15 cm., 135 ss.

Treść: jak w poz. 1.

Oprawa: papier wydaw., napis: „Ordo 1949, Typographia „Rycerz Niepokalanej”, Niepokalanów ad Varsaviam.

Sygn.: KUL-V 8886/1949.

E. - , L. - , Z. -

7. [cz. 1] Ordo [...] pro Anno Domini 1950 [...], [b.m. 1949], [b.w.], [Kraków Typogr. „Patria”], 15 cm., 80 ss. 
Treść: jak w poz. 1.

Proweniencja: „Fr. Daniel [........ ” [!] - nazwisko nieczytelne.

Uwagi: tytuł uzupełniony z treści kalendarza.

Oprawa: papier wydaw., napis, jak na str. tyt.

Sygn.: KUL-V 8886/1950.

E. - , L. - , Z. -

8. [cz. 1] Ordo divini officii presolvendi sacrique peragendi ad usum Fratrum Minorum Conventualium ac Monialium S. Clarae in Polonia pro Anno Domini 1951 auctoritate Adm. R.P.M. Hadriani Leduchowski Prov. Immcul. Conceptionis B. M.V. ministri provincialis dispositus, [b.m. 1950], [b.w.d.], 20 cm., 83 ss.

Treść: jak w poz. 1.

Uwagi: zmiana tytułu kalendarza w stosunku do poz. 5; nie ma strony tytułowej, tytuł z okładki, adnotacja: „Zamiast rękopisu [...]”, maszynopis.

Oprawa: jak w poz. 7.

Sygn.: KUL-V 8886/1951.

E. - , L. - , Z. -

9.[cz. 1] Ordo divini officii recitandi sacrique peragendi ad usum Fratrum Minorum S. Francisci Conventualium utriusque Provinciae Polonae ac Monialium S. Clarae pro Anno Domini 1952 iussu et auctoritate Rmi. P.M. Hadriani Leduchowski ministri provincialis iuxta recenter approbatum kalendarium eiusdem Ordinis dispositus, [b.m. 1951], [b.w.d.], 15 cm., 143 ss.

Treść: jak w poz. 1.

Oprawa: papier wydaw., napis: „Ordo 1952. Niepokalanów".

Uwagi: zmiana tytułu kalendarza w stosunku do poz. 8; adnotacja: ,Zamiast rękopisu [...]”, maszynopis, ostatnia strona błędnie numerowana: 134 [!], powinno być 143 .

Sygn.: KUL-V 8886/1952.

E. - , L.,- Z. -

10. [cz. 1] Ordo divini officii recitandi sacrique litandi pro Provincia Immaculatae Conceptionis BMV. et S. Antonii Pat. et B. Jacobi de Strepa Ordinis Fratrum Minorum S. Francisci Convent. in Polonia [annus
Domini 1957] iussu et auctoritate Adm. R. Mi. p. Augusti Rosiński ministri provincialis, [b.m. 1956] [b.w.], Drukarnia Loretańska, $14 \mathrm{~cm} ., 112 \mathrm{ss}$.

Treść: jak w poz. 1 .

Uwagi: zmiana tytułu kalendarza w stosunku do poz. 9.

Oprawa: jak w poz. 7.

Sygn.: KUL-V 8886/1957.

E. - , L. - , Z. -

11. [cz. 1] Ordo divini officii presolvendi sacrique peragendi ad usum Fratrum Minorum Conventualium ac Monialium S. Clarae in Provincia S. Antonii Pat. et B. Jacobi de Strepa E.C. ac in Prov. Immaculatae Conceptionis B. Mariae Virg. [pro Anno Domini 1959] auctoritate Adm. R.P. Augusti Rosiński ministri provincialis, [b. m. 1958], [b.w.], Drukarnia im. Rewolucji Październikowej, 15 cm., 114 ss.

Treść: jak w poz. 1.

Proweniencja: Biblioteka UMCS Lublin.

Uwagi: zmiana tytułu kalendarza w stosunku do poz. 10.

Oprawa: jak w poz. 7.

Sygn.: KUL-V 8886/1959.

E. - , L. - , Z. -

12. [cz. 1] Ordo divini officii presolvendi sacrique peragendi ad usum Fratrum Minorum Conventualium ac Monialium S. Clarae in Provincia S. Antonii Pat. et B. Jacobi de Strepa E.C. ac in Prov. Immaculatae Conceptionis B. Mariae Virg. [pro Anno Domini 1960] auctoritate Adm. R.P. Titi Strzelewicz ministri provincialis, [Warszawa 1959], [b.w.], Drukarnia Loretańska, 15 cm., 95 ss.

Treść: jak w poz. 1.

Uwagi: zmiana tytułu kalendarza w stosunku do poz. 11.

Oprawa: jak w poz. 7.

Sygn.: KUL-V 8886/1960.

E. - , L. - , Z. -

13. [cz. 1] Ordo [...] [pro Anno Domini 1961] [...], [b.m. 1960], [b.w.], Drukar- 
nia Loretańska, 15 cm., 93 ss.

Treść: jak w poz. 1.

Oprawa: jak w poz. 7.

Sygn.: KUL-V 8886/1961.

E. -, L. - , Z. -

14. [cz. 1] Ordo [...] [pro Anno Domini 1962] [...], [b.m. 1961], [b.w.], K.Z.G., Zakł. 3, 15 cm., 104 ss.

Treść: jak w poz. 1 .

Oprawa: jak w poz. 7.

Sygn.: KUL-V 8886/1962.

E. - L. - , Z. -

15. Sygn.: KUL-V 8886/1963 - brak.

16. [cz. 1] Ordo [...] [pro anno bissextili 1964] [...], [b.m. 1963], [b.w.], Drukarnia Loretańska, $15 \mathrm{~cm} ., 87 \mathrm{ss}$.

Treść: jak w poz. 1.

Uwagi: tytuł kalendarza, jak w poz. 12 ze zmianą - zamiast [...] ad usum Fratrum Minorum Conventualium, jest: $[\ldots]$ ad usum Fratrum Minorum Conventualium (OO. Franciszkanów) [...].

Oprawa: jak w poz. 7.

Sygn.: KUL-V 8886/1964.

E. - , L. - , Z. -

17. [cz. 1] Ordo divini officii presolvendi sacrique peragendi ad usum Fratrum Minorum Conventualium ac Monialium S. Clarae in Provinca [!] Immac. Conc. B. M.V. et in Provincia S. Antonii Pat. ac Monialium S.M. Clarae pro anno bissextili 1968 auctoritate Adm. R.P. mgr Lutoslai Pieprzycki et Adm. R.P. dr Mariani Lisowski ministrorum provincialium, A.R.P. Gerardo Domka def. prep. digestus, [b.m. 1967], [b.w.], Drukarnia Wydawnicza w Krakowie, 15 cm., 117, [2] ss.

Treść: jak w poz. 1 .

Uwagi: zmiana tytułu kalendarza w stosunku do poz. 14; errata.

Oprawa: jak w poz. 7.

Sygn.: KUL-V 8886/1968.

E. - , L. - , Z. -

18. [cz. 1] Ordo divini officii presol- vendi sacrique peragendi ad usum Fratrum Minorum Conventualium ac Monialium S. Clarae in Provinca [!] Immac. Conc. B. M.V. et in Provincia S. Antonii Pat. ac Monialium S.M. Clarae pro Anno Domini 1969 auctoritate Adm. R.P. Ladislai Ryguła et Adm. R.P. Ludovici Szetela ministrorum provincialium, A.R.P. Gerardo Domka def. prep. digestus, [b.m. 1968], [b.w.], Drukarnia Wydawnicza w Krakowie, 15 cm., 124 ss.

Treść: wprowadzenie, jak w poz. 1

Uwagi: zmiana tytułu kalendarza w stosunku do poz. 17; jęz. pol., łac.

Oprawa: jak w poz. 7.

Sygn.: KUL-V 8886/1969.

E. - , L. - , Z. -

19. [cz. 1] Kalendarz liturgiczny dla Prowincji OO. Franciszkanów oraz dla sióstr klarysek w Polsce na rok przestępny 1972, z upoważnienia o. mgr Mariusza Paczóskiego i o. dr Joachima Bara zredagował o. Gerard Domka def. jubilat, [b.m. 1971], [b.w.], Drukarnia Związkowa, 15 cm., 107, [9] ss.

Treść: instrukcje, jak w poz. 1.

Uwagi: zmiana tytułu kalendarza w stosunku do poz. 18; jęz. pol., łac.

Oprawa: papier, twarda, napis podobny, jak na str. tyt.

Sygn.: KUL-V 18537/1972.

E. -, L. -, Z. -

20. [cz. 1] Kalendarz liturgiczny Zakonu OO. Franciszkanów oraz sióstr klarysek na rok Pański 1973, oprac. oo. Gerard Domka, Juliusz Wierzbicki, Kraków-Warszawa 1972, [b.w.], Drukarnia Tarnów, 15 cm., 144 ss

Treść: instrukcje, jak w poz. 1, uzupełnienia.

Uwagi: zmiana tytułu kalendarza w stosunku do poz. 19; jęz. pol., łac.

Oprawa: jak w poz. 19.

Sygn.: KUL-V 18537/1973.

KUL-V 18886/1973.

E. -, L. - , Z. - 
21. [cz. 1] Kalendarz liturgiczny Zakonów Franciszkańskich w Polsce na rok Pański 1974, [oprac. o. Juliusz Wierzbicki OFM Conv.], Kraków [1973], [prowincjałowie Prowincji Zakonu Serafickiego w Polsce], Krakowskie Zakłady Graficzne nr 1, 14 cm., 191 ss.

Treść: wprowadzenie, jak w poz. 1, kalendarz terytorialny.

Uwagi: zmiana tytułu kalendarza w stosunku do poz. 20; jęz. pol., uzupełnienie adresu wydawniczego $\mathrm{z}$ treści kalendarza.

Oprawa: jak w poz. 19.

Sygn.: KUL-V 18537/1974.

E. - , L. - , Z. -

22. [cz. 1] Kalendarz [...] na rok Pański 1975, [oprac. o. Juliusz Wierzbicki OFM Conv.], Kraków [1974], [prowincjałowie Prowincji Zakonu Serafickiego w Polsce], Krakowskie Zakłady Graficzne nr 3, 15 cm., 252 ss.

Treść: wprowadzenie, jak w poz. 1.

Uwagi: zmiana tytułu kalendarza w stosunku do poz. 21 ; jęz. pol., łac.; uzupełnienie adresu wydawniczego z treści kalendarza.

Oprawa: jak w poz. 19.

Sygn.: KUL-V 18537/1975.

E. - , L. - , Z. -

23. [cz. 1] Kalendarz [...] na rok Pański 1976, [oprac. o. Juliusz Wierzbicki OFM Conv.], Kraków [1975], [prowincjałowie ProwincjiZakonu Serafickiego w Polsce], Krakowskie Zakłady Graficzne nr 3, 14 cm., 185, [3] ss.

Treść: wprowadzenie, jak w poz. 1, [dodatek].

Uwagi: jęz. pol., łac.; uzupełnienie adresu wydawniczego $\mathrm{z}$ treści kalendarza.

Oprawa: jak w poz. 19.

Sygn.: KUL-V 18537/1976.

E. - , L. - , Z. -

24. [cz. 1] Kalendarz [...] na rok Pański 1977, [oprac. o. Juliusz Wierzbicki OFM Conv.], Kraków [1976], [prowincjałowie Prowincji Zakonu Serafickiego w Polsce], Krakowskie Zakłady Graficzne nr 3, 15 cm., 168 ss.

Treść: jak w poz. 23.

Uwagi: jęz. pol., łac.; uzupełnienie adresu wydawniczego z treści kalendarza.

Oprawa: jak w poz. 19.

Sygn.: KUL-V 18537/1977.

E. - , L. - , Z. -

25. [cz. 1] Kalendarz [...] na rok Pański 1978, [oprac. o. Juliusz Wierzbicki OFM Conv.], Kraków [1977], [b.w.], Drukarnia Narodowa-3, $15 \mathrm{~cm} ., 252$ ss.

Treść: jak w poz. 23.

Uwagi: całość w jęz. pol.; uzupełnienie adresu wydawniczego z treści kalendarza.

Oprawa: papier, twarda.

Sygn.: KUL-V 18537/1978.

E. - , L. - , Z. -

26. [cz. 1] Kalendarz [...] na rok Pański 1979, [oprac. o. Juliusz Wierzbicki OFM Conv.], Kraków [1978], [prowincjałowie Zakonów Franciszkańskich w Polsce], Drukarnia Narodowa-3, 15 cm., 220 ss.

Treść: wprowadzenie, jak w poz. 1, uzupełnienia.

Uwagi: jak w poz. 25.

Oprawa: jak w poz. 19.

Sygn.: KUL-V 18537/1979.

E. - , L. - , Z. -

27. [cz. 1] Kalendarz [...] na rok Pański 1980, [oprac. o. Juliusz Wierzbicki OFM Conv.], Kraków [1979], [prowincjałowie Zakonów Franciszkańskich w Polsce], Drukarnia Narodowa-3, 14 cm., 296 ss.

Treść: wstępne informacje i uwagi, [instrukcje], jak w poz. 1, Różne obrzędy [...].

Uwagi: jak w poz. 25.

Oprawa: jak w poz. 19.

Sygn.: KUL-V 18537/1980.

E. - , L. - , Z. -

28. [cz. 1] Kalendarz [...] na rok Pański 1981, [oprac. o. Juliusz Wierzbicki OFM Conv.], Kraków [1980], [prowincja- 
łowie Zakonów Franciszkańskich w Polsce], Drukarnia Narodowa-3, 14 cm., 204 SS.

Treść: wprowadzenie, jak w poz. 1.

Uwagi: jak w poz. 25.

Oprawa: jak w poz. 19.

Sygn.: KUL-V 18537/1981.

E. - , L. - , Z. -

29. [cz. 1] Kalendarz [...] na rok Pański 1982, [oprac. o. Ambroży Jastrzębski OCap.], Kraków [1981], [prowincjałowie Zakonów Franciszkańskich w Polsce], Drukarnia Narodowa-3, 14 cm., 220 ss.

Treść: jak w poz. 23.

Uwagi: jak w poz. 25

Oprawa: jak w poz. 19.

Sygn.: KUL-V 18537/1982.

E. - , L. - , Z. -

30. [cz. 1] Kalendarz [...] na rok Pański 1983, [oprac. o. Ambroży Jastrzębski OCap.], Kraków [1982], [prowincjałowie Zakonów Franciszkańskich w Polsce], Drukarnia Narodowa-3, 15 cm., 152 ss.

Treść: wprowadzenie, jak w poz. 1, modlitwy.

Proweniencja: Biblioteka Uniwersytetu Marii Curie-Skłodowskiej w Lublinie.

Uwagi: jak w poz. 25.

Oprawa: jak w poz. 19.

Sygn.: KUL-V 18537/1983.

E. - , L. - , Z. -

31. [cz. 1] Kalendarz [...] na rok Pański 1984, [oprac. o. Ambroży Jastrzębski OCap.], Kraków [1983], [prowincjałowie Zakonów Franciszkańskich w Polsce], Drukarnia Narodowa-3, 15 cm., 152 ss.

Treść: jak w poz. 26.

Uwagi: jak w poz. 25.

Oprawa: jak w poz. 19.

Sygn.: KUL-V 18537/1984.

E. -, L. -, Z. -

32. [cz. 1] Kalendarz [...] na rok Pański 1985, [oprac. o. Ambroży Jastrzębski OCap.], Kraków [1984], [prowincjałowie Zakonów Franciszkańskich w Polsce],
Drukarnia Narodowa nr 8, 15 cm., 152 ss.

Treść: [instrukcje], jak w poz. 1, dodatek.

Uwagi: jak w poz. 25.

Oprawa: jak w poz. 19.

Sygn.: KUL-V 18537/1985.

E. -, L. - , Z. -

33. [cz. 1] Kalendarz [...] na rok Pański 1986, [oprac. o. Ambroży Jastrzębski OCap.], Kraków [1985], [prowincjałowie Zakonów Franciszkańskich w Polsce], Drukarnia Narodowa nr 3, 15 cm., 162 [6] ss.

Treść: [instrukcje], jak w poz. 1.

Uwagi: jak w poz. 25.

Oprawa: jak w poz. 19.

Sygn.: KUL-V 18537/1986.

E. - , L. - , Z. -

34. [cz. 1] Kalendarz [...] na rok Pański 1987, [oprac. o. Gracjan Majka OFM Cap.], Kraków [1986], [prowincjałowie Zakonów Franciszkańskich w Polsce], Drukarnia Narodowa nr 3, 15 cm., 200 ss.

Treść: jak w poz. 33.

Uwagi: jak w poz. 25.

Oprawa: jak w poz. 19.

Sygn.: KUL-V 18537/1987.

E. - , L. - , Z. -

35. [cz. 1] Kalendarz [...] na rok Pański 1988, [oprac. o. Emilian Lenart OFM], Kraków [1987], [prowincjałowie Zakonów Franciszkańskich w Polsce], Drukarnia Narodowa nr 3, 15 cm., 216 ss.

Treść: jak w poz. 33.

Uwagi: jak w poz. 25.

Oprawa: jak w poz. 19.

Sygn.: KUL-V 18537/1988.

E. - , L. - , Z. -

36. [cz. 1] Kalendarz [...] na rok Pański 1989, [oprac. o. Emilian Lenart OFM], Kraków [1988], [prowincjałowie Zakonów Franciszkańskich w Polsce], Drukarnia Narodowa nr 3, 15 cm., 238 ss.

Treść: jak w poz. 33.

Uwagi: jak w poz. 25. 
Oprawa: jak w poz. 19.

Sygn.: KUL-V 18537/1989.

E. -, L. -, Z. -

37. [cz. 1] Kalendarz [...] na rok Pański 1990, [oprac. o. Emilian Lenart OFM], Kraków [1989], [prowincjałowie Zakonów Franciszkańskich Polsce], Drukarnia Narodowa Zakł. 3, 15 cm., XXXII, 223 ss.

Treść: jak w poz. 33 .

Uwagi: jak w poz. 25 .

Oprawa: jak w poz. 19.

Sygn.: KUL-V 18537/1990.

E. -, L. - , Z. -

38. [cz. 1] Kalendarz [...] na rok Pański 1991, [oprac. o. Emilian Lenart OFM], Kraków [1990], [prowincjałowie Zakonów Franciszkańskich Polsce], Drukarnia Narodowa Zakł. 3, 15 cm., XXXVI, 216 ss.

Treść: jak w poz. 33.

Uwagi: jak w poz. 25.

Oprawa: jak w poz. 19.

Sygn.: KUL-V 18537/1991a.

E. - , L. - , Z. -

39. [cz. 1] Kalendarz [...] na rok Pański 1992, [oprac. o. Emilian Lenart OFM], Kraków [1991], prowincjałowie Zakonów Franciszkańskich Polsce, Drukarnia Narodowa-3, $15 \mathrm{~cm}$., XII, 208 ss.

Treść: jak w poz. 33.

Uwagi: jak w poz. 25.

Oprawa: jak w poz. 19.

Sygn.: KUL-V 18537/1992.

E. - , L. - , Z. -

40. [cz. 1] Kalendarz [...] na rok Pański 1994, [oprac. o. Emilian Lenart OFM], Kraków [1993], prowincjałowie Zakonów Franciszkańskich Polsce, Wydawnictwo OO. Franciszkanów „Bratni Zew”, 17 cm., $\mathrm{X}, 157$ ss.

Treść: jak w poz. 33.

Uwagi: jak w poz. 25.

Oprawa: jak w poz. 19.

Sygn.: KUL-V 18537/1994.

E. - , L.,- Z. -
41. [cz. 1] Kalendarz [...] na rok Pański 1995, [oprac. o. Emilian Lenart OFM], Kraków [1994], prowincjałowie Zakonów Franciszkańskich Polsce, Wydawnictwo OO. Franciszkanów, 167, X, 153, [3] ss.

Treść: jak w poz. 33.

Uwagi: jak w poz. 25.

Oprawa:. jak w poz. 19, wizerunek św. Antoniego z Dzieciątkiem.

Sygn.: KUL-V 18537/1995.

E. - L. - , Z. -

42. [cz. 1] Kalendarz [...] na rok Pański 1997, [oprac. o. Emilian Lenart OFM], Kraków 1996, prowincjałowie Zakonów Franciszkańskich Polsce, Wydawnictwo OO. Franciszkanów „Bratni Zew”, $17 \mathrm{~cm}$., 214, [31] ss.

Treść: wstęp, jak w poz. 1.

Uwagi: jak w poz. 25.

Oprawa: jak w poz. 19.

Sygn.: KUL-V 18537/1997.

E. -, L. - , Z. -

\section{VIII.5. SCHEMATYZMY \\ FRANCISZKANÓW KONWENTUAL- NYCH PO 1939 ROKU}

1. [cz. 2] Katalog Prowincji Matki Bożej Niepokalanej Zakonu Franciszkanów Konwentualnych w Polsce. Stan z dnia 1 stycznia 1979 r., [oprac. Piotr Anzulewicz OFM Conv.], Niepokalanów 1979, Mała Poligrafia, 21 cm., 234 ss., [2] kk. + fotografie, mapy.

Treść: historia, władze zwierzchnie, skład osobowy poszczególnych domów zakonnych, adresy.

Uwagi: całość w jęz. pol.

Oprawa: papier wydaw., napis podobny, jak na str. tyt.

Sygn.: KUL V-11396/1979.

E. -, L. -, Z. -, W. poz. 307.

2. [cz. 2] Katalog Prowincji Matki Bożej Niepokalanej Zakonu Ojców Franciszkanów w Polsce. Rok Jubileuszowy 19391989, red. Roman Soczewka OFMConv., Warszawa 1989, Mała Poligrafia Ojców 
Franciszkanów w Niepokalanowie, 346, [2] ss. + fotografie, mapy.

Treść: jak w poz. 2.

Uwagi: zmiana tytułu kalendarza w stosunku do poz. 2; całość w jęz. pol.

Oprawa: papier wydaw., półtwarda, napis jak na str. tyt.

Sygn.: KUL V-11396A/1939-89.

E. - , L. - , Z. -

3. [cz. 2] Katalog Franciszkańskiej Prowincji Matki Bożej Niepokalanej w Polsce Zakonu Braci Mniejszych Konwentualnych (Ordinis Fratrum Minorum Conventualium; OFM Conv.) 1939-1999, red. Marian Błaszkiewicz i in., Warszawa 2000, Kuria Prowincjalna Franciszkanów, Wydawnictwo Michalineum, 24 cm., 259, [64] ss., [2] kk. + fotografie, mapy.

Treść: jak w poz. 2.

Uwagi: zmiana tytułu kalendarza w stosunku do poz. 3; całość w jęz. pol.

Oprawa: jak w poz. 2.

Sygn.: KUL V-11396/1939-99.

E. - , L. - , Z. -

4. [cz. 2] Katalog Prowincji św. Maksymiliana Marii Kolbego Ojców Franciszkanów w Polsce [1994], [oprac. Witold Henryk Gral], Gdańsk - Essen 1994, 21 cm., $141 \mathrm{ss}$. + fotografie.

Treść: jak w poz. 2 .

Proweniencja: pieczęć - „Klasztor OO. Franciszkanów Św. Maksymiliana Marii Kolbego w O1szytnie".

Uwagi: zmiana tytułu kalendarza w stosunku do poz. 4; całość w jęz. pol.; kserokopia.

Oprawa: papier, miękka, napis jak na str. tyt.

Sygn.: KUL V-33522/1994.

E. - , L. - , Z. -

\section{JEZUICI}

Towarzystwo Jezusowe (Societatis Jesu - SJ) zostało założone przez św. Ignacego Loyolę w 1534 r., a zatwierdzone przez papieża Pawła III w $1540 \mathrm{r}$.

Do Polski jezuici zostali sprowadzeni w 1564 r. przez bpa warmińskiego S. Hozjusza. Już w 1575 r. powstała prowincja polska (IX.1. Prowincja polska), z której wyodrębniono prowincję litewską (1608). Kolejny podział prowincji polskiej nastąpił w roku 1755 - na prowincję wielkopolską i małopolską. Z kolei wydzielenie prowincji mazowieckiej z dotychczasowej prowincji litewskiej nastąpiło w $1759 \mathrm{r}$. Prowincje te weszły kolejno w skład utworzonej w roku 1756 asystencji polskiej (nadrzędnej jednostki administracyjnej).

Mimo kasaty zakonu w 1773 r., jezuici przetrwali w Cesarstwie Rosyjskim tworząc prowincję białoruską. Wydaleni z Rosji w 1820 r. osiedlili się w m.in. w monarchii austriackiej, gdzie w 1827 r. otrzymali oficjalne pozwolenie władz na prowadzenie swojej działalności w ramach prowincji galicyjskiej - IX.2. (1820-1833). Prowincję galicyjską przemianowano w 1833 r. po przyjęciu placówek w Austrii na prowincję galicyjsko-austriacką (1833-1838), a następnie austriacko-galicyjską (1838-1846) (IX.3). W 1846 r. ponownie podzielono ją na austriacką i galicyjską (IX.4. Prowincja galicyjska). Krótkotrwale, w latach 1848-1852, zakon został skasowany przez rząd austriacki. W 1852 r. jezuici mogli wznowić ponownie działalność w ramach prowincji galicyjskiej, która po odzyskaniu niepodległości przez Rzeczpospolitą, dała podstawę istnienia prowincji polskiej. Prowincja galicyjska została przemianowana w 1918 r. na prowincję polską (IX.5). Tę z kolei w 1926 r. podzielono na małopolską z siedzibą w Krakowie (IX.6) i wielkopolsko-mazowiecką. z siedzibą w Warszawie (IX.7).

Ze względu na wydawanie kalendarzy liturgicznych wspólnych dla wszystkich prowincji, wyodrębniono je w osobnym punkcie (IX.8).

\section{IX.1. PROWINCJA POLSKA (do 1755)}

1. Catalogus personarum \& officiorum Provinciae Polonie Societatis Jesu ex 
anno 1742 in annum 1743, [b.m. 1742], [b.w.d.], [2] kk.

Treść: władze zakonu,zestawienie liczby zakonników, wykaz skrótów, skład osobowy poszczególnych domów zakonnych (niepełny).

Uwagi: zachowane tylko 2 karty.

Oprawa: brak, współoprawny z innymi drukami.

Sygn.: KUL P XVIII.1510

E. -, L. -

\section{IX.2. PROWINCJA GALICYJSKA (1821-1833)}

1. [cz. 2] Catalogi sociorum et officiorum Provinciae Galicianae Societatis Jesu ex annis 1821-1832 nunc primum typis mandate, Cracoviae 1900, sumptibus Patrum Soc. Jesu, E Typographia „Czas” excudebat Josephus Łakociński, 20 cm., 284 SS.

Treść: władze zakonu, skład osobowy poszczególnych domów zakonnych, Vita Functi [...], Defuncti, Index collegiorum [...] ac numerus sociorum, Index alphaeticus, Index locorum [...].

Uwagi: błędna sygn. Powinno być: KUL V3372/1821-32.

Oprawa: brak.

Sygn.: KUL V-3372/1821/23.

E. -, L. -, Z. poz. 55 .

\section{IX.3. PROWINCJA GALICYJSKO- AUSTRIACKA i AUSTRIACKO-GA- LICYJSKA (1833-1846)}

1. [cz. 2] Catalogus sociorum et officiorum Provinciae Galiciae Austriacae Societatis Jesu anno MDCCCXXXIV [1834] ineunte, Leopoli [1833] [b.w.], Typis Josephi Schnayder, $18 \mathrm{~cm} ., 51 \mathrm{ss}$.

Treść: władze zakonu, skład osobowy poszczególnych domów zakonnych, Vita functi Provinciae olim Rossicae (nunc Galiciae Austiracae) ab anno 1820, Defuncti, Index collegiorum [...] ac numerus sociorum, Catalogus sociorum Provinciae olim Rossiacae degentium in variis Provinciis, Index sociorum $[\ldots]$.
Oprawa: papier, miękka.

Sygn.: KUL V-3372/1834.

E. cz. 1, t. I, s.181, L. -, Z. poz. 55.

2. [cz. 2] Catalogus [...] anno ineunte MDCCCXL [1840], Vindobonae 1840, [b.w.], Typis Congragationis Mechitaristicae, $19 \mathrm{~cm}$., 39 ss.

Treść: władze zakonu, skład osobowy poszczególnych domów zakonnych, Ordo regiminis superiorum $[\ldots]$, Vita functi $[\ldots]$, Index domiciliorum [...], Index sociorum [...], Catalogus sociorum Provinciae olim Rossiacae degentium in variis Provinciis.

Proweniencja: napis nieczytelny, fragment: „S. J. A. 1840"'.

Uwagi: tytuł kalendarza, jak w poz. 1 ze zmianą - ,[...] Provinciae Austriaco-Galicianae [...]".

Oprawa: papier.

Sygn.: KUL V-3372/1840.

E. cz. 1, t. I, s. 181, L. -, Z. poz. 55.

\section{IX.4. PROWINCJA GALICYJSKA (1846-1918)}

1. [cz. 2] Catalogus Provinciae Galicianae Societatis Jesu ineunte anno MDCCCXLVII [1847], Leopoli [1846] [b.w.], Typis Petri Piller, 20 cm., 32 ss.

Treść: władze zakonu, skład osobowy poszczególnych domów zakonnych, Ordo regiminis superiorum $[\ldots]$, Vita functi [...], Index collegiorum et domorum [...], Index alphabeticus sociorum [...], Catalogus sociorum Provinciae olim Russiae degentium [...].

\section{Oprawa: papier.}

Sygn.: KUL V-3372/1847.

E. cz. 1, t. I, s. 181, L. - Z. -

2. [cz. 2] Catalogus [...] ineunte anno MDCCCXLVIII [1848], Leopoli [1847], [b.w.], Typis Instituti Stauropigiani, 19 cm., 32 ss.

Treść: jak w poz. 1.

Oprawa: jak w poz. 1.

Sygn.: KUL V-3372/1848.

E. cz. 1, t. I, s. 181, L. -, Z. poz. 55. 
3. [cz. 2] Catalogi disperse Provinciae Galicianae Societatis Jesu ex annis 18491852 nunc primum typis mandati, Cracoviae 1881, sumptibus Patrum Soc. Jesu, E Typographia „Czas”, 20 cm., 86, [1] ss.

Treść: Praefatio, władze zakonu, skład osobowy poszczególnych domów zakonnych, Vita functi, Index locorum $[\ldots]$, Index alphabeticus sociorum [...], Index locorum $[\ldots]$.

Uwagi: zmiana tytułu schematyzmu w stosunku do poz. 1; przypisy.

Oprawa: brak.

Sygn.: KUL V-3372/1849-52.

E. cz. 1, t. I, s. 181, L. -, Z. poz. 55.

4. [cz. 2] Catalogus Provinciae Galicianae Societatis Jesu ineunte anno MDCCCLIII [1853], Leopoli 1853, [b. w.], Typis Michaelis F. Poremba, $20 \mathrm{~cm}$., 22, [1] ss.

Treść: jak w poz. 1, errata.

Uwagi: zmiana tytułu schematyzmu w stosunku do poz. 3 .

Oprawa: papier.

Sygn.: KUL V-3372/1853

E. cz. 1, t. I, s. 181, L. -, Z. poz. 55 .

5. [cz. 2] Catalogus [...] ineunte anno MDCCCLV [1855], Leopoli 1855, in aedebis Instituti Ossoliniani, Typis Michaelis F. Poremba, $19 \mathrm{~cm} ., 22$, [1] ss.

Treść: jak w poz. 4.

Oprawa: papier.

Sygn.: KUL V-3372/1855.

E. cz. 1, t. I, s. 181, L. -, Z. -

6. [cz. 2] Catalogus [...] ineunte anno MDCCCLVIII [1858], Leopoli 1858, [b. w.], Typis Instituti Ossolinscani, $20 \mathrm{~cm} ., 26$ ss.

Treść: jak w poz. 4.

Oprawa: jak w poz. 1.

Sygn.: KUL V-3372/1858.

E. cz. 1, t. I, s. 181, L. -, Z. poz. 55.

7. [cz. 2] Catalogus [...] ineunte anno MDCCCLIX [1859], Leopoli 1859, [b.w.], Typis Instituti Ossolinscani, $21 \mathrm{~cm} ., 26$ ss.
Treść: jak w poz. 4.

Proweniencja: pieczęć owalna z napisem: „,dublet Biblioteki Pozn. Tow. Przyj. Nauk"; pieczęć prostokątna z napisem: „Jan Koźmian”.

Oprawa: jak w poz. 1.

Sygn.: KUL V-3372/1859.

E. cz. 1, t. I, s. 181, L. -, Z. poz. 55 .

8. [cz. 2] Catalogus [...] ineunte anno MDCCCLX [1860], Leopoli 1860, [b.w.], Typis Michalelis F. Poremba, $20 \mathrm{~cm}$., 28 ss.

Treść: jak w poz. 4.

Oprawa: jak w poz. 1.

Sygn.: KUL V-3372/1860.

E. cz. 1, t. I, s.181, L. -, Z. -

9. [cz. 2] Catalogus [...] ineunte anno MDCCCLXII [1862], Leopoli 1862, [b. w.], Typis Michalelis F. Poremba, $22 \mathrm{~cm}$., 30 ss.

Treść: jak w poz. 4.

Oprawa: jak w poz. 1.

Sygn.: KUL V-3372/1860.

E. cz. 1, t. I, s. 181, L. -, Z. poz. 55.

10. Catalogus $[\ldots]$ ineunte anno MDCCCLXVIII [1868], T. Piekarii 1867, [b.w.], Typis Th. Heneczek, 21 cm., 40 ss.

Treść: jak w poz. 4, Prospectus SJ universe, Status $\mathrm{SJ}$ in missionibus [...].

Proweniencja: „Z biblioteki X. Zygmunta Wołek".

Uwagi: błędna sygn. Powinno być: KUL V3372/1868

Oprawa: jak w poz. 1.

Sygn.: KUL V-3372/1867.

E. cz. 1, t. I, s. 181, L. -, Z. -

11. [cz. 2] Catalogus [...] ineunte anno MDCCCLXIX [1869], T. Piekarii 1869, [b.w.], Typis Th. Heneczek, 21 cm., $41 \mathrm{ss}$.

Treść: jak w poz. 4.

Proweniencja: „Z biblioteki X. Zygmunta Wołek".

Oprawa: papier wydaw., napis jak na str. tyt.

Sygn.: KUL V-3372/1869. 
E. cz. 1, t. I, s. 181, L. -, Z. -

12. [cz. 2] Catalogus [...] ineunte anno MDCCCLXX [1870], Cracoviae 1870, [b.w.], Typis Ladislai Jaworski, 20 cm., 41 ss.

Treść: jak w poz. 10.

Oprawa: jak w poz. 11.

Sygn.: KUL V-3372/1870.

E. cz. 1, t. I, s. 181, L. -, Z. poz. 55.

13. [cz. 2] Catalogus [...] ineunte anno MDCCCLXXI [1871], Cracoviae 1871, [b.w.], Typis Ladislai Jaworski, 20 cm., 42 ss., [1] k.

Treść: jak w poz. 10, Adresses, errata.

Oprawa: jak w poz. 1.

Sygn.: KUL V-3372/1871.

E. cz. 1, t. I, s. 181, L. -, Z.-

14. [cz. 2] Catalogus [...] ineunte anno 1872, Cracoviae 1872, [b.w.], Ex Typographia Dicta „Czas”, 19 cm., 43 ss.

Treść: jak w poz. 10, Inscriptiones pro litteris.

Oprawa: brak.

Sygn.: KUL V-3372/1872.

E. cz. 1, t. VI, s. 98, L. -, Z. poz. 55 .

15. [cz. 2] Catalogus ex parte dispersae Provinciae Galicianae Societatis Jesu ineunte anno 1873, Cracoviae 1873, [b.w.], Ex Typographia Dicta „Czas”, 23 cm., 47 ss.

Treść: jak w poz. 10, SJ in Alba Russia [...], adresses.

Uwagi: zmiana tytułu schematyzmu w stosunku do poz. 4.

Oprawa: jak w poz. 11.

Sygn.: KUL V-3372/1873.

E. cz. 1, t. VI, s. 98, L. -,Z. poz. 55.

16. [cz. 2] Catalogus [...] ineunte anno 1874, Cracoviae 1874, [b.w.], Typis Vincentii Kornecki, 21 cm., 35 ss.

Treść: jak w poz. 10, adresses.

Oprawa: jak w poz. 11.

Sygn.: KUL V-3372/1874.

E. cz. 1, t. VI, s. 98, L. -, Z. poz. 55 .
17. [cz. 2] Catalogus Provinciae Galicianae Societatis Jesu ineunte anno 1876, Cracoviae 1876, [sumptibus PP. Soc. Jesu][, Typis Vincentii Kornecki, 20 cm., 41 ss.

Treść: jak w poz. 10, Superscriptio pro epistolis.

Uwagi: zmiana tytułu schematyzmu w stosunku do poz. 15.

Oprawa: jak w poz. 11.

Sygn.: KUL V-3372/1876.

E. cz. 1, t. I, s. 181, L. -, Z. poz. 55.

18. [cz. 2] Catalogus [...] ineunte anno 1877, Cracoviae 1877, [sumptibus PP. Soc. Jesu], Ex Typographia Ephemeridum „Czas”, provisore Josepho Łakociński, 21 cm., 41 ss.

Treść: jak w poz. 15.

Oprawa: jak w poz. 11.

Sygn.: KUL V-3372/1877.

E. cz. 1, t. I, s. 181, L. -, Z. poz. 55.

19. [cz. 2] Catalogus [...] ineunte anno 1878, Cracoviae 1878, [sumptibus PP. Soc. Jesu], Ex Typographia Ephemeridum „Czas”, provisore Josepho Łakociński, 21 cm., 40 ss.

Treść: jak w poz. 15.

Oprawa: jak w poz. 11.

Sygn.: KUL V-3372/1878.

E. cz. 1, t. I, s. 181, L. -, Z. -

20. [cz. 2] Catalogus [...] ineunte anno 1879, Cracoviae 1879, [sumptibus PP. Soc. Jesu], Ex Typographia Ephemeridum „Czas”, provisore Josepho Łakociński, 22 cm., 40 ss.

Treść: jak w poz. 15.

Uwagi: notatki co do treści katalogu ołówkiem. Oprawa: jak w poz. 11.

Sygn.: KUL V-3372/1879.

E. cz. 1, t. I, s. 181, L. -, Z. -

21. [cz. 2] Catalogus [...] ineunte anno 1880, Cracoviae 1880, [sumptibus PP. Soc. Jesu], Ex Typographia Pobudkiewicz, $21 \mathrm{~cm} ., 40 \mathrm{ss}$. 
Treść: jak w poz. 15.

Uwagi: notatki do treści katalogu ołówkiem.

Oprawa: jak w poz. 11.

Sygn.: KUL V-3372/1880.

E. cz. 1, t. I, s. 181, L. -, Z. poz. 55.

22. [cz. 2] Catalogus [...] ineunte anno 1881, Cracoviae 1881, sumptibus PP. Soc. Jesu, E Typographia Ephemeridum „Czas”, provisore Josepho Lakociński, 21 cm., 38 ss., [1] k.

Treść: jak w poz. 15.

Oprawa: jak w poz. 11.

Sygn.: KUL V-3372/1881.

E. cz. 4, t. I, s.218, L. -,Z. poz. 55 .

23. [cz. 2] Catalogus [...] ineunte anno 1882, Cracoviae 1882, sumptibus PP. Soc. Jesu, E Typographia Ephemeridum „Czas”, provisore Josepho Łakociński, 21 cm., 38 ss., [1] k.

Treść: jak w poz. 15.

Oprawa: jak w poz. 11.

Sygn.: KUL V-3372/1882.

E. cz. 4, t. I, s.218, L. -, Z. -

24. [cz. 2] Catalogus [...] ineunte anno $\mathbf{1 8 8 3}$, Cracoviae 1883, sumptibus PP. Soc. Jesu, E Typographia Ephemeridum „Czas” Fr. Kluczycki \& Soc., provisore Josepho Łakociński, $21 \mathrm{~cm}$., 40 ss.

Treść: jak w poz. 15.

Oprawa: jak w poz. 11.

Sygn.: KUL V-3372/1883.

E. cz. 4, t. I, s.218, L. -, Z. poz. 55.

25. [cz. 2] Catalogus [...] ineunte anno 1884, Cracoviae 1884, sumptibus PP. Soc. Jesu, E Typographia Ephemeridum „Czas” Fr. Kluczycki \& Soc., provisore Josepho Łakociński, $22 \mathrm{~cm} ., 40$ ss.

Treść: jak w poz. 15.

Oprawa: jak w poz. 11.

Sygn.: KUL V-3372/1884.

E. cz. 4, t. I, s.218, L. -, Z. -

26. [cz. 2] Catalogus [...] ineunte anno MDCCCLXXXV [1885], Cracoviae
1885, sumptibus PP. Soc. Jesu, E Typographia Ephemeridum „Czas” Fr. Kluczycki \& Soc., provisore Josepho Łakociński, $22 \mathrm{~cm} ., 40 \mathrm{ss}$.

Treść: jak w poz. 15.

Oprawa: jak w poz. 11.

Sygn.: KUL V-3372/1885.

E. cz. 4, t. I, s.218, L. -, Z. -

27. [cz. 2] Catalogus [...] ineunte anno MDCCCLXXXVI [1886], Cracoviae 1886, sumptibus PP. Soc. Jesu, E Typographia Ephemeridum „Czas” Fr. Kluczycki \& Soc., provisore Josepho Łakociński, $21 \mathrm{~cm} ., 48 \mathrm{ss}$.

Treść: jak w poz. 15.

Oprawa: jak w poz. 11.

Sygn.: KUL V-3372/1886.

E. cz. 4, t. I, s.218, L. -, Z. -

28. [cz. 2] Catalogus [...] ineunte anno MDCCCLXXXVII [1887], Cracoviae 1887, sumptibus PP. Soc. Jesu, E Typographia Ephemeridum „Czas” Fr. Kluczycki \& Soc., provisore Josepho Łakociński, $21 \mathrm{~cm} ., 42,[1] \mathrm{ss}$.

Treść: jak w poz. 15.

Oprawa: jak w poz. 11.

Sygn.: KUL V-3372/1887.

E. cz. 4, t. I, s.218, L. -, Z. -

29. [cz. 2] Catalogus [...] ineunte anno MDCCCLXXXVIII [1888], Cracoviae 1888, sumptibus PP. Soc. Jesu, E Typographia Ephemeridum „Czas” Fr. Kluczycki \& Soc., provisore Josepho Łakociński, $21 \mathrm{~cm} ., 44 \mathrm{ss}$.

Treść: jak w poz. 15.

Oprawa: jak w poz. 11.

Sygn.: KUL V-3372/1888.

E. cz. 4 , t. I, s.218, L. -, Z. -

30. [cz. 2] Catalogus [...] ineunte anno MDCCCLXXXVIX [1889], Cracoviae 1889, sumptibus PP. Soc. Jesu, E Typographia Ephemeridum „Czas” Fr. Kluczycki \& Soc., provisore Josepho Łakociński, $21 \mathrm{~cm} ., 46$, [1] ss. 
Treść: jak w poz. 15.

Oprawa: jak w poz. 11.

Sygn.: KUL V-3372/1889.

E. cz. 4 , t. I, s.218, L. -

31. [cz. 2] Catalogus [...] ineunte anno MDCCCXC [1890], Staraviesiae 1890, sumptibus PP. Soc. Jesu, Ex officina typographica Collegii Soc. Jesu, 21 cm., 46 ss., [1] k.

Treść: jak w poz. 15.

Oprawa: jak w poz. 11.

Sygn.: KUL V-3372/1890.

E. cz. 4, t. I, s.218, L. -, Z. poz. 55.

32. [cz. 2] Catalogus [...] ineunte anno MDCCCXCI [1891], Cracovia 1891, Ex Typographia Ephemeridum „Czas” Fr. Kluczycki \& Soc., provisore Josepho Łakociński, $21 \mathrm{~cm} ., 47 \mathrm{ss}$.

Treść: jak w poz. 15.

Oprawa: jak w poz. 11.

Sygn.: KUL V-3372/1891.

E. cz. 4, t. I, s.218, L. -, Z. poz. 55.

33. [cz. 2] Catalogus [...] ineunte anno MDCCCXCII [1892], Staraviesiae 1892, Ex Officina Typographica Collegii Soc. Jesu, $21 \mathrm{~cm}$., 48 ss.

Treść: jak w poz. 15.

Oprawa: jak w poz. 11.

Sygn.: KUL V-3372/1892.

E. cz. 4, t. I, s.218, L. -, Z. poz. 55.

34. [cz. 2] Catalogus [...] ineunte anno MDCCCXCIII [1893], Cracoviae 1893, sumptibus PP. Soc. Jesu, Ex Typographia Ephemeridum „Czas” Fr. Kluczycki \& Soc., provisore Josepho Łakociński, $21 \mathrm{~cm} ., 48 \mathrm{ss}$.

Treść: jak w poz. 15.

Oprawa: jak w poz. 11.

Sygn.: KUL V-3372/1893.

E. cz. 4, t. I, s. 218 , L. s. 407 , Z. poz. 55 .

35. [cz. 2] Catalogus [...] ineunte anno MDCCCXCIV [1894], Cracoviae 1894, sumptibus PP. Soc. Jesu, Ex Typo- graphia Ephemeridum „Czas” Fr. Kluczycki et Soc., provisore Josepho Łakociński, $21 \mathrm{~cm} ., 52$ ss., [1] k. + wklejka.

Treść: jak w poz. 15.

Oprawa: jak w poz. 11.

Sygn.: KUL V-3372/1894.

E. cz. 4, t. I, s.218, L. -, Z. -

36. [cz. 1] Ordo divini officii recitandi sacrique peragedni a PP. Societatis Jesu Provinciae Galicianae anno 1895, Cracoviae 1895, sumptibus PP. Societatis Jesu, E Typoraphia „Czas” Fr. Kluczycki \& Soc., provisore Josepho Łakociński, 19 cm., 42 ss., [1] k.

Treść: zasadniczy zrąb kalendarza, Notanda, Nota.

Uwagi: okładka jest jednocześnie stroną tytułową.

Oprawa: jak w poz. 11.

Sygn.: KUL V-2885/1895.

E. - , L. - , Z. -

37. [cz. 2] Catalogus [...] ineunte anno MDCCCXCV [1895], Cracoviae 1895, sumptibus PP. Soc. Jesu, Ex Typographia Ephemeridum „Czas” Fr. Kluczycki et Soc., provisore Josepho Łakociński, 21 cm., 55 ss.

Treść: jak w poz. 15.

Oprawa: jak w poz. 11.

Sygn.: KUL V-3372/1895.

E. cz. 4, t. I, s.218, L. -, Z. -

38. [cz. 2] Catalogus [...] ineunte anno MDCCCXCVI [1896], Cracoviae 1896, sumptibus PP. Soc. Jesu, Ex Typographia Ephemeridum „Czas” Fr. Kluczycki et Soc., provisore Josepho Łakociński, $21 \mathrm{~cm} ., 55 \mathrm{ss}$.

Treść: jak w poz. 15.

Oprawa: jak w poz. 11.

Sygn.: KUL V-3372/1896.

E. cz. 4, t. I, s.218, L.-

39. [cz. 2] Catalogus [...] ineunte anno MDCCCXCVII [1897], Cracoviae 1897, sumptibus PP. Soc. Jesu, Ex Typographia Ephemeridum „Czas” Fr. Kluczy- 
cki et Soc., provisore Josepho Łakociński, $21 \mathrm{~cm} ., 56 \mathrm{ss}$.

Treść: jak w poz. 15.

Oprawa: półmateriał, twarda, napis złocony: „Catalogus Provinciae Galicianae Societatis Jesu 1897".

Sygn.: KUL V-3372/1897.

E. cz. 4, t. I, s.218, L. -, Z. -

40. [cz. 2] Catalogus [...] ineunte anno MDCCCXCVIII [1898], Cracoviae 1898, sumptibus PP. Soc. Jesu, Ex Typographia Ephemeridum „Czas” Fr. Kluczycki et Soc, provisore Josepho Łakociński, $21 \mathrm{~cm} ., 60 \mathrm{ss}$.

Treść: jak w poz. 15.

Oprawa: jak w poz. 39, napis złocony: „Catalogus Provinciae Galicianae Societatis Jesu 1898”, złocone brzegi.

Sygn.: KUL V-3372/1898.

E. cz. 4, t. I, s.218, L. - Z. -

41. [cz. 2] Catalogus [...] ineunte anno MDCCCXCIX [1899], Cracoviae 1899, sumptibus PP. Soc. Jesu, Ex Typographia Ephemeridum „Czas” Fr. Kluczycki et Soc., provisore Josepho Łakociński, $21 \mathrm{~cm} ., 140 \mathrm{ss}$.

Treść: jak w poz. 15.

Oprawa: jak w poz. 39, napis złocony: „Catalogus Provinciae Galicianae Societatis Jesu 1899”, złocone brzegi.

Sygn.: KUL V-3372/1899.

E. cz. 4, t. I, s.218, L. -, Z.-

42. [cz. 2] Catalogus [...] ineunte anno MCM [1900], Cracovia 1900, sumptibus Patrum Soc. Jesu, E Typographia „Czas” excudebat Josephus Łakociński, sumptibus Patrum Soc. Jesu, 21 cm., 64 ss.

Treść: jak w poz. 15.

Oprawa: jak w poz. 41, napis złocony: „Catalogus Provinciae Galicianae Societatis Jesu 1900”, złocone brzegi.

Sygn.: KUL V-3372/1900.

E. -, L. -, Z. poz. 55 .
43. [cz. 2] Catalogus [...] ineunte anno MCMI [1901], Cracoviae 1901, sumptibus Patrum Soc. Jesu, E Typographia „Czas" excudebat Josephus Łakociński, sumptibus Patrum Soc. Jesu, 21 cm., 63 ss.

Treść: jak w poz. 15.

Oprawa: jak w poz. 39, napis złocony: „Catalogus Provinciae Galicianae Societatis Jesu 1901”.

Sygn.: KUL V-3372/1901.

E. -, L. -, Z. -

44. [cz. 2] Catalogus [...] ineunte anno MCMII [1902], Cracoviae 1902, sumptibus Patum Soc. Jesu, E Typographia „Czas”, $21 \mathrm{~cm} ., 62 \mathrm{ss}$.

Treść: jak w poz. 15.

Oprawa: jak w poz. 39, napis złocony: „Catalogus Provinciae Galicianae Societatis Jesu 1902”.

Sygn.: KUL V-3372/1902.

E. -, L. -, Z. poz. 55 .

44. [cz. 2] Catalogus [...] ineunte anno MCMIII [1903], Cracoviae 1903, sumptibus Patrum Soc. Jesu, E Typographia „Czas”, sumptibus Patrum Soc. Jesu, 21 cm., 60 ss.

Treść: jak w poz. 15.

Oprawa: jak w poz. 11, brak okładki z tyłu.

Sygn.: KUL V-3372/1903.

E. - , L. - , Z. -

46. [cz. 2] Catalogus [...] ineunte anno MCMIV [1904], Cracovia 1904, sumptibus Patrum Soc. Jesu, E Typographia „Czas”, sumptibus Patrum Soc. Jesu, 21 cm., $60 \mathrm{ss}$.

Treść: jak w poz. 15.

Oprawa: jak w poz. 39, napis złocony: „Catalogus Provinciae Galicianae Societatis Jesu 1904”, złocone brzegi.

Sygn.: KUL V-3372/1904.

E. - , L. - , Z. -

47. [cz. 2] Catalogus [...] ineunte anno MCMV [1905], Cracoviae 1905, sumptibus Patrum Soc. Jesu, E Typographia „Czas”, sumptibus Patrum Soc. Jesu, 21 cm., 63 ss. 
Treść: jak w poz. 15.

Oprawa: jak w poz. 39, napis złocony: „Catalogus Provinciae Galicianae Societatis Jesu 1905”, złocone brzegi.

Sygn.: KUL V-3372/1905.

E. - , L. - , Z. -

48. [cz. 2] Catalogus [...] ineunte anno MCMVI [1906], Cracoviae 1906, sumptibus Patrum Soc. Jesu, E Typographia „Czas”, $21 \mathrm{~cm} ., 67 \mathrm{ss}$.

Treść: jak w poz. 15, bez Superscriptio pro epistolis.

Oprawa: jak w poz. 39, napis złocony: „Catalogus Provinciae Galicianae Societatis Jesu 1906”, złocone brzegi.

Sygn.: KUL V-3372/1906.

E. - , L. - , Z. -

49. [cz. 2] Catalogus [...] ineunte anno MCMVII [1907], Cracoviae 1907, E Typographia „Czas”, sumptibus Patrum Soc. Jesu, 31, 66 ss.

Treść: jak w poz. 48.

Oprawa: jak w poz. 39, napis złocony: „Catalogus Provinciae Galicianae Societatis Jesu 1907”, złocone brzegi.

Sygn.: KUL V-3372/1907.

E. - , L. - , Z. -

50. [cz. 2] Catalogus [...] ineunte anno MCMVIII [1908], Cracoviae 1908, E Typographia „Czas”, sumptibus Patrum Soc. Jesu, $21 \mathrm{~cm}$., 66 ss.

Treść: jak w poz. 48.

Oprawa: jak w poz. 39, napis złocony: „Catalogus Provinciae Galicianae Societatis Jesu 1908”, złocone brzegi.

Sygn.: KUL V-3372/1908.

E. -, L. - , Z. -

51. [cz. 2] Catalogus [...] ineunte anno MCMVIX [1909], Cracoviae 1909, E Typographia „Czas”, sumptibus Patrum Soc. Jesu, 20 cm., 69 ss., [1] k.

Treść: jak w poz. 48.

Proweniencja: pieczęci:1. „Бібліотека гр. кат. капітули в Перемишлі ч ...”; 2. Бібліотека
Епископа Перемыского Дра. Юліана Пелеа Чo.........".

Oprawa: jak w poz. 39, napis złocony: „Catalogus Provinciae Galicianae Societatis Jesu 1909”, złocone brzegi.

Sygn.: KUL V-3372/1909.

E. - , L. - , Z. -

52. [cz. 2] Catalogus [...] ex anno 1909 in annum 1910, Cracoviae 1909, [sumptibus Patrum Soc. Jesu], E Typographia „Czas”, 21 cm., 69 ss., [1] k.

Treść: jak w poz. 48.

Uwagi: zmiana tytułu schematyzmu; w adresie wydaw. napis: „mense Octobri 1909”.

Oprawa: jak w poz. 11.

Sygn.: KUL V-3372/1909/1910.

E. -, L. -, Z. -

53. [cz. 2] Catalogus [...] ex anno 1910 in annum 1911, Cracoviae 1910, [sumptibus Patrum Soc. Jesu], E Typographia „Czas”, $21 \mathrm{~cm} ., 73$ ss., [1] k.

Treść: jak w poz. 48.

Proweniencja: jak w poz. 51.

Uwagi: w adresie wydaw. napis: „mense Novembri 1910".

Oprawa: papier wydaw., półtwarda, napis jak na str. tyt., złocony brzeg okładki.

Sygn.: KUL V-3372/1910/1911.

E. -, L. -, Z. poz. 55 .

54. [cz. 2] Catalogus [...] ex anno 1911 in annum 1912, Cracoviae 1911, [sumptibus Patrum Soc. Jesu], E Typographia „Czas”, 22 cm., 73 ss., [1] k.

Treść: jak w poz. 48.

Proweniencja: jak w poz. 51.

Uwagi: w adresie wydaw. napis: „mense Novembri 1911".

Oprawa: jak w poz. 39, napis: „Catalogus Provinciae Galicianae Societatis Jesu 1911-12”, złocony brzeg okładki, tytuł, złocone kartki.

Sygn.: KUL V-3372/1911/1912.

E.,- L. - , Z. -

55. [cz. 2] Catalogus [...] ex anno 1912 in annum 1913, Cracoviae 1912, 
[sumptibus Patrum Soc. Jesu], E Typographia „Czas”, 22 cm., 74 ss., [2] kk.

Treść: jak w poz. 48.

Proweniencja: jak w poz. 51.

Uwagi: w adresie wydaw. napis: „mense Octobri 1912".

Oprawa: jak w poz.39, napis: „Catalogus Provinciae Galicianae Societatis Jesu 1912-13”, złocony brzeg okładki, tytuł, złocone kartki.

Sygn.: KUL V-3372/1912/1913.

E. -, L. - Z. -

56. [cz. 2] Catalogus [...] ex anno 1913 in annum 1914, Cracoviae 1913, [sumptibus Patrum Soc. Jesu], E Typographia „Czas”, 21 cm., 77 ss., [1] k.

Treść: jak w poz.48.

Uwagi: w adresie wydaw. napis: „mense novembri 1913",

Oprawa: jak w poz. 11.

Sygn.: KUL V-3372/1913/1914.

E. - , L. - , Z. -

57. [cz. 2] Catalogus [...] anno 1916, Cracoviae 1916, [sumptibus Patrum Soc. Jesu], E Typographia „Czas”, 21 cm., 78 ss., [1] k.

Treść: jak w poz.48.

Oprawa:. jak w poz. 11, spis treści na okładce z tyłu.

Sygn.: KUL V-3372/1916.

E. - , L. - , Z. -

58. [cz. 2] Catalogus [...] ex anno 1916 in annum 1917, Cracoviae 1916, [sumptibus Patrum Soc. Jesu], E Typographia „Czas”, 21 cm., 77 ss., [1] k.

Treść: jak w poz. 48.

Oprawa: jak w poz. 57.

Sygn.: KUL V-3372/1916/1917.

E. - , L. - , Z. -

\section{IX.5. PROWINCJA POLSKA (1918-1926)}

1. [cz. 2] Catalogus Provinaciae Poloniae Societatis Iesu ex anno 1918 in annum
1919, Tarnoviae 1918, sumptibus Patrum Soc. Jesu, Typis Sigismundi Jeleń, $20 \mathrm{~cm}$., 83 ss.

Treść: władze zakonu, skład osobowy poszczególnych domów zakonnych, Prospectus Societatis Iesu Universae, Index alphabeticus sociorum, Prospectus Missionum Societatis Iesu, Inscriptiones litterarum.

Uwagi: Editioni huius Catalogi finis impsitus est die 14 Novembris 1918

Oprawa: papier wydaw., miękka.

Sygn.: KUL V-3372/1919.

E. - , L. - , Z. poz. 55 .

2. [cz. 2] Catalogus Provinaciae Poloniae Societatis Iesu ineunte anno 1920, Tarnoviae 1918, sumptibus Patrum Soc. Jesu, Typis Sigismundi Jeleń, 20 cm., 69 ss. + wklejka.

Treść: jak w poz. 1

Uwagi: zmiana tytułu schematyzmu w stosunku do poz. 1.

Oprawa: jak w poz. 1.

Sygn.: KUL V-3372/1920.

E. - , L. - , Z. -

3. [cz. 2] Catalogus [...] ineunte anno 1921, Cracoviae 1921, sumptibus Patrum Soc. Jesu, Typis L. Poturalski, 21 cm., 68 ss.

Treść: jak w poz. 1.

Oprawa: jak w poz. 1.

Sygn.: KUL V-3372/1921.

E. - L. - , Z. -

4. [cz. 2] Catalogus [...] ineunte anno 1922, Cracoviae 1922, sumptibus Patrum Soc. Jesu, E Typographia periodici „Przegląd Powszechny”, 21 cm., 67, [1] ss.

Treść: jak w poz. 1.

Uwagi: Impressus die 18 nov. 1921.

Oprawa: jak w poz. 1.

Sygn.: KUL V-3372/1922.

E. -, L. s. 408, Z. poz. 55.

5. [cz. 1] Ordo divini officii presolvendi sacrorumque faciendorum in Provincia Poloniae Societatis Jesu anno 1923, 
[auctore P. Iosepho Antoniewicz S. I., Chełm Lubelski], Premisliae [1922], [sumptibus Ordinis], Typis Iosephi Styfi, $15 \mathrm{~cm} ., 80 \mathrm{ss}$.

Treść: zasadniczy zrąb kalendarza, Appendix, Tabella mutationum lunae.

Uwagi: zmiana tytułu schematyzmu w stosunku do poz. 2; okładka jest jednocześnie str. tyt., adres wydaw. Uzupełniony z treści kalendarza.

Oprawa: papier wydaw., miękka, tytuł.

Sygn.: KUL V-2885/1923.

E. -, L. -, Z. -

6. [cz. 2] Catalogus [...] ex anno 1922 in annum 1923, Cracoviae 1922, sumptibus Patrum Soc. Jesu, E Typographia periodici „Przegląd Powszechny”, 21 cm., 79, [1] ss.

Treść: jak w poz. 1.

Uwagi: zmiana tytułu schematyzmu; Impressus die 10 Oct. 1922

Oprawa: jak w poz. 1.

Sygn.: KUL V-3372/1922/23.

E. -, L. s. 408 , Z. -

7. [cz. 2] Catalogus [...] ex anno 1923 in annum 1924, Cracoviae 1923, sumptibus Patrum Soc. Jesu, E Typographia periodici „Przegląd Powszechny”, 21 cm., 80 ss.

Treść: jak w poz. 1.

Uwagi: Impressus die 25 Oct. 1923.

Oprawa: jak w poz. 1.

Sygn.: KUL V-3372/1923/24.

E. -, L. s. 408 , Z. -

8. [cz. 2] Catalogus [...] ex anno 1924 in annum 1925, Cracoviae 1924, sumptibus Patrum Soc. Jesu, E Typographia periodici „Przegląd Powszechny”, 21 cm., 84 ss.

Treść: jak w poz. 1.

Oprawa: jak w poz. 1.

Sygn.: KUL V-3372/1924/25.

E. -, L. s. 408 , Z. -

9. Sygn.: KUL V-3372/1925/26 (schematyzm) - brak.

\section{6. PROWINCJA MALOPOLSKA (1926-)}

1. [cz. 2] Catalogus Provinciae Poloniae Minoris Societatis Iesu anni 1927, Cracoviae 1926, [b.w.], E Typographia periodici „Przegląd Powszechny”, 21 cm., 91 ss.

Treść: władze, skład osobowy poszczególnych domów zakonnych, Index collegiorum et domorum ac numerus sociorum, Curia Societatis Iesu, Prospectus Societatis Iesu universae, Prospectus missionum Societatis Iesu, Index alphabeticus sociorum, Inscriptiones epistolarum.

Uwagi: wizytówka ks. Władysława Jankiewicza, prowincjała oo. Jezuitów w Małopolsce, Impressus die 17 Decembris 1926.

Oprawa: papier wydaw., miękka.

Sygn.: KUL V-3374/1927.

E. -, L. s. 410 , Z. poz. 56 .

2. [cz. 2] Catalogus [...] anni 1928, Cracoviae 1928, [b.w.], E Typographia periodici „Przegląd Powszechny”, 21 cm., 94 ss. + wklejka.

Treść: jak w poz. 1.

Uwagi: notatki na okładce tylnej ołówkiem, Impressus die 17 ianuarii 1928.

Oprawa: papier wydaw., miękka - oryginalna, tektura, twarda -wtórna

Sygn.: KUL V-3374/1928.

E. -, L. s. 410, Z. poz. 56.

3. [cz. 2] Catalogus [...] anni 1929, Cracoviae 1928, [b.w.], E Typographia periodici „Przegląd Powszechny”, 21 cm., 96 sS.

Treść: jak w poz. 1.

Uwagi: Impressus die 16 novembris 1928.

Oprawa: tektura, twarda, półpłótno, zdobiona, napis: „Catalogus Provinciae Poloniae Minoris Soc. Iesu 1929”, w prawym górnym rogu inicjał „D.G.”

Sygn.: KUL V-3374/1929.

E. -, L. -, Z. poz. 56 .

4. [cz. 2] Catalogus [...] anni 1930, Cracoviae 1929, [b.w.], E Typographia periodici „Przegląd Powszechny”, $20 \mathrm{~cm}$., 104 ss. 
Treść: jak w poz. 1.

Uwagi: Impressus die 16 novembris 1929.

Oprawa: tektura, twarda, półpłótno, zdobiona, napis: „Catalogus Provinciae Poloniae Minoris Soc. Iesu 1930”, w prawym górnym rogu inicjał „D.G.”

Sygn.: KUL V-3374/1930.

E. -, L. -, Z. poz. 56 .

5. [cz. 2] Catalogus [...] anni 1931, Cracoviae 1930, [b.w.], E Typographia periodici „Przegląd Powszechny”, $21 \mathrm{~cm}$., 105 ss.

Treść: jak w poz. 1.

Uwagi: Impressus die 29 novembris 1930.

Oprawa: jak w poz. 1.

Sygn.: KUL V-3374/1931.

E. -, L. - Z. -

6. [cz. 2] Catalogus [...] anni 1932, Cracoviae 1931, [b.w.], E Typographia periodici „Przegląd Powszechny”, $21 \mathrm{~cm}$., 106 ss.

Treść: jak w poz. 1.

Uwagi: Impressus die 15 Decembris 1931.

Oprawa: jak w poz. 1.

Sygn.: KUL V-3374/1932.

E. -, L. s. 410, Z. poz. 56.

7. [cz. 2] Catalogus [...] anni 1933, Cracoviae 1932, [b.w.], E Typographia periodici „Przegląd Powszechny”, $21 \mathrm{~cm}$., 107 ss.

Treść: jak w poz. 1.

Uwagi: Impressus die 22 novembris 1932.

Oprawa: jak w poz. 1.

Sygn.: KUL V-3374/1933.

E. - , L. - , Z. -

8. [cz. 2] Catalogus [...] anni 1934, Cracoviae 1933, [b.w.], E Typographia periodici „Przegląd Powszechny”, $21 \mathrm{~cm}$., 105 ss.

Treść: jak w poz. 1.

Uwagi: Impressus die 23 novembris 1933.

Oprawa: tektura, półpłótno, twarda, zdobiona, napis: „Catalogus Provinciae Poloniae Minoris Societatis Iesu 1934”.

Sygn.: KUL V-3374/1934.
E. -, L. s. 410, Z. poz. 56 .

9. [cz. 2] Catalogus [...] anni 1935, Cracoviae 1934, [b.w.], E Typographia periodici „Przegląd Powszechny”, $21 \mathrm{~cm}$., 115 ss.

Treść: jak w poz. 1.

Uwagi: Impressus die 28 nov. 1934.

Oprawa: jak w poz. 1.

Sygn.: KUL V-3374/1935.

E. -, L. -, Z. poz. 56 .

10. [cz. 2] Catalogus [...] ineunte anno MCMXXXVI [1936], Cracoviae 1936, [b.w.], E Typographia periodici „Przegląd Powszechny", $21 \mathrm{~cm}$., 105 ss.

Treść: jak w poz. 1.

Uwagi: Impressus die 15 ian. 1936.

Oprawa: jak w poz. 1.

Sygn.: KUL V-3374/1936.

E. - , L. - , Z. -

11. [cz. 2] Catalogus [...] ineunte anno 1937, Cracoviae 1937, [b.w.], E Typographia „Apostolatus Orationis”, $21 \mathrm{~cm}$., 109 ss. + wklejka.

Treść: jak w poz. 1.

Uwagi: Typis editus 2 dec. 1936.

Oprawa: jak w poz. 1.

Sygn.: KUL V-3374/1937.

E. -, L. s. 410, Z. poz. 56.

12. [cz. 2] Catalogus [...] ineunte anno 1938, Cracoviae 1938, [b.w.], E Typographia editionum „Apostolatus Orationis", $21 \mathrm{~cm} ., 104$ ss.

Treść: jak w poz. 1.

Uwagi: Typis editus 7 dec. 1937.

Oprawa: jak w poz. 1.

Sygn.: KUL V-3374/1938.

E. - , L. - , Z. -

13. [cz. 2] Catalogus [...] ineunte anno 1939, Cracoviae 1939, [b.w.], E Typographia editionum ,Apostolatus Orationis", 21 cm., 109 ss. + wklejka.

Treść: jak w poz. 1.

Uwagi: Impressus die 22 dec. 1938. 
Oprawa: papier wydaw., miękka - oryginalna, tektura, twarda - wtórna

Sygn.: KUL V-3374/1939.

E. -, L. -, Z. poz. 56 .

14. [cz. 2] Catalogus [...] anni 1946, Romae 1947, [b.w.], Ex Typographia Pont. Univ. Gregorianae, 21 cm., 96 ss.

Treść: jak w poz. 1.

Uwagi: Impressus die 25 Martii 1947.

Oprawa: papier wydaw., miękka - oryginalna, tektura, twarda - wtórna.

Sygn.: KUL V-3374/1946.

E. - , L. - , Z. -

15. [cz. 2] Catalogus [...] ineunte an. 1947, Cracoviae 1947, [b.w.], Colleium Maximum SS. Cordis, 21 cm., 44 ss.

Treść: władze zwierzchnie, skład osobowy domów zakonnych, Index domorum et numerus sociorum. Inscriptiones epistolarum.

Uwagi: pisany maszynowo, na okładce pieczęć z napisem: „Wydawnictwo Apostolstwa Modlitwy Kraków ul. Kopernika 26"; Impressus die 2 april 1947.

Oprawa: papier, miękka, napis jak na str. tyt.

Sygn.: KUL V-3374/1947.

E. - , L. - , Z. -

16. [cz. 2] Catalogus [...] ineunte anno MCMXLIX [1949], Cracoviae 1949, [b.w.d.], $20 \mathrm{~cm} ., 65$ ss. + wklejka.

Treść: jak w poz. 1.

Uwagi: pisany maszynowo, mapa; Impressus die 5 ian. 1949.

Oprawa: jak w poz. 15.

Sygn.: KUL V-3374/1949.

E. -, L. - Z. -

17. [cz. 2] Catalogus [...] ineunte anno MCML [1950], Cracoviae 1950, [b.w.d.], 21 cm., 64 ss. + wklejka.

Treść: jak w poz. 1.

Uwagi: pisany maszynowo, mapa; Impressus die 4 ian. 1950.

Oprawa: jak w poz. 15.

Sygn.: KUL V-3374/1950.

E. - , L.,- Z. -
18. [cz. 2] Catalogus [...] ineunte anno 1952, Cracoviae [1951], [b.w.d.], 21 cm., 72 ss.

Treść: jak w poz. 1 .

Uwagi: pisany maszynowo, mapa; Impressus die 25 novembr. 1951

Oprawa: jak w poz. 15.

Sygn.: KUL V-3374/1952.

E. - , L. - Z. -

19. [cz. 2] Catalogus [...] ineunte anno 1957, Cracoviae [1956], [b.w.d.], 19 cm., 78 ss.

Treść: jak w poz. 1.

Uwagi: pisany maszynowo, mapa; Impressus die 15 ian. 1957.

Oprawa: papier wydaw., miękka, napis jak na str. tyt.; tektura, twarda - wtórna.

Sygn.: KUL V-3374/1957.

E. - , L. - Z. -

20. Sygn.: KUL V-3374/1958 (schematyzm) - brak.

\section{IX.7. PROWINCJA WIELKOPOLSKO - MAZOWIECKA (1926-)}

1. [cz. 2] Catalogus Provinaciae Poloniae Maioris et Mazoviae Societatis Iesu ex anno 1926 in annum 1927, Cracoviae 1926, [b.w.], E Typographia periodici „Przegląd Powszechny", 21 cm., 70 ss. + wklejka.

Treść: władze zwierzchnie, skład osobowy poszczególnych domów zakonnych, Prospectus Societatis Iesu universae, Prospectus missionum Societatis Iesu ineunte anno 1926, Index alphabeticus sociorum, Inscriptiones epistolarum.

Proweniencja: „Br. Eugeniusz Żeleźniak T. J.” (pieczęć).

Uwagi: Typis editus die 10 Dec. 1926.

Oprawa: papier wydaw., miękka.

Sygn.: KUL V-3373/1926/27.

E. -, L. -, Z. poz. 57.

2. [cz. 2] Catalogus [...] ex anno 1927 in annum 1928, Cracoviae 1927, [b.w.], E Typographia periodici „Przegląd Powszechny", $20 \mathrm{~cm}$., 68 ss. 
Treść: jak w poz. 1.

Uwagi: Typis editus die 20 otc. 1927.

Oprawa: jak w poz. 1.

Sygn.: KUL V-3373/1928.

E. -, L. -, Z. poz. 57.

3. [cz. 2] Catalogus [...] anni 1929, Cracoviae 1928, [b.w.], E Typographia periodici „Przegląd Powszechny”, 20 cm., 70 ss. + wklejka.

Treść: jak w poz. 1 .

Uwagi: Typis editus 6 nov. 1928

Oprawa: jak w poz. 1.

Sygn.: KUL V-3373/1929.

E. -, L. -, Z. poz. 57 .

4. [cz. 2] Catalogus [...] anni 1931, Cracoviae 1930, [b.w.], E Typographia periodici „Przegląd Powszechny”, 21 cm., 84 ss.

Treść: jak w poz. 1

Uwagi: Typis editus 21 nov. 1930.

Oprawa: papier wydaw., miękka - oryginalna, tektura, twarda - wtórna.

Sygn.: KUL V-3373/1931.

E. -, L. -, Z. poz. 57.

5. [cz. 2] Catalogus [...] anni 1932, Cracoviae 1931, [b.w.], E Typographia periodici „Przegląd Powszechny”, 21 cm., 86 ss. + wklejka.

Treść: jak w poz. 1

Proweniencja: napis atramentem na okładce: „fr. Gatkowski”.

Uwagi: Typis editus 7 dec. 1931.

Oprawa: jak w poz. 1.

Sygn.: KUL V-3373/1932.

E. -, L. -, Z. poz. 57 .

6. [cz. 2] Catalogus [...] anni 1933, Cracoviae 1932, [b.w.], E Typographia periodici „Przegląd Powszechny”, $21 \mathrm{~cm} ., 88$ ss.

Treść: jak w poz. 1

Uwagi: Typis editus 1 dec. 1932.

Oprawa: jak w poz. 1.

Sygn.: KUL V-3373/1933.

E. -, L. - Z. -
7. [cz. 2] Catalogus [...] anni 1934, Cracoviae 1933, [b.w.], E Typographia periodici „Przegląd Powszechny”, 21 cm., 89 SS.

Treść: jak w poz. 1 .

Uwagi: Typis editus 15 nov. 1933.

Oprawa: jak w poz. 1.

Sygn.: KUL V-3373/1933.

E. -, L. -, Z. -

8. [cz. 2] Catalogus [...] anni 1935, Cracoviae 1934, [b.w.], E Typographia periodici „Przegląd Powszechny”, 21 cm., 88 SS.

Treść: jak w poz. 1.

Uwagi: Typis editus 30 nov. 1934.

Oprawa: jak w poz. 1.

Sygn.: KUL V-3373/1935.

E. -, L. - Z. -

9. [cz. 2] Catalogus [...] anni 1936, Cracoviae 1935, [b.w.], E Typographia periodici „Przegląd Powszechny”, 21 cm., 95 ss.

Treść: jak w poz. 1

Uwagi: Typis editus 18 dec. 1935.

Oprawa: jak w poz. 1.

Sygn.: KUL V-3373/1936.

E. - , L. - , Z. -

10. [cz. 2] Catalogus [...] anni 1937, Varsaviae 1936, [b.w.], E Typographia „Wydawnictwo Księży Jezuitów”, 21 cm., 99 ss.

Treść: jak w poz. 1.

Proweniencja: na wewnętrznej okładce ex libris: „Stanislai Oczkowski”.

Uwagi: dołączony list pisany maszynowo z własnoręcznym podpisem ks. Stanisława Sopucha T.J., który potwierdza przesłanie schematyzmu TJ oraz zawiera prośbę o przesłanie schematyzmu diecezji lubelskiej; Typis editus 13 novembris.

Oprawa: jak w poz. 1.

Sygn.: KUL V-3373/1937.

E. -, L. -, Z. poz. 57.

11. [cz. 2] Catalogus [...] anni 1938 , Varsaviae 1937, [b.w.], E Typographia 
„Wydawnictwo Księży Jezuitów”, 21 cm., 101 ss. + wklejka.

Treść: jak w poz. 1 .

Uwagi: Typis editus 20 novembris 1937.

Oprawa: jak w poz. 1.

Sygn.: KUL V-3373/1938.

E. -, L. -, Z. poz. 57.

12. [cz. 2] Catalogus [...] anni 1939, Varsaviae 1939, [b.w.], E Typographia „Wydawnictwo Księży Jezuitów”, 21 cm., 106 ss., + wklejka.

Treść: jak w poz. 1.

Uwagi: Typis editus 10 ianuarii 1939.

Oprawa: jak w poz. 1.

Sygn.: KUL V-3373/1939.

E. - , L. - , Z. -

13. [cz. 2] Catalogus [...] ineunte anno 1956 (Status die 31 dec. 1955), Varsaviae [1955], [b.w.d.], 19 cm., 76 ss. + wklejka.

Treść: władze zwierzchnie, skład osobowy poszczególnych domów zakonnych, Index domiciliorum ac numerus sociorum, Index alphabeticus sociorum, Inscriptiones epistolarum [...].

Uwagi: maszynopis; Impressus die 21 feb. 1957, mapa.

Oprawa: papier wydaw., miękka - oryginalna, tektura, twarda - wtórna.

Sygn.: KUL V-3373/1956.

E. -, L. -, Z. -

14. [cz. 2] Catalogus [...] ineunte anno 1957 (Status die 31 dec. 1956), Varsaviae [1956], [b.w.d.], 19 cm., 75 ss. + wklejka.

Treść: jak w poz. 13.

Uwagi: maszynopis; Impressus die 28 iun 1957, mapa

Oprawa: papier wydaw., miękka - oryginalna, tektura, twarda - wtórna.

Sygn.: KUL V-3373/1957.

E. - , L. - , Z. -

15. [cz. 2] Catalogus Provinciarum Poloniae Societatis Iesu 1987, [b.m. 1986], [b.w.d.], $20 \mathrm{~cm} ., 104$ ss.
Treść: władze zwierzchnie, skład osobowy poszczególnych domów zakonnych, Index alphabeticus sociorum.

Uwagi: maszynopis, mapy, Impressus die 28 nov. 1986

Oprawa: papier wydaw., miękka.

Sygn.: KUL V-3373/1987.

E. - , L. - , Z. -

\section{IX.8. JEZUICI. KALENDARZE PRO- WINCJI NA TERENIE POLSKI}

1. [cz. 1] Ordo divini officii persolvendi sacrorumque faciendorum in Provinciis Poloniae Societatis Jesu anno 1937, (auctore Josepho Antoniewicz S.J.), Cracoviae [1936], [sumptibus Ordinis], Drukarnia Apostolstwa Modlitwy, 15 cm., 128 ss.

Treść: Praenotanda, zasadniczy zrąb kalendarza.

Uwagi: brak str. tyt., jęz. pol., łac.

Oprawa: papier, twarda, tytuł.

Sygn.: KUL-V 2885/1937.

E. -, L. -, Z. -

2. [cz. 1] Ordo [...] anno 1942 servandus, Cracoviae 1942, Typis Drukarnia Udziałowa, 15 cm., 36 ss., [1] k.

Treść: zasadniczy zrąb kalendarza, Appendix.

Oprawa: jak w poz. 1.

Sygn.: KUL-V 2885/1942.

E. - , L. - , Z. -

3. [cz. 1] Ordo [...] anno 1945, (auctore Josepho Antoniewicz S.J.), Miejsce Piastowe [1944], [sumptibus Ordinis], Typis Societatis S. Michaelis Archang., 15 cm., 127 ss.

Treść: jak w poz. 1.

Uwagi: brak str. tyt., jęz. pol., łac.

Oprawa: jak w poz. 1.

Sygn.: KUL-V 2885/1945.

E. - , L. - , Z. -

4. [cz. 1] Ordo [...] anno 1946, (auctore Josepho Antoniewicz S.J.), Katowice [1945], [sumptibus Ordinis], 
Księgarnia i Drukarnia Katolicka, 15 cm., 80 ss.

Treść: jak w poz. 1.

Uwagi: jak w poz. 3 .

Oprawa: jak w poz. 1.

Sygn.: KUL-V 2885/1946.

E. -, L. -, Z. -

5. [cz. 1] Ordo [...] anno 1949, (auctore Josepho Antoniewicz S.J.), [sumptibus Ordinis], Cracoviae [1948], Drukarnia Udziałowa, $15 \mathrm{~cm} ., 104,8$ ss.

Treść: jak w poz. 1, Lectiones contractae.

Uwagi: jak w poz. 3 .

Oprawa: jak w poz. 1.

Sygn.: KUL-V 2885/1949.

E. - , L. - , Z. -

6. [cz. 1] Ordo [...] anno 1950, (auctore Josepho Antoniewicz S.J.), Cracoviae [1949], Wydawnictwo Apostolstwa Modlitwy Księża Jezuici, Drukarnia Związkowa, $15 \mathrm{~cm} ., 108$ ss.

Treść: jak w poz. 5.

Uwagi: jak w poz. 3 .

Oprawa: jak w poz. 1.

Sygn.: KUL-V 2885/1950.

E. - , L. - , Z. -

7. [cz. 1] Ordo [...] anno 1956, Kraków [1955], Wydawnictwo Apostolstwa Modlitwy, Krakowskie Zakłady Graficzne Zakład 7, 15 cm., 115 ss., [1] k. dodatek.

Treść: [instrukcje], zasadniczy zrąb kalendarza,

Uwagi: jęz. pol., łac., kartki do wyrywania.

Oprawa: papier wydaw., twarda, napis jak na str. tyt.

Sygn.: KUL-V 2885/1956.

E. - , L. - , Z. -

8. [cz. 1] Ordo [...] anno 1957, Kraków [1956], Wydawnictwo Apostolstwa Modlitwy, Krakowskie Zakłady Graficzne Zakład 7, 15 cm., 144 ss.

Treść: Notanda, zasadniczy zrąb kalendarza.

Proweniencja: Biblioteka Uniwersytetu Marii Curie-Skłodowskiej w Lublinie.
Uwagi: kartki do wyrywania, Schemata pro recitatione Breviarii - wkładka.

Oprawa: jak w poz. 7.

Sygn.: KUL-V 2885/1957.

E. -, L. - , Z. -

9. [cz. 1] Ordo [...] anno 1958, Kraków [1957], Wydawnictwo Apostolstwa Modlitwy, Krakowskie Zakłady Graficzne Zakład 7, 15 cm., 183 ss.

Treść: jak w poz. 8, Dodatki do oficjów brewiarzowych

Proweniencja: jak w poz. 8 .

Uwagi: kartki oraz rogi kart do wyrywania.

Oprawa: jak w poz. 7.

Sygn.: KUL-V 2885/1958.

E. - , L. - , Z. -

10. [cz. 1] Ordo [...] anno 1959, Kraków [1958], Wydawnictwo Apostolstwa Modlitwy, Krakowskie Zakłady Graficzne Zakład 7, 15 cm., 146 ss

Treść: Notanda, zasadniczy zrąb kalendarza, Odpusty.

Proweniencja: jak w poz. 8 .

Uwagi: karty do wyrywania, Schemata pro recitatione Breviarii - wkładka.

Oprawa: jak w poz. 7.

Sygn.: KUL-V 2885/1959.

E. - , L. - , Z. -

11. [cz. 1] Ordo [...] pro A.D. 1963, [auctore Josepho Żukowicz], Kraków [1962], Wydawnictwo Apostolstwa Modlitwy, Drukarnia Związkowa, 15 cm., 267 ss., [2] kk.

Treść: instrukcje, zasadniczy zrąb kalendarza.

Proweniencja: jak w poz. 8 .

Oprawa: jak w poz. 7.

Sygn.: KUL-V 2885/1963.

E. -, L. -, Z. -

12. [cz. 1] Ordo [...] anno 1966, [auctore J[osepho] Żukowicz], Kraków [1965], Wydawnictwo Apostolstwa Modlitwy, Krakowskie Zakłady Graficzne Zakład 1, $15 \mathrm{~cm} ., 128 \mathrm{ss}$.

Treść: zasadniczy zrąb kalendarza. 
Proweniencja: jak w poz. 8

Uwagi: karty do wyrywania.

Oprawa: jak w poz. 7.

Sygn.: KUL-V 2885/1966.

E. - , L. - , Z. -

13. [cz. 1] Kalendarz liturgiczny Polskich Prowincji Towarzystwa Jezusowego na rok 1969, oprac. Józef Żukowicz, Kraków [1968], Wydawnictwo Apostolstwa Modlitwy, Drukarnia Związkowa, 17 cm., $140 \mathrm{ss}$, [2] kk. lendarza

Treść: rubryki brewiarza, zasadniczy zrąb ka-

Uwagi:zmianatytułu schematyzmuzmianaw stosunku do poz. 1.; jęz. pol.

Oprawa: jak w poz. 7.

Sygn.: KUL-V 2885/1969.

E. - , L. - , Z. -

14. [cz. 1] Kalendarz [...] na rok 1970, oprac. Józef Żukowicz, Kraków [1969], Wydawnictwo Apostolstwa Modlitwy, Drukarnia Związkowa, 15 cm., 148 ss.

Treść: rubryki mszału i in., zasadniczy zrąb kalendarza.

Uwagi: całość w jęz. pol.

Oprawa: jak w poz. 7.

Sygn.: KUL-V 2885/1970.

E. - , L. - , Z. -

15. [cz. 1] Kalendarz [...] na rok 1971, oprac. Józef Żukowicz SI, Kraków [1970], Wydawnictwo Apostolstwa Modlitwy, [b.d.], 15 cm., 297, [6] ss.

Treść: rubryki bewiarza i in., zasadniczy zrąb kalendarza.

Uwagi: jak w poz. 14.

Oprawa: jak w poz. 7.

Sygn.: KUL-V 2885/1971.

E. - , L. - , Z. -

16. [cz. 1] Kalendarz [...] na rok 1972, oprac. Józef Żukowicz SI, Kraków [1971], Wydawnictwo Apostolstwa Modlitwy, Krak. Zakł. Graf., Zakł. nr 3, 17 cm., 186, [1] ss.
Treść: [instrukcje], zasadniczy zrąb kalendarza.

Uwagi: jak w poz. 14.

Oprawa: jak w poz. 7.

Sygn.: KUL-V 2885/1972.

E. - , L. - , Z. -

17. [cz. 1] Kalendarz [...] na rok 1973, oprac. Józef Żukowicz SI, Kraków [1972], Wydawnictwo Apostolstwa Modlitwy, Krak. Zakł. Graf. nr 1, 16 cm.,183, [1] ss., [2] kk.

Treść: jak w poz. 16.

Uwagi: jak w poz. 14.

Oprawa: jak w poz. 7.

Sygn.: KUL-V 2885/1973.

E. - , L. - , Z. -

18. [cz. 1] Kalendarz [...] na rok 1974, [oprac. Józef Żukowicz SI], Kraków [1973], Wydawnictwo Apostolstwa Modlitwy, Krakowskie Zakłady Graficzne, Zakład nr 3, 17 cm., 222, [6] ss.

Treść: jak w poz. 16, notatki.

Uwagi: jak w poz. 14.

Oprawa: jak w poz. 7.

Sygn.: KUL-V 2885/1974.

E. -, L. -, Z. -

19. [cz. 1] Kalendarz [...] na rok 1975, [oprac. Józef Żukowicz SI], Kraków [1974], Wydawnictwo Apostolstwa Modlitwy, Krak. Zakł. Graf. nr 3, 16 cm., 238, [1] ss.

Treść: jak w poz. 16.

Uwagi: jak w poz. 14.

Oprawa: jak w poz. 7.

Sygn.: KUL-V 2885/1975.

E. - , L. - , Z. -

20. [cz. 1] Kalendarz [...] na rok 1976, [oprac. Józef Żukowicz SI], Kraków [1975], Wydawnictwo Apostolstwa Modlitwy, Drukarnia Narodowa, Zakład nr 3, 17 cm., 335 ss.

Treść: jak w poz. 16.

Uwagi: jak w poz. 14.

Oprawa: jak w poz. 7.

Sygn.: KUL-V 2885/1976. 
E. - , L.,- Z. -

21. [cz. 1] Kalendarz [...] na rok 1977, [oprac. Józef Żukowicz SI], Kraków [1976], Wydawnictwo Apostolstwa Modlitwy, Drukarnia Narodowa Zakł. 3, 16 cm., $195,[1]$ ss.

Treść: jak w poz. 16.

Uwagi: jak w poz. 14

Oprawa: jak w poz. 7 .

Sygn.: KUL-V 2885/1977.

E. - L. - Z. -

22. [cz. 1] Kalendarz [...] na rok 1978, [oprac. Józef Żukowicz SI], Kraków [1977], Wydawnictwo Apostolstwa Modlitwy, Drukarnia Narodowa-3, 16 cm., 232 ss.

Treść: jak w poz. 16.

Uwagi: jak w poz. 14.

Oprawa: jak w poz. 7.

Sygn.: KUL-V 2885/1978.

E. -, L. -, Z. -

23. [cz. 1] Kalendarz [...] na rok 1979, [oprac. Józef Żukowicz SI], Kraków [1978], Wydawnictwo Apostolstwa Modlitwy, Drukarnia Narodowa-3, 16 cm., 272 SS.

Treść: jak w poz. 16.

Uwagi: jak w poz. 14

Oprawa: jak w poz. 7.

Sygn.: KUL-V 2885/1979.

E. -, L. - Z. -

24. [cz. 1] Kalendarz [...] na rok 1980, [oprac. Józef Żukowicz SI], Kraków [1979], Wydawnictwo Apostolstwa Modlitwy, Drukarnia Narodowa, 16 cm., 229, [1] ss.

Treść: jak w poz. 18.

Uwagi: jak w poz. 14

Oprawa: jak w poz. 7.

Sygn.: KUL-V 2885/1980.

E. -, L. - , Z. -

25. [cz. 1] Kalendarz [...] na rok 1981, [oprac. Józef Żukowicz SI], Kraków
[1980], Wydawnictwo Apostolstwa Modlitwy, Drukarnia Narodowa 3, 16 cm., 239 ss.

Treść: jak w poz. 18.

Uwagi: jak w poz. 14.

Oprawa: jak w poz. 7.

Sygn.: KUL-V 2885/1981.

E. - L. - , Z. -

26. [cz. 1] Kalendarz [...] na rok 1982, [oprac. Józef Żukowicz SI], Kraków [1981], Wydawnictwo Apostolstwa Modlitwy, Drukarnia Narodowa 3, 16 cm., 239 ss.

Treść: jak w poz. 18.

Uwagi: jak w poz. 14.

Oprawa: jak w poz. 7.

Sygn.: KUL-V 2885/1982.

E. -, L. - , Z. -

27. [cz. 1] Kalendarz [...] na rok 1983, [oprac. Józef Żukowicz SI], Kraków [1982], Wydawnictwo Apostolstwa Modlitwy, Drukarnia Narodowa, $16 \times 5$ cm., 222, [1] ss.

Treść: jak w poz. 16.

Uwagi: jak w poz. 14.

Oprawa: jak w poz. 7.

Sygn.: KUL-V 2885/1983.

E.,- L. - , Z. -

28. [cz. 1] Kalendarz [...] na rok 1983, [oprac. Józef Żukowowicz SI], Kraków 1982, Wydawnictwo Apostolstwa Modlitwy, 17 cm., 222, [1] ss.

Treść: jak w poz. 16.

Uwagi: jak w poz. 14.; błędnie zakwalifikowany do sygn. KUL-V 16954, która obejmuje kalendarze liturgiczne pallotynów.

Oprawa: papier wydaw., napis podobny jak na str. tyt.

Sygn.: KUL-V 16954/1983.

E. -, L. -, Z. -

29. [cz. 1] Kalendarz [...] na rok 1984, [oprac. Józef Żukowicz SI], Kraków [1983], Wydawnictwo Apostolstwa Modlitwy, Drukarnia Narodowa Zakład nr 3, 16 cm., 231 ss. 
Treść: jak w poz. 18.

Uwagi: jak w poz. 14.

Oprawa: jak w poz. 7.

Sygn.: KUL-V 2885/1984.

E. - , L. - , Z. -

30. [cz. 1] Kalendarz [...] na rok 1985, [oprac. Józef Żukowicz SI], Kraków [1984], Wydawnictwo Apostolstwa Modlitwy, Drukarnia Narodowa Zakład nr 3, 16 cm., 224 ss.

Treść: jak w poz. 16.

Uwagi: jak w poz. 14.

Oprawa: jak w poz. 7.

Sygn.: KUL-V 2885/1985.

E. - , L. - , Z. -

31. [cz. 1] Kalendarz [...] na rok 1986, [oprac. ks. Józef Żukowicz SI], Kraków [1985], Wydawnictwo Apostolstwa Modlitwy, Drukarnia Narodowa Zakład nr $3,16 \mathrm{~cm} ., 231 \mathrm{ss}$.

Treść: jak w poz. 18.

Uwagi: jak w poz. 14.

Oprawa: jak w poz. 7.

Sygn.: KUL-V 2885/1986.

E. - , L. - , Z. -

32. [cz. 1] Kalendarz [...] na rok 1987, [oprac. Józef Żukowicz SI], Kraków [1986], Wydawnictwo Apostolstwa Modlitwy, Drukarnia Narodowa Zakład nr 3, $11 \times 16 \mathrm{~cm}$., $55 \mathrm{ss}$.

Treść: jak w poz. 18.

Uwagi: jak w poz. 14.

Oprawa: jak w poz. 7.

Sygn.: KUL-V 2885/1987.

E. - , L. - , Z. -

33. [cz. 1] Kalendarz [...] na rok 1988, [oprac. Józef Żukowicz SI], Kraków [1987], Wydawnictwo Apostolstwa Modlitwy, Drukarnia Narodowa Zakład nr 3, 17 cm., 112 ss.

Treść: jak w poz. 18.

Uwagi: jak w poz. 14.

Oprawa: jak w poz. 7.

Sygn.: KUL-V 2885/1988.
E. -, L. - , Z. -

34. [cz. 1] Kalendarz [...] na rok 1989, [oprac. Józef Żukowicz SI], Kraków [1988], Wydawnictwo Apostolstwa Modlitwy, Drukarnia Narodowa Zakład nr 3, 16 cm., 128 ss.

Treść: jak w poz. 16.

Uwagi: jak w poz. 14.

Oprawa: jak w poz. 7.

Sygn.: KUL-V 2885/1989.

E. - , L. - , Z. -

35. [cz. 1] Kalendarz [...] na rok 1991, [oprac. Józef Żukowicz SI], Kraków [1990], Wydawnictwo Apostolstwa Modlitwy, Zakład Małej Poligrafii Prowincji Polski Południowej Tow. Jezus., 15 cm., 160 sS.

Treść: jak w poz. 18.

Uwagi: jak w poz. 14.

Oprawa: jak w poz. 7 .

Sygn.: KUL-V 2885/1991.

E. - , L. - , Z. -

36. [cz. 1] Kalendarz [...] na rok 1992, [oprac. Józef Żukowicz SI], Kraków [1991], Wydawnictwo Apostolstwa Modlitwy, [b. d.], $15 \mathrm{~cm} ., 231 \mathrm{ss}$.

Treść: jak w poz. 18.

Uwagi: jak w poz. 14.

Oprawa: jak w poz. 7.

Sygn.: KUL-V 2885/1992.

E. - , L. - , Z. -

37. [cz. 1] Kalendarz [...] na rok 1993, [oprac. Józef Żukowicz SI], Kraków [1992], Wydawnictwo Apostolstwa Modlitwy, [b. d.], 15 cm., 144 ss.

Treść: jak w poz. 18.

Uwagi: jak w poz. 14.

Oprawa: jak w poz. 7.

Sygn.: KUL-V 2885/1993.

E. -, L. -, Z. -

38. [cz. 1] Kalendarz [...] na rok 1994, [oprac. Józef Żukowicz SI], Kraków [1993], Wydawnictwo WAM, [b. d.], 14 cm., 144, [2] ss. 
Treść: jak w poz. 18.

Uwagi: jak w poz. 14.

Oprawa: jak w poz. 7.

Sygn.: KUL-V 2885/1994.

E. - , L. - , Z. -

39. [cz. 1] Kalendarz [...] na rok 1995, [oprac. Józef Żukowicz SI], Kraków [1994], Wydawnictwo Apostolstwa Modlitwy, $15 \mathrm{~cm} ., 167 \mathrm{ss}$.

Treść: jak w poz. 18.

Uwagi: jak w poz. 14.

Oprawa: jak w poz. 7.

Sygn.: KUL-V 2885/1995.

E. - , L. - , Z. -

40. [cz. 1] Kalendarz [...] na rok 1999, [oprac. Józef Żukowicz SI], Kraków [1998], Wydawnictwo WAM, 15 cm., 183 ss.

Treść: jak w poz. 18.

Uwagi: jak w poz. 14

Oprawa: jak w poz. 7.

Sygn.: KUL-V 2885/1999.

E. -, L. - Z. -

41. [cz. 1] Kalendarz [...] na rok 2000, [oprac. Józef Żukowicz SI], Kraków [1999], Wydawnictwo WAM, 15 cm., 183 ss.

Treść: jak w poz. 18.

Uwagi: jak w poz. 14.

Oprawa: jak w poz. 7 .

Sygn.: KUL-V 2885/2000.

E. - , L. - , Z. -

42. [cz. 1] Kalendarz [...] na rok 2001, [oprac. ks. Józef Żukowicz SI], Kraków [2000], Wydawnictwo WAM, Drukarnia WAM, $15 \mathrm{~cm} ., 183 \mathrm{ss}$.

Treść: jak w poz. 18.

Uwagi: jak w poz. 14.

Oprawa: jak w poz. 7.

Sygn.: KUL-V 2885/1999.

E. - , L. - , Z. -

43. [cz. 1] Kalendarz [...] na rok 2002, [oprac. Józef Żukowicz SI], Kraków
[2001], Wydawnictwo WAM, Drukarnia WAM, $15 \mathrm{~cm} ., 182$, [1] ss.

Treść: jak w poz. 18.

Uwagi: jak w poz. 14.

Oprawa: jak w poz. 7.

Sygn.: KUL-V 2885/2002.

E. -, L. - Z. -

44. [cz. 1] Kalendarz [...] na rok 2003, [oprac. ks. Józef Żukowicz SI], Kraków [2002], Wydawnictwo WAM, Drukarnia WAM, $15 \mathrm{~cm} ., 191 \mathrm{ss}$.

Treść: jak w poz. 18.

Uwagi: jak w poz. 14.

Oprawa: jak w poz. 7.

Sygn.: KUL-V 2885/2003.

E. -, L. -, Z. -

\section{KAPUCYNI}

Zakon Braci Mniejszych Kapucynów (Ordo Fratrum Minorum Capuccinorum - OFMCap).

Zakon zatwierdzony został w $1528 \mathrm{r}$. we Włoszech, a autonomicznie działał od 1619 r. Po wcześniejszych, nieudanych próbach, kapucyni zostali ostatecznie sprowadzeni do Polski w 1681 r. dzięki inicjatywie króla Jana III Sobieskiego.

W 1754 r. została utworzona prowincja polska pw. św. Wojciecha i Stanisława Bpa (X.1). W 1810 r., status prowincji polskiej przejęły klasztory znajdujące się na ziemiach, które po III zaborze zajęły Austria i Prusy, a następnie weszły w skład Księstwa Warszawskiego i Królestwa Polskiego. Stan taki przetrwał do 1864 r., kiedy to wskutek kasat popowstaniowych, większość placówek uległa likwidacji. Do I wojny światowej wegetowały jeszcze 3 domy (dom krakowski został przekazany pod jurysdykcję prowincji galicyjskiej).

W 1796 r. klasztory na ziemiach przyłączonych do Rosji, które do tej pory stanowiły kontynuacje prowincji polskiej, powołały do życia prowincję ruską (X.2. Prowincja ruska, potem zakon w Rosji). 
Z kolei rozbiory przyczyniły się do odizolowania klasztorów w zaborze austriackim i utworzenia przez nie w 1785 r. prowincji pw. św. Wojciecha i Jana Nepomucena (X.3. Prowincja galicyjska). Pierwszy kalendarz kapucynów w zbiorze BU KUL z 1886 r. zawiera, co prawda w swoim tytule nazwę i wezwanie prowincji polskiej jednak dołączony schematyzm obejmujący zakonników z terenu Galicji pozwala przypuszczać, iż właśnie tego obszaru dotyczy.

W 1912 r. prowincja galicyjska została zredukowana do rangi komisariatu galicyjskiego (w latach 1912-1921). Po zakończeniu I wojny światowej warunki nie sprzyjały powstaniu prowincji. Ustanowiono jedynie komisariaty krakowski (dawniej galicyjski) oraz warszawski (dawna prowincja polska). Dopiero w 1939 r. komisariat krakowski został podniesiony do rangi prowincji pw. św. Józefa Oblubieńca NMP (X.4. Komisariat krakowski, prowincja krakowska). Prowincja warszawska erygowana została w 1952 r. a jej podstawę stanowił dotychczasowy komisariat warszawski (X.5. Prowincja warszawska).

Wspólny dla funkcjonującej prowincji krakowskiej i warszawskiej schematyzm wymieniono osobno (X.6. Kapucyni. Schematyzm prowincji na terenie Polski).

\section{X.1. PROWINCJA POLSKA W KRÓLESTWIE POLSKIM} (do 1864)

1. [cz. 1] Ordo divini officii recitandi missaeque celebrandae juxta rubricas Breviarii Missalisq. rni et nostri peculiaris ad usum FF. Minor. S.P. Francisci Capucinorum Provinciae Polonae SS. Adalberti et Stanislai Episco. Mm. pro anno 1827 constructus, [b.m. 1827], [b.w.d.], 17 cm., [56] SS.

Treść: zasadniczy zrąb kalendarza.

Proweniencja: pieczątka $\mathrm{z}$ napisem: „Biblioteka OO. Bernardynów Kraków”.
Oprawa: brak.

Sygn.: KUL V-10594/1827.

E. - , L. - , Z. -

2. [cz. 1] Ordo divini officii recitandi missaeque celebrandae juxta rubricas Breviarii Missalisque Romani ac nostri peculiaris ad usum Frum. Min. S.P. Francisci Capucinorum Provinciae Polonae SS. Adalberti et Stanislai Episco. Mm. pro anno bissextili 1828 constructus, [b.m. 1827], [b.w.d.], 18 cm., [48] ss., egz. interfol. [4] kk.

Treść: jak w poz. 1.

Uwagi: zmiana tytułu kalendarza w stosunku do poz. 1; notatki; ucięte rogi kart, na kartach interfoliowanych znaki wodne, błędna sygn. Powinno być: KUL V-10594/1828.

Oprawa: tektura, twarda.

Sygn.: KUL V-10594/1824

E. - , L. - , Z. -

3. [cz. 1] Ordo divini officii recitandi missaeque celebrandae juxta calendarium et rubricas Breviarii Missalisque Romani ac nostri peculiaris novissime ad usum FFr. Minor. S.P. Francisci Capucinorum editi Provinciae Poloniae SS. Adalberti et Stanislai Episcoporum et Martyrum pro anno 2 post bissextilem 1854 constructus, Varsaviae [1853] [b.w.], ad Sanctam Crucem, 18 cm., 50, [4] ss.

Treść: zasadniczy zrąb kalendarza, modlitwy w jęz. pol.

Uwagi: zmiana tytułu kalendarza w stosunku do poz. 2; napis atramentem: ,ad Chorum” dalsza część nieczytelna.

Oprawa: papier wydaw., napis: „Ordo divini officii. Varsaviae 1854. K”.

Sygn.: KUL V-10594/1854.

E. - , L. - , Z. -

4. [cz. 1] Ordo [...] pro anno 3 post bissextilem 1859 constructus, Varsaviae [1858], [b.w.], 18 cm., ad Sanctam Crucem, 54 ss., egz. interfol. [4] kk.

Treść: jak w poz. 3 .

Proweniencja: pieczęć owalna z napisem: „Bi- 
blioteka O.O. Bernardynów w Krakowie”.

Uwagi: tytuł kalendarza, jak w poz. 3 ze zmianą - zmiast: [...] FFr. Minor. S.P. Francisci Capucinorum [...], jest: [...] FFr. Minor. S.P. Francisci Sera. Capuccinorum [...]"; karty wycięte, notatki odręczne.

Oprawa: tektura, półskórek, napis złocony: „1859”.

Sygn.: KUL V-10594/1859.

E. cz. 1, t. 3, s. 808, L. -, Z. -

5. [cz. 1] Rubricella ad usum FF. Minorum S. Francisci Capucinorum Provinciae Polonae Sanctorum Adalberti et Stanislai Episcoporum et Martyrum conscripta ac edita pro Anno Domini 1875, Varsaviae [1874], [b.w.], Drukarnia Okręgu Naukowego Warszawskiego, $19 \mathrm{~cm}$., 38, [4] ss.

Treść: jak w poz. 3 .

[cz. 1a] Elenchus mortuorum qui proxime elapso anno in Domino obierunt, s. 35 .

Uwagi: zmiana tytułu kalendarza w stosunku do poz. 3, wykaz zmarłych zakonników z terenu Królestwa Polskiego.

Oprawa: papier, miękka, napis jak na str. tyt.

Sygn.: KUL V-10594/1875.

E. cz. I, t. 11, s. 76, L. -, Z. -

6. [cz. 1] Rubricella [...] pro Anno Domini 1890, Cracoviae 1890, sumptibus PP. Capucinorum, E Typographia Ephemeridum „Czas” Fr. Kluczycki \& Soc., provisore Josepho Łakociński, $18 \mathrm{~cm}$., 48 ss.

Treść: jak w poz. 1, Decreta. s. 46 .

[cz. 1a] Anno vero currenti obierunt,

Uwagi: błędna sygn. Powinno być: KUL V10594/1890, wykaz zmarlych zakonników z terenu Galicji.

Oprawa: jak w poz. 5.

Sygn.: KUL V-10594/1890.

E. - , L. - , Z. -

7. [cz. 1] Rubricella ad usum FF. Minorum S. Francisci Capucinorum Provinciae Polonae Sanctorum Adalberti et Stanislai Episcoporum et Martyrum conscripta ac edita pro Anno Domini 1891, Cracoviae 1891, [b.w.], E Typographia Ephemeridum „Czas” Fr. Kluczycki \& Soc., provisore Josepho Łakociński, 18 cm., 38 ss., [1] k.

Treść: jak w poz. 1, Tabula chronologica.

[cz. 1a] Elapso vero obierunt, s. 38.

Uwagi: zmiana tytułu kalendarza w stosunku do poz. 5; wykaz zmarłych zakonników z terenu Galicji.

Oprawa: jak w poz. 5.

Sygn.: KUL V-10594/1891.

E. - , L. - , Z. -

8. [cz. 1] Ordo divini officii ac missarum ad usum Fr. Minorum S.P. Francisci Capuccinorum Provinciae Polonae sub protectione SS. Adalberti et Stanislai EE. MM. conscriptus ac editus pro Anno Domini 1911, Varsaviae [1910], [b.w.], Typis „Polak-Katolik” et „Posiew”, 18 cm., 69 Ss, [1] k.

Treść: Privilegium celebrandi missam [...], jak w poz. 1 .

[cz. 2] Elenchus patrum ac fratrum Provinciae Polonae, s. 67-69.

Treść: wykaz zakonników w poszczególnych domach zakonnych; wykaz zmarłych zakonników z terenu Królestwa Polskiego.

Uwagi: zmiana tytułu kalendarza w stosunku do poz. 7 .

Oprawa: papier, miękka, oryginalna, napis jak na str. tyt.

Sygn.: KUL V-10594/1911.

E. - , L. - , Z. -

\section{X.2. PROWINCJA RUSKA, POTEM ZAKON W ROSJI (1796-1888)}

1. [cz. 1] Ordo divini officii recitandi missaeque celebrandae juxta calendarium et rubricas Breviarii Missalisque Romani ac nostri peculiaris novissimi ad usum FF. Minorum S.P.N. Francisci Capucinorum Provinciae Russiae juxta normam calendarii veteris, pro Anno Domini post bissextilem secundo MDCCCLXII [1862] constructus, Vilane 1861, [b.w.], Typis A. Mar- 
cinkowski, $16 \mathrm{~cm} ., 66$ ss.

Treść: zasadniczy zrąb kalendarza, modlitwy w jęz. pol.

[cz. 2] Cathalogus partum ac fratrum Ordinis Capucinorum, s. 62-66.

Treść: skład osobowy domów zakonnych, De festis suppressis.

Oprawa: papier, miękka, na okładce napis ołówkiem ,1862”.

Sygn.: KUL-V 17801/1862.

E. - , L. - , Z. -

2. [cz. 1] Ordo divini officii recitandi sacrique peragendi ad usum Fratrum Minorum S.P.N. Francisci Capucinorum in Annum Domini 1887 dispositus sub protectione SS. Adalberti et Stanislai EE. et MM., Varsaviae [1887], [b.w.], Typis Stanislai Niemiera, $18 \mathrm{~cm}$., 60, [2] ss, [1] k.

Treść: jak w poz. 1, Notanda, biogram papieża, modlitwy w jęz. łac., wykaz świąt kościelnych i rządowych.

[cz. 2] Catalogus patrum ac fratrum, [2] ss.

Treść: skład osobowy poszczególnych domów zakonnych byłej prowincji ruskiej.

Uwagi: zmiana tytułu kalendarza w stosunku do poz. 1; dołączony schematyzm klasztorów prowincji ruskiej.

Oprawa: papier, miękka, napis jak na str. tyt.

Sygn.: KUL V-10594/1887.

E. - , L. - , Z. -

\section{X.2. PROWINCJA GALICYJSKA (1785-1912)}

1. [cz. 1] Rubricella ad usum FF. Minorum SPN. Francisci Capucinorum Provinciae Polonae SS. MM. Adalberti et Stanislai Ep. conscripta ac edita pro Anno Domini 1885, Cracoviae 1885, sumptibus PP. Capucinorum, E Typographia Ephemeridum „Czas” Fr. Kluczycki \& Soc., provisore Josepho Łakociński, $18 \mathrm{~cm}$., 50 ss.

Treść: zasadniczy zrąb kalendarza.

Oprawa: papier, miękka, napis jak na str. tyt., brak ostatnich stron i tylnej oprawy.
Sygn.: KUL V-10594/1885.

E. -, L. -, Z. -

2. [cz. 1] Rubricella ad usum FF. Minorum S. Francisci Capucinorum Provinciae Polonae Sanctorum Adalberti et Stanislai Episcoporum et Martyrum conscripta ac edita pro Anno Domini 1886, Cracoviae 1886, [b.w.] E Typographia Ephemeridum „Czas” Fr. Kulczycki \& Soc., provisore Josepho Łakociński, $18 \mathrm{~cm}$., 64 ss.

Treść: jak w poz. 1.

[cz. 2] Schematismus Ordinis Minorum S.P.N. Francisci Capucinorum Provinciae Galiciae pro anno a Christo nato MDCCCLXXXVI [1886], s. 57-64, [1] k.

Treść: władze zakonu, skład osobowy poszczególnych domów zakonnych.

Uwagi: zmiana tytułu kalendarza w stosunku do poz. 1 .

Oprawa: papier, miękka, napis jak na str. tyt.

Uwagi: brak stron 55-56.

Sygn.: KUL V-10594/1886.

E. - , L. - , Z. -

3. [cz. 2] Schematismus Ordinis Minorum S.P.N. Francisci Capuccinorum almae Provinciae Galicianae pro anno a Christo nato 1895, Cracoviae 1894, [b.w.], Typographya [!] A. Koziański, 19 cm., 32 ss.

Treść: pontyfikat aktualnego papieża, władze Zakonu, Series [...] Patrum Ministrorum Generalium, Origo Provinciae, skład osobowy poszczególnych domów zakonnych (w tym w Królewstwie Polskim i ziemiach wcielonych do Rosji), Series sacerdotes et clericorum [...], Series fratrum laicorum [...], Conspectus summarius, Obierunt in Domino.

Uwagi: zmiana tytułu schematyzmu w stosunku do poz. 2; błędna sygn. Powinno być: KUL-V $16747 / 1895$.

Oprawa: brak.

Sygn.: KUL-V 16747/1894.

E. - , L. - , Z. poz. 730 .

4. [cz. 1] Rubricella ad usum Fr. Minorum S.P.N. Francisci Capucinorum Provinciae Galicianae pro Anno Domini 1904, Cracoviae 1904, sumptibus PP. Capucino- 
rum, E Typographia Ephemeridum „Czas”, $18 \mathrm{~cm} ., 48 \mathrm{ss}$.

Treść: zasadniczy zrąb kalendarza, Monita.

[cz. 1a] Obierunt in Domino, s. 48.

Uwagi: zmiana tytułu kalendarza w stosunku do poz. 2.

Oprawa: jak w poz. 2.

Sygn.: KUL V-10594/1904.

E. - , L. - , Z. -

5. [cz. 1] Rubricella [...] pro Anno Domini 1908, Ressoviae 1907, sumptibus PP. Capucinorum, Typis J. A. Pelar, $18 \mathrm{~cm}$., 40 ss.

Treść: jak w poz. 1.

[cz. 1a] Obierunt in Domino, s. 40.

Oprawa: jak w poz. 2.

Sygn.: KUL V-10594/1904.

E. -, L. -, Z. -

\section{X.4. KOMISARIAT KRAKOWSKI (1921-1939) PROWINCJA KRAKOWSKA (1939-)}

1. [cz. 2] Schematismus Ordinis Minorum S.P. Francisci Capuccinorum Provinciae Cracoviensis, dispositus mense Januario 1937, Cracoviae [1936], sumptibus et typis Prov. PP. Capuccinorum, $20 \mathrm{~cm}$., 39 ss.

Treść: pontyfikat aktualnego papieża, władze Zakonu, skład osobowy poszczególnych domów zakonnych, Series [...] Moderatorum Provincialium, Brevis historia, Series alphabetica.

Uwagi: do schematyzmu dołączony Status Familiarum in Conventibus Commissariatus Cracoviensis Ord.Fr.Fr. Min.Capuccinorum ex die 1 Martii an. 1938 w formie plakatu.

Oprawa: papier, miękka, napis jak na str. tyt.

Sygn.: KUL-V 16747/1937.

E. -, L. -, Z. poz. 730 .

2. [cz. 1] Rubricella pro Anno Domini 1941 ad usum Fr. Minorum S.P.N. Francisci Capuccinorum Provinciae Cracoviensis et Varsaviensis eiusdemque Ordinis Mo- nialium disposita cura A.R.P. Casmiri a Cracoviae Min. Provinc. Cracov., Cracoviae 1940, [b.w.], Typis Ephem. „Pokój i Dobro", $18 \mathrm{~cm}$., XVI, 60 ss.

Treść: De missis celebrandis iuxta rubricas, zasadniczy zrąb kalendarza.

Uwagi: uzupełnienie tytułu z okładki.

Oprawa: jak w poz. 1.

Sygn.: KUL V-10594/1941.

E. -, L. - , Z. -

3. [cz. 2] Schematismus [...] Cracoviae 1947, Cracoviae [1946/7], [b.w.d.], 14 ss.

Treść: jak w poz. 1, Series sacerdotes et clericorum $[\ldots]$, Obierunt in Domino.

Oprawa: jak w poz. 1.

Sygn.: KUL-V 16747/1947.

E. -, L. -, Z. -

4. [cz. 1] Rubricella pro Anno Domini 1946 [...], Cracoviae 1945, [b.w.], Typis „Powściągliwość i Praca”, 18 cm., XV, 64 ss.

Treść: jak w poz. 2.

Oprawa: jak w poz. 1.

Sygn.: KUL V-10594/1946.

E. - , L. - , Z. -

5. [cz. 1] Rubricella pro Anno Domini $1950[\ldots]$ disposita cura A.R.P. Aloisi a Kombornia min. provinc. Cracov., Cracoviae 1949, [b.w.], Typis „Patria”, 18 cm., XVI, 61 ss., [1] k.

Treść: jak w poz. 3 .

Uwagi: zmiana tytułu kalendarza w stosunku do poz. 2.

Oprawa: jak w poz. 1.

Sygn.: KUL V-10594/1950.

E. -, L. - , Z. -

6. [cz. 2] Rocznik Zakonu Braci Mniejszych św. O.N. Franciszka Kapucynów Prowincji Krakowskiej św. Józefa na Rok Jubileuszowy 1950, Kraków [1949], Kuria Prowincjalna, [b.d.], 20 cm., 80 ss. 
Treść: władze zakonu, skład osobowy poszczególnych domów zakonnych, adresy, szczegółowe informacje.

Uwagi: zmiana tytułu schematyzmu w stosunku do poz. 1; całość w jęz. pol.

Oprawa: jak w poz. 1.

Sygn.: KUL-V 11646/1950.

E. - , L. - , Z. -

7. [cz. 2] Katalog Krakowskiej Prowincji Zakonu Braci Mniejszych Kapucynów, stan prowincji z dnia 1 lutego 2004, red. Jerzy Ciupak, Kraków 2004, Kuria Prowincjalna Braci Mniejszych Kapucynów, Poligrafia Inspektoratu Towarzystwa Salezjańskiego, 24 cm., 138, [2] ss. + zdjęcia.

Treść: jak w poz. 6.

Uwagi: zmiana tytułu schematyzmu w stosunku do poz. 6; jak w poz. 6 .

Oprawa: papier wydaw., miękka.

Sygn.: KUL-V 36958/2004.

E. - , L. - , Z. -

\section{X.5. PROWINCJA WARSZAWSKA} (1952-)

1. [cz. 2] Katalog Warszawskiej Prowincji Braci Mniejszych Kapucynów, [stan z dnia 14 października 1995], [b.m. 1994], [b.w.d.], 21 cm., 41, [5] ss.

Treść: władze Zakonu, skład osobowy poszczególnych domów zakonnych, adresy., szczegółowe informacje.

Uwagi: całość w jęz. pol., kserokopia.

Oprawa: papier, miękka, wizerunek św. Franciszka.

Sygn.: KUL-V 33416/1995.

E. - , L. - , Z. -

2. [cz. 2] Katalog [...], stan z dnia 15 października 1997 roku, oprac. Grzegorz Suchański OFMCap., Warszawa 1997, [b. w.], dr. Kuria Prowincjonalna, $21 \mathrm{~cm} ., 45$ ss.

Treść: jak w poz. 1.

Uwagi: całość w jęz. pol.
Oprawa: papier, miękka, wizerunek Chrystusa Ukrzyżowanego w otoczeniu św Franciszka i św. Klary.

Sygn.: KUL-V 33416/1995.

E. -, L. - , Z. -

3. [cz. 2] Katalog [...], stan z dnia 23 listopada 1998 roku, oprac. Grzegorz Suchański OFMCap., Warszawa 1998, [b.w.], dr. Kuria Prowincjonalna, 20 cm., 59 ss.

Treść: jak w poz. 1.

Uwagi: jak w poz. 2

Oprawa: jak w poz. 7.

Sygn.: KUL-V 33416/1998.

E. - , L. - , Z. -

4. [cz. 2] Jubileuszowy katalog Zakonu Braci Mniejszych Kapucynów Prowincji Warszawskiej 1952-2002, red. Ryszard Matyka, Roland Prejs, Warszawa 2002, Bracia Mniejsi Kapucyni, Drukarnia Diecezjalna, $24 \mathrm{~cm} ., 183$ ss. + zdjęcia.

Treść: jak w poz. 1.

Uwagi: zmiana tytułu schematyzmu w stosunku do poz. 1 ; jak w poz. 3 .

Oprawa: papier, miękka, napis podobny jak na str. tyt., znak jubileuszowy Warszawskiej Prowincji Kapucynów.

Sygn.: KUL-V 33416/2002.

E. - , L. - , Z. -

\section{X.6. KAPUCYNI. SCHEMATYZM PROWINCJI NA TERENIE POLSKI}

1. [cz. 2] Katalog Polskich Prowincji Ojców Kapucynów [1979], stan z dnia 31.12.1978 r., red. Czesław Biedulski, Rzym-Warszawa 1979, wyd. Prowincje Kapucyńskie w Polsce, Drukarnia „Abilgraf", 21 cm., 209 ss. + zdjęcia, mapa.

Treść: władze Zakonu, skład osobowy poszczególnych domów zakonnych, adresy., szczegółowe informacje.

Uwagi: całość w jęz. pol.

Oprawa: papier, miękka, wizerunek św. Franciszka.

Sygn.: KUL-V 22284/1979.

E. -, L. -, Z. -, W. poz. 305 . 


\section{KARMELICI}

Zakon Braci Najświętszej Maryi Panny z Góry Karmel (Ordo Fratrum Beatissimae Mariae Virginis de Monte Carmelo-OCarm).

Zakon wywodzący swe początki od ruchu eremickiego w Ziemi Świętej, otrzymał zatwierdzenie reguły w $1226 \mathrm{r}$.

Do Polski zostali sprowadzeni przez królową Jadwigę i Władysława Jagiełłę w 1397 r. Pierwszą ich siedzibą było kościół i klasztor na przedmieściach Krakowa - Na Piasku. Do rozbiorów na ziemiach polskich funkcjonowało pięć prowincji: małopolska, ruska, litewsko-ruska, litewska i wielkopolska.

Po rozbiorach klasztory znajdujące się pod władzą Prus i Rosji zostały stopniowo likwidowane. Sytuacja w państwie austriackim spowodowała, iż klasztory części dawnej prowincji ruskiej miały najbardziej korzystne warunki egzystowania tworząc prowincje galicyjską. W ten sposób przetrwały do 1919 r., kiedy to została utworzona prowincja polska pod tym samym wezwaniem jednak już $\mathrm{w}$ niepodległym państwie.

1. [cz. 1] Ordo divini officii recitandi ad usum FF. Ordinis Bmae Dei Genitiricis V. Mariae de Monte Carmelo A.O.R ex mandato Eximii et Admodum Reverendi $\mathrm{p}$. Engelberti Obermajer, sacrae theologiae magistri, prioris provincialis pro anno $\mathbf{1 8 0 2}$ dispositus, Cracoviae [1801], [b.w.], Typis Academicis, 16 cm., [32] ss., egz. interfol. [2] kk.

Treść: zasadniczy zrąb kalendarza.

Uwagi: napis atramentem na str. tyt. „Carmelita” oraz pieczęć z napisem: „G, 6 X, 12 gr”, reszta nieczytelna.

Oprawa: brak.

Sygn.: KUL-V 7992/1802.

E. cz. 1, t. III, s. 808 , L. - , Z. -

2. [cz. 1] Ordo divini officii juxta ritum et antiquam consuetudinem Hierosolimitanae Ecclesiae ad usum Fratrum Ordi- nis Beatissimae Dei Genitricis semperque Virginis Mariae de Monte Carmelo dispositus pro Anno Domini MDCCCLXXV [1875], Leopoli 1875, in Typographia Ludowa sub directione Stanislai Bayli, 18 cm., [24].

Treść: jak w poz. 1.

Uwagi: zmiana tytułu kalendarza w stosunku do poz. 1; napis atramentem na str. tyt.: „W. X. Wacława Giotuwskiego 5.VIII.1891".

Oprawa: papier wydaw., miękka, napis jak na str. tyt.

Sygn.: KUL-V 7992/1875.

E. -, L. -, Z. -

3. [cz. 2] Schematismus Ordinis Fratrum Beatissimae Virginis Mariae de Monte Carmelo A.R.O. in Provincia Scti Josephi Sponsi B.V.M. Regni Galiciae cum M.D. Cracoviensi anno 1885, Cracoviae 1885, sumptibus PP. Carmelitarum, E Typographia Ephemerid. „Czas” Fr. Kluczycki \& Soc., provisore Josepho Łakociński, 19 cm., 32 ss.

Treść: skład osobowy poszczególnych domów zakonnych, Universim.

Oprawa: jak w poz. 2, na tylnej okładce przedstawienie kościoła karmelitów w Krakowie „Na Piasku".

Sygn.: KUL V-10539/1885.

E. -, L. -, Z. -

4. [cz. 2] Schematismus [...] anno 1886, Cracoviae 1886, sumptibus PP. Carmelitarum, E Typographia Ephemeridum „Czas” Fr. Kluczycki \& Soc., provisore Josepho Łakociński, $19 \mathrm{~cm}$., 32 ss.

Treść: skład osobowy poszczególnych domów zakonnych, Universim, Defuncti.

Oprawa: jak w poz. 2, na tylnej okładce przedstawienie kościoła karmelitów w Bołszowcach.

Sygn.: KUL V-10539/1886.

E. - , L. - , Z. -

5. [cz. 2] Schematismus [...] anno 1887, Cracoviae 1887, sumptibus PP. Carmelitarum, E Typographia Ephemeridum „Czas” Fr. Kluczycki \& Soc., provisore Jo- 
sepho Łakociński, 19 cm., 24 ss.

Treść: jak w poz. 4.

Oprawa: jak w poz. 2.

Sygn.: KUL V-10539/1887.

E. cz. 1, t. IV, s. 123, L. - Z. Z.

6. [cz. 2] Schematismus [...] anno 1888, Cracoviae 1888, sumptibus PP. Carmelitarum, E Typographia Ephemeridum „Czas” Fr. Kluczycki \& Soc., provisore Josepho Łakociński, 19 cm., 29 ss., [1] k.

Treść: Series priorum provincialium Ordinis Carmelitarum, skład osobowy poszczególnych domów zakonnych, Universim, Defuncti.

Oprawa: jak w poz. 2.

Sygn.: KUL V-10539/1888.

E. cz. 1, t. IV, s. 123, L. -, Z. -

7. [cz. 2] Schematismus [...] anno 1889, Cracoviae 1888, sumptibus PP. Carmelitarum, E Typographia Ephemeridum „Czas” Fr. Kluczycki \& Soc., provisore Josepho Łakociński, 19 cm., 29 ss., [1] k.

Treść: jak w poz. 6 .

Oprawa: jak w poz. 2.

Sygn.: KUL V-10539/1889.

E. cz. 1, t. IV, s. 123, L. -, Z. -

8. [cz. 2] Schematismus [...] anno 1890, Cracoviae 1888, sumptibus PP. Carmelitarum, E Typographia Ephemeridum „Czas” Fr. Kluczycki \& Soc., provisore Josepho Łakociński, 19 cm., 30 ss.

Treść: jak w poz. 6.

Oprawa: jak w poz. 2.

Sygn.: KUL V-10539/1890.

E. cz. 1, t. IV, s. 123, L. -, Z. -

9. [cz. 2] Schematismus [...] anno 1891, Cracoviae 1891, sumptibus PP. Carmelitarum, E Typographia Ephemeridum „Czas” Fr. Kluczycki \& Soc., provisore Josepho Łakociński, 19 cm., 35, [4] ss.

Treść: jak w poz. 6 .

Oprawa: jak w poz. 2.

Sygn.: KUL V-10539/1891.

E. -, L. -, Z. -
10. [cz. 2] Schematismus [...] anno 1892, Cracoviae 1892, sumptibus PP. Carmelitarum, E Typographia Ephemeridum „Czas” Fr. Kluczycki \& Soc., provisore Josepho Łakociński, 19 cm., 35, [4] ss.

Treść: jak w poz. 6 .

Oprawa: jak w poz. 2.

Sygn.: KUL V-10539/1892.

E. -, L. -, Z. -

11. [cz. 2] Schematismus [...] anno 1893, Cracoviae 1893, sumptibus PP. Carmelitarum, E Typographia Ephemeridum „Czas” Fr. Kluczycki \& Soc., provisore Josepho Łakociński, 19 cm., 35, [4] ss.

Treść: jak w poz. 6 .

Oprawa: jak w poz. 2.

Sygn.: KUL V-10539/1893.

E. -, L. -, Z. -

12. [cz. 1] Ordo divini officii recitandi missaeque celebrandae iuxta ritum et ant. consuetudinem Hierosolymitanae Ecclesiae Fratrum B. et Gl. Mariae de Monte Carmelo ex mandato A.R.P. M. Mariani Spolski Provincialis Provinciae S. Joseph in Galicia nec non Magno Ducatu Cracoviensi per R.P. Valer. Wierzbicki dispositus pro Anno Domini MDCCCXCIX [1899], Leopoli 1898, impressum in Typographia Catholica Josephi Chęciński, 18 cm., 94, [1] ss.

Treść: jak w poz. 1.

[cz. 2] Schematismus religiosorum Ordinis Carmelitarum ant. Reg. Observ. in Galicia Austriaca et Magno Ducatu Cracoviensi pro Anno Domini 1899, s. 86-94, [1].

Treść: władze zakonu, skład osobowy poszczególnych domów zakonnych, Defuncti.

Uwagi: zmiana tytułu kalendarza w stosunku do poz. 2.

Oprawa: jak w poz. 2.

Sygn.: KUL-V 7992/1899.

E. -, L. -, Z. - 


\section{KARMELICI BOSI}

Bracia Bosi Zakonu Najświętrzej Maryi Panny z Góry Karmel (Fratres Discalceati Ordinis Beatae Mariae Virginis de Monte Carmelo - OCD).

Karmelici bosi przybyli do Polski w 1605 r., a już w 1617 r. rozwijając swoje struktury zakonne, doprowadzili do powstania prowincji polskiej. Kolejny podział administracyjny nastąpił w 1731 r. wydzielający z prowincji polskiej, prowincję litewską. Po okresie kasat, jedynym klasztorem, jaki przetrwał był erem w Czernej (przyłączony w 1885 r. do jednostki austrowęgierskiej). Pod koniec XIX w. sytuacja karmelitów bosych zaczęła się poprawiać. Erygowanie kolejnych klasztorów doprowadziło w 1920 r. do utworzenia prowincji polskiej. Kolejna zmiana nastąpiła dopiero w 1993 r., kiedy to podzielono prowincję polską na warszawską i krakowską.

1. [cz. 1] Ordo divini officii juxta ritum Breviarii et Missalis S. Romanae Ecclesiae ac Ord. Carmelit. Discal. ad usum Provinciae Spiritus Sancti Diciti Ordinis in Polonia pro A.D. 1946, [b.m. 1945], [b.w.], Drukarnia „Powściągliwość i Praca”, 14 cm., 104 ss.

Treść: zasadniczy zrąb kalendarza.

Oprawa: papier wydaw., napis: „Ordo 1946”, herb Zakonu.

Sygn.: KUL-V 7992/1946.

E. - , L. - , Z. -

2. [cz. 1] Ordo divini officii recitandi missaeque celebrandae juxta ritum Breviarii et Missalis S. Romanae Ecclesiae ac Ord. Carmelit. Discal. ad usum Provinciae Spiritus Sancti Diciti Ordinis in Polonia pro A.D. 1949, Cracoviae [1948], Collegium Theologicum sub tit. Immaculatae Conceptionis BMV. O.C.D., Drukarnia „Powściągliwość i Praca”, 15 cm., 98 ss.

Treść: jak w poz. 1.

Uwagi: zmiana tytułu kalendarza w stosunku do poz. 1; strony do wyrywania.
Oprawa: papier wydaw., napis: „Ordo 1949”, herb Zakonu.

Sygn.: KUL-V 7992/1949.

E. - , L. - , Z. -

3. [cz. 1] Ordo divini officii iuxta ritum S. Romanae Ecclesiae ac Ord. Carmelit. Discal. ad usum Provinciae Spiritus S. in Polonia pro A.D. 1956, [Łódź-Radogoszcz 1955], Klasztor Ojców Karmelitów Bosych, Drukarnia Loretańska, 15 cm., 128 ss.

Treść: jak w poz. 1.

Uwagi: zmiana tytułu kalendarza w stosunku do poz. 2.

Oprawa: papier wydaw., napis: „Ordo 1956”.

Sygn.: KUL-V 7992/1956.

E. - , L. - Z. -

4. [cz. 1] Ordo [...] pro A.D. 1957, [Łódź-Radogoszcz 1956], Klasztor Ojców Karmelitów Bosych, Drukarnia Loretańska, $14 \mathrm{~cm} ., 181$, [2] ss.

Treść: jak w poz. 1.

Oprawa: papier wydaw., napis: „Ordo 1957”.

Sygn.: KUL-V 7992/1957.

E. - , L. - , Z. -

5. [cz. 1] Ordo divini officii iuxta ritum S. Romanae Ecclesiae ac Ord. Carmelit. Discal. Provinciae Spiritus S. in Polonia pro A.D. 1958, [Łódź-Radogoszcz 1957], Klasztor Ojców Karmelitów Bosych, Drukarnia Loretańska, 15 cm., 187 ss.

Treść: Decretum generale, zasadniczy zrąb kalendarza.

Uwagi: zmiana tytułu kalendarza w stosunku do poz. 3 .

Oprawa: papier wydaw., brak okładki przedniej.

Sygn.: KUL-V 7992/1958.

E.,- L. - , Z. -

6. [cz. 1] Ordo [...] pro A.D. 1959, Kraków [1958], Wydawnictwo O.O. Karmelitów Bosych [wydawca prowincjał O. O. Karmelitów], Krak. Zakł. Graf.-Zakład 7, 14 cm., 184, [2] ss. 
Treść: jak w poz. 5.

Proweniencja: Biblioteka Uniwersytetu M. Curie-Skłodowskiej w Lublinie.

Uwagi: strony do wyrywania.

Oprawa: papier wydaw., napis: „Ordo 1959”.

Sygn.: KUL-V 7992/1959.

E. - , L. - , Z. -

7. [cz. 1] Ordo [...] pro A.D. 1960 bissextili, [oprac. o. Benedykt od św. Rodziny], Kraków [1959], Wydawnictwo O.O. Karmelitów Bosych, [wydawca prowincjał OO. Karmelitów], Krak. Zakł. Graf. Zakład-3, 15 cm., 192 ss.

Treść: Decretum generale, jak w poz. 1.

Proweniencja: jak w poz. 6.

Uwagi: strony do wyrywania.

Oprawa: papier wydaw., napis: „Ordo 1960”, herb zakonu.

Sygn.: KUL-V 7992/1960.

E. - , L.,- Z. -

8. [cz. 1] Ordo [...] pro A.D. 1961, [oprac. o. Benedykt od św. Rodziny], Kraków [1960], Wydawnictwo O.O. Karmelitów Bosych, [wydawca prowincjał O.O. Karmelitów], Krak. Zakł. Graf.-Zakład nr 7, 10, 184 ss.

Treść: Quae legenda sunt in Refectorio, zasadniczy zrąb kalendarza.

Proweniencja: jak w poz.6.

Oprawa: papier wydaw., napis: „Ordo 1961”, herb zakonu.

Sygn.: KUL-V 7992/1961.

E. -, L. -, Z. -

9. [cz. 1] Ordo [...] pro A.D. 1962, [oprac. o. Benedykt od św. Rodziny], Kraków [1961], Wydawnictwo O.O. Karmelitów Bosych, [wydawca prowincjał O.O. Karmelitów], Krak. Zakł. Graf.-Zakład 7, $14 \mathrm{~cm} ., 153 \mathrm{ss}$.

Treść: jak w poz. 8 .

Proweniencja: jak w poz. 6.

Uwagi: strony do wyrywania.

Oprawa: papier wydaw., napis: „Ordo 1962”, herb zakonu.

Sygn.: KUL-V 7992/1962.
E. - , L.,- Z. -

10. [cz. 1] Ordo [...] pro A.D. 1963, [oprac. o. Benedykt od św. Rodziny], Kraków [1962], Wydawnictwo O.O. Karmelitów Bosych, [wydawca prowincjał O.O. Karmelitów], Krak. Zakł. Graf.-Zakład 7, $15 \mathrm{~cm} ., 169$ ss.

Treść: jak w poz. 8.

Proweniencja: jak w poz. 6 .

Uwagi: strony do wyrywania.

Oprawa: papier wydaw., napis: „Ordo 1963”, herb zakonu.

Sygn.: KUL-V 7992/1963.

E. - , L. - , Z. -

11. [cz. 1] Ordo [...] pro A.D. 1965, [oprac. o. Benedykt od św. Rodziny], Kraków [1964], Wydawnictwo O.O. Karmelitów Bosych, [wydawca prowincjał OO. Karmelitów], Krak. Zakł. Graf. - Zakład nr 1, 14 cm., 201, [2] ss.

Treść: jak w poz. 8 .

Uwagi: strony do wyrywania.

Oprawa: papier wydaw., napis: „Ordo 1965”, herb zakonu.

Sygn.: KUL-V 7992/1965.

E. - , L. - , Z. -

12. [cz. 1] Ordo [...] pro A.D. 1966, [oprac. o. Benedykt od św. Rodziny], Kraków [1965], Wydawnictwo O.O. Karmelitów Bosych, [wydawca prowincjał OO. Karmelitów], Krak. Zakł. Graf. - Zakład nr $1,14 \mathrm{~cm} ., 183$, [2] ss.

Treść: jak w poz. 8 .

Proweniencja: jak w poz. 6.

Uwagi: strony do wyrywania.

Oprawa: papier wydaw., napis: „Ordo 1966”, herb zakonu.

Sygn.: KUL-V 7992/1966.

E. - , L. - , Z. -

13. [cz. 1] Ordo [...] pro A.D. 1967, [oprac. o. Benedykt od św. Rodziny], Kraków [1966], Wydawnictwo O.O. Karmelitów Bosych, [wydawca prowincjał O.O. Karmelitów], Drukarnia Związkowa, 14 cm., 170, [6] ss. 
Treść: jak w poz. 8.

Oprawa: papier wydaw., napis: „Ordo 1967”, herb zakonu.

Sygn.: KUL-V 7992/1967.

E. - , L. - , Z. -

14. [cz. 1] Ordo [...] pro A.D. 1970, [oprac. o. Benedykt od św. Rodziny], Kraków [1969], Wydawnictwo O.O. Karmelitów Bosych, [wydawca prowincjał O.O. Karmelitów], Drukarnia Związkowa, 14 cm., 231 ss.

Treść: Index rerum (w tym m.in. index mortuorum), jak w poz. 1 .

Uwagi: zmiana tytułu w stosunku do poz. 5 ,[...] Ordinis Carmelitarum Discalceatorum Provinciae Spiritus S. in Polonia [...]”.

Oprawa: papier wydaw., napis: „Ordo 1970”, herb zakonu.

Sygn.: KUL-V 7992/1970.

E. -, L. -, Z. -

15. [cz. 1] Kalendarz liturgiczny Karmelitów Bosych Prowincji Polskiej na rok 1972 [...], [oprac. o. Sebastian Ruszczycki], Kraków [1971], Wydawnictwo O.O. Karmelitów Bosych, [wydawca prowincjał O.O. Karmelitów], Drukarnia Wydawnicza, 14 cm., 249, [6] ss.

Treść: Wstęp, dekrety, zasadniczy zrąb kalendarza.

Uwagi: zmiana tytułu kalendarza w stosunku do poz. 5; całość w jęz. pol.

Oprawa: papier wydaw., napis: „Ordo 1972”, herb zakonu.

Sygn.: KUL-V 7992/1972.

E. - , L. - , Z. -

16. [cz. 1] Kalendarz [...] na rok 1974 [...], [oprac. o. Sebastian Ruszczycki], Kraków [1973], Wydawnictwo O.O. Karmelitów Bosych, [wydawca prowincjał O. O. Karmelitów], Drukarnia Związkowa, 14 cm., 262, [3] ss.

Treść: jak w poz. 15.

Uwagi: jak w poz. 15.

Oprawa: papier wydaw., napis jak na str. tyt.

Sygn.: KUL-V 7992/1974.
E. - , L. - , Z. -

17. [cz. 1] Kalendarz [...] na rok 1976 [...], [oprac. o. Sebastian Ruszczycki], Kraków [1975], Wydawnictwo O.O. Karmelitów Bosych, [wydawca prowincjał $\mathrm{O}$. O. Karmelitów], Drukarnia Związkowa, 14 cm., 272 ss.

Treść: jak w poz. 15.

Uwagi: jak w poz. 15.

Oprawa: papier wydaw., napis podobny, jak na str., tyt., herb zakonu.

Sygn.: KUL-V 7992/1976.

E. - , L. - , Z. -

18. [cz. 1] Kalendarz [...] na rok 1977 [...], [oprac. o. Sebastian Ruszczycki], Kraków [1976], Wydawnictwo O.O. Karmelitów Bosych, [wydawca prowincjał OO. Karmelitów], Drukarnia Związkowa, $14 \mathrm{~cm} ., 265$, [5] ss.

Treść: jak w poz. 15.

Uwagi: całość w jęz. pol.

Oprawa: jak w poz. 17.

Sygn.: KUL-V 7992/1977.

E. -, L. - , Z. -

19. [cz. 1] Kalendarz [...] na rok 1978 [...], [oprac. o. Sebastian Ruszczycki], Kraków [1977], Wydawnictwo O.O. Karmelitów Bosych, [wydawca prowincjał O.O. Karmelitów], Drukarnia Związkowa, 14 cm., 223, XII, [6] ss.

Treść: jak w poz. 15.

Uwagi: jak w poz. 15.

Oprawa: jak w poz. 17.

Sygn.: KUL-V 7992/1978.

E. - , L. - , Z. -

20. [cz. 1] Kalendarz [...] na rok 1979 [...], [oprac. o. Sebastian Ruszczycki], Kraków [1978], Wydawnictwo O.O. Karmelitów Bosych, [wydawca prowincjał O. O. Karmelitów], Drukarnia Związkowa, 15 cm., 218, [6] ss.

Treść: jak w poz. 15.

Uwagi: jak w poz. 15 .

Oprawa: jak w poz. 17. 
Sygn.: KUL-V 7992/1979.

E. - , L. - , Z. -

21. [cz. 1] Kalendarz [...] na grudzień 1979 - listopad 1980 [...], [oprac. o. Sebastian Ruszczycki], Kraków [1979], Wydawnictwo O.O. Karmelitów Bosych, [wydawca prowincjał O.O. Karmelitów], Drukarnia Związkowa, 14 cm., 184, LX ss.

Treść: Przegląd Mszy, jak w poz. 1, Liturgia św. Szymona Stock, modlitwy wiernych w liturgii karmelitańskiej.

Uwagi: jak w poz. 15.

Oprawa: jak w poz. 17.

Sygn.: KUL-V 7992/1980

E. - , L. - , Z. -

22. [cz. 1] Kalendarz [...] na grudzień 1980 - listopad 1981 [...], [oprac. o. Sebastian Ruszczycki], Kraków [1980], Wydawnictwo O.O. Karmelitów Bosych, [wydawca prowincjał O.O. Karmelitów], Drukarnia Narodowa, 14 cm., 212 ss.

Treść: Przegląd Mszy, zasadniczy zrąb kalendarza.

Uwagi: jak w poz. 15.

Oprawa: jak w poz. 17.

Sygn.: KUL-V 7992/1981.

E. - , L. - , Z. -

23. [cz. 1] Kalendarz [...] na grudzień 1981 - listopad 1982 [...], [oprac. o. Sebastian Ruszczycki], Kraków [1980], Wydawnictwo O.O. Karmelitów Bosych, [wydawca prowincjał OO. Karmelitów], Drukarnia Narodowa, 14 cm., 198 ss., [5] kk.

Treść: jak w poz. 22.

Uwagi: jak w poz. 15.

Oprawa: jak w poz. 17.

Sygn.: KUL-V 7992/1979/82.

E. - , L. - , Z. -

24. Katalog Zakonu Karmelitów Bosych w Polsce ( stan w dniu 15 października 1982 r.), Warszawa 1982, Kuria Prowincjalna OO. Karmelitów Bosych, [b.d.], 28 cm., 112 ss.
Treść: władze zwierzchnie, rys historyczny Prowincji Polskiej, skład osobowy domów zakonnych (w tym żeńskich).

Uwagi: na stronie tytułowej pieczęć z napisem: „Redakcja Encyklopedii Katolickiej/ Lublin/ Fr. Chopina 27 - V piętro Tel. 286-70”, jak w poz. 15.

Oprawa: jak w poz. 17.

Sygn.: KUL V-36019/1982.

E. - , L. - , Z. -

25. [cz. 1] Kalendarz [...] na grudzień 1982 - listopad 1983 [...], [oprac. o. Sebastian Ruszczycki OCD], Kraków [1981], Wydawnictwo O.O. Karmelitów Bosych, [wydawca prowincjał OO. Karmelitów], Drukarnia Narodowa, 14 cm., 198, [2] ss.

Treść: jak w poz. 22.

Uwagi: jak w poz. 15 .

Oprawa: jak w poz. 17.

Sygn.: KUL-V 7992/1983.

E. - , L. - , Z. -

26. [cz. 1] Kalendarz [.....] na grudzień 1983 - listopad 1984 [...], [oprac. o. Sebastian Ruszczycki OCD], Kraków [1982], Wydawnictwo O.O. Karmelitów Bosych, [wydawca prowincjał O.O. Karmelitów], Drukarnia Narodowa, $14 \mathrm{~cm}$., 226, [2] ss.

Treść: jak w poz. 22.

Uwagi: jak w poz. 15.

Oprawa: papier wydaw., napis podobny jak na str. tyt., z tyłu herb zakonu.

Sygn.: KUL-V 7992/1979/84.

E. -, L. -, Z. -

27. [cz. 1] Kalendarz [...] na grudzień 1984 - listopad 1985 [...], [oprac. o. Sebastian Ruszczycki OCD], Kraków [1983], Wydawnictwo O.O. Karmelitów Bosych, [wydawca prowincjał O.O. Karmelitów], Drukarnia Narodowa, 14 cm., 218, [6] ss.

Treść: jak w poz. 22.

Uwagi: jak w poz. 15.

Oprawa: jak w poz.17.

Sygn.: KUL-V 7992/1985.

E. - , L. - , Z. - 
28. [cz. 1] Kalendarz [...] na grudzień 1985 - listopad 1986 [...], [oprac. o. Sebastian Ruszczycki OCD], Kraków [1985], Wydawnictwo O.O. Karmelitów Bosych, [wydawca prowincjał O.O. Karmelitów], Drukarnia Narodowa, 14 cm., 235, [6] ss.

Treść: jak w poz. 22.

Uwagi: jak w poz. 15, dodane 3 broszurki z modlitwami.

Oprawa: jak w poz. 17.

Sygn.: KUL-V 7992/1986.

E. -, L. -

29. [cz. 1] Kalendarz [...] na grudzień 1986 - listopad 1987 [...], [oprac. o. Sebastian Ruszczycki OCD], Kraków, Wydawnictwo O.O. Karmelitów Bosych, [wydawca prowincjał O.O. Karmelitów], Drukarnia Narodowa, 14 cm., 240 ss.

Treść: jak w poz. 22.

Uwagi: jak w poz. 15.

Oprawa: jak w poz. 17.

Sygn.: KUL-V 7992/1987.

E. - , L. - , Z. -

30. [cz. 1] Kalendarz [...] na grudzień 1988 - listopad 1989 [...], [oprac. o. Sebastian Ruszczycki OCD], Kraków [1987], Wydawnictwo O.O. Karmelitów Bosych, [wydawca prowincjał OO. Karmelitów], Drukarnia Narodowa, 14 cm., 234 ss., [3] kk.

Treść: jak w poz. 22.

Uwagi: jak w poz. 15.

Oprawa: jak w poz. 17.

Sygn.: KUL-V 7992/1989.

E. - , L. - , Z. -

31. [cz. 1] Kalendarz [...] na rok 1990 [...], [oprac. o. Sebastian Ruszczycki OCD], Kraków [1989], Wydawnictwo O. O. Karmelitów Bosych, [wydawca prowincjał O.O. Karmelitów], Drukarnia Narodowa, 14 cm., $264 \mathrm{ss}$.

Treść: jak w poz. 22.

Uwagi: jak w poz. 15.

Oprawa: jak w poz. 17.

Sygn.: KUL-V 7992/1990.

E. - , L. - , Z. -

\section{MISJONARZE}

Zgromadzenie Księży Misjonarzy Świętego Wincentego a Paulo (Congregatio Missionis - CM).

Do Polski sprowadzeni zostali w $1651 \mathrm{r}$. przez Marię Ludwikę Gonzagę, żonę króla Jana Kazimierza. Do rozbiorów funkcjonowała jedna prowincja - polska. W wyniku rozbiorów i kolejnych kasat praktycznie ciagłość zgromadzenia możliwa była dzięki erekcji w 1865 r. prowincji krakowskiej obejmującej obszar Galicji. Po odzyskaniu niepodległości, w ramach II Rzeczypospolitej, doszło do odrodzenia polskiej prowincji Księży Misjonarzy.

1. Sygn.: KUL-V-10459/1939 - brak.

2. [cz. 1] Ordo divini officii recitandi sacrique peragendi iuxta kalendarium Congregationis Missionis pro anno MCMXLIII [1943], Cracoviae 1943, sumptibus Congregationis Missionis, Druk W. L. Anczyc i Sp., $21 \mathrm{~cm} ., 56 \mathrm{ss}$.

Treść: zasadniczy zrąb kalendarza.

Proweniencja: „K. Marian [?] - nazwisko nieczytelne, 1943 27/2" [?].

Uwagi: notatka, na str. tyt. i okładce - herb Zgromadzenia, tytuł uzupełniony z treści kalendarza.

Oprawa: papier wydaw., napis jak na str. tyt.

Sygn.: KUL-V-10459/1943.

E. - , L. - , Z. -

3. Sygn.: KUL-V-10459/1947 - brak.

4. Sygn.: KUL-V-36947/2001 - brak.

5. [cz. 2] Zgromadzenie Księży Misjonarzy św. Wincentego a Paulo. Katalog Rodziny Wincentyńskiej 2002/2003. Rok II, red. Arkadiusz Zakręta CM, Kraków [2002], Kuria Prowincjalna, [Wydawnictwo Instytutu Teologicznego Księży Misjonarzy], $17 \mathrm{~cm} ., 156 \mathrm{ss}$.

Treść: władze Zgromadzeń, obszerne informacje dotyczące zarówno Zgromadzenia Księży Misjonarzy, jak też Zgromadzenia Sióstr Miłosierdzia, Stowarzyszeń, adresy, indeksy. 
Uwagi: na stronie tytułowej herby Zgromadzeń, całość w jęz. pol., adres wydawniczy uzupełniony z treści schematyzmu.

Oprawa: papier wydaw., napis podobny jak na str. tyt..

Sygn.: KUL-V-36947/2 (2002/2003).

E. - , L. - , Z. -

6. [cz. 2] [...] Katalog Rodziny Wincentyńskiej 2003/2004. Rok III, [red. Adam W. Borowski CM], Kraków [2003], Kuria Prowincjalna, [Wydawnictwo Instytutu Teologicznego Księży Misjonarzy], 17 cm., 176 ss.

Treść: jak w poz. 5.

Uwagi: jak w poz. 5 .

Oprawa: jak w poz. 5 .

Sygn.: KUL-V-36947/3 (2003/2004).

E. - , L. - , Z. -

7. [cz. 2] [...] Katalog Rodziny Wincentyńskiej 2004/2005. Rok IV, [red. Adam W. Borowski CM], Kraków [2004], Kuria Prowincjalna, [Wydawnictwo Instytutu Teologicznego Księży Misjonarzy], $17 \mathrm{~cm}$., 208 ss. + fotografie.

Treść: jak w poz. 5.

Uwagi: jak w poz. 5.

Oprawa: jak w poz. 5.

Sygn.: KUL-V-36947/4 (2004/2005).

E. - , L. - , Z. -

8. [cz. 2] [...] Katalog Rodziny Wincentyńskiej 2005/2006. Rok V, [red. Adam W. Borowski CM], Kraków [2005], Kuria Prowincjalna, [Wydawnictwo Instytutu Teologicznego Księży Misjonarzy], $17 \mathrm{~cm}$., 208 ss. + fotografie.

Treść: jak w poz. 5.

Uwagi: jak w poz. 5.

Oprawa: jak w poz. 5.

Sygn.: KUL-V-36947/5 (2004/2005).

E. - , L. - , Z. -

9. [cz. 2] [...] Katalog Rodziny Wincentyńskiej 2006/2007. Rok VI, red. Adam W. Borowski CM, Kraków [2006], Kuria Prowincjalna, Wydawnictwo Instytutu Te- ologicznego Księży Misjonarzy, $17 \mathrm{~cm}$., 216 ss. + fotografie.

Treść: jak w poz. 5 .

Uwagi: jak w poz. 5.

Oprawa: jak w poz. 5.

Sygn.: KUL-V-36947/6 (2006/2007).

E. - , L. -, Z. -

10. [cz. 2] [...] Katalog Rodziny Wincentyńskiej 2007/2008. Rok VII, [red. Adam W. Borowski CM], Kraków [2007], Kuria Prowincjalna, Wydawnictwo Instytutu Teologicznego Księży Misjonarzy, 17 cm., 224 ss. + fotografie.

Treść: jak w poz. 5.

Uwagi: jak w poz. 5.

Oprawa: jak w poz. 5.

Sygn.: KUL-V-36947/6 (2006/2007).

E. - , L. - , Z. -

\section{PALLOTYNI}

\section{Stowarzyszenie Apostolstwa Katolickie-} go (Societatis Apostolatu Catholici$\mathrm{SAC})$.

Wspólnota powstała $\mathrm{z}$ inicjatywy św. Wincentego Pallotiego w 1835 r. w Rzymie. Do Polski dotarła w 1907 r., a prowincję polską erygowano w 1935 r. Po II wojnie światowej polscy pallotyni prowadzili intensywną działalność poza granicami Polski (m. in. w Rwandzie, Brazylii). Zbiór kalendarzy i katalogów BU KUL tego zakonu dotyczy prowincji polskiej, która w 1993 r. została podzielona na dwie jednostki administracyjne $\mathrm{z}$ siedzibami w Poznaniu i Warszawie.

1. [cz. 1] Calendarium Provinciae Christi Regis SAC iussu et autoritate revmi D. Gulielmi Möhler rectoris generalis dispositum pro anno 1969, Posnaniae Varsaviae 1969, Pallottinum, 14 cm., 56 ss.

Treść: Documenta, zasadniczy zrąb kalendarza.

Uwagi: jęz. pol., łac., błędna syg. Powinno być: KUL-V 16954/1969. 
Oprawa: papier wydaw., napis, jak na str. tyt.

Sygn.: KUL-V 16954/1970.

E. -, L. -, Z. -

2. [cz. 1] Calendarium [...] pro anno 1970, Posnaniae - Varsaviae 1970, [b.w.], Pallottinum, $14 \mathrm{~cm}$., 60 ss.

Treść: jak w poz. 1.

Uwagi: jęz. pol., łac.

Oprawa: jak w poz. 1.

Sygn.: KUL-V 16954/1970.

E. - , L. - Z. -

3. [cz. 1] Calendarium [...] pro anno 1971, Posnaniae - Varsaviae 1971, [b.w.], Pallottinum, $15 \mathrm{~cm}$., 48 ss.

Treść: Uwagi praktyczne, zasadniczy zrąb kalendarza.

Uwagi: jęz. pol. (w tym częściowo kalendarz), łac.

Oprawa: brak.

Sygn.: KUL-V 16954/1971.

E.,- L. - , Z. -

4. [cz. 1] Calendarium [...] iussu et autoritate rev-mi D. Nicolai Gorman Rectoris Generalis dispositum pro anno bissextili 1972, Posnaniae - Varsaviae 1972, [b.w.], Pallottinum, 14 cm., s. 48 ss.

Treść: Uwagi praktyczne, zasadniczy zrąb kalendarza, dokumenty.

Uwagi: zmiana tytułu kalendarza w stosunku do poz. 1, jęz. pol. (w tym częściowo kalendarz), łac.

Oprawa: brak.

Sygn.: KUL-V 16954/1972.

E. -, L. - , Z. -

5. [cz. 1] Calendarium [...] pro anno 1973, Posnaniae - Varsaviae 1972, [b.w.], Pallottinum, $14 \mathrm{~cm}$., 48 ss.

Treść: jak w poz. 4 . łac.

Uwagi: jęz. pol. (w tym częściowo kalendarz),

Oprawa: papier wydaw., jednocześnie str. tyt.

Sygn.: KUL-V 16954/1973.

E. -, L. -, Z. -

6. [cz. 1] Kalendarz liturgiczny Pol- skiej Prowincji SAC na rok 1974, Poznań - Warszawa 1973, Pallottinum, [b.w.], 14 cm., 44 ss.

Treść: jak w poz. 3 .

Uwagi: zmiana tytułu kalendarza w stosunku do poz. 4, całość w jęz. pol.

Oprawa: jak w poz. 5.

Sygn.: KUL-V 16954/1974.

E. -, L. - , Z. -

7. [cz. 2] Katalog Polskiej Prowincji Stowarzyszenia Apostolstwa Katolickiego (Księża Pallotyni) [na rok 1975]. Stan w dniu 20.IX.1974 r., Warszawa 1974/75, [b.w.], D. P., 15 cm., 78, [2] ss.

Treść: władze Zgromadzenia, skład osobowy poszczególnych domów, adresy.

Uwagi: zmiana tytułu kalendarza w stosunku do poz. 6 , całość w jęz. pol.

Oprawa: papier wydaw., napis jak na str. tyt.

Sygn.: KUL V-19147/1974/75.

E. -, L. -, Z. -, W. poz. 306

8. [cz. 1] Kalendarz [...] na rok 1976, Poznań-Warszawa 1976, [b.w.], Pallottinum, $14 \mathrm{~cm} ., 44 \mathrm{ss}$.

Treść: jak w poz. 3 .

Uwagi: całość w jęz. pol.

Oprawa: jak w poz. 1.

Sygn.: KUL-V 16954/1976.

E. - , L. - , Z. -

9. [cz. 1] Kalendarz [...] na rok 1977, Poznań-Warszawa 1977, [b.w.], Pallottinum, $14 \mathrm{~cm} ., 46$ ss.

Treść:. jak w poz. 3 .

Uwagi: jak w poz. 8.

Oprawa: papier wydaw., jednocześnie str. tyt.

Sygn.: KUL-V 16954/1977.

E. -, L. -, Z. -, W. poz. 306

10. [cz. 2] Katalog [...] [na rok 1978]. Stan w dniu 01.X.1977 r., oprac. Stanisław Wojtyła SAC, Warszawa 1977, [b.w.], Druk. „Pallottinum”, 21 cm., 184 ss. + zdjęcia, mapy.

Treść: jak w poz. 7.

Uwagi: jak w poz. 8 . 
Oprawa: jak w poz. 7.

Sygn.: KUL V-19147/1977.

E. -, L. - , Z. -

11. [cz. 1] Kalendarz [...] na rok 1979, Poznań - Warszawa 1978, [b.w.], Pallottinum, $14 \mathrm{~cm} ., 48$ ss.

Treść: jak w poz. 3.

Uwagi: jak w poz. 8 .

Oprawa: papier wydaw., jednocześnie str. tyt.

Sygn.: KUL-V 16954/1979.

E. - , L. - , Z. -

12. [cz. 2] Katalog [...]. Dodatek nr 1. Stan w dniu 30.XI.1978 r., oprac. Edmund Winklarz SAC, Warszawa 1978, [b.w.], Pallottinum, $20 \mathrm{~cm}$., 40 ss.

Treść: jak w poz. 7.

Uwagi: jak w poz. 8 .

Oprawa: brak, od razu str. tyt.

Sygn.: KUL V-19147/1978. KUL V-16954/1978.

E. - , L.,- Z. -

13. [cz. 1] Kalendarz [...] na rok 1979, Poznań - Warszawa 1978, [b.w.], Pallottinum, $15 \mathrm{~cm} ., 47$ ss.

Treść: jak w poz. 3.

Uwagi: jak w poz. 8 .

Oprawa: papier wydaw., jednocześnie str. tyt.

Sygn.: KUL-V 16954/1979.

E. - , L. - , Z. -

14. [cz. 2] Katalog [...] [na rok 1980]. Dodatek nr 2 Stan w dniu 31.XII.1979 r., oprac. Edmund Winklarz SAC, Warszawa 1980, [b.w.d.], 21 cm., 46 ss.

Treść: jak w poz. 1.

Uwagi: jak w poz. 8 .

Oprawa: jak w poz. 3.

Sygn.: KUL V-19147/1979.

E. - , L. - , Z. -

15. Sygn.: KUL-V 16954/1983 - błędna sygnatura Kalendarza liturgicznego Polskich Prowincji Towarzystwa Jezusowego.

16. [cz. 1] Kalendarz [...] na rok
1986, Poznań-Warszawa 1985, [b.w.], Pallottinum, $15 \mathrm{~cm} ., 56$, [5] ss.

Treść: jak w poz. 3 .

Uwagi: jak w poz. 8 .

Oprawa: papier wydaw., jednocześnie str. tyt.

Sygn.: KUL-V 16954/1986.

E. -, L. - , Z. -

17. [cz. 1] Kalendarz [...] na rok 1988, Poznań-Warszawa 1987, Pallottinum, $15 \mathrm{~cm} ., 52$, [1] ss., [4] kk.

Treść: jak w poz. 3.

Uwagi: jak w poz. 8 .

Oprawa: papier wydaw., jednocześnie str. tyt.

Sygn.: KUL-V 16954/1988.

E. - , L. - , Z. -

18. [cz. 1] Kalendarz [...] na rok 1989, Poznań-Warszawa 1988, [b.w.], Pallottinum, $15 \mathrm{~cm}$., 58 ss., [1] k.

Treść: jak w poz. 3.

Uwagi: jak w poz. 8 .

Oprawa: papier wydaw., jednocześnie str. tyt.

Sygn.: KUL-V 16954/1989.

E. - , L. - Z. -

\section{PAULINI}

\section{Zakon Świętego Pawla Pierwszego Pu- stelnika (Ordo Sancti Primi Eremitae- OSPPE).}

Zakon wziął swój początek od eremickiej wspólnoty utworzonej w XIII w. na Węgrzech. Stąd rozprzestrzenił się przede wszystkim na teren krajów bałkańskich, Niemiec i Polski.

Do Polski paulini przybyli w 1382 r. za panowania Ludwika Węgierskiego. Pierwszy klasztor został ufundowany przez Władysława Opolczyka na Jasnej Górze w Częstochowie. Zakon bardzo szybko zaczął się rozwijać mając od początku istnienia własną prowincję niezależną od węgierskiej, z której przybyli pierwsi mnisi.

Stan ten zmienił pierwszy rozbiór Polski. Klasztory, które znalazły się pod ber- 
łem Austrii zostały częściowo skasowane już w latach 1783-86. Na ziemiach jeszcze należących do Rzeczypospolitej, ze względu na zakaz komunikacji z władzami generalnymi, papież Pius VI odzielił prowincję polską od reszty zakonu (w roku 1810 do prowincji polskiej przyłączono pozostałe klasztory galicyjskie). Kolejne kasaty jednak znosiły poszczególne klasztory, by ostatecznie po 1864 r. w Królestwie Polskim przetrwały jedynie dwa w Częstochowie - na Jasnej Górze i kościół św. Barbary. Po przekazaniu tego ostatniego w 1891 r. nowoutworzonej parafii, paulini na ziemiach polskich posiadali jedyne klasztor na Jasnej Górze i na „Skałce” w Krakowie. Druki paulinów dotyczą więc prowincji polskiej (do 1864 r.) oraz domów funkcjonujących po kasatach (1864-1918) - XIV.1.

Zakon zaczął odradzać się po odzyskaniu przez Polskę niepodległości. W 1920 r. zwołano kapitułę generalną, na której wybrano generała zakonu-XIV.2. Zakon w II Rzeczypospolitej (po 1918 r.).

\section{XIV.1. PROWINCJA POLSKA (DO 1864 R.) ORAZ DOMY FUNKCJONUJĄCE PO KASATACH (1864-1918)}

1. Sygn.: KUL V-6861A/1811 - brak.

2. [cz. 1] Directorium divini officii recitandi et missarum celebrandarum juxta rubricas generales Breviarii et Missalis Romani nec non Decreta S.R. Congregationis ad usum Ordinis S. Pauli Primi Eremitae jussu Admodü Reverendi ac Eximii in Xsto patris Hilarionis Bobrowski prioris provincialis S.T.D. editum pro Anno Domini MDCCCXI [1811] qui est post bissextilem tertius, [Częstochowa 1810], [b.w.d.], 16 cm., [76] ss., egz. interfol. [13] kk.

Treść: zasadniczy zrąb kalendarza, Decreta.

[cz. 1a] Cathalogus patrum et fratrum [...] defunctorum, s. [67-68].

[cz. 2] Catalogus officialium Congre- gationis S. Pauli Primi Eremitae sub praesidentia Reverendissimi in Christo patris Matthaei Luboienski visitatoris generalis S.T. doctoris tempore capituli electivi provinciali in Claro Monte Częstochoviensi diebus Octorbis Anno Domini 1810 celebrati dispositus, s. [69-76].

Treść: Benefactores Vivi [...], władze prowincji, skład osobowy poszczególnych domów zakonnych.

Uwagi: na str. tyt. herb Zakonu.

Oprawa: półmateriał, twarda, tłoczone zdobienia, pozłacane.

Sygn.: KUL V-6861/1811, KUL V-6861A/1811.

E. - , L.,- Z. -

3. [cz. 1] Directorium divini officii recitandi et missarum celebrandarum juxta rubricas generales Breviarii et Missalis Romani nec non Decreta S.R. Congregationis ad usum Ordinis Monachorum S. Pauli I. Ertae jussu Admodű Reverendi ac Eximii in Xto patrio [!] Andrae Czechowicz prioris provincialis S.T.D. editum pro Anno Domini MDCCCXVI [1816] qui est bissextilis, [Częstochowa 1815], [b.w.d.], 16 cm., [56] ss., egz. interfol. [7] kk.

Treść: jak w poz. 2.

[cz. 1a] Cathalogus patrum et fratrum [...] defunctorum, s. [56].

Proweniencja: „x Filip Lipinski Kaznodzieja Zurecki [?]”. \{Missa absoluta $\}$.

Uwagi: zmiana tytułu kalendarza w stosunku do poz. 2; na str. tyt. herb Zakonu, notatki prywatne gł. rachunki.

Oprawa: tektura, twarda, tłoczone zdobienia, pozłacane, ucięte rogi kart.

Sygn.: KUL V-6861A/1816.

E. - , L. -, Z. -

4. [cz. 1] Directorium divini officii recitandi et missarum celebrandarum juxta rubricas generales Breviarii et Missalis Romani nec non Decreta S.R. Congregationis in usum Congregationis S. Pauli Primi Eremitae jussu Admodum Rever. ac Eximii in Xto patris Joannis Gółkowski prioris Provincialis S.T.D. editum pro Anno Domini 
MDCCCXXIV [1824] qui est bissextilis, [Częstochowa 1823], [b.w.], Typis Claromontanis, 16 cm., [64] ss., egz. interfol. [4] $\mathrm{kk}$.

Treść: zasadniczy zrąb kalendarza, Decreta, annotatio celebrium festorum in ecclesiis caenobiorum Congreg. nostrae praeter signata, s. [30-31].

[cz. 1a] Chronologia pro clientibus Marianis, Necrologus, s. [58-64].

Treść: najważniejsze daty dotyczące obrazu Matki Boskiej Częstochowskiej, Memorabilia S. Ordinis nostri - liczba klasztorów w poszczególnych krajach, chronologia fundacji na ziemach polskich.

Uwagi: zmiana tytułu kalendarza w stosunku do poz. 3; na str. tyt. herb Zakonu oraz pieczątka (nieczytelna). Z herbem Królestwa Polskiego [?] i napisem nieczytelnym, ucięte rogi kart.

Oprawa: tektura, twarda, tłoczone zdobienia.

Sygn.: KUL V-6861A/1824.

E. - , L. s. 417, Z. -

5. [cz. 2] Cathalogus officialium et residentium patrum ac fratrum pro monasteriis destinatorum Ordinis S. Pauli 1mi Eremitae in Regno Poloniae sub praesidentia Reverendissimi ac Eximii in Christo patris Joannis Gółkowski visitatoris generalis S. T.D. tempore capituli electivi prioris provincialis in Claro Monte Częstochoviensi celebrati dispositus diebus mensis Septembris anno D. 1828, [Częstochowa 1827], [b.w.d.], $16 \mathrm{~cm} .$, [16] ss.

Treść: Benefactores vivi [...], Officiales congregationis, skład osobowy poszczególnych domów zakonnych, Patres ac fratres [...] defuncti.

Uwagi: papier czerpany, notatka ołówkiem: ,dar Sem. Duch. w Sandomierzu 1951 r."

Oprawa: brak.

Sygn.: KUL V-6861/1828.

E. -, L. s. 417 (włącznie z directorium), Z. -

6. [cz. 1] Directorium divini officii recitandi et missarum celebrandarum juxta rubricas generales Breviarii et Missalis Romani nec non Decreta S. R. Congregat. in ussum Ordinis Sancti Pauli Primi Eremitae jussu Admodum Rev. ac Eximii in Xto patris Theodori Fortuński prioris provincialis
S.T.D. editum pro Anno Domini MDCCCXXIX [1829] qui est post bissextilem primus, [Częstochowa 1828], [b.w.], Typis Claromontanis, $16 \mathrm{~cm}$., [95] ss., egz. interfol. [8] kk.

Treść: zasadniczy zrąb kalendarza, annotatio celebrium $[\ldots]$.

[cz. 1a] Memorabilia S. Ordinis nostri, s. [72-80].

[cz. 2] Cathalogus [...] dispositus diebus mensis Septembris anno D. 1828, s. [8195].

Treść: jak w poz. 2.

Uwagi: zmiana tytułu kalendarza w stosunku do poz. 4; na str. tyt. herb Zakonu, pieczątka z napisem:"Stka" i herbem Królewstwa Polskiego.

Proweniencja: „Die 10 Februarii 1829 apparuit Cracovia RP. Melchior Markiewicz hujus Directorii Professor".

Oprawa: tektura, twarda, tłoczone zdobienia, pozłacane brzegi kart.

Sygn.: KUL V-6861A/1829.

E. -, L. s. $417-418$, Z. -

7. [cz. 1] Directorium divini officii recitandi et missarum celebrandarum juxta rubricas general. Breviarii et Missalis Romani nec non Decreta S. R. Congregatio. in usum Ordinis Monchorum S. Pauli 1 Ertae jussu Admodum Rev. ac Eximii in Xto patris Philippi Lipiński prioris provincialis $\mathrm{S}$. T.D. editum pro Anno Domini MDCCCXXXVI [1836] qui est bissextilis, [Częstochowa 1835], [b.w.], Typis Claromontanis, 16 cm., [126] ss., egz. interfol. [12] kk.

Treść: Epochae notabiliores, zasadniczy zrąb kalendarza, annotatio de quibusdam ceremonii et decretis[...], Decretum [...], Notificatio celebrium festorum in eclesiis caenobiorum Ordinis nostri praeter signata, Phases lunae (zamieszczone po dodatku).

[cz. 1a] Necrologus, s. [110].

[cz. 2] Catalogus officialium et residentium patrum ac fratrum pro monasteriis destinatorum, Ordinis Sancti Pauli Primi Eremitae sub praesidentia Admodum Reverendissimi ac Eximii in Christo patris Philippi Lipiński prioris provincialis S.T.D. 
tempore capituli intermedii provincialis in Claromonte Częstochoviensi celebrati dispositus diebus Junii Anno Domini 1835, s. [113-126].

Treść: jak w poz. 2.

Proweniencja: „R.P. Cantio erga absolutionem unius Missae [....]”. (R.P. Cantius Młynarski Superior w klasztorze „Na Skałce” w Krakowie na Kazimierzu").

Uwagi: zmiana tytułu kalendarza w stosunku do poz. 6 i schematyzmu w stosunku do poz. 5 , na str. tyt. herb Zakonu.

Oprawa: tektura, twarda.

Sygn.: KUL V-6861A/1836.

E. -, L. s. 419 , Z. -

8. [cz. 1] Directorium [...] pro Anno Domini MDCCCXXXVII [1837] qui est post bissextilem primus, [Częstochowa 1836], [b.w.], Typis Claromontanis, 16 cm., [135] ss., egz. interfol. [10] kk.

Treść: Epochae notabiliores, zasadniczy zrąb kalendarza, jak w poz. 6, Decretum (m. in. Decretum S.R.C. de concessione novorum festorum Ordini [...]), Index festorum noviter a S.R. Congr. Ordini Monachorum S. Pauli I Ertae, Imperialis ac regalis palatij [!] dies festivi, modlitwy, Phases lunae.

[cz. 1a] Necrologus, s. [119-120].

[cz. 2] Catalogus officialium et residentium patrum ac fratrum pro monasteriis destinatorum, Ordinis Sancti Pauli Primi Eremitae sub praesidentia Reverendissimi ac Eximii in Christo patris Joannis Gółkowski visitatoris generalis S.T.D. tempore capituli electivi provincialis in Claromonte Częstochoviensi celebrati dispositus diebus Octobris Anno Domini 1836, s. [121135].

Treść: jak w poz. 2.

Uwagi: zmiana tytułu schematyzmu w stosunku do poz. 7; notatki, na str. tyt. herb Zakonu, pieczątka $\mathrm{z}$ herbem Królestwa Polskiego [?] i napis nieczytelny.

Oprawa: tektura, twarda.

Sygn.: KUL V-6861A/1837.

E. -, L. s. 419 , Z. -

9. [cz. 1] Directorium [...] pro Anno Domini MDCCCXXXVIII [1838] qui est post bissextilem secundus, [Częstochowa 1837], [b.w.], Typis Claromontanis, $16 \mathrm{~cm}$., [112] ss.

Treść: jak w poz. 8 .

[cz. 1a] Necrologus, s. [111-112].

Proweniencja: „Fratris Expectantis [........ Laurentii I. Kubaczek in Claro Monte 1838”.

Uwagi: notatki, na str. tyt. herb Zakonu.

Oprawa: papier, miękka.

Sygn.: KUL V-6861A/1838.

E. -, L. s. 419 , Z. -

10. [cz. 1] Directorium [...] pro Anno Domini MDCCCXXXIX [1839] qui est post bissextilem tertius, [Częstochowa 1838], [b.w.], Typis Claromontanis, 16 cm., [115] ss.

Treść: jak w poz. 8.

[cz. 1a] Necrologus, s. [115].

Uwagi: notatki słabo czytelne, na str. tyt. herb Zakonu.

Oprawa: papier, miękka, brak okładki z przodu Sygn.: KUL V-6861A/1839.

E. -, L. - 419-40 (włącznie ze schematyzmem), Z. -

11. [cz. 1] Directorium [...] pro Anno Domini MDCCCXL [1840] qui est post bissextilis et embolismales, [Częstochowa 1839], [b.w.], Typis Claromontanis, $16 \mathrm{~cm}$., [135] ss., egz. interfol. [11], [2] kk.

Treść: Epochae notabiliores, zasadniczy zrąb kalendarza, Decreta, Festa aulica [...], modlitwy w jęz. pol., Phases lunae.

[cz. 1a] Necrologu [!], s. [119].

[cz. 2] Catalogus officialium et residentium patrum ac fratrum pro monasteriis destinatorum, Ordinis Sancti Pauli Primi Eremitae sub praesidentia Reverendissimi ac Eximii in Christo patris Philippi Lipinski visitatoris generalis S.T.D. tempore capituli electivi generalis ac provincialis in Claromonte Częstochoviensi celebrati dispositus diebus mensis Septembris Anno Domini 1839, s. [121-135].

Treść: jak w poz. 2.

Uwagi: zmiana tytułu schematyzmu w stosunku 
do poz. 8; notatki, na str. tyt. herb Zakonu, pieczątka - nieczytelna.

Oprawa: tektura, twarda,

Sygn.: KUL V-6861A/1840.

E. -, L. s. 420 (tylko schematyzm), Z. -

12. [cz. 1] Directorium divini officii recitandi et missarum celebrandarum juxta rubricas general. Breviarii et Missalis Romani nec non Decreta S. R. Congregatio. in usum Ordinis Monchorum S. Pauli 1 Ertae jussu Admodum Rev. ac Eximii in Xto patris Alexii Cisowski prioris provincialis editum pro Anno Domini MDCCCXLI [1841] qui est post bissextilem et embolismalem primus, [Częstochowa 1840], [b. w.], Typis Claromontanis, 16 cm., [119] ss., egz. interfol. [12] kk.

Treść: jak w poz. 11.

[cz. 1a] Necrologus, s. [119].

Uwagi: zmiana tytułu kalendarza w stosunku do poz. 7; notatki, pieczątka z herbem Królestwa Polskiego [?] i napisem: „Groszy 45”, na str. tyt. herb Zakonu.

Oprawa: brak.

Sygn.: KUL V-6861A/1841.

E. - , L. - Z. -

13. [cz. 1] Directorium divini officii recitandi et missarum celebrandarum juxta rubricas general. Breviarii et Missalis Romani nec non Decreta S. R. Congregatio. in usum Ordinis Monchorum S. Pauli 1 Ertae jussu Admodum Rev. ac Eximii in Xto patris Alexii Cisowski prioris provincialis editum pro Anno Domini MDCCCXLII [1842] qui est post bissextilem et embolismalem secundus, [Częstochowa 1841], [b.w.], Typis Claromontanis, 16 cm., [145] ss., egz. interfol. [13] kk.

Treść: jak w poz. 11.

[cz. 1a] Primordia monasteriorum Provinciae Polon., s. [3], Series [...] Patrum generalium [...], s. [116-126], Necrologus, s. [129].

[cz. 2] Catalogus officialium et residentium patrum ac fratrum pro monasteriis destinatorum, Ordinis Sancti Pauli Primi
Eremitae sub praesidentia Admodum Reverendi ac Eximii in Christo patris Alexii Cisowski prioris provincialis tempore capituli intermedii provincialis in Claromonte Częstochoviensi celebrati dispositus diebus mensis maji Anno Domini 1841, s. [131-145].

Treść: jak w poz. 2.

Proweniencja: „V.P. Matthaeus Knefliński erga absolutionum Imo Missae Intenta [?] Recepti die 5/1 42 ".

Uwagi: zmiana tytułu kalendarza w stosunku do poz. 12 i schematyzmu w stosunku do poz. 11; notatki, na str. tyt. herb Zakonu.

Oprawa: tektura, twarda.

Sygn.: KUL V-6861A/1842.

E. - , L. - , Z. -

14. [cz. 1] Directorium divini officii recitandi et missarum celebrandarum juxta rubricas general. Breviarii et Missalis Romani nec non Decreta S. R. Congregatio. in usum Ordinis Monchorum S. Pauli 1 Ertae jussu Admodum Rev. ac Eximii in Xto patris Eustachii Hawelski prioris provincialis S.T.D. editum pro Anno Domini MDCCCXLIII [1843] qui est post bissextilem tertius et embolismalem I., [Częstochowa 1842], [b.w.], Typis Claromontanis, 16 cm., [134] ss.

Treść: jak w poz. 11.

[cz. 2] Catalogus officialium et residentium patrum ac fratrum pro monasteriis destinatorum Ordinis monachorun [!] Sancti Pauli Primi Eremitae sub praesidentia Admodum Reverendissimi ac Eximii in Christo patris Philippi Lipiński visitatoris generalis S.T.D. tempore capituli electivi provincialis in Claromonte Częstochoviensi celebrati dispositus diebus mensis Septembris anno D. 1842, s. [119-134].

Treść: jak w poz. 2.

Proweniencja: ,ad sachristiam”.

Uwagi: zmiana tytułu kalendarza i schematyzmu w stosunku do poz. 13; notatki, na str. tyt. herb Zakonu, pieczątka $\mathrm{z}$ herbem Królestwa Polskiego i napisem: „7 1/2 Копъекъ, Kopiejek 7 1/2”.

Oprawa: papier, miękka. 
Sygn.: KUL V-6861A/1843.

E. -, L. s. 420, Z. -

15. [cz. 1] Directorium divini officii recitandi et missarum celebrandarum juxta rubricas generales Breviarii et Missalis Romani in usum Ordinis Monchorum S. Pauli I. Ertae jussu Admod. Reverendi ac Eximii in Xto patris Eustachii Hawelski prioris provincialis S.T.D. editum pro Anno Domini MDCCCXLV [1845] qui est post bissextilem primus et ipse embolismalis, [Częstochowa 1844], [b.w.], Typis Claromontanis, $16 \mathrm{~cm}$. , [134] ss., [1] k.

Treść: jak w poz. 11, Instructio.

[cz. 2] Catalogus officialium et residentium patrum ac fratrum pro monasteriis destinatorum Ordinis monachorum Sti Pauli Imi Eremitae sub praesidentia Admodum Reverendi ac Eximii in Xto patris Eustachii Hawelski prioris provincialis S.T.D. tempore capituli intermedii provincialis in Claromonte Częstochoviensi celebrati dispositus diebus mensis Junii anno Dni. 1844, s. [119-134].

Treść: jak w poz. 2. ski.

Proweniencja: „Pr. Eustachius” \{??\} Hawel-

Uwagi: zmiana tytułu kalendarza i schematyzmu w stosunku do poz. 14.

Oprawa: papier, miękka.

Sygn.: KUL V-6861A/1845.

E. cz. 1, t. I, s. 181 (tylko schematyzm), L. s. 420 (tylko schematyzm), Z. -

16. [cz. 1] Directorium [...] pro Anno Domini MDCCCXLVIII [1848] qui est bissextilis et embolismalis, [Częstopchowa 1847], [b.w.], Typis Claromontanis, 16 cm., [118], 15 ss., egz. interfol. [12] kk.

Treść: jak w poz. 11, Lunationes.

[cz. 1a] Necrologus, s. [115-116].

[cz. 2] Catalogus [...] dispositus diebus 14, 15, 16 mensis Junii anno Dni. 1847, $15 \mathrm{ss}$.

Treść: jak w poz. 2.

Proweniencja: „A. RP. Eustachius Hawelski Prior Provincialis S.T.D.”.
Uwagi: notatki, na str. tyt. herb Zakonu.

Oprawa: tektura, twarda, tłoczone zdobienia, napis jak w proweniencji.

Sygn.: KUL V-6861A/1848.

E. -, L. s. 421, Z. -

17. [cz. 1] Directorium divini officii recitandi et missarum celebrandarum juxta rubricas generales Breviarii et Missalis Romani in usum Ordinis Monchorum S. Pauli I. Ertae jussu Admod. Reverendi ac Eximii in Xto patris Theodori Miernikiewicz prioris provincialis S.T.D. editum pro Anno Domini MDCCCXLIX [1849] qui est post bissextilem et embolismalem primus, [Częstochowa 1848], [b.w.], Typis Claromontanis, 16 cm., [112] ss., egz interfol. [12] kk.

Treść: jak w poz. 11.

[cz. 1a] Necrologus, s. [109-110].

Proweniencja: „RP. Eduardo Sebastiano Janowski erga absol. I. Missae Intens."

Uwagi: zmiana tytułu kalendarza w stosunku do poz. 15; notatki; pieczątka z herbem Królestwa Polskiego [?] i napisem: „Groszy 45”; na str. tyt. herb Zakonu; brak stron.

Oprawa: tektura, twarda.

Sygn.: KUL V-6861A/1849.

E. -, L. s. 421 , Z. -

18. [cz. 1] Directorium divini officii recitandi et missarum celebrandarum juxta rubricas generales Breviarii et Missalis Romani in usum Ordinis Monchorum S. Pauli I. Ertae jussu Admod. Reverendi ac Eximii in Xto patris Theodori Miernikiewicz prioris provincialis S.T.D. editum pro Anno Domini MDCCCLI [1851] qui est post bissextilem et embolismalem tertius ac embolismalis, [Częstochowa 1850], [b.w.], Typis Claromontanis, $16 \mathrm{~cm} .$, [134] ss., egz. interfol. [12] kk.

Treść: zasadniczy zrąb kalendarza, Notificatio [...], Decreta [...], Imperialis [...] dies festivi, modlitwy.

[cz. 1a] Necrologus, s. [131-132].

Proweniencja: „RP. Mariano Suppriori erga absol. I. Missae Intens."

Uwagi: zmiana tytułu kalendarza w stosunku do 
poz. 17; notatki, na str. tyt. herb Zakonu, pieczątka z herbem Królestwa Polskiego i napisem: „7 1/2 Копъекъ, Kopiejek 7 1/2”, na końcu kalendarza napis: „Opera patris Lucae Grządzielski Vicarii Prvae Annus XXII".

Oprawa: tektura, twarda, bogate zdobienia, złocone brzegi kart.

Sygn.: KUL V-6861A/1851.

E. -, L. s. 421 , Z. -

19. [cz. 1] Directorium divini officii recitandi et missarum celebrandarum juxta rubricas generales Breviarii et Missalis Romani in usum Ordinis Monchorum S. Pauli I. Ertae jussu Admod. Reverendi ac Eximii in Xto patris Alexandri Zięba prioris provincialis S.T.D. editum pro Anno Domini [1852], [b.m. 1851], [b.w.d.], 16 cm., [120] ss., egz interfol. [12] kk. + wklejka.

Treść: jak w poz. 18.

[cz. 1a] Necrologus, s. [119-120].

Uwagi: zmiana tytułu kalendarza w stosunku do poz. 18; na końcu kalendarza napis: „Opera P. L. Grządzielski Vic. Prvae An. 23”, notatki, na str. tyt. herb Zakonu, ucięty róg katry tytułowej, Lunationes - wklejka.

Oprawa: papier, miękka.

Sygn.: KUL V-6861A/1852.

E. -, L. S. 421-422, Z. -

20. [cz. 1] Directorium divini officii recitandi et missarum celebrandarum juxta rubricas generales Breviarii et Missalis Romani in usum Monchorum Ord. S. Pauli I. Ertae jussu Admodum Reveren. ac Eximii in Xto patris Zięba prioris Provincialis S. T.D. editum pro anno 1853, [Częstochowa 1852], [b.w.], Typis Clari Montis Częstochoviensis, $16 \mathrm{~cm}$., [134] ss.

Treść: zasadniczy zrąb kalendarza, Notificatio, Decreta [...], Imperialis ac regularis palatii dies festivi, (tab): in Solemnioribus festis palatii imperialis hymnus, Versus [...].

[cz. 2] Catalogus officialium ac residentium patrum ac fratrum pro monasteriis destinatorum Ordinis Monachorum S. Pauli I. Eremitae pro Anno Domini 1853, s. [125-134].
Treść: Officiales Ordinis, skład osobowy poszczególnych domów zakonnych, Defuncti [18501852].

Uwagi: tytuł kalendarza w stosunku do poz. 19 i schematyzmu w stosunku do poz. 15; Tabella ortus $[\ldots]$, Lunationes [...].

Oprawa: brak.

Sygn.: KUL V-6861A/1853. KUL V-6861/1853.

$$
\text { E. }- \text {, L. }-, \text { Z. - }
$$

21. [cz. 1] Directorium divini officii recitandi et missarum celebrandarum juxta rubricas generales Breviarii et Missalis Romani in usum Monachorum Ord. S. Pauli I. Eremitae authoritate Admodum Reverendi ac Eximii in Xto patris Lucae Grządzielski prioris provincialis S.T.D. editum pro anno 1855 qui est post bisextilem III ac embolismal. II, [Częstochowa 1854], [b.w.], Typis Claromontanis, $16 \mathrm{~cm}$., [111] ss., egz. interfol. [9] kk.

Treść: jak w poz. 18.

Uwagi: zmiana tytułu kalendarza w stosunku do poz. 20; na końcu kalendarza napis: „Opera patris Lucae Grządzielski Priori Provincialis Ordinis Monachorum S. Pauli I Eremiatae Annus XXVI"; Tabella ortus [...], Lunationes [...].

Oprawa: papier, miękka.

Sygn.: KUL V-6861A/1855.

E. -, L. s. 422 , Z. -

22. [cz. 1] Directorium divini officii recitandi et missarum celebrandarum juxta rubricas generales Breviarii et Missalis Romani in usum Monchorum Ord. S. Pauli I. Ertae authoritate Admodum Rever. ac Eximii in Xto patris Lucae Grządzielski prioris provincialis S.T.D. editum pro $\mathbf{1 8 5 6}$ anno bissextili, [Częstochowa 1855], [b.w.], Typis Claro Montanis, 16 cm., [126] ss., egz interfol. [12] kk.

Treść: jak w poz. 18, Observationes circa functiones [...].

[cz. 2] Catalogus [...] pro Anno Domini 1856, s. [117-126].

Treść: jak w poz. 20.

Proweniencja: „Rmi Ptri Bernardo Rzepczyń- 
ski praedicatori erga absol[utionem] [?] 1. Missae Intent[ionem] [?]"dalej nieczytelne.

Uwagi: zmiana tytułu kalendarza w stosunku do poz. 21, notatki, na str. tyt. herb Zakonu.

Oprawa: tektura, twarda, tłoczone zdobienia.

Sygn.: KUL V-6861A/1856.

E. -, L. s. 422 (tylko schematyzm), Z. -

23. [cz. 1] Directorium divini officii recitandi et missarum celebrandarum juxta rubricas generales Breviarii et Missalis Romani in usum Monchorum Ord. S. Pauli I. Ertae authoritate Admodum Rever. ac Eximii in Xto patris Matthaei Kneflinski prioris provincialis S.T.D. editum pro $\mathbf{1 8 5 8}$ anno qui est post bissextilem et embolismalem II, [Częstochowa 1857], [b.w.], Typis Claro Montanis, $16 \mathrm{~cm}$., [140] ss., egz. interfol. [11] kk. + wklejka.

Treść: jak w poz. 18.

[cz. 2] Catalogus patrum ac fratrum Ordinis Monachorum Sancti Pauli Primi Eremitae tempore capituli electivi provincialis anno 1857 in Claro Monte Częstochoviensi celebrati per monasteria destinatorum, cui scitu necessaria adnexa sunt, Częstochoviensis, Typis Clari Montis, s. [129-140].

Treść:jak w poz. 20, krótka historia domów zakonnych.

Proweniencja: A.R.P. Theodorus Miernikiewicz S.T.D. exprov. Pro. ac Mag. Nov.”

Uwagi: zmiana tytułu kalendarza w stosunku do poz. 22 i schematyzmu w stosunku do poz. 20; notatki, na stronie tytułowej pieczątka z herbem Królestwa Polskiego [?] i napisem: „7 1/2 Копъекъ, na str. tyt. herb Zakonu., na końcu kalendarza napis: „Opera P. Lucae Grządzielski Ex Provincialis Annus XXVIII”, na ostatniej stronie m. in. napis: „ARP Isidorius Ordon Pater Provinciae".

Oprawa: tektura, twarda, tłoczone zdobienia.

Sygn.: KUL V-6861A/1858.

E. -, L. s. 422 , Z. -

24. [cz. 1] Directorium divini officii recitandi et missarum celebrandarum juxta rubricas generales Breviarii et Missalis Romani in usum Monchorum Ord. S. Pauli I.
Ertae authoritate Admodum Rever. ac Eximii in Xto patris Matthaei Kneflinski prioris provincialis S.T.D. editum pro anno Dni 1859 qui est post bissextilem III et embolismalem I, [Częstochowa 1858], [b.w.], Typis Claromontanis, 16 cm., [124] ss., egz interfol. [11] kk.

Treść: jak w poz. 11.

Uwagi: zmiana tytułu kalendarza w stosunku do poz. 23; na str. tyt. herb Zakonu, na końcu kalendarza napis: „Opera P. Lucae Grządzielski Ex Provincialis Annus XXIX".

Oprawa: tektura, twarda.

Sygn.: KUL V-6861A/1859.

E. -, L. s. 422 , Z. -

25. [cz. 2] Catalogus officialium et residentium patrum ac fratrum pro monasteriis destinatorum, Ordinis Monachorum Sancti Pauli Imi. Eremitae sub praesidentia Admodum Reverendi ac Eximii in Xto patris Matthaei Kneflinski prioris provincialis S.T.D. tempore capituli intermedii provincialis in Claromonte Częstochoviensi celebrati dispositus diebus mensis Maii anno Dm 1859, [Częstochowa 1858], [b. w.d.], $16 \mathrm{~cm} ., 9$, [2] ss.

Treść: jak w poz. 5 .

Uwagi: zmiana tytułu schematyzmu w stosunku do poz. 23.

Oprawa: papier, miękka.

Sygn.: KUL V-6861/1859.

E. - , L. - Z. -

26. [cz. 1] Directorium divini officii recitandi et missarum celebrandarum juxta rubricas generales Breviarii et Missalis Romani in usum Monchorum Ord. S. Pauli I. Ertae authoritate Admodum Rever. ac Eximii in Xto patris Matthaei Kneflinski prioris provincialis S.T.D. editum pro anno Dni 1860 qui est post bissextilis post embolismalem II, [Częstochowa 1859], [b.w.], Typis Claromontanis, $16 \mathrm{~cm}$., [121] ss.

Treść: zasadniczy zrąb kalendarza, Notificatio [...], Decreta [...],

Proweniencja: ,Ad sacristiam,,.

Uwagi: zmiana tytułu kalendarza w stosunku do 
poz. 25; na str. tyt. herb Zakonu, na końcu kalendarza napis: „Opera P. Lucae Grządzielski Ex Provincialis Annus XXX".

Oprawa: tektura, twarda.

Sygn.: KUL V-6861A/1860.

E. -, L. s. 422 , Z. -

27. [cz. 2] Catalogus officialium et residentium patrum ac fratrum pro monasteriis destinatorum, Ordinis Monachorum Sancti Pauli Imi. Eremitae sub praesidentia Reverendissimi ac Eximii in Xto. patris Matthaei Knefliński visitatoris generalis S.T.D. tempore capituli electivi generalis ac provincialis in Claromonte Częstochoviensi celebrati dispositus diebus mensis Octobris anno Dni 1860, [Częstochowa 1859], [b.w.d.], $16 \mathrm{~cm} ., 11$ ss.

Treść: jak w poz. 2, Necrologus (1858 -1860).

Uwagi: zmiana tytułu schematyzmu w stosunku do poz. 25.

Oprawa: papier, miękka.

Sygn.: KUL V-6861/1860.

E. - , L. - Z. -

28. [cz. 1] Directorium divini officii recitandi et missarum celebrandarum juxta rubricas generales Breviarii et Missalis Romani in usum Monchorum Ord. S. Pauli I. Ertae authoritate Admodum Rever. ac Eximii in Xto patris Juliani Nowakowski prioris provincialis editum pro anno Dni 1861 qui est post bissextilem I ipse vero embolismalis, [Czestochowa 1860], [b.w.], Typis Claromontanis, 16 cm., [122] ss., egz interfol. [11] kk.

Treść: jak w poz. 26.

Uwagi: zmiana tytułu kalendarza w stosunku do poz. 26; na str. tyt. herb Zakonu, na końcu kalendarza napis: „Opera P. Lucae Grządzielski Ex Provincialis Annus XXIX”.

Oprawa: tektura, twarda, ozdobne tłoczenia.

Sygn.: KUL V-6861A/1861.

E. - , L. - , Z. -

29. [cz. 1] Directorium divini officii recitandi et missarum celebrandarum juxta rubricas generales Breviarii et Missalis Ro- mani in usum Ordinis Monchorum S. Pauli I. Ertae authoritate Admodum Reverendi ac Eximii in Xto patris Petri Kubarski gubernantis provincialis editum pro Anno Domini 1862 qui est post bissextilem I ipse vero embolismalis, [Częstochowa 1861], [b.w.], Typis Claromontanis, $17 \mathrm{~cm} .$, [70] ss., egz. interfol. [10] kk. + wklejka.

Treść: jak w poz. 26.

Uwagi: zmiana tytułu kalendarza w sotusnku do poz. 28; na str. tyt. herb Zakonu, na końcu kalendarza napis: „Opera P. Lucae Grządzielski Ex Provincialis Annus XXXII".

Oprawa: papier wydaw., napis: „Directorium in usum Monacorum Ordinis S. Pauli I. Eremiatae”, rycina Jasnej Góry, z tyłu adres wydawniczy.

Sygn.: KUL V-6861A/1862.

E. -, L. s. 422-423, Z. -

30. Sygn. KUL V-6861/1866 - brak.

31. [cz. 1] Directorium divini officii pro 1870 ad usum Monachorum Ordinis S. Pauli I. Eremitae in Rupella ad Cracoviam, Koenigshuttensis [1869], [b.w.], Typis Karoli Miarcae, $16 \mathrm{~cm} ., 38, \mathrm{~V}$, [2] ss.

Treść: zasadniczy zrąb kalendarza, Adnotatniones.

[cz. 2] Catalogus patrum ac fratrum Ordinis Monachorum S. Pauli 1. Eremiatae in Regno Poloniae morantium proesertim in sequentibus locis, Ss. V.

Treść: skład osobowy poszczególnych domów zakonnych.

Uwagi: zmiana tytułu kalendarza w stosunku do poz. 29 i schematyzmu w stosunku do poz. 27.

Oprawa: brak.

Sygn.: KUL V-6861A/1870. KUL V-6861/1870 - brak.

E. - , L. - , Z. -

32. [cz. 1] Directorium officii divini juxta rubricas Breviarii et Missalis Romani ad usum Monachorum Ordinis S. Pauli I. Ertae pro Anno Domini 1873, Cracoviae [1872], [b.w.], Typis Leonis Paszkowski, $18 \mathrm{~cm}$., [49] ss. 
Treść: jak w poz. 26.

[cz. 2] Catalogus [...], s. [45-49].

Treść: skład osobowy poszczególnych domów zakonnych, Necrologus.

Uwagi: zmiana tytułu kalendarza w stosunku do poz. 31.

\section{Oprawa: brak.}

Sygn.: KUL V-6861A/1873.

E. -, L. s. 423, Z. -

33. [cz. 2] Schematismus religiosi Ordinis S. Pauli Primi Eremitae olim in Hungaria, ubi nactus incunabula, celeberrimi; nunc temporum iniuriis in Imperio Austriae et Polonia Russica, ad duo monasteria restrici. Sedi Apostolicae immediate subiecti ad annum a Christo nato MDCCCLXXVIII [1878], Cracoviae 1878, sumptibus PP. Paulinorum, E Typographia Ephemeridum „Czas”, provisore Josepho Łakociński, $18 \mathrm{~cm} ., 24$ ss.

Treść: jak w poz. 2, aktualny pontyfikat papieża; Praesidentis generalis in Imperio Austriae; Tabella synoptico-chronologica, Index personarum (tab.); Appendix de claustro S. Crucis in Hungaria; Conspectus ven. confraternitatis [...] in Imperio.

Uwagi: zmiana tytułu schematyzmu w stosunku do poz. 31, na okładce errata,.

Oprawa: papier, miękka, napis jak na str. tyt. (bez sumptibus [...]), wizerunek Kielicha i Hostii.

Sygn.: KUL V-6861/1878.

E. -, L. S. 424-425, Z. -

34. [cz. 2] Schematismus [...]. Ad annum a Christo nato MDCCCLXXIX [1879], Cracoviae 1879, [sumptibus PP. Paulinorum], E Typographia Ephemeridum „Czas”, provisore Josepho Łakociński, 18 cm., 24 ss.

Treść: jak w poz. 5.

Uwagi: uzupełnienie tytułu z treści schematyzmu.

Oprawa: jak w poz. 32.

Sygn.: KUL V-6861/1879.

E. cz. 1, t. VII, s. 117, L. -, Z.-

35. [cz. 1] Directorium divini officii recitandi et missarum celebrandarum juxta rubricas generales Breviarii ac Missalis Romani pro Anno Domini 1880 qui est bissextilis de mandato Admodum Reverendi patris Tiburtii Kneża praesidentis generalis ordinatum ad usum Monachorum Ordinis S. Pauli primi Eremitae, Cracoviae 1880, [b.w.], Typis Universitatis Jagellonicae, provisore Ignatio Stelcel, $18 \mathrm{~cm}$., $45 \mathrm{ss}$.

Treść: zasadniczy zrąb kalendarza, Festa papalia [...], Notificanda.

[cz. 2] Subnexus Catalogus, s. 40-45.

Treść: skład osobowy domu zakonnego w Krakowie, Series et status personalis [...] in Regno Poloniae.

Uwagi: zmiana tytułu kalendarza w stosunku do poz. 32, na końcu kalendarza napis: „Opera P. Floriani Kurdyś".

Oprawa: papier, miękka, napis jak na str. tyt. oprócz r. wyd.

Sygn.: KUL V-6861/1880. KUL V-6861A/1880.

E. - , L.,- Z. -

36. [cz. 1] Directorium officii divini rubricis Breviarii ac Missalis Romani a S. R. Congregatione die 8 Julii 1880 Romae approbatis conformatum. in usum patrum Ordinis Religiosi S. Pauli Pr. Eremitae, auctoritate et mandato Admodum Reverendi patris Tiburtii Kneża praesidentis generalis editum pro anno a Christo nato MDCCCLXXXI [1881], Cracoviae [1880], [b.w.], Typis Regiae Univesitatis Jagellonicae sub directione Ignatii Stelcel, 48 ss.

Treść: zasadniczy zrąb kalendarza.

[cz. 2] Appendix, s. 46-48.

Treść: skład osobowy domu zakonnego w Krakowie, dobrodzeje zakonu, Defuncti, Errores typi.

Uwagi: zmiana tytułu kalendarza w stosunku do poz. 35.

Oprawa: papier, miękka, napis odręczny: „Ordinis S. Pauli I Erem. 1881".

Sygn.: KUL V-6861/1881. KUL V-6861A/1881 - okładka bez napi-

su.

E. - , L. - Z. - 
37. [cz. 1] Directorium officii divini in usum Ordinis S. Pauli Pr. Eremitae editum pro anno a Chr. nato MDCCCLXXXII [1882], Cracoviae 1882, sumptibus Patrum Paulinorum, E Typographia Związkowa sub directione A. Szyjewski, 18 cm., 28 ss., [1] k.

Treść: jak w poz. 36 .

[cz. 2] Appendix, s. [27-28].

Treść: jak w poz. 36, Adnotationes, bez Errores typi.

Uwagi: zmiana tytułu kalendarza w stosunku do poz. 36.

Oprawa: brak.

Sygn.: KUL V-6861/1882.

KUL V-6861A/1882.

E. - , L. - , Z. -

38. [cz. 1] Directorium officii divini in usum monachorum Ordinis S. Pauli I. Eremitae, editum pro anno a Chr. nato MDCCCLXXXIII [1883]. Juxta calendarium perpetuum a Sacra Congregatione $\mathrm{Ri}$ tuum approbatum die 8 Julii 1880, Cracoviae 1883, sumptibus Patrum Paulinorum, in Typographia Związkowa, sub directione A. Szyjewski, 20 cm., 27 ss.

Treść: jak w poz. 36.

[cz. 2] Appendix, s. [26-27].

Treść: skład osobowy domu zakonnego w Krakowie, dobrodzeje zakonu, Defuncti.

Proweniencja: napis atramentem na str. tyt.: „X. Zygmunt Wołek”.

Uwagi: zmiana tytułu kalendarza w stosunku do poz. 37.

Oprawa: brak.

Sygn.: KUL V-6861A/1883. KUL V-6861/1883.

E. - , L. - , Z. -

39. Sygn.: KUL V-6861/1884 - brak.

40. [cz. 1] Directorium [...] pro anno MDCCCLXXXV [1885] [...], Cracoviae 1884, sumptibus Patrum Paulinorum, in Typographia Związkowa, sub directione A. Szyjewski, 18 cm., 32 ss.

Treść: jak w poz. 36. [cz. 2] Appendix, s. 30-32.

Treść: jak w poz. 38 .

Uwagi: na końcu kalendarza inicjały: „P[ater] F[loriani] K[urdyś]"; błędna sygn. jest - KUL V6861A/1884, powinno być: KUL V-6861A/1885.

Oprawa: brak.

Sygn.: KUL V-6861A/1884. KUL V-6861A/1885.

E. - , L. - Z. -

41. [cz. 1] Directorium [...] pro anno MDCCCLXXXVI [1886] [...], Cracoviae 1886, sumptibus Patrum Paulinorum in Typographia Związkowa sub directione A. Szyjewski, 18 cm., 33 ss.

Treść: jak w poz. 36, Adnotatio.

[cz. 2] Appendix, s. 32-33.

Treść: jak w poz. 38, bez Defuncti.

Uwagi: na końcu kalendarza inicjały: „P[ater] F[loriani] K[urdyś]”".

Oprawa: brak.

Sygn.: KUL V-6861/1886. KUL V-6861A/1886.

E. - , L. - Z. -

42. [cz. 1] Directorium divini Officii recitandi et missarum celebrandarum juxta rubricas generales Breviarii et Missalis Romani nec non Decreta S.R. Congregationis in usum Monachorum Ordinis S. Pauli I. Eremitae, pro anno MDCCCLXXXVII [1887], Cracoviae 1887, sumptibus Patrum Paulinorum, in Typographia Związkowa sub directione A. Szyjewski, 18 cm., 40 ss.

Treść: zasadniczy zrąb kalendarza, Dies festivi papales, episcopales, Festa aulica, Notationes.

[cz. 2] Status personalis Ordinis S. Pauli Primi Eremiatae, s. 39-40.

Treść: jak w poz. 38.

Proweniencja: „R[nio?] p. Com. Ord. S. Augustini ad S. Catharinam".

Uwagi: zmiana tytułu kalendarza w stosunku do poz. 38; na końcu kalendarza inicjały: „P[ater] F[loriani] K[urdyś]”".

Oprawa: brak.

Sygn.: KUL V-6861A/1887.

E. - , L. - Z. - 
43. [cz. 1] Ordo divini officii sacrique celebrandi in usum Monachorum Ordinis S. Pauli I. Eremitae pro anno MDCCCLXXXVIII [1888] qui est bissextilis juxta calendarium perpetuum a S.C.R. die 8 Julii 1880 approbatum, Cracoviae 1887, sumptibus Patrum Paulinorum, in Typographia Związkowa sub directione A. Szyjewski, $18 \mathrm{~cm} ., 37 \mathrm{ss} .$, [1] k.

Treść: zasadniczy zrąb kalendarza, Dies festivi papales $[\ldots]$.

[cz. 2] Status personalis [...], s. 3637.

Treść: jak w poz. 38.

Uwagi: zmiana tytułu kalendarza w stosunku do poz. 42; na końcu kalendarza inicjały: „P[ater] F[loriani] K[urdyś]".

Oprawa: brak okładki z przodu.

Sygn.: KUL V-6861A/1888.

E. - , L. - , Z. -

44. [cz. 1] Ordo [...] pro anno MDCCCLXXXIX [1889] iuxta calendarium [...], [Cracoviae 1888, sumptibus Patrum Paulinorum, in Typographia Związkowa sub directione A. Szyjewski], 17 cm., 37 ss., [1] $\mathrm{k}$.

Treść: jak w poz. 43. 37.

[cz. 2] Status personalis [...], s. 34-

Treść: jak w poz. 38 .

Uwagi: zmiana tytułu kalendarza w stosunku do poz. 43; na końcu kalendarza inicjały: „P[ater] F[loriani] K[urdyś]".

Oprawa: brak.

Sygn.: KUL V-6861A/1889.

KUL V-6861/1889.

E. - , L. - , Z. -

45. [cz. 1] Ordo [...] pro anno MDCCCLXXXX [1890] [...], Cracoviae 1890, sumptibus Patrum Paulinorum, in Typographia Związkowa, sub directione A. Szyjewski, $18 \mathrm{~cm} ., 31 \mathrm{ss}$.

Treść: jak w poz. 36.

Uwagi: na końcu kalendarza inicjały: „P[ater] F[loriani] K[urdyś]".

Oprawa: papier, miękka, wtórna.
Sygn.: KUL V-6861A/1890.

E. - , L. - , Z. -

46. [cz. 2] Schematismus patrum ac fratrum Sacri Candidique Ordinis S. Pauli I. Eremitae [1890], Cracoviae 1890, sumptibus Patrum Paulinorum, in Typographia Związkowa sub directione A. Szyjewski, 18 cm., 14 ss., [1] k.

Treść: kalendarium zgromadzenia, Status Personalis, Benefactores ac Confratres Ordinis.

Uwagi: zmiana tytułu schematyzmu w stosunku do poz. 33; datacja ustalona na podstawie treści schematyzmu (s. 10).

Oprawa: papier, miękka.

Sygn.: KUL V-6861/1890.

E.,- L.,- Z. -

47. [cz. 1] Ordo [...] pro anno MDCCCLXXXXI [1891] [...], Cracoviae 1890, sumptibus Patrum Paulinorum, in Typographia Związkowa, sub directione A. Szyjewski, 19 cm., 32 ss.

Treść: jak w poz. 35 .

Uwagi: na końcu kalendarza inicjały: „P[ater] F[loriani] K[urdyśs]".

Oprawa: papier, miękka.

Sygn.: KUL V-6861A/1891.

E. - , L. - , Z. -

48. [cz. 2] Schematismus [...] [1891], Cracoviae 1890, sumptibus Patrum Paulinorum, in Typographia Związkowa sub directione A. Szyjewski, 19 cm., 14 ss., [1] $\mathrm{k}$.

Treść: jak w poz. 38.

Proweniencja: napis odręczny atramentem na okładce, trudne od odczytania: "A. R..... patri Pio Mianowski Conventus Cracoviensis Custodi Observantissimo [?]".

Uwagi: datacja ustalona na podstawie treści schematyzmu (s. 8).

Oprawa: papier, miękka.

Sygn.: KUL V-6861/1890/91.

E.,- L. - , Z. -

49. [cz. 1] Ordo [...] pro anno MDCCCLXXXXII [1892] qui est bissextilis juxta 
[...], Cracoviae 1891, sumptibus Patrum Paulinorum, in Typographia Związkowa, sub directione A. Szyjewski, 19 cm., 32 ss.

Treść: jak w poz. 36.

[cz. 1a] Defuncti, s. 32.

Uwagi: zmiana tytułu kalendarza w stosunku do poz. 44; na końcu kalendarza napis: „Opera P[ater] F[loriani] K[urdyś]".

Oprawa: papier, miękka, wtórna.

Sygn.: KUL V-6861A/1892.

E. - , L. - Z. -

50. [cz. 1] Ordo [...] pro anno MDCCCLXXXXIII [1893], Cracoviae 1892, sumptibus Patrum Paulinorum, in Typographia Związkowa, sub directione A. Szyjewski, 18 cm., 32 ss., egz. interfol. [15] kk.

Treść: jak w poz. 36.

[cz. 1a] Defuncti, s. 32.

Uwagi: notatki, na str. tyt. herb Zakonu, na końcu kalendarza napis: „Opera P[ater] T [Floriani] K[urdyś]”, błędny inicjał imienia.

Oprawa: tektura, półskórek, twarda, wtórna.

Sygn.: KUL V-6861A/1893.

E. - , L. - , Z. -

51. [cz. 1] Ordo divini officii sacrique celebrandi in usum Monachorum Ordinis S. Pauli I. Eremitae pro anno 1894 ad normam kalendarii perpetui a S.C.R. die 8 Julii approbati, Cracoviae 1893, sumptibus Patrum Paulinorum, in Typographia Związkowa sub directione A. Szyjewski, $18 \mathrm{~cm}$, 36 ss.

Treść: jak w poz. 36.

Uwagi: zmiana tytułu kalendarza zmiana tytułu schematyzmu w stosunku do poz. 43 ; na str. tyt. herb Zakonu, na końcu kalendarza napis: „Opera P[ater] F[loriani] K[urdyś]" (s. 36).

Oprawa: papier, miękka, wtórna.

Sygn.: KUL V-6861A/1894.

E. -, L. s. 423 , Z. -

52. [cz. 1] Ordo divini officii sacrique celebrandi in usum Monachorum Ordinis S. Pauli I. Eremitae pro anno 1895, Cracoviae 1894, sumptibus Patrum Paulinorum,
Typis V1. L. Anczyc et Comp., provisore J. Gadowski, 19 cm., 63 ss.

Treść:jak w poz. 36, Nota. 63.

[cz. 2]. Status personalis [...], s. 58-

Uwagi: zmiana tytułu kalendarza w stosunku do poz. 51 i schematyzmu w stosunku do poz. 46; na str. tyt. herb Zakonu, na końcu kalendarza napis: „Opera $\mathrm{P}$ [ater] M[arianus] P[iotrowski]'[??].

Oprawa: papier, miękka, wtórna.

Sygn.: KUL V-6861A/1895.

E. -, L. s. 423, Z. -

53. Sygn.: KUL V-6861A/1897 brak.

54. [cz. 1] Ordo [...] pro anno 1898, Cracoviae 1898, sumptibus Patrum Paulinorum, Typis „Drukarnia Związkowa” sub directione A. Szyjewski, 19 cm., 63 ss.

Treść: jak w poz. 36.

Uwagi: na str. tyt. herb Zakonu, na końcu kalendarza napis: „Opera P[ater] F[lorianus] K[urdyś]”.

Oprawa: papier wydaw., miękka, napis jak na str. tyt., z tyłu brak oprawy.

Sygn.: KUL V-6861A/1898.

E. - , L. -, Z. -

55. [cz. 1] Ordo [...] pro anno 1899, Cracoviae 1899, sumptibus Patrum Paulinorum, Typis „Drukarnia Związkowa” sub directione A. Szyjewski, 19 cm., 70 ss., [1] $\mathrm{k}$.

Treść: jak w poz. 36.

[cz. 2] Schematismus patrum ac fratrum Ordnis S. Pauli I. Eremiate pro anno 1899, s. [64-70].

Treść: jak w poz. 38 .

Uwagi: zmiana tytułu schematyzmu w stosunku do poz. 46; na str. tyt. herb Zakonu, na końcu kalendarza napis: „Opera F[ater] L[eo] M[akarski] [?] lub L[udovicus] M[uszyński]”.

Oprawa: papier wydaw., miękka, napis jak na str. tyt.

Sygn.: KUL V-6861A/1899.

E. - , L. - Z. - 
56. [cz. 1] Calendarium ad usum monachorum Ordinis S. Pauli Primi Eremitae custodum Basilicae Claromontanae pro re divina horisque canonicis rite persolvendis Anno Domini comuni MCMXIII [1913] Pascha occurrente die 23 Martii, Wladislviae [1912], sumptibus Patrum Paulinorum, Typis Officianae Dioecesanae, 17 cm., 119 ss.

Treść: Phases lunae, Dies festivi papales, episcopales, Tabula temporaria, Praenotanda, Ratio divini officii recitando juxta novum Psalterium [...], Adnotatniones, zasadniczy zrąb kalendarza,Dies festivi imperialis (w tym w jęz ros.), modlitwy $9 \mathrm{w}$ jęz. łac., ros. i pol.)

[cz. 2] Schematismus Ordnis S. Pauli I. Eremiate, s. 114-119.

Treść: historia poszczególnych domów zakonnych, skład osobowy poszczególnych domów zakonnych.

Uwagi: zmiana tytułu kalendarza w stosunku do poz. 52 i schematyzmu w stosunku do poz. 55.

Oprawa: tektura, twarda.

Sygn.: KUL V-6861A/1913.

E. -, L. s. 423, Z. -

14. KUL V-6861/1913 - brak.

\section{XIV.2. ZAKON W II RZECZYPOSPOLITEJ (po 1918 r.)}

1. [cz. 1] Ordo divini officii recitandi sacrique peragendi juxta kalendarium Ordinis S. Pauli I. Er. cum catalogo patrum ac fratrum eiusdem Ordinis pro Anno Domini 1934, [Częstochowa 1833], [b.w.], Drukarnia T. Nagłowskiego i S-ki, 18 cm., 64 ss.

Treść: zasadniczy zrąb kalendarza.

[cz. 2] Catalogus officialium ac residentium patrum ac fratrum pro monasteriis destinatorum Ordinis Monachorum Sancti Pauli I. Er. auctoritate Admondum Reverendi patris Pii Przezdziecki prioris generalis concinnatus in Claro Monte Częstochoviensi pro anno Dni 1934, s. 58-64.

Treść: skład osobowy poszczególnych domów zakonnych, necrologus.
Oprawa: papier, półmiękka, oryginalna.

Sygn.: KUL V-6861/1934, KUL V6861A/1934.

E. -, L. s. $423-424$, Z. -

2. [cz. 1] Ordo [...] pro Anno Domini 1935, Częstochowa [1934], Nakładem O.O. Paulinów z Jasnej Góry, Druk. T. Nagłowski i S-ka, 17 cm., 65 ss.

Treść: zasadniczy zrąb kalendarza, krótki biogram papieża oraz władz zwierzchnich zakonu.

[cz. 2] Catalogus [...] pro anno Dni 1935, s. 57-65.

Treść: skład osobowy domów zakonnych w tym w Rzymie i na Węgrzech.

Uwagi: tytuł schematyzmu jak w poz. 1 ze zmianą,$-[\ldots]$. auctoritate patris Pii Przezdziecki prioris Generalis $[\ldots]$ ".

Oprawa: papier, półmiękka, oryginalna.

Sygn.: KUL V-6861/1935, KUL V6861A/1935.

E. -, L. s. 424 , Z. -

3. [cz. 1] Ordo [...] pro Anno Domini 1936, Częstochowa [1935], Nakładen [!] O.O. Paulinów z Jasnej Góry, Druk. T. Nagłowski i S-ka, 17 cm., 60 ss.

Treść: jak w poz. 2.

[cz. 2] Catalogus officialium ac residentium patrum ac fratrum pro monasteriis destinatorum Ordinis Monachorum Sancti Pauli I. Er. auctoritate Admod. Rev. patris Pii Przezdziecki prioris generalis concinnatus in Claro Monte Częstochoviensi pro anno Dni 1936, s. 53-60.

Treść: jak w poz. 2.

Uwagi: tytuł schematyzmu w stosunku do poz. 1.

Sygn.: KUL V-6861A/1936.

E. -, L. s. 424 , Z. -

4. [cz. 1] Ordo [...] pro Anno Domini 1937, Częstochowa [1936], nakładem O.O. Paulinów z Jasnej Góry, Druk. T. Nagłowski i S-ka, 16 cm., 64 ss.

Treść: jak w poz. 2.

[cz. 2] Catalogus [...] pro anno D-ni 1937, s. 57-64. 
Treść: jak w poz. 2.

Oprawa: jak w poz. 2.

Sygn.: KUL V-6861A/1937.

E. -, L. s. 424, Z. -

5. [cz. 1] Ordo [...] pro Anno Domini 1938, Częstochowa [1937], nakładem O.O. Paulinów z Jasnej Góry, Druk. T. Nagłowski i S-ka, 16 cm., 72 ss.

Treść: jak w poz. 2.

[cz. 2] Catalogus [...] pro anno D-ni 1938, s. 63-72.

Treść: skład osobowy domów zakonnych w tym w Rzymie i na Węgrzech, necrologus, napis: „Status pro die 13 Decembris 1937 a".

Oprawa: jak w poz. 2.

Sygn.: KUL V-6861A/1938.

E. - , L. - Z. -

6. [cz. 1] Ordo [...] pro Anno Domini 1939, [b.m. 1938], sumptibus Claromontanis, Typis Officinae „Powściągliwość i Praca" - Cracoviae, 17 cm., 182 ss. + wklejka.

Treść: Regulae in missae celebratione servandae, jak w poz. 2.

[cz. 2] Elenchus patrum ac fratrum officialium nec non residentium pro monasteriis destinatorum auctoritate Admodum Reverendi p. Pii Przezdziecki prioris generalis concinnatus pro anno Dni 1939, s. 165-182.

Treść: skład osobowy domów zakonnych w tym w Rzymie i na Węgrzech, necrologus.

Uwagi: zmiana tytułu schematyzmu w stosunku do poz. 3; rogi kart oraz same karty odcinane, umożliwiające łatwiejsze wyrywanie ich, napis: ,Status pro die 31 Decembris 1938".

Oprawa: jak w poz. 2.

Sygn.: KUL V-6861A/1939.

E. - , L.,- Z. -

7. Sygn.: KUL V-6861A/1953 - brak.

8. Sygn.: KUL V-6861A/1955 - brak.

\section{PIJARZY}

Zakon Kleryków Regularnych Ubogich Matki Bożej Szkół Pobożnych (Ordo Clericorum Regularium Pauperum Matris Dei Scholarum Piarum - SchP, SP).

Zgromadzenie Pijarów założył św. Józef Kalasacjusz w roku 1617 w Rzymie w celu ewangelizowania i wychowywania młodzieży. W 1620 r. zostało ono przekształcone w zakon.

Zakon sprawdził przybył w 1642 r., by już 20 lat później utworzyć samodzielną prowincję polską (XV.1) (w 1736 r. ukonstytuowała się prowincja litewska). Pierwsze kolegia pijarskie powstały w Warszawie, Rzeszowie i Podolińcu. Odnowienie zakonu po dziewiętnastowiecznych kasatach na ziemiach polskich, nastąpiło w Krakowie w 1879 r. Pijarzy po 1918 r. (XV.2. Zakon w II Rzeczypospolitej) prowadzą nieprzerwanie swoją działalność do dnia dzisiejszego w ramach ponownie uformowanej od 1957 r. prowincji polskiej.

\section{XV.1. PROWINCJA POLSKA (do 1864 r.)}

1. [cz. 2] Catalogus Clericorum Regularium Pauperum Matris Dei Scholarum Piarum Provinciae Polonae ex Anno Domini 1824 in 1825 sub auspiciis Reverendissimi P. Cajetani Kamieński praepositi provincialis regiminis ejus anno VII mo, Varsaviae 1825, $17 \mathrm{~cm}$., [3] ss.

Treść: władze Zakonu, skład osobowy poszczególnych domów zakonnych, Piaristae qui diu vixerunt, In libro impresjo contenti., Elenchus defunctorum $[\ldots]$.

Oprawa: papier, miękka, napis atramentem: „1888. I. 107”.

Sygn.: KUL-V 16751/1824/25.

E. -, L. -, Z. -

2. [cz. 1] Additamenta directorio officii divini et missarum pro Anno Domini 1830 Congregationi CC. RR. Matris Dei Scholarum Piarum juxta privilegia summo- 
rum pontificium constitutionesque ac ordinationes ejusdem accommodata, Varsaviae 1830, [b.w.], Typis Scholarum Piarum, 17 cm., [18] ss.

Treść: zasadniczy zrąb kalendarza.

Oprawa: papier, miękka.

Sygn.: KUL-V 17799/1830.

E. - , L.,- Z. -

\section{XV.2. ZAKON W II RZECZYPOSPOLITEJ}

1. [cz. 2] Catalogus Provinciae Poloniae Scholarum Piarum anni 1935, Cracoviae 1935, [b.w.], Drukarnia „Róż św. Teresy", $20 \mathrm{~cm} ., 24$, [2] ss., [1] k.

Treść: władze Zakonu, skład osobowy poszczególnych domów zakonnych, Catalogus Ordine vestitionis, zestawienie liczby zakonników, Provinciarum Collegiorumque Ordinis [...] anni 1934, Index rerum.

Oprawa: papier, miękka, napis jak na str. tyt., herb Zakonu.

Sygn.: KUL-V 16751/1935.

E. - , L. - , Z. -

\section{REFORMACI}

Reformaci (Ordo Fratrum Minorum S. Francisco Strictoris Observantiae Reformatorum - OFM Ref.).

Inicjatorem ruchu odnowy Zakonu Braci Mniejszych Obserwantów był w latach 20. XVI w. o. Stefan Molina działający we Włoszech.

W Polsce, reformaci utworzyli pierwszy klasztor w 1622 r., a już rok później powstały dwie kustodie. W 1639 r. zostały one podniesione do rangi prowincji: małopolskiej pw. M.B. Anielskiej i wielkopolskiej pw. św. Antoniego. Z pierwszej z nich wyodrębniła się prowincja ruska pw. M.B. Bolesnej (1763 r.), z drugiej natomiast prowincja pruska pw. Wniebowzięcia NMP (1750 r.).

Po I rozbiorze z części klasztorów pro- wincji małopolskiej i ruskiej utworzono w 1785 r. prowincję galicyjską pw. M.B. Bolesnej. Jej zasięg powiększono w 1806 r. przyłączając klasztory $\mathrm{z}$ terenu Galicji Zachodniej. Tak powstała prowincja „Obojga Galicji”, która przejęła wezwanie dawnej prowincji małopolskiej i przetrwała do 1810 r. Wówczas to nastąpiło kolejne rozdzielenie: prowincja małopolska M.B. Anielskiej (XVI.1) objęła domy na terenie Księstwa Warszawskiego, a następnie Królestwa Polskiego, prowincja galicyjska pw. M.B. Bolesnej (XVI.2) - klasztory w Galicji. W tej ostatniej, po okresie kasat i wzmożonego nadzoru ze strony władz państwowych, możliwe było w miarę spokojne funkcjonowanie tejże jednostki przez cały XIX w. W latach 1899-1911 nastąpiło połączenie reformatów z bernardynami (zniesienie odrębności w Zakonie Braci Mniejszych Obserwantów przez papieża Leona XIII) i utworzenie wspólnej prowincji pw. Niepokalanego Poczęcia NMP. Jednak w wyniku starań reformatów w roku 1911 ponownie wyodrębniono ich prowincję (w granicach sprzed 1899 r.). Dała ona początek odnowionej w niepodległej już Rzeczypospolitej prowincji polskiej (XVI. 3). Obecnie reformaci funkcjonują na terenie Polski w ramach dwóch $\mathrm{z}$ pięciu prowincji Braci Mniejszych.

Pierwszy znany w zasobie BU KUL wykaz zmarłych zakonu reformatów w $D i$ rectorium (na rok 1811), powstały na podstawie danych osobowych z 1810 r. odzwierciedla zapewne stan prowincji galicyjskiej sprzed jej podziału. Kolejne roczniki obejmują już prowincję M.B. Anielskiej na terenie Królestwa Polskiego.

\section{XVI.1. PROWINCJA MALOPOLSKA (po 1810 r.)}

1. [cz. 1] Directorium divini officii ac missarum celebrandarum ad usum FF. Minorum Reformatorum Provinciae SS. V. Mariae Angelorum pro Anno Domini 1811 ordinatum, Cracoviae [1810], [b.w.], Typis 
Annae Dziedzicka, 15 cm., [75] ss.

Treść: zasadniczy zrąb kalendarza.

[cz. 1a] Pia memoria 1809-1810, s. [75].

\footnotetext{
Oprawa: brak.

Sygn.: KUL V-6847/1811.

E. - , L. - , Z. -
}

2. [cz. 1] Directorium [...] celebrandarum juxta rubricas Breviarii ac Missalis Romano-Seraphici ad usum [...] pro Anno Domini 1822 ordinatum, [b.m. 1821], [b. w.d.], $17 \mathrm{~cm}$., [57] ss.

Treść: jak w poz. 1.

[cz. 2] Pia memoria, s. [57].

Uwagi: zmiana tytułu kalendarza w stosunku do poz. 1; napis ,,ad chorem pro pter Verzento, na k 28 napis ołówkiem” „dar Sem. Duchownego w Sandomierzu 1851 r.”, 2 karty kalendarz uszkodzone.

Oprawa: brak.

Sygn.: KUL V-6847/1822.

E. -, L. - Z. -

3. [cz. 1] Directorium divini officii ac missarum celebrandarum ad usum Fratrum Minorum Reformatorum Provinciae SS. V. Mariae Angelorum in Polonia pro anno bissextili 1848 ordinatum, Varsaviae [1848], [b.w.], Typis Scholarum Piarum, $17 \mathrm{~cm} ., 52 \mathrm{ss}$.

Treść: jak w poz. 1.

[cz. 1a] Pia memoria, s. 48.

[cz. 2] Tabula generalia patrum ac fratrum Reformatorum Prviae SSmae V. Mariae Angelorum in Polonia, s. 49-52.

Treść: skład osobowy poszczególnych domów zakonnych.

Proweniencja: „Dar Sem. Duch. w Sandomierzu 1951 r."

Uwagi: zmiana tytułu kalendarza w stosunku do poz. 2.

Oprawa: brak.

Sygn.: KUL V-6847/1848.

E. -, L. -, Z. -

4. [cz. 1] Directorium [...] pro anno Dni bissextili 1864 ordinatum, Varsaviae
[1863], [b.w.], Typis August. Liefeldt, 17 cm., 55 ss.

Treść: jak w poz. 1.

[cz. 2] Tabula totius Provinciae SS. V. Mariae Angelorum PP. ac FF. Reformatorum in Polonia, s. 45-55.

Treść: władze Zakonu, skład osobowy poszczególnych domów zakonnych, modlitwy, Imperialis ac regalis palatia dies festivi, Phases lunae, Tabula ortus et occasus solis.

Proweniencja: „Dar Sem. Duch. w Sandomierzu 1951 r."

Uwagi: tytuł kalendarza ze zmianą w stosunku do poz. 3 - zamiast: Fratrum Minorum Reformatorum, jest: FF Minorum Reformatorum.

Oprawa: brak.

Sygn.: KUL V-6847/1864.

E. cz. 1, t. 1, s. 317 , L. - Z. -

\section{XVI.2. PROWINCJA GALICYJSKA (1810-1918)}

1. [cz. 2] Schematismus patrum ac fratrum Ordinis Minorum S.P. Francisci Strictioris Observantiae Reformatorum Provinciae Galicianae sub titulo Bsmae Virginis Mariae Dolorosae in annum MDCCCLXII [1862], [b.m. 1861], [b.w.d.], 19 cm., 16 ss.

Treść: władze Zakonu, obszerna historia zakonu ze szczególnym uwzględnieniem historii lat 15191816, krótka historia oraz skład osobowy poszczególnych domów zakonnych, zestawienie liczby zakonników, Pia memoria.

Oprawa: papier, miękka.

Sygn.: KUL V-1398/1862.

E. - , L. - , Z. -

2. [cz. 1] Directorium divini officii ac missarum celebrandarum Romano-Seraphici Breviarii et Missalis rubricis accomodatum ad usum Fratrum Minorum Strictoris Observantiae Reformatorum Provinciae B.V. Mariae Dolorosae in Galicia pro Anno Domini MDCCCLXX [1870] sub regimine officii provincialatus A.R.P. Laurentii Ciepliński ministri provincialis, Cracoviae 1870, [b.w.], Ex Typographia 
Kirchmayeriana, 19 cm., 40 ss.

Treść: zasadniczy zrąb kalendarza.

[cz. 1a] Pia memoria, s. 40.

Oprawa: papier, miękka.

Sygn.: KUL V-6836/1870.

E. cz. 1 , t. 1 , s. 317 , L. - Z. -

3. [cz. 2] Schematismus patrum ac fratrum Ordinis Minorum S.P.N. Francisci Strictioris Observantiae Reformatorum Provinciae B.V.M. Dolorosae Galicianae pro Anno Domini MDCCCLXX [1870], Cracoviae 1870, [b.w.], Ex Typographia Kirchmayeriana, $19 \mathrm{~cm} ., 20$ ss.

Treść: władze Zakonu, obszerna historia zakonu ze szczególnym uwzględnieniem historii lat 15191816, krótka historia oraz skład osobowy poszczególnych domów zakonnych, zestawienie liczby zakonników.

Uwagi: zmiana tytułu schematyzmu w stosunku do poz. 1.

Oprawa: brak.

Sygn.: KUL V-1398/1870.

E. cz. 1 , t. 4 , s. 190 , L. - Z. -

4. [cz. 2] Schematismus [...] pro Anno Domini MDCCCLXXII [1872], Premisliae 1872, [b.w.], Ex Typographia Gr. Cath. Capituli, 19 cm., 20 ss.

Treść: jak w poz. 3.

Oprawa: papier, miękka.

Sygn.: KUL V-6847/1872.

E. - , L. - , Z. -

5. [cz. 2] Schematismus [...] pro Anno Domini MDCCCLXXIII [1873], Premisliae 1873, [b.w.], Ex Typographia Gr. Cath. Capituli, $18 \mathrm{~cm} ., 20$ ss.

Treść: jak w poz. 1.

Oprawa: papier, miękka, napis jak na str. tyt. Sygn.: KUL V-1398/1873.

E. - , L. - , Z. -

6. [cz. 2] Catalogus patrum ac fratrum Ordinis Minorum S.P. Francisci Reformatorum Provinciae B.V.Mariae Dolorosae in pro anno 1875, Cracoviae 1875, [b.w.], Typis Univeristatis Jagellonicae, provisore
Ignatio Stencel, $20 \mathrm{~cm} ., 11 \mathrm{ss}$.

Treść: jak w poz. 1.

Uwagi: zmiana tytułu schematyzmu w stosunku do poz. 3 .

Oprawa: brak.

Sygn.: KUL V1398-/1875.

E. -, L. - , Z. -

7. [cz. 1] Directorium divini officii ac missarum celebrandarum juxta calendarium Romano Seraphici Breviarii et Missalis auctoritate Admodum Reverendi patris Constantii Pacholik quinto ministri provincialis ordinatum ad usum Fratrum Minorum Provinciae B.V. Mariae Dolorosae Reformatorum in Galicia pro anno bissextili 1880, Cracoviae 1880, [b.w.], E Typographia Ephemeridum „Czas”, provisore Josepho Łakociński, 19 cm., 54 ss.

Treść: jak w poz. 2.

[cz. 2] Catalogus partum ac fratrum Ordinis Minorum S.P. Francisci Strictioris Observantiae vulgo Reformatorum Provinciae B.V. Mariae Dolorosae in Galicia pro anno $\mathbf{1 8 8 0}$, s. $43-54$.

Treść: władze Zakonu, skład osobowy poszczególnych domów zakonnych, zestawienie liczby zakonników, Defuncti.

Uwagi: zmiana tytułu kalendarza w stosunku do poz. 2 i schematyzmu w stosunku do poz. 6 .

Oprawa: papier, miękka.

Sygn.: KUL V-6836/1880.

KUL V-1398/1880 - schematyzm.

E. - , L.,- Z. -

8. [cz. 2] Schematismus almae Provinciae B.V. Mariae Dolorosae in Galicia Ordinis Minorum S.P. Francisci Strictioris Observantiae vulgo Reformatorum pro Anno Domini 1883, [b.m. 1882], [b.w.d.], 20 cm., $21 \mathrm{ss}$.

Treść: władze Zakonu, obszerna historia zakonu ze szczególnym uwzględnieniem historii lat 15191816, krótka historia oraz skład osobowy poszczególnych domów zakonnych, zestawienie liczby zakonników, Pia memoria, Series Custodum (1746-1761), Series Ministrorum Provincialium (1763-1809) post particionem Regni (1810-1882). 
Proweniencja: napis atramentem: „Przw. JMC X. Komisarzowi XX. Augustyanów".

Uwagi: zmiana tytułu schematyzmu w stosunku do poz. 7.

Oprawa: papier, miękka, napis jak na str. tyt.

Sygn.: KUL V-1398/1883.

E. - , L. - , Z. -

9. [cz. 1] Directorium divini officii ac missarum celebrandarum juxta peculiares rubricas Breviarii ac Missalis Romano-Seraphici auctoritate Admodum Reverendi patris Joachimi Maciejczyk ministri provincialis ordinatum ad usum Fratrum Minorum Provinciae B.V. Mariae Dolorosae Reformatorum in Galicia pro Anno Domini 1887, Cracoviae 1887, sumptibus PP. Reformatorum, Typis V1. Lud. Anczyc et Sociorum, provisore Joanne Gadowski, 21 cm., 78 ss.

Treść: zasadniczy zrąb kalendarza, Decretum.

[cz. 2] Schematismus [...] pro Anno Domini 1887, s. 53-78.

Treść: jak w poz. 8.

Uwagi: zmiana tytułu kalendarza w stosunku do poz. 7.

Oprawa: papier, miękka, brak okładki z przodu.

Sygn.: KUL V-6836/1887.

KUL V-1398/1887 - schematyzm.

E. cz. 4, t. 4, s. 123 - tylko schematyzm, L. -, Z.

10. [cz. 2] Schematismus [...] pro Anno Domini 1888, [b.m. 1887], [b.w.d.], 19 cm., 26 ss.

Treść: jak w poz. 8 .

Uwagi: ostatnia strona błędnie numerowana.

Oprawa: jak w poz. 7.

Sygn.: KUL V-1398/1888.

E. -, L. -

11. [cz. 2] Schematismus [...] pro Anno Domini 1889, Cracoviae 1888, sumptibus PP. Reformatorum, Typis V. L. Anczyc \& Sociorum, provisore Joanne Gadowski, $18 \mathrm{~cm} ., 28$, [3] ss.
Treść: władze Zakonu, obszerna historia zakonu ze szczególnym uwzględnieniem historii lat 15191816, krótka historia oraz skład osobowy poszczególnych domów zakonnych, zestawienie liczby zakonników, Pia memoria, Series custodum (1746-1761), Series ministrorum provincialium (1763-1809) post particionem Regni (1810-1887), podany także skład osobowy domu zakonnego żeńskiego.

Oprawa: jak w poz. 7.

Sygn.: KUL V-1398/1889.

E. -, L. -, Z. -

12. [cz. 2] Schematismus [...] pro Anno Domini 1892, Cracoviae 1891, sumptibus PP. Reformatorum, E Typografia Związkowa sub directione A. Szyjewski, $19 \mathrm{~cm} ., 30 \mathrm{ss}$.

Treść: jak w poz. 11.

Proweniencja: pieczęć owalna $\mathrm{z}$ napisem: „Biblioteka Uniwer. Lubelskiego".

Uwagi: w katalogu kartkowym BU KUL podany jest rocznik 1891.

Oprawa: brak.

Sygn.: KUL V-1398/1892.

E. - , L. - , Z. -

13. [cz. 2] Schematismus [...] pro Anno Domini 1894, Cracoviae 1893, sumptibus PP. Reformatorum, E Typografia Związkowa sub directione A. Szyjewski, $19 \mathrm{~cm} ., 34$ ss.

Treść: jak w poz. 11.

Oprawa: papier wydaw., napis jak na str. tyt.

Sygn.: KUL V-1398/1894.

E. - , L. - , Z. -

14. Sygn. KUL V-1398/1909 - brak.

\section{XVI.3. PROWINCJA POLSKA (1918-)}

1. [cz. 1] Ordo divini officii recitandi sacrique peragendi pro Anno Domini MCMXXVII [1927] ad usum Fratrum Ordinis Miniorum, ad Claras Aquas 1926, Ex Typographia Collegii S. Bonaventurae, 17 cm., 80 ss., dodatek. 
Treść: Praenotanda, Praxis kalendarii, zasadniczy zrąb kalendarza.

Uwagi: dodatek Variationes in kalendario 1927 a pro nostra Provincia, w katalogu jako rocznik 1926.

Oprawa: papier wydaw., napis jak na str. tyt.

Sygn.: KUL V-6847/1927.

E. - , L. - , Z. -

2. [cz. 2] Schematismus Ordinis Fratrum Minorum S.P.N. Francisci almae Provinciae Beatissimae Virg. Mariae Angelorum in Polonia (olim PP. Reformatorum) pro Anno Domini 1928 auctoritate A.R.P. ministri provincialis ad normam Const. Gnlium n. 394 rite concinnatus a p. Hilario Jarosiewicz, Wielczka 1927, sumptibus FF. Minorum eiusdem Provinciae, Typis Joanni Litwiński, 19 cm., 34 ss.

Treść: historia Zakonu, Series chronologia conventuum [...] in Polonia, Alphabietica series FF Minorum [...] qui vitae sanctitate [...], Series moderatorum, władze Zakonu, skład osobowy poszczególnych domów zakonnych (w tym żeńskiego), Defuncti, Conspectus generalis, Index alphabeticus.

Proweniencja: napis ołówkiem: „Krzysztof Olszewski K1. O.O. Reformatów w Krakowie r. 1928”.

Oprawa: papier wydaw., napis jak na str. tyt.

Sygn.: KUL V-1398/1928.

E. - , L. - , Z. -

3. [cz. 1] Ordo [...] pro Anno Domini MCMXXIX [1929] [...], ad Claras Aquas 1928, Ex Typographia Collegii S. Bonaventurae, $17 \mathrm{~cm} ., 87$, [7] ss.

Treść: Praenotanda, Praxis kalendarii, zasadniczy zrąb kalendarza, Variationes in kalendario [...] [in Polonia].

Oprawa: jak w poz. 1.

Sygn.: KUL V-6847/1929.

E. - , L. - , Z. -

4. [cz. 1] Ordo [...] pro Anno Domini MCMXXX [1930] [...], ad Claras Aquas 1929, Ex Typographia Collegii S. Bonaventurae, $17 \mathrm{~cm} ., 87$, [8] ss.

Treść: jak w poz. 3 .

Uwagi: w katalogu BU KUL jako rocznik 1929
Oprawa: jak w poz. 1.

Sygn.: KUL V-6847/1930.

E. -, L. - , Z. -

5. [cz. 1] Ordo [...] anno bissextile Domini MCMXXXII [1932] [...], ad Claras Aquas 1931, Ex Typographia Collegii S. Bonaventurae, 17 cm., 87, [8] ss.

Treść: jak w poz. 3 .

Uwagi: druk na okładce z tyłu: „Formula Absolutionis Generalis" w katalogu jako rocznik 1931.

Oprawa: papier wydaw., napis podobny jak na str. tyt., dodano na jego końcu: „Prov. B.V.M. Angelorum".

Sygn.: KUL V-6847/1932.

E. - , L. - , Z. -

6. [cz. 1] Ordo divini officii recitandi sacrique juxta kalendarium romano-seraphicum Anno Domini MCMXXXIV [1934] de mandato r..mi [!] p. Leonardi Mariae Bello ministri generalis totius Ordinis Fratrum Minorum confectus et dispositus pro fratribus Ordinis Minorum et pro sororibus II et III Ordinis ejus curae subjectis, Assisii 1933, Typ. Portiunculae, 17 cm., 103, [8] ss.

Treść: jak w poz. 3 .

Uwagi: zmiana tytułu kalendarza w stosunku do poz. 1, w katalogu jako rocznik 1933.

Oprawa: jak w poz. 8.

Sygn.: KUL V-6847/1934.

E. - , L. - , Z. -

7. [cz. 2] Schematismus Ordinis Fratrum Minorum S.P.N. Francisci almae Provinciae Beatissimae Virg. Mariae Angelorum in Polonia (olim PP. Reformatorum) pro Anno Domini 1934 auctoritate A.R.P. ministri provincialis ad normam Const. Generalium n. 394 rite concinnatus, [b.m. 1933], [b.w.], Typis FF Minorum Panevnici, 19 cm., 86 ss., [1] k.

Treść: władze zwierzchnie, Origo et historia brevis [...] in Polonia, Series chronologica conventuum PP. Reformatorum in Polonia, Alphabetica series FF. Minorum [...], historia poszczególnych konwentow i skład osobowy (w tym żeńskiego), Tempore 1927-1933 inclus, indeks. 
Uwagi: zmiana tytułu schematyzmu. w stosunku do poz. 2.

Oprawa: papier, półmiękka, oryginalna.

Sygn.: KUL V-4002a/1934.

E. - , L. - , Z. -

8. [cz. 2] Schematyzm Prowincji Matki Bożej Anielskiej OO. Franciszkanów Reformatów w Polsce 1971, red. Grzegorz Wiśniowski, Kraków 1971, OO. Franciszkanie - Reformaci, Drukarnia Loretańska, $21 \mathrm{~cm} ., 172$ ss., mapa + fotografie.

Treść: historia Zakonu, władze zwierzchnie, skład osobowy poszczególnych domów zakonnych, adresy, zestawienie liczby zakonników, szczegółowe informacje.

Uwagi: zmiana tytułu schematyzmu. w stosunku do poz. 2; całość w jęz. pol.

Oprawa: papier, półmiękka - oryginalna, tektura, twarda - wtórna.

Sygn.: KUL V-4002/1971.

Sygn.: KUL V-1398/1971.

E. -, L. -, Z. -, W. poz. 318 .

\section{SALEZJANIE}

Towarzystwo Świętego Franciszka Salezego (Societas Sancti Francisci Salesii - SDB).

Salezjanie powstali z inicjatywy św. Jana Bosko w 1859 r. w Turynie. Pierwsi salezjanie przybyli do Polski w 1898 r. W 1919 r. powstała prowincja (inspektoria) polska, która uległa podziałowi w $1933 \mathrm{r}$. na inspektorię południową (krakowską) pw. św. Jacka (XVII.1) oraz na inspektorię północną (warszawską) pw. św. Stanisława Kostki (XVII.2). Stan ten trwał do roku 1980, kiedy to utworzono dwie kolejne prowincje: pilską i wrocławską.

\section{XVII.1. INPEKTORIA POLUDNIOWA (KRAKOWSKA) (1933-1980)}

1. [cz. 2] Elenko. Wykaz miejscowości i współbraci Inspektorii św. Jacka
1972/73 r., Kraków [1972], [b.w.], D. Z., 29, 102 ss.

Treść: władze Zgromadzenia, skład osobowy poszczególnych domów, adresy.

Proweniencja: pieczęć prostokątna o treści: „Towarzystwo Naukowe KUL Redakcja Encyklopedii Katolickiej Lublin, Fr. Chopina 27 - V piętro".

Uwagi: maszynopis; tytuł ze strony tytułowej oraz okładki; na okładce herb Zgromadzenia; jęz. pol.

Oprawa: papier wydaw.

Sygn.: KUL V-23274/1972/73.

E. -, L. - , Z. -

2. [cz. 2] Wykaz placówek i współbraci Polskich Inspektorii Towarzystwa Salezjańskiego 1973/74 r., Kraków-Łódź [1973], Insp. Tow. Sal.,[b.d.], 29, 93 ss.

Treść: jak w poz. 1.

Uwagi: zmiana tytułu schematyzmu. w stosunku do poz. 1; maszynopis, na okładce napis długopisem: „Lublin ul. Nowotki”, jęz. pol.

Oprawa: jak w poz. 1.

Sygn.: KUL V-23274/1973/74.

E. -, L. -, Z. -, W. poz. 325 ,

3. [cz. 2] Towarzystwo św. Franciszka Salezego w Polsce. Wykaz domów i współbraci [na rok 1975]. Stan z dnia 1 września 1974 r., red. Ludwik Kaliński, KrakówŁódź [1974], Salezjańskie Inspektorie Kraków-Łódź, Zakłady Graf. „Tamka”, 20 cm., 279 ss. + fotografie, mapa.

Treść: jak w poz. 1.

Uwagi: zmiana tytułu schematyzmu w stosunku do poz. 2; jęz. pol.

Oprawa: jak w poz. 1.

Sygn.: KUL V-23274/1975.

E. -, L. - Z. -

4. [cz. 2] Towarzystwo św. Franciszka Salezego. Wykaz placówek i współbraci Polskich Prowincji Towarzystwa Salezjańskiego 1978/79 r., Kraków-Łódź [1978], [b.w.d.], $20 \mathrm{~cm} ., 159$ ss.

Treść: jak w poz. 1.

Uwagi: schematyzmu zmiana tytułu schematyzmu. w stosunku do poz. 3; maszynopis, jęz. pol. 
Oprawa: jak w poz. 1.

Sygn.: KUL V-23274/1978/79.

E. -, L. -, Z. -, W. poz. 325 .

5. [cz. 2] Rodzina Salezjańska w Polsce. Wykaz domów i osób [na rok 1988] w 100-lecie śmierci św. Jana Bosko. (Stan z dnia 1 stycznia 1987 r.), oprac. Ludwik Kaliński, Warszawa 1988, Wydawnictwo Salezjańskie, Drukarnia Diecezjalna w Katowicach, $20 \mathrm{~cm}$., $635 \mathrm{ss}$. + fotografie, mapy.

Treść: jak w poz. 1

Uwagi: zmiana tytułu schematyzmu. w stosunku do poz. 4; jęz. pol.

Oprawa: jak w poz. 1.

Sygn.: KUL V-23274/1988.

E. - , L. - , Z. - , W. poz. 325 .

6. [cz. 2] Wykaz placówek i współbraci Polskich Prowincji Towarzystwa Salezjańskiego 1997/98 r., red. Stanisław Kuciński, Kraków 1997, Inspektorat Towarzystwa Salezjańskiego, 20 cm., 308 ss.

Treść: jak w poz. 1 .

Uwagi: zmiana tytułu schematyzmu w stosunku do poz. 4; maszynopis, jęz. pol.

Oprawa: jak w poz. 1.

Sygn.: KUL V-23274/1997/98.

E. -, L. - , Z. -

\section{XVII.2. INSPEKTORIA PÓLNOCNA (WARSZAWSKA) (1933-1980)}

1. [cz. 2] Elenko 1994/95. Towarzystwo św. Franciszka Salezego. Inspektoria świętego Stanisława Kostki, Warszawa [1994], [b.w.], Drukarnia Archidiecezjalna w Katowicach, 15 cm., 84 ss.

Treść: władze zwierzchnie, skład osobowy poszczególnych domów, adresy.

Uwagi: jęz. pol.

Oprawa: papier wydaw., herb Zakonu.

Sygn.: KUL V-33540/1994/95.

E. - , L. - , Z. -

2. [cz. 2] Elenko 1995/96. Towarzystwo św. Franciszka Salezego. Inspektoria świętego Stanisława Kostki, Warszawa [1995], [b.w.], Drukarnia Archidiecezjalna w Katowicach, 15 cm., 94 ss., [1] k.

Treść: jak w poz. 1 .

Uwagi: zmiana tytułu schematyzmu w stosunku do poz. 1; jęz. pol.

Oprawa: papier wydaw., herb Zakonu.

Sygn.: KUL V-33540/1995/96.

E. - , L. - , Z. -

\section{SALEZJANIE POZA KRAJEM}

Roczniki te obejmują nazwiska salezjanów i salezjanek należących do polskich prowincji, pochodzących $\mathrm{z}$ polskich prowincji, utrzymujących związki z Polską.

1. [cz. 2] Elenko. Polska Rodzina Salezjańska poza krajem 1996-1997, Warszawa [1996], Salezjański Ośrodek Misyjny, [b.d.], $20 \mathrm{~cm} ., 98 \mathrm{ss}$.

Treść: władze zwierzchnie, skład osobowy poszczególnych domów, adresy.

Uwagi: jęz. pol.

Oprawa: papier wydaw.

Sygn.: KUL V-33499/1996/97.

E. - , L. - , Z. -

2. [cz. 2] Elenko. Polska Rodzina Salezjańska poza krajem 1998-1999, Warszawa [1998], Salezjański Ośrodek Misyjny [b.d.], $21 \mathrm{~cm} ., 98 \mathrm{ss}$

Treść: jak w poz. 1 .

Uwagi: zmiana tytułu schematyzmu. w stosunku do poz. 1; jęz. pol.

Oprawa: papier wydaw., półmiękka.

Sygn.: KUL V-33499/1998/99.

E. - , L. - , Z. -

\section{SALWATORIANIE}

Towarzystwo Boskiego Zbawiciela (Societas Divini Salvatoris - SDS).

Towarzystwo założył w 1881 r. w Rzymie ks. Franciszek Maria od Krzyża Jordan (1848-1918).

Salwatorianie pojawiają się w Polsce 
w 1900 r, natomiast pierwsza placówka powstaje w roku 1903 r. w Trzebini. Dalszy rozwój Zgromadzenia doprowadził do powstania komisariatu w 1922 r., a następnie erygowania prowincji polskiej w 1927 r.

1. Katalog Salwatorianów Prowincji Polskiej [1975], red. Antoni Kiełbasa SDS i in., Kraków 1975, Wydawnictwo Salwatorianów, Tipografia P.U.G. - Roma, 17 cm., 313 ss.

Oprawa: papier, twarda, napis jak na str. tyt.

Uwagi: jęz. polski.

Sygn.: KUL-V 20580/1975.

E. -, L. -, Z. -, W. poz. 308.

\section{SERCANIE}

Zgromadzenie Księży Najświętszego Serca Jezusowego (Congregatio Sacerdotum a Sacro Corde Jesu - SCJ).

Zgromadzenie to założył w 1878 r. ks. Leon Jan Dehon, a zatwierdził w 1888 r. Leon XIII. Do Polski sercanie zostali sprowadzeni przez ks. Kazimierza Wiechcia w roku 1928. Prowincję polską erygowano w $1947 \mathrm{r}$.

1. [cz. 1] Kalendarium Collegia Maximi Cracoviensis SS. Cordis Jesu 19301931, Cracoviae 1930, [b.w.d.], 16 cm., [32] ss.

Treść: zasadniczy zrąb kalendarza, Catalogus Professorum, Auditores Philosopiae.

Uwagi: maszynopis, tytuł z oprawy, jęz. polski. Oprawa: papier wydaw., napis jak na str. tyt.

Sygn.: KUL-V-10535/1930/31.

E. - , L. - , Z. -

2. [cz. 2] Elenchus Polskiej Prowincji Zgromadzenia Księży Najświętszego Serca Jezusowego [1997], Warszawa 1997, Kuria Prowincjalna Księży Sercanów, [b. d.], 20 cm., 183 ss., [2] kk.

Treść: władze Zgromadzenia, skład osobowy poszczególnych domów zakonnych, adresy, indeksy.

Uwagi: zmiana tytułu schematyzmu. w stosunku do poz. 1; na str. tyt. herby Zgromadzenia, całość w jęz. pol.
Oprawa: jak w poz. 1.

Sygn.: KUL-V-36583/1997.

E. -, L. -, Z. -

\section{ZAKONY ŻEŃSKIE}

\section{AUGUSTIANKI}

Augustianki - jako Drugi Zakon św. Augustyna znany jest od XIII w.

W Polsce augustiankom został ufundowany klasztor św. Katarzyny w Krakowie w 1583 r., który funkcjonuje do dzisiaj. Siostry mimo klauzurowego charakteru zakonu, zaangażowały się w działalność edukacyjno-wychowczą prowadząc szkoły dla dziewcząt.

1. [cz. 2] Szematyzm Sióstr Św. Ojca Augustyna klasztoru krakowskiego św. Katarzyny P. i M. fundowanego w roku 1565 przez ks. Szymona z Łowicza Mniszka S.T.D. Prowincjała kks. Augustyjanów sporządzony według obiorów dokonanych na kapitule klasztornej odbytej dnia 6 kwietnia 1869 r. pod przewodnictwem WKs. Zygmunta Wołka, S.T.D., eksporwincyjała, komisarza jeneralskiego zakonu augustyjańskiego, Kraków 1870, nakładem kks. Augustyjanów, w drukarni Karola Budweisera, $18 \mathrm{~cm}$., 16 ss.

Treść: słowo wstępu do przełożonej autustianek S. Antoniny Cofałki, skład osobowy klasztoru, wykaz zmarłych sióstr od 1815 r., poczet przełożonych od $1709 \mathrm{r}$.

Proweniencja: pieczęć owalna z napisem: „Z Biblioteki X. Zygmunta Wołek".

Uwagi: całość w jęz. pol., współoprawny schematyzm z $1885 \mathrm{r}$.

Oprawa: twarda, tektura

Sygn.: KUL-V-10451/1870.

E. - , L. - , Z. -

2. [cz. 2] Szematyzm [...] sporządzony według obiorów dokonanych na kapitule klasztornej odbytej dnia 13 kwietnia 1885 r. [...], Kraków 1885, nakładem XX. Augustyjanów, w drukarni Uniwersytetu 
Jagiellońskiego, $20 \mathrm{~cm} ., 16$ ss.

Treść: słowo wstępu, skład osobowy klasztoru, wykaz zmarłych sióstr od 1800 r., poczet przełożonych od $1709 \mathrm{r}$.

Uwagi: zmiana tytułu schematyzmu. w stosunku do poz. 1; całość w jęz. pol.

Oprawa: papier wydaw.

Sygn.: KUL-V-10451/1885.

E. - , L. - , Z. -

\section{BOROMEUSZKI MIKOLOWSKIE}

\section{Zgromadzenie Sióstr Miłosierdzia} św. Karola Boromeusza w Mikołowie (Congregatio Sororum Misericordiae Sancti Caroli Borromei - SCB).

Powstało ono w poł. XVII w. (ostatecznie zatwierdzone przez Stolicę Apostolską w 1892 r.) z inicjatywy Józefa Chauvenel'a. Siostry przybyły do Nysy Śląskiej z Czech w 1848 r. a następnie rozszerzyły swą działalność na ziemie polskie.

W 1939 r. boromeuszki mikołowskie usamodzielniły się, tworząc prowincję polską podległą domowi generalnemu w Trzebnicy, a w 1945 r. stając się samodzielnym Zgromadzeniem.

1. [cz. 1] Katalog Zgromadzenia Sióstr Miłosierdzia św. Karola Boromeusza w Mikołowie (stan z dnia 1 lutego 1996 ro$\mathrm{ku}$ ), red. Jarosław Arcyz, [b.m. 1995], [b.w.], Drukarnia Archidiecezjalna w Katowicach, $20 \mathrm{~cm}$., $220 \mathrm{ss}$. + mapy, fotografie.

Treść: skład osobowy poszczególnych domów, obszerne informacje dotyczące Zgromadzenia, rys historyczny, zarząd, adresy, indeksy,

Uwagi: jęz. pol., na str. tyt. i okładce - herb Zgromadzenia.

Oprawa: papier wydaw., napis jak na str. tyt.

Sygn.: KUL-V-33752/1996.

E. - , L. - , Z. -

2. [cz. 2] Schematismus der Congregation der armherzigen Schwestern vom hl. Carolus Borromäus. 1896, Breslau
[1895]. [b.w.], Druck der Schlesischen Volkszeltung (Grosser \& Comp.), 29, 137 ss.

Treść: skład osobowy poszczególnych domów, Katalogisches Verzeichnis [...], Nachtarg und Berichtigungen, Alphabetisches Register [...], wykaz zmarłych, zestawienie liczby zakonników.

Uwagi: zmiana tytułu schematyzmu. w stosunku do poz. 1; jęz. niemiecki, notatki atramentem.

Oprawa: papier, wydaw., napis jak na str. tyt., herb Zakonu.

Sygn.: KUL V-7586/1896.

E. - , L. - , Z. -

\section{PREMNOSTRATENKI (NORBERTANKI)}

Zakon premostratenek założył św. Norbert w latach 20. XI wieku w Premontre we Francji. Norbertanki osiedliły się w Polsce w 1126 r. będąc tym samym najstarszym zakonem żeńskim.

Przed rozbiorami Polski istniało 11 klasztorów sióstr w tym na Zwierzyńcu. Fundatorem klasztoru był Jaksa Gryfita w 1162 roku. Siostry norbertanki mieszkają w tym miejscu do dzisiaj.

1. [cz.1] Directorium officii divini juxta Rubricas Canonici Ordinis Praemonstratensis pro Anno Domini post bissextilem 2 do et embolismalem 1 mo 1830 sumptibus Religiosissimae Abbatissae Eumphemiae Ottffianowska totiusq. Parthenonis Zverinecensis Ordinis ejusdem impressum, usui locali accommdatum per Joan. Nep. Schmiedt, conventus Hebdoviensis suppressi professum, cooperatorem Krzyżanovicensem conscriptum, Cracoviae [1829], [b.w.], Typis Academicis, 16 cm., 37 ss.

Treść: zasadniczy zrąb kalendarza.

Oprawa: papier, miękka.

Sygn.: KUL-V 10446/1830.

E. - , L. - , Z. -

2. [cz. 1] Directorium divini officii secundum ritum Sacri ac Canonici Ordinis Praemonstratensis usui celeberrimi Parthenonis Zverinecensis accomdatum pro Anno 
Domini MDCCCLV [1855],Cracoviae 1855, [b.w.], impressum in Typographia „Czas”, $20 \mathrm{~cm} ., 40 \mathrm{ss}$.

Treść: kalendarium Zakonu, zasadniczy zrąb kalendarza.

[cz. 2] Schematismus virginum canonissarum Ordinis Praemonstratensis in Magno Ducatu Cracoviensi, s. 37-40.

Treść: skład osobowy poszczególnych domów zakonnych (w tym zmarłych).

Uwagi: zmiana tytułu schematyzmu. w stosunku do poz. 1; wklejona kartka z pieczątką i napisem: „Księgarnia. Antykwariat Dom Książki E 270505”.

Oprawa: papier, miękka, ozdobna, napis podobny jak na str. tyt.

Sygn.: KUL-V 10446/1855.

E. cz. 1, t. I, s. 316 , L. - Z. -

3. [cz. 1] Directorium [...] pro Anno Domini MDCCCLVI [1856] bissextili, Cracoviae [1855], [b.w.], Typis Typographiae „Czas”, 19 cm., 44 ss.

Treść: jak w poz. 2.

[cz. 2] Schematismus [...], s. 41-44.

Treść: jak w poz. 2.

Oprawa: jak w poz. 2.

Sygn.: KUL-V 10446/1856.

E. cz. 1, t. I, s. 316 , L. -, Z. -

4. [cz. 1] Directorium divini officii secundum ritum Sacri ac Canonici Ordinis Praemonstratensis usui Parthenonis Canonissarum Ord. Praemonstr. in Zwierzyniec accommdatum pro Anno Domini MDCCCLX [1860] bissextili, Cracoviae 1860, [b.w.], impressum in Typographia Caroli Budweiser, 19 cm., 48 ss.

Treść: jak w poz. 2.

[cz. 2] Catalogus virginum canonissarum Ordinis Praemonstratensis, s. 44-48.

Treść: jak w poz. 2.

Uwagi: zmiana tytułu w stosunku do poz. 2.

Oprawa: jak w poz. 2.

Sygn.: KUL-V 10446/1860.

E. cz. 1, t. I, s. 316 , L. -, Z. -

5. [cz. 1] Directorium divini officii se- cundum ritum Sacri ac Canonici Ordinis Praemonstratensis usui Parthenonis Canonissarum Ord. Praemonstrat. in Zwierzyniec accommdatum pro Anno Domini MDCCCLXIX [1869], post bissextilem primo, Cracoviae 1869, [b.w.], Typis Ladislai Jaworski, 18 cm., 39 ss.

Treść: jak w poz. 2.

[cz. 2] Cathalogus [...], s. 38-39.

Treść: skład osobowy domu zakonnego.

Uwagi: zmiania tytułu kalendarza w stosunku do poz. 4.

Oprawa: papier, miękka, tylna okładka - wizerunek Matki Boskiej Niepokalanie Poczętej, ozdobna, napis podobny jak na str. tyt.

Sygn.: KUL-V 10446/1869.

E. cz. 1 , t. I, s. 316 , L. - Z. -

6. [cz. 1] Directorium [...] pro Anno Domini MDCCCLXXI [1871] post bissextilem tertio, Cracoviae 1871, [b.w.], Typis Ladislai Jaworski, 21 cm., 28, [4] ss.

Treść: jak w poz. 2.

[cz. 2] Cathalogus [...], s. [4].

Treść: jak w poz. 5 .

Oprawa: jak w poz. 5.

Sygn.: KUL-V 10446/1871.

E. - , L. - , Z. -

7. [cz. 1] Directorium [...] pro Anno Domini MDCCCLXXII [1872] pro anno bissextili, Cracoviae 1872, [b.w.], Typis Universitatis Jagiellonicae, provisore C. Mańkowski, 14 cm., 39, [5] ss.

Treść: jak w poz. 2. s. [1].

[cz. 1a] Elenchus [...] defunctorum,

[cz. 2] Cathalogus [...], s. [2-5].

Treść: jak w poz. 5 .

Oprawa: jak w poz. 5.

Sygn.: KUL-V 10446/1872.

E. cz. 1, t. I, s. 17, L.-, Z.-

8. [cz. 1] Directorium [...] pro Anno Domini MDCCCLXXIII [1873], post bissextilem primo, Cracoviae 1873, [b.w.], Typis Universitatis Jagellonicae, provisore C. Mańkowski, 20 cm., 36 ss. 
Treść: jak w poz. 2.

[cz. 2] Cathalogus [...], s. 35-36.

Treść: jak w poz. 5 .

Oprawa: jak w poz. 2.

Sygn.: KUL-V 10446/1873.

E. cz. 1, t. I, s. 17, L. - Z. -

9. [cz. 1] Directorium [...] pro Anno Domini MDCCCLXXVI [1876] bissextili, Cracoviae 1876, [b.w.], Typis Universitatis Jagiellonicae, provisore Ignatio Stelcel, $18 \mathrm{~cm} ., 36 \mathrm{ss}$.

Treść: jak w poz. 2 .

[cz. 2] Catalogus [...], s. 35-36.

Treść: jak w poz. 5 .

Oprawa: jak w poz. 5 .

Sygn.: KUL-V 10446/1876.

E. - , L. - , Z. -

10. [cz. 1] Directorium [...] pro Anno Domini MDCCCLXXIX [1879], post bissextilem tertio, Cracoviae 1879, [b.w.], Typis Universitatis Jaiellonicae, provisore Ignatio Stelcel, $18 \mathrm{~cm}$., [36] ss.

Treść: jak w poz. 2.

[cz. 2] Catalogus virginum canonissarum Ordinis Praemonstratensis in Magno Ducatu Cracoviensi, s. [36].

Treść: jak w poz. 2.

Uwagi: notatki odręczne.

Oprawa: jak w poz. 5.

Sygn.: KUL-V 10446/1879.

E. -, L. -, Z. -

11. [cz. 1] Directorium [...] pro Anno Domini MDCCCLXXX [1880] bissextili, Cracoviae 1880, [b.w.], Typis Universitatis Jagellonicae, provisore Ignatio Stelcel, 17 cm., 38, [2] ss.

Treść: jak w poz. 2.

[cz. 2] Catalogus [...], [2] ss.

Treść: jak w poz. 5, zestawienie liczby zakonników.

Oprawa: jak w poz. 5.

Sygn.: KUL-V 10446/1880.

E. - , L. - , Z. -
12. [cz. 1] Directorium [...] pro Anno Domini MDCCCLXXXI [1881] post bissextilem primo, Cracoviae 1880, sumptibus Parthenonis Zverinecensis, Typis Universitatis Jagellonicae, provisore Ignatio Stelcel, $18 \mathrm{~cm} ., 38$, [2] ss.

Treść: jak w poz. 2.

[cz. 2] Catalogus [...], [2] ss.

Treść: skład osobowy poszczególnych domów zakonnych (w tym zmarłych), zestawienie liczby zakonników.

Oprawa: jak w poz. 5.

Sygn.: KUL-V 10446/1880.

E. - , L. - , Z. -

13. [cz. 1] Directorium [...] pro Anno Domini MDCCCLXXXII [1882] post bissextilem secundo, Cracoviae 1882, sumptibus Parthenonis Zverinecensis, Typis Universitatis Jagiellonicae, provisore Ignatio Stelcel, 19 cm., 36, [3] ss.

Treść: jak w poz. 2, Scitu utilia.

[cz. 2] Catalogus [...], [3] ss.

Treść: skład osobowy domu zakonnego, zestawienie liczby zakonników, Necrologium ojca Eugeniusza Karola Tapy.

Uwagi: notatki ołówkiem.

Oprawa: jak w poz. 5.

Sygn.: KUL-V 10446/1882.

E. - , L. - , Z. -

14. [cz. 1] Directorium [...] pro Anno Domini MDCCCLXXXIII [1883], post bissextilem tertio, Cracoviae 1883, sumptibus Parthenonis Zverinecensis, Typis Universitatis Jagiellonicae, provisore Ignatio Stelcel, 20 cm., 36, [3] ss.

Treść: jak w poz. 2.

[cz. 2] Catalogus [...], [3] ss.

Treść: jak w poz. 12.

Oprawa: jak w poz. 5 .

Sygn.: KUL-V 10446/1883.

E. -, L. - , Z. -

15. [cz. 1] Directorium [...] pro Anno Domini bissextili MDCCCLXXXIV [1884], Cracoviae 1884, sumptibus Parthe- 
nonis Zverinecensis, Typis Universitatis Jagellonicae, provisore Ignatio Stelcel, 20 cm., 36, [3] ss.

Treść: jak w poz. 2.

[cz. 2] Catalogus [...], [3] ss.

Treść: jak w poz. 12.

Uwagi: notatki.

Oprawa: jak w poz. 5 .

Sygn.: KUL-V 10446/1884.

E. - , L. - , Z. -

16. [cz. 1] Directorium divini officii secundum ritum Sacri ac Canonici Parthenonis Canonissarum Ord. Praemonstratensis in Zwierzyniec accommodatum pro Anno Domini post bissextilem primum MDCCCLXXXV [1885], Cracoviae 1885, sumptibus Parthenonis Zverinecensis, Typis Universitatis Jagellonicae, provisore Ignatio Stelcel, 19 cm., 37, [3] ss.

Treść: jak w poz. 2.

[cz. 2] Catalogus [...], [3] ss.

Treść: jak w poz. 2 .

Uwagi: zmiania tytułu kalendarza w stosunku do poz. 4.

Oprawa: jak w poz. 2.

Sygn.: KUL-V 10446/1885.

E. -, L. -, Z. -

17. [cz. 1] Directorium [...] pro Anno Domini bissextili MDCCCLXXXVIII [1888], Cracoviae 1888, sumptibus Parthenonis Zverinecensis, Typis Universitatis Jagellonicae, provisore A. M. Kostarkiewicz, 20 cm., 39, [2] ss. ss.

Treść: jak w poz. 2.

[cz. 2] Catalogus [...], [2] ss.

Treść: jak w poz. 5 .

Oprawa: jak w poz. 2.

Sygn.: KUL-V 10446/1888.

E. cz. 4, t. I, s. 311 , L. - Z. -

18. [cz. 1] Directorium [...] pro Anno Domini MDCCCXCI [1891] post bissextilem tertio, Cracoviae 1891, sumptibus Parthenonis Zverinecensis, Typis Universitatis Jagellonicae, provisore A. M. Koster- kiewicz, 23 cm., 43, [4] ss.

Treść: jak w poz. 2.

[cz. 2] Catalogus [...], [4] ss.

Treść: jak w poz. 12.

Oprawa: brak.

Sygn.: KUL-V 10446/1891.

E.,- L. - , Z.

19. [cz. 1] Directorium [...] pro Anno Domini MDCCCLXCII [1892] bissextili, Cracoviae 1892, sumptibus Parthenonis Zverinecensis, Typis Universitatis Jagellonicae, provisore A. M. Kosterkiewicz, 20 cm., 42, [4] ss.

Treść: jak w poz. 2.

[cz. 2] Catalogus [...], [4] ss.

Treść: jak w poz. 12, w tym również w Królestwie Polskim.

Oprawa: jak w poz. 2.

Sygn.: KUL-V 10446/1892.

E. - L. - , Z. -

20. [cz. 1] Directorium [...] pro Anno Domini MDCCCXCVI [1896] bissextili, Cracoviae 1896, sumptibus Parthenonis Zverinecensis, Typis Universitatis Jagellonicae, provisore A. M. Kosterkiewicz, 22 cm., 43, [4] ss.

Treść: jak w poz. 2.

[cz. 2] Catalogus [...], [4] ss.

Treść: jak w poz. 12.

Oprawa: jak w poz. 2.

Sygn.: KUL-V 10446/1896.

E. -, L. - , Z. -

21. [cz. 1] Directorium [...] pro Anno Domini MDCCCXCIX [1899] post bissextilem tertio, Cracoviae 1898, sumptibus Parthenonis Zverinecensis, Typis Universitatis Jagellonicae, provisore Josepho Filipowski, $19 \mathrm{~cm} ., 48 \mathrm{ss}$.

Treść: jak w poz. 2.

[cz. 2] Catalogus [...], s. 45-48.

Treść: jak w poz. 12.

Oprawa: jak w poz. 2, brak tylnej okładki.

Sygn.: KUL-V 10446/1899.

E. -, L. -, Z. - 
22. [cz. 1] Directorium [...] pro Anno Domini MCMXIV [1914] [...], Cracoviae 1914, sumptibus Parthenonis Zverinecensis, Typis Universitatis Jagellonicae, provisore Josepho Filipowski, 19 cm., 51 ss.

Treść: jak w poz. 2.

[cz. 2] Catalogus [...], s. 49-51.

Treść: jak w poz. 12, bez wykazu zmarłych.

Oprawa: jak w poz. 2.

Sygn.: KUL-V 10446/1914.

E. -, L. - , Z. -

\section{URSZULANKI UNII RZYMSKIEJ}

Unia Rzymska Zakonu Świętej Urszuli (Unio Romana Ordinis Sanctae Ursulae-OSU).

Urszulanki wywodzą się z założonego przez św. Anielę Merici w 1535 r. we Włoszech Towarzystwa św. Urszuli. Do Polski siostry przybyły w 1857 r. Pierwszymi ośrodkami były Poznań i Gniezno. Kulturkampf doprowadził do przeniesienia się sióstr do zaboru austriackiego. Autonomiczne domy zakonu utworzyły Unię Urszulanek Polskich (1920 r.) a następnie przystąpiły do Unii Rzymskiej (1935 r.) tworząc prowincję.

1. [cz. 2] Katalog Zgromadzenia SS. Urszulanek Polskich z roku 1933 na 1934, Kraków 1933, [b.w.], Drukarnia „Powściągliwość i Praca”, 22 cm., 61 ss., [1] k.

Treść: władze Zakonu, skład osobowy poszczególnych domów, statystyki, wykaz sióstr zmarłych, indeksy.

Uwagi: jęz. polski, na stronie tyt. i okładce herb Zakonu.

Oprawa: papier wydaw., napis jak na str. tyt.

Sygn.: KUL-V-17580/1933/34.

E. - , L. - , Z. -

2. Sygn.: KUL-V-1329/1938/39 -

\section{SŁUŻEBNICZKI STAROWIEJSKIE}

Zgromadzenie Sióstr Służebniczek Najświętszej Maryi Panny Niepokalanie Poczętej (Congregatio Sororum Servularum Beatae Mariae Virginis Immaculatae Conceptae).

Zgromadzenie powstało dzięki bł. Edmundowi Bojanowskiemu, który powołał je do życia w 1850 r. (zatwierdzone w roku 1930). Sytuacja w zaborach spowodowała, iż uległo ono podziałowi na 4 samoistne zgromadzenia. Służebniczki Starowiejskie, których działalność objęła jedynie ziemie zaboru austriackiego uzyskały autonomię w 1866 r. Dopiero w okresie międzywojennym rozprzestrzeniły się na teren II Rzeczypospolitej.

1. [cz. 2] Katalog Zgromadzenia Sióstr Służebniczek Najświętszej Marii Panny Niepokalanie Poczętej na rok 1939, Stara Wieś 1939, nakładem Zgromadzenia SS. Służebniczek Najśw. Marii Panny Niepokalanie Poczętej, Drukarnia Tow. Św. Michała Arch., 20 cm., 88 ss.

Treść: kalendarium, władze Zgromadzenia, domy Zgromadzenia w poszczególnych diecezjach (ze składem osobowym) wraz z prowadzonymi zakładami, wykaz sióstr zmarłych, indeksy.

Uwagi: jęz. polski.

Oprawa: papier wydaw., napis jak na str. tyt.

Sygn.: KUL-V-10341/1939.

E. -, L. - , Z. brak. 
THE CATALOGUE OF DIRECTORIES AND SCHEMATISMS OF THE FEMALE AND MALE RELIGIOUS ORDERS FROM THE AREA OF HISTORICAL LANDS OF THE POLISH REPUBLIC IN THE YEARS 1690-2008 IN THE COLLECTION OF THE LIBRARY OF THE THE JOHN PAUL II CATHOLIC UNIVERSITY OF LUBLIN

\begin{abstract}
Summary
Repeatedly raised demands for the need to draw up the lists of directories (liturgical calendars) and schematisms became an incentive to produce a catalogue of directories and schematisms of male and female religious orders existing in the territory of the Polish Republic. This work is based on part of a collection of these kinds of printed documents stored in the University Library KUL and covering the years 1690-2008. Its size is estimated to be around 600 titles, which places it among the largest collections of this type in academic libraries in Poland.

The entire bibliographic material was divided into two parts, the first of which includes male religious orders and congregations and the other female religious orders and congregations. Titles are listed chronologically according to administrative units which were part of various religious orders. A short description of religious orders includes mainly administrative divisions, which facilitates the identification of individual printed documents.

The Catalogue ... was preceded by an introduction, in which attempts were made to introduce general characteristics of the presented part of the collection: its internal structure, size, and various elements of bibliographic description.
\end{abstract}

